UNIVERSIDADE DE SÃO PAULO

FACULDADE DE FILOSOFIA, LETRAS E CIÊNCIAS HUMANAS

ANDRÉIA LOPES DA COSTA

As Possibilidades de Relacionamento entre

Capitalismo e a Economia Islâmica a partir da perspectiva de Muhammad Baqir Assadr 


\section{As Possibilidades de Relacionamento entre Capitalismo e a Economia Islâmica a partir da perspectiva de Muhammad Baqir Assadr}

Tese apresentada na Faculdade de Filosofia, Letras e Ciências Humanas da Universidade de São Paulo para a obtenção do título de Doutor em História.

Área de Concentração: História Econômica

Orientador: Prof. Dr. Jorge Luis da Silva Grespan

São Paulo 
AUTORIZO A REPRODUÇÃO E DIVULGAÇÃO TOTAL OU PARCIAL DESTE TRABALHO, POR QUQALQUER MEIO CONVENCIONAL OU ELETRÔNICO, PARA FINS DE ESTUDO E PESQUISA, DESDE QUE CITADA A FONTE.

COSTA, Andréia Lopes.

Tese ( Doutorado- Programa de Pós-Graduação em História. Área de Concentração: História Econômica)- Faculdade de Filosofia, Letras e Ciências Humanas da Universidade de São Paulo.

1. Economia Islâmica. 2. Capitalismo.3.Finanças Islâmicas. 4. Pensamento econômico islâmico. 


\section{FOLHA DE APROVAÇÃO}

Andréia Lopes da Costa

\section{As Possibilidades de Relacionamento entre Capitalismo e a Econômica Islâmica a partir da perspectiva de Muhammad Baqir Assadr}

Tese de Doutorado apresentada ao Departamento de História Econômica da Faculdade de Filosofia, Letras e Ciências Humanas da Universidade de São Paulo, sob orientação do Professor Doutor Jorge da Silva Grespan do Programa de Pós Graduação em História, para obtenção do título de Doutor.

Aprovado em:

\section{Banca Examinadora}

Prof. Dr.

Instituição: Assinatura:

Prof. Dr.

Instituição: Assinatura:

Prof. Dr.

Instituição: Assinatura:

Prof. Dr.

Instituição: Assinatura:

Prof. Dr.

Instituição: Assinatura: 



\section{DEDICATÓRIA}

Dedico esta pesquisa a minha família e amigos que com amor, paciência, compreensão e carinho ao longo destes anos tem estado ao meu lado. 


\section{AGRADECIMENTOS}

Minha gratidão a todos os professores, que na condição de verdadeiros mestres, colaboraram de maneira efetiva com a elaboração deste trabalho:

Ao Prof. Dr. Jorge Grespan, por me socorrer num momento em que mais ninguém acreditava neste tema a ser pesquisado.

Ao amigo de longa data Renatho Costa, que me fornece uma co-orientação fundamental, oferecendo sugestões pertinentes e sábias.

Aos amigos Fábio Metzger, Anna Martino Covelli, Luciana Garcia e Marcos Toyanks, pelo debate continuo, pela amizade e incentivo.

Um agradecimento especial ao Sheik Rodrigo Jalloul, que possibilita fazendo uma intermediação a viagem ao Irã. Sem isso a pesquisa não seria possível.

Aos colegas de trabalho e colegas de doutorado, e também aos alunos, que através dos debates contínuos e questionamentos, nos levam ao grande desenvolvimento pessoal.

Ao CNPq, pelo suporte financeiro.

A todos os funcionários do Departamento de História e da FFLCH, e todas as pessoas, que dê algum modo, nos auxiliaram na concretização de um grande sonho. 


\section{RESUMO}

Essa pesquisa procura mostrar as possibilidades de relacionamento entre a economia islâmica e o capitalismo, a partir de um de seus pensadores contemporâneos, Aiatolá Muhammad Baqir Assadr, iraquiano que desenvolveu pesquisas nas áreas de jurisprudência islâmica, economia e bancária.

Em seus trabalhos, como Iqtsaduna e A Banca Livre de Juros, procuramos explorar os princípios e sua filosofia para o desenvolvimento de um modelo que atendesse as necessidades da população muçulmana.

$\mathrm{Na}$ primeira parte de nossa pesquisa, procuramos levantar a biografia do autor, assim como seu contexto histórico, com o intuito de compreender as razões de suas críticas aos modelos capitalista e socialista.

Num segundo momento, tendo em mente o cenário em que vivia Assadr, foram analisadas suas principais obras na área econômica, onde buscamos compreender sua proposta para um modelo econômico islâmico, que serviu como base para o pensamento moderno.

$\mathrm{Na}$ parte final desta pesquisa procuramos debater o pensamento econômico dentro do contexto internacional, mostramos também a adaptação da lei islâmica, que pode ser restritiva para o sistema capitalista internacional e seu posicionamento liberal, mas também, buscamos refletir a criação de sistema capitalista islâmico, já que ao que parece, temos diversas faces do sistema econômico islâmico. 


\begin{abstract}
This research aims to show the possibilities of relationship between Islamic economics and capitalism, from one of his contemporary thinkers, Ayatollah Muhammad Baqir Sadr. Iraqi who developed research in the areas of Islamic jurisprudence, economics and banking.

In his works, as Iqtsaduna and The Interest Free Banking, we try to explore the principles and philosophy to develop a model that would meet the needs of the Muslim population.

In the first part of our research, we try to raise the author's biography as well as its historical context in order to understand the reasons for their criticism of the capitalist and socialist models.

Secondly, bearing in mind the scene in which he lived Sadr, was considered his major works, in the economic area, where we try to understand his proposal for an Islamic economic model, which served as the basis for modern thought.

In the final part of this research seek to discuss economic thinking within the international context, we also show the adaptation of Islamic law, which can be restrictive for international capitalist system and its liberal position, but also seek to reflect the creation of Islamic capitalist system, as that it seems we have the various aspects of Islamic economic system.
\end{abstract}


LISTA DE TABELAS

Tabela1 - Planejamento Islâmico Financeiro 


\section{LISTA DE FIGURAS}

$\begin{array}{ll}\text { Figura 1- Operações bancárias no Islã } & 113\end{array}$

$\begin{array}{ll}\text { Figura 2- Representação de Venda } & 160\end{array}$

Figura 3- Contratação de Serviços 163

$\begin{array}{ll}\text { Figura 4-Contratação de Serviços } & 164\end{array}$

Figura 5- Sistema Moderno de Relacionamento Islâmico 235 
Tabela de transliteração das letras árabes em letras latinas ${ }^{1}$

\begin{tabular}{|c|c|}
\hline b & ب \\
\hline$t$ & 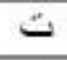 \\
\hline$\underline{t}$ & $\dot{H}$ \\
\hline $\mathrm{i}$ & I \\
\hline h & $z$ \\
\hline$\underline{h}$ & $\tau$ \\
\hline d & $j$ \\
\hline d & j \\
\hline $\mathrm{r}$ & 3 \\
\hline$z$ & 2 \\
\hline$s$ & س \\
\hline Š & b \\
\hline$S$ & ص \\
\hline $\mathrm{d}$ & ضن \\
\hline$t$ & $b$ \\
\hline$z$ & ط \\
\hline ' & E \\
\hline$\dot{g}$ & $\varepsilon$ \\
\hline $\mathrm{f}$ & i \\
\hline$q$ & 3 \\
\hline $\mathrm{k}$ & st \\
\hline 1 & $J$ \\
\hline $\mathrm{m}$ & ? \\
\hline $\mathrm{n}$ & ن ن \\
\hline $\mathrm{h}$ & $\circ$ \\
\hline w & 9 \\
\hline$y-\overline{1}$ & ي \\
\hline $\bar{a}$ & 1 \\
\hline , & c \\
\hline
\end{tabular}

${ }^{1}$ Seguimos Safa Jubran, 2004, alterando somente d por z. 


\section{GLOSSÁRIO $^{2}$}

\begin{tabular}{|c|c|c|c|}
\hline Palavras em Àrabe & Transliteração & $\begin{array}{c}\text { Tradução em } \\
\text { Português }\end{array}$ & $\begin{array}{c}\text { Transliteração } \\
\text { efetuada nas } \\
\text { obras em inglês }\end{array}$ \\
\hline 1. شريعة & šari'ah & $\begin{array}{l}\text { código de lei } \\
\text { islâmica }\end{array}$ & sharia \\
\hline زَكَاة & zakāt & tributo islâmico & zakat \\
\hline 3. التكافل & altakāful & seguro islâmico & altakaful \\
\hline 4. الربا & alrabō & juros fixos (usura) & alraba \\
\hline 5. الغرر & algarar & risco & algharar \\
\hline فقه . & fiqh & $\begin{array}{l}\text { jurisprudência } \\
\text { islâmica }\end{array}$ & Fiqh \\
\hline 7. الحديث & alhadīt & tradição & alhadith \\
\hline 8. إجماع & ijmā & consenso & ijma \\
\hline 9. قياس & qīāṣ & $\begin{array}{l}\text { dedução por } \\
\text { analogia }\end{array}$ & qyias \\
\hline اجتهاد .10 & ijtihād & $\begin{array}{l}\text { esforço de } \\
\text { reflexão }\end{array}$ & ijtihad \\
\hline 11. حَرَام & harām & ilícito & haram \\
\hline حلال .12 & halāl & permitido & halal \\
\hline مضاربة .13 & muḍārbat & $\begin{array}{l}\text { parceria islâmica } \\
\text { entre investidor e } \\
\text { empresário }\end{array}$ & mudaraba \\
\hline المضارب .14 & almuḍārib & investidor & almudarib \\
\hline الإجارة .15 & alijāarat & $\begin{array}{l}\text { contrato para dar } \\
\text { usufruto por } \\
\text { consideração em } \\
\text { um montante }\end{array}$ & alijarat \\
\hline المشاركة .16 & almušărakat & $\begin{array}{l}\text { empresa mista ou } \\
\text { estrutura de } \\
\text { parceria com o } \\
\text { lucro / perda de } \\
\text { partilha }\end{array}$ & almusharakah \\
\hline 17. هيلا & $\mathrm{h} \bar{\imath} \mathrm{l} \bar{a}$ & & Hila \\
\hline الوكالة .18 & alūakōalat & $\begin{array}{l}\text { agência (empresa } \\
\text { de investimento) }\end{array}$ & alwakala \\
\hline 19. يكتا & $\imath \mathrm{kt} \bar{a}$ & $\begin{array}{l}\text { taxa da terra } \\
\text { (feudo) }\end{array}$ & Iqtá \\
\hline الوكيل .20 & alūakūl & intermediário & alwakil \\
\hline الخلافة .21 & alhilāfat & gerente & alkhilafah \\
\hline 22. هيما & $\mathrm{h} \bar{\imath} \mathrm{m} \bar{a}$ & & himá \\
\hline
\end{tabular}

\footnotetext{
${ }^{2}$ Não foi possível fazer a transliteração de todas as palavras do vocabulário financeiro islâmico, já que tínhamos o texto base de nosso autor, mas utilizamos diversos materiais para compor esta pesquisa, portanto algumas permaneceram com a transliteração feita para os livros em inglês.
} 


\begin{tabular}{|c|c|c|c|}
\hline 23. يكتا & $\bar{\imath} \mathrm{kt} \bar{a}$ & $\begin{array}{l}\text { taxa da terra } \\
\text { (feudo) }\end{array}$ & Iqtá \\
\hline الظاهر .24 & alzāhir & minerais visíveis & Alzahir \\
\hline الباطن .25 & albātin & minerais invisíveis & albátin \\
\hline الصلح .26 & alsulh & $\begin{array}{l}\text { terra adquirida sob } \\
\text { acordo }\end{array}$ & Alsulh \\
\hline و الي عمرو .27 & wal' 'amru & $\begin{array}{l}\text { líder (chefe de } \\
\text { Estado) }\end{array}$ & walyyul' amr \\
\hline الدوحة .28 & aldawahah & terra conquistada & ada'wah \\
\hline التوحيد .29 & altawh̄̄d & & Tawhid \\
\hline 30. & & ato obrigatório & fardul kifayyah \\
\hline الآخر .31 & alāhira & vida eterna & Alakhira \\
\hline 32. الوكيل & alūakì & intermediário & Alwakil \\
\hline الخلافة .33 & alhilāfat & gerente & Alkhilafah \\
\hline 34. & & riquezas da terra & $\begin{array}{l}\text { al mubahatul } \\
\text { ammah }\end{array}$ \\
\hline الظاهر .35 & alzāhir & minerais visíveis & Alzahir \\
\hline 36. الباطن & albātin & minerais invisíveis & albátin \\
\hline والي عمرو .37 & wal $\bar{l}$ 'amru & $\begin{array}{l}\text { líder (chefe de } \\
\text { Estado) }\end{array}$ & walyyul' amr \\
\hline الدوحة .38 & aldawahah & terra conquistada & ada'wah \\
\hline 39. & & ato obrigatório & fardul kifayyah \\
\hline 40. الآخر & alāhira & vida eterna & Alakhira \\
\hline جعالة .41 & ju'ālah & $\begin{array}{l}\text { distribuição de } \\
\text { riqueza }\end{array}$ & ju'alah \\
\hline أجرة .42. & uharah & pagamento & Ujarah \\
\hline وكيل .43 & waqīl & $\begin{array}{l}\text { representação, } \\
\text { intermediação }\end{array}$ & Wakil \\
\hline 44. & & ato obrigatório & fardul kifayyah \\
\hline الآخر .45 & alāhira & vida eterna & alakhira \\
\hline جعالة .46 & ju'ālah & $\begin{array}{l}\text { distribuição de } \\
\text { riqueza }\end{array}$ & ju'alah \\
\hline أجرة .47 & uharah & pagamento & ujarah \\
\hline 48. & & ato obrigatório & fardul kifayyah \\
\hline الآخر .49 & alāhira & vida eterna & alakhira \\
\hline جعالة .50 & ju'ālah & $\begin{array}{l}\text { distribuição de } \\
\text { riqueza }\end{array}$ & ju'alah \\
\hline أجرة .51 & uharah & pagamento & ujarah \\
\hline 52. & & ato obrigatório & fardul kifayyah \\
\hline الآخر .53 & alāhira & vida eterna & alakhira \\
\hline استصناع .54 & istisnāh & $\begin{array}{l}\text { contrato de } \\
\text { fabricação }\end{array}$ & istisna’ \\
\hline استجر ار .55 & istihrārr & $\begin{array}{l}\text { contrato de } \\
\text { suprimento }\end{array}$ & istijrar \\
\hline إسر اف .56. & isrāf & $\begin{array}{l}\text { extravagancia, } \\
\text { desperdício }\end{array}$ & israf \\
\hline إقالة .57 & iqūalah & $\begin{array}{l}\text { cancelamento do } \\
\text { contrato }\end{array}$ & iqala \\
\hline
\end{tabular}




\begin{tabular}{|c|c|c|c|}
\hline حسبة .58 & hisbah & $\begin{array}{l}\text { regulação de } \\
\text { mercado }\end{array}$ & hisba \\
\hline حوالة .59 & hawālah & $\begin{array}{l}\text { transferência da } \\
\text { dívida }\end{array}$ & hawala \\
\hline غرر .60 & garar & $\begin{array}{l}\text { ambiguidade } \\
\text { contratual }\end{array}$ & gharar \\
\hline فاسد .61 & fāsid & não viável & fasid \\
\hline باطل .62 & bāțil & invalido & batil \\
\hline 63. استصناع & istisnāah & $\begin{array}{l}\text { contrato de } \\
\text { fabricação }\end{array}$ & istisna' \\
\hline 64.64 استجر ار & istihrārr & $\begin{array}{l}\text { contrato de } \\
\text { suprimento }\end{array}$ & istijrar \\
\hline
\end{tabular}




\section{SUMÁRIO}

INTRODUÇÃO

CAPÍTULO 1 - BREVE HISTÓRIA DO PENSAMENTO ECONÔMICO ISLÂMICO

1 A Evolução do pensamento econômico islâmico 26

1.1 Ensinamentos econômicos do Corão 28

$1.2 \mathrm{O}$ pensamento islâmico econômico contemporâneo 32

1.3 Vida e Obra de Muhammad Baqir Assadr 36

1.4 Inserção Histórica $\quad 42$

$\begin{array}{ll}1.5 \text { Movimento Sadrista } & 47\end{array}$

CAPÍTULO 2 - A ECONOMIA ISLÂMICA SEGUNDO ASSADR

2.1 Introdução $\quad 50$

2.2 A doutrina econômica e o Islã 51

2.3 Descoberta operacional da doutrina $\quad 52$

$\begin{array}{ll}2.4 \text { Estrutura geral } & 57\end{array}$

$\begin{array}{ll}2.5 \text { Natureza integrativa da economia islâmica } & 60\end{array}$

2.6 A religião pode materializar os interesses socais $\quad 62$

2.7 Economia Islâmica não é uma ciência 64

2.8 O problema econômico a luz do Islã 65

2.9 Distribuição de riqueza para o Islã $\quad 67$

2.10 Embasamento Teórico da Distribuição pré-produção 74

2.11 Distribuição pós-produção $\quad 77$

2.12 O papel do risco $\quad 81$

2.13 A Teoria da Produção $\quad 82$

2.14 Perspectiva islâmica entre a relação de Produção e Circulação $\quad 87$

2.15 O Papel do Estado na Economia $\quad 89$

2.16 O sistema bancário livre de juros 93

2.16.1 Um novo modelo bancário 93

2.16.2 Estrutura da Banca Livre de Juros 98

2.16.2.1 Depositantes e Investidores 101

2.16.3 Bancos no Ambiente Islâmico. 111

2.17 As Críticas de Assadr ao Marxismo e ao Capitalismo 114 
2.17.1 Componentes básicos da doutrina marxista

2.17.2 O Materialismo histórico como fator único

2.17.3 O Materialismo histórico à luz da filosofia

2.17.4 Desenvolvimento de forças produtivas e o marxismo

2.17.5 Ideologia e marxismo

2.17.6 Filosofia e marxismo

2.17.7 Ciência e marxismo

2.17.8 Os fatores físicos e o Marxismo

2.17.9 O valor do trabalho 126

2.17.10 Assadr sobre o comunismo primitivo 127

2.17.11 A escravidão 129

2.17.12 Sobre a sociedade feudal

2.17.13 Sobre o levante de uma sociedade capitalista

2.17.15 As características mais importantes do capitalismo na visão de Assadr

2.17.16 Economia capitalista e sua natureza

2.17.17 O capitalismo Doutrinário 138

2.17.18 A liberdade capitalista

2.17.19 A base de um novo modelo

CAPÍTULO 3 - RELAÇÕES ECONÔMICAS INTERNACIONAIS NO ISLÃ

3.1. Introdução

3.2 A Ética Islâmica e seus princípios

3.3 A Lei Econômica no Islã e sua regulamentação 150

3.4 Contratos na lei Comercial Islâmica 155

3.4.1 Classificação dos contratos 158

3.5 A Lei Islâmica Internacional 166

3.5.1 Relações econômicas internacionais no Islã 169

3.5.1.1 Justiça e benevolência no contrato internacional da distribuição de $\quad 170$ riqueza

3.5.1.2 Amanah (Confiança)

3.5.1.3 Justiça no Islã 174

3.5.1.4 Igualdade 177

$\begin{array}{ll}3.6 \text { A justiça econômica internacional } & 178\end{array}$ 
3.6.1 Regras para o comércio internacional

180

3.6.2 O Estado Islâmico e suas funções no mercado 183

$\begin{array}{ll}3.7 \text { Regras do comércio } & 189\end{array}$

3.7.1 Acesso ao mercado 190

$\begin{array}{ll}3.7 .2 \text { A proteção da moralidade pública } & 190\end{array}$

3.7.3 Mercado "halal" 192

$\begin{array}{ll}\text { 3.7.4 Política Anticompetição } & 194\end{array}$

3.8 A Ordem Monetária no Islã 198

3.8.1 A visão islâmica do papel-moeda e do dinheiro 201

3.9 Direcionamento financeiro 203

3.9.1 Crédito bancário 207

3.9.2 Comércio Internacional e Câmbio 210

3.9.3 Necessidade de um sistema monetário justo 211

3.9.4 Monopólio do dinheiro e o liberalismo 211

3.9.5 Interferência no mercado 212

3.10 Beneficios e Desvantagens do Padrão-Ouro 214

3.10.1 Uso do Padrão Ouro na Atualidade 216

3.11 Dinar como experiência islâmica $\quad 217$

3.12 Áreas de livre comércio e cooperação internacional no Islã 219

3.12.1 A lei islâmica e as preocupações com o desenvolvimento e cooperação $\quad 224$

3.13 A área de liberdade para Assadr 231

3.14 A Política externa islâmica 233

CONCLUSÕES $\quad 236$

BIBLIOGRAFIA $\quad 240$

$\begin{array}{ll}\text { ANEXOS } & 248\end{array}$ 


\title{
INTRODUÇÃO
}

\author{
"Fisicamente, habitamos um espaço, mas, \\ sentimentalmente, somos habitados por uma memória."
}

José Saramago

religião tem se apresentado como uma fonte de solução para os problemas do homem, que procura aplicar, na área econômica, a formulação de uma nova ética ${ }^{3}$. Nas áreas do comércio, gerenciamento ou contabilidade, têm sido elaborados estudos entre religião e atividades econômicas. Aqui, procuramos estudar o Islã, que pretende criar um sistema completo para a vida do homem, sendo que este abarcará o social, o espiritual e o econômico, fazendo assim uma ligação entre a vida terrena e Deus. O desejo deste sistema complexo é construir um tecido social no qual estejam firmados os valores éticos e princípios revelados aos homens para o direcionamento de sua vida.

Neste sistema social, a área econômica tem tido um reavivamento nas últimas décadas, porém ainda se encontra em estágio preliminar de desenvolvimento. Mas já apresenta, em sua base, valores considerados necessários para guiar e regular a vida econômica, com o intuito de atingir o objetivo da justiça social e sustentar o crescimento econômico nos países islâmicos.

O sistema econômico islâmico é baseado no Corão e na Sunna e sua preocupação central é atingir a prosperidade do homem, abarcando o desenvolvimento e crescimento de sua personalidade. Este modelo econômico incita que o gerenciamento sagaz e eficiente dos recursos é possível apenas quando o comportamento total do homem está dentro do quadro ético e moral do Islã. Orienta ainda que a sociedade pode ser construída apenas quando os aspectos materiais e espirituais da atividade humana são consolidados juntos.

A fundação da economia islâmica esta baseada nos princípios da justiça, honra, irmandade, oportunidades iguais perante o sistema, emprego adequado e segurança social. De fato, a justiça e a segurança social formam a base do sistema, sendo que a

\footnotetext{
${ }^{3} \mathrm{Na}$ visão dos pesquisadores da área teológica, como Leonardo Boff, Hugo Assmann e Franz J. Hinkelammert é necessário que se volte a fazer uma ligação entre a economia e a teologia, podendo assim trazer à tona uma questão da ética e moral que não se encontra dentro do sistema capitalista, além de trazer à tona uma mediação na idolatria do consumo encontrada no mercado. ASSMANN, H. HINKELAMMERT, Franz. A Idolatria do Mercado: Ensaio sobre a Economia e Teologia. São Paulo: Vozes, 1989 p. 9-18.
} 
questão da justiça dentro do sistema econômico compreende a questão de manter o respeito aos seres humanos dentro de seus direitos como cidadãos.

O modelo econômico islâmico busca resolver a questão da exploração através de um sistema mais ético, através das leis de Deus, interpretando a vida do homem na Terra como um teste, já que haverá uma prestação de contas e o sucesso na vida eterna dependerá da atuação nesta vida.

O Islã defende que esta vida deve ser conduzida por circunstâncias justas e que os recursos devem ser distribuídos de forma justa para uma boa qualidade de vida. Oportunidade igualitária e assistência social aos desabilitados na sociedade é o mínimo requerido pelo governo islâmico. Esse modelo busca focar na distribuição de recursos dando força ao Estado Islâmico, para que este possa agir de acordo com as leis corânicas.

A literatura a respeito da Economia Islâmica data do primeiro período do Islã, mas é realmente dada atenção ao fenômeno do século XX. Inicia-se na década de 30 e trabalhos mais especializados surgem na década de 40. Esse movimento é estimulado pela crise econômica naquele período e a crescente exposição das doutrinas socialistas aos intelectuais muçulmanos. Além disso, a independência dos países muçulmanos e o crescimento dos movimentos islâmicos também levantaram atenção para a aplicação dos ensinamentos e para as práticas das ações dos novos estados, inclusive a atenção aos aspectos fiscais.

Por um lado, os princípios econômicos do Islã foram largamente discutidos e analisados por estudiosos muçulmanos à luz do Corão e pela vasta herança intelectual deixada por seus predecessores. Por outro lado, o modelo econômico dominante capitalista e o socialismo foram criticados.

Estes dois sistemas que emergiam, no entanto, pareciam instáveis e injustos para a solução dos problemas econômicos do homem e os intelectuais muçulmanos de fato buscaram trabalhar de forma objetiva neste período contemporâneo. Com isso, a economia islâmica tem vivido um renascimento, porém, ainda está em um estágio preliminar de desenvolvimento em contraste com a economia convencional que se apresenta bem desenvolvida.

Nesta tese, procuramos apresentar o modelo econômico islâmico a partir da visão de Muhammad Baqir Assadr, autor iraquiano. Sua pesquisa sobre a economia islâmica é considerada o modelo mais completo a respeito do tema, servindo assim como base para a criação do modelo islâmico. 
Com a revolução islâmica no Irã, temos uma retomada da religião como uma fonte para a solução da existência humana, na visão dos estudiosos do Islã, incluindo aqui as atividades econômicas e o desenvolvimento humano.

O Islã força seu papel dentro do sistema político e econômico e isto parece, muitas vezes, ser um fenômeno desconfortável para o sistema internacional. Sendo assim, é necessário que se aceite e se aprenda a ter um ponto de vista positivo, analisando sua contribuição ao sistema moderno econômico. Para promover o desenvolvimento e a justiça econômica, as relações internacionais devem ser compreendidas dentro do contexto histórico, ao invés do uso particular de uma definição de comércio.

A economia islâmica concorda com a visão de que as regras para a economia e o desenvolvimento internacional devem ser ajustadas e aplicadas na justiça assim como os princípios igualitários ${ }^{4}$, aceitos por toda comunidade, devem ser livres de pressões politicas e estratégicas injustificadas. Substantivamente, a economia islâmica possui um ponto de vista diferente em alguns temas, o que pode gerar certo conflito com os preceitos da moderna economia internacional.

Esse modelo estabelece certos limites aos meios e métodos para o comércio e a criação de riqueza. Alguns destes são aceitos por outros grupos culturais, porém, alguns não são, como por exemplo a riba, o papel-moeda e o crédito bancário. Adicionalmente, alguns aspectos econômicos que são ignorados pela moderna lei internacional tomam sérias considerações na lei islâmica, tal como a proibição de determinados alimentos e os jogos de azar, assim como alguns aspectos éticos na área de negócios e investimentos ${ }^{5}$.

Estas diferenças abrem a oportunidade de discussão e interação no âmbito da economia política internacional, para que o sistema possa buscar a evolução que sirva a uma sociedade pluralista, rejeitando uma agenda que procura uma homogeneização global. As doutrinas islâmicas destacam a importância de valores éticos e morais, integrando todos estes dentro do sistema econômico, sendo que seus valores também são análogos à sociedade cristã, tais como confiança, irmandade, benevolência e compaixão ao próximo.

De fato, o desenvolvimento de uma economia islâmica pode contribuir para a busca de uma área negligenciada, já que o sistema capitalista não resolve o problema da

\footnotetext{
${ }^{4}$ Toda a base de regras da lei islâmica focam os princípios de justiça e equidade segundo a religião islâmica.

${ }^{5}$ Esses temas serão abordados nos capítulos II e III, no contexto internacional.
} 
pobreza, do subdesenvolvimento e do débito internacional. Esperamos que este trabalho possa contribuir e iniciar estudos, dentro do âmbito da economia islâmica e que as pesquisas se ampliem além do âmbito doméstico, podendo assim defender os direitos dos países islâmicos e levar sua contribuição para uma busca da justiça social na economia internacional.

Sua validade pode ser testada por sua consistência e compatibilidade em organizar outros aspectos da vida, além da sua capacidade de melhoria e crescimento da qualidade de vida humana. Indo mais longe, podemos afirmar que as instituições humanas, sem a referência de valores, passam a ser inconcebíveis. Aliás, a questão do cientificismo se mostra extremamente complicada para se defender, pois apoia-se exclusivamente na racionalidade, fazendo abstração de valores que têm trazido a visão de um horizonte triste para a humanidade.

Portanto, nesta tese, levamos à discussão um modelo econômico com base religiosa, não fazendo aqui questionamentos de valor deste modelo, mas o apresentamos como mais um modelo dentre os sistemas que possuímos agora, já que a economia islâmica cresce e, através da Banca Islâmica, se expande, não somente nas áreas de população muçulmanas, mas também como uma opção ao sistema capitalista tradicional.

Nesta pesquisa partimos do pressuposto de que há um entrelaçamento entre a economia e teologia que tem consequências bastante sérias para a maneira de se encarar e enfrentar muitos problemas. Isso foi o propósito que moveu esta pesquisa em todas as nossas reflexões teóricas.

Suspeitamos e levantamos, nesta tese, que a economia trabalha muitas vezes com pressupostos teológicos, afinal, ela nasce como teoria econômica recente através de muitos filósofos e teólogos que abordaram o tema. Aqui aplicamos a ideia ao comércio internacional, enfrentamos um sistema multicultural vasto, e a sobrevivência do sistema mundial está condicionada à cooperação e à compreensão entre as diferentes culturas e religiões.

A lei econômica internacional vem buscando se adaptar aos desafios apresentados. No entanto, os níveis de como e o quanto as crenças e valores culturais afetam os sistemas econômicos, socais e políticos são varíaveis.

Temos consciência de que dizer isso é algo inquietante a muitos economistas já que, como disciplina acadêmica - especialmente a orientação neoclássica - reluta em aceitar que precise de pressupostos valorativos, derivados da filosofia ou de expressos 
posicionamentos políticos ${ }^{6}$. Mas é impossível negar que os sistemas econômicos carregam uma ideologia a qual fornecem a base e objetivos, por um lado, e os axiomas e princípios por outro. Com isso, este sistema terá sua estrutura, a qual a sociedade utilizará no processo de produção e distribuição para atender as necessidades de sua população e obter lucratividade.

Nas intenções desta pesquisa não estava inserido um mergulho em profundidade na história do pensamento econômico, embora seja um caminho promissor. Mas, devido à questão de levantamento de material e tempo de pesquisa, apresentamos aqui um autor principal, procurando sempre articular suas ideias.

Pretendemos aqui descrever o pensamento econômico islâmico usando Muhmmad Baqir Assadr como referência, fazendo um debate, mesmo que não tão aprofundado sobre os autores deste período, trazendo a crítica contemporânea ao capitalismo, ao socialismo e ao comunismo, mostrando que as discussões eram políticas e muito importantes como referência para a população islâmica.

Na construção da economia islâmica, os pensadores acabaram criando um modelo de wellfare state, um modelo de capitalismo coordenado, por parte de um estado, que apresenta uma estrutura islâmica. Dentro deste capitalismo coordenado não há impossibilidade de um relacionamento entre os modelos, mas há sim um forte protecionismo religioso que iremos apresentar na última parte da pesquisa.

Procuramos nesta tese não incorrer nos erros passados realizados quando se tratava tanto de Oriente Médio quanto Ásia, mas procuramos descrever nosso autor e sua crença, e sua visão do capitalismo. Também destacamos a influência da colonização ocidental ao nosso autor, fazendo com que sua visão e também de outros autores do mundo islâmico ${ }^{7}$ acabem focando as teorias levantadas no ocidente através de criticas pesadas.

Levamos em consideração aqui que a nossa bibliografia é, em sua base, composta de traduções de textos do árabe e farsi, feitas para o inglês. Procuramos ser o mais precisos

\footnotetext{
${ }^{6}$ ASSMANN, H. HINKELAMMER, F. Idolatria do Mercado: Ensaio sobre Economia $e$ Teologia. Vozes: São Paulo, 1898, p.10.

${ }^{7}$ Colocamos aqui mundo islâmico, devido ao fato de vários autores da área de economia islâmica se encontrarem na Indonésia e Malásia, sendo ali um dos grandes centros de pesquisa da área. Estes também apresentam criticas ao capitalismo, seguindo visão similar dos autores do Irã, Iraque, Paquistão entre outros países.
} 
nas traduções, verificando com pesquisadores de Qom os conceitos e a tradução do artigo em farsi que usamos também como base para nossas conclusões.

Não realizamos exatamente aqui uma construção da história do xiismo - mesmo levando em consideração nos capítulos, parte da história da religião - mas apresentamos em si como essência da pesquisa a história de nosso autor e discutimos seu pensamento.

Os textos-base utilizados foram o livro de "Iqtsaduna" de nosso autor e sua pesquisa para o governo do Kuait, "A Banca Livre de Juros"8. Em alguns momentos também utilizamos suas pesquisa sobre jurisprudência, mas este material ecoa apenas para compreensão de seu pensamento.

Com o intuito de confirmar as hipóteses levantadas através da bibliografia base, realizamos uma visita técnica na Universidade de Qom, onde foram realizados questionários, debates com pesquisadores da área econômica e estudos da lei e da religião islâmica.

No primeiro capítulo, utilizamos métodos históricos para subsidiar nossa pesquisa. Partimos dos pressupostos de que a formação do autor no Iraque serve de base para seu pensamento. Procuramos não descrever a história do Islã e nem do Iraque, sendo que o subsidio não seria a base para as ideias de Assadr, pois acreditamos que o momento histórico, como instruído pelas entrevistas, seria a fonte da busca de uma economia islâmica.

Para a elaboração do segundo capítulo, fizemos uma análise das obras de Assadr para a área econômica e bancária. Procuramos levantar suas principais ideias e criticas a respeito da economia e do sistema bancário e, em alguns momentos, posicionamos Assadr frente a outros autores do sistema contemporâneo. Essa opção de analisar comparando outros foi escolhida para que seja melhor compreendido o pensamento islâmico econômico no período, mostrando assim o destaque que Assadr possui.

Tendo em vista que este trabalho pretende analisar a questão internacional, mostrou-se de fundamental importância a questão bancária, mostrando a base e a estrutura da teoria elaborada por Assadr. Contudo, não fizemos aqui um detalhamento de partes específicas, como por exemplo, cartas de crédito e outras partes, já que são apenas mencionadas e não são o enfoque principal de sua pesquisa.

\footnotetext{
${ }^{8} \mathrm{Ambas}$ as versões foram adquiridas do inglês para a pesquisa. Infelizmente, mesmo em visita ao Irã, não foram encontradas as versões em árabe no momento, o que impossibilitou que se pudesse fazer todas as transliterações o mais precisas possível usando o texto do autor.
} 
No terceiro capítulo, trabalhamos as nossas entrevistas, nas quais preferimos utilizar entrevistas não estruturadas, pois foi perceptível, na primeira parte da tese, que caberiam diferentes interpretações para o relacionamento entre o capitalismo e o modelo econômico islâmico. Como era perceptível, a diversidade das visões contribuiria muito para a nossa pesquisa. Cabe lembrar aqui que a perspectiva de conseguir ser atendida por pesquisadores no Islã parecia difícil, já que os estudiosos não costumam ser entrevistados por mulheres ocidentais não muçulmanas ${ }^{9}$. Foi necessária flexibilidade na conquista de informações.

Portanto, nossa pesquisa aqui se dá pelo método qualitativo, pelo fato de que esse processo, ou mesmo estudos de relacionamento entre modelos, cabem diversas particularidades, dependendo de momento histórico ou liderança política, ou seja, percepções individuais. Apesar da dificuldade que expomos aqui, o método qualitativo foi fundamental para nossa pesquisa.

$\mathrm{Na}$ escolha dos pesquisadores que poderíamos entrevistar, procuramos escolher os que poderiam nos fornecer uma visão global da economia islâmica e suas ideias de expansão e relacionamento com outros estados não islâmicos. Cabe aqui lembrar que pude entrevistar pesquisadores religiosos na Universidade de Qom, entre outras Universidades, porém os Aiatolás me negaram entrevistas, no argumento de que tinham suas agendas ocupadas ${ }^{10}$.

Com o intuito de comprovar a hipótese levantada, trabalhamos na transcrição das entrevistas e fizemos as citações na íntegra em nosso terceiro capítulo. Aqui criamos um debate entre as ideias do Islã para o Estado, para a lei islâmica internacional, a política externa e a prática expressa pelos pesquisadores, procurando mostrar se o discurso de nosso autor possui uma prática aplicável mais amplamente ou funcionaria como um discurso interno no Iraque apenas.

\footnotetext{
${ }^{9}$ A todo momento era dada ênfase de que a Universidade de Qom não havia recebido nem homem e nem mulher interessados nas pesquisas de Assadr para a área econômica, sendo que ali não havia em farsi nenhuma pesquisa relacionada à área internacional.

${ }^{10}$ Durante os meses de junho e julho de 2014, estive na Universidade de Qom, no Irã, como pesquisadora candidata ao doutorado, através do apoio da Al-Mustafa International University, que viabilizou todas as entrevistas. Os entrevistados para a pesquisa foram: Professor Dr. Majid Rezaei, Professor Dr. Seyed Hadi Arbabi, Professor Dr. Seyed Abbas Musaviyan, Professor Dr. Muhammad Javad Tavakoli, Professor Dr. Muhammad Ali Hajidehabadi, Professor Dr. Muhammad Ali Savadi, Professor Dr. Shahryar Shojaeipour, Professor Dr. Morteza Maddaahi, Professor Dr. Morteza Muhammadi, Professor Dr. Ali Hadavinia.
} 


\section{CAPÍTULO I}

"Havendo Deus, há só um Deus. Dele, desse Deus unico, é que teriam provindo as revelações que levaram ao judaísmo, ao cristianismo e ao islamismo. Ora, como essas revelações, quer no espírito quer na forma, não são iguais entre si (e deveriam sê-lo, uma vez que nasceram da mesma fonte), infere-se que Deus é histórico, que Deus é simples História. Por outras palavras: quando a História precisa de um Deus, fabrica-o."

José Saramago

\section{BREVE HISTÓRIA DO PENSAMENTO ECONÔMICO ISLÂMICO}

\section{A Evolução do Pensamento Econômico Islâmico}

A evolução do pensamento econômico islâmico pode ser traçada até o período do Profeta Maomé. Desde esse período, temas econômicos têm sido debatidos sob diferentes perspectivas por vários autores, no contexto de diferentes disciplinas em resposta à necessidade dos respectivos tempos na história islâmica.

No principio da Economia Islâmica, quatro diferentes dimensões de análises foram identificadas. Primeiramente, temas foram debatidos à luz do Corão, como por exemplo, discussões sobre a proibição da usura e o encorajamento de atividades econômicas para o bem estar do homem. Segundo: temas foram debatidos à luz da Fiqh, tendo como exemplo os aspectos legais da Mudaribah e Musharikah em grandes detalhes. Terceiro: temas econômicos têm sido discutidos por muçulmanos à luz do sistema de ética islâmico para desenvolvimento moral. Os trabalhos dos Ulemas, Sufis e filósofos muçulmanos e reformadores vieram sob esta categoria. Quarto: alguns bons trabalhos relacionados à economia têm sido escritos por estudiosos do Islã em resposta às necessidades do seu tempo enquanto atuavam em escritórios governamentais. Os trabalhos relacionados às finanças, receitas, gastos e taxas públicas estão sob esta categoria. 
Houve autores como Imam Gazzali ${ }^{11}$, Ibn Taimiyah ${ }^{12}$ e Ibn Khaldun ${ }^{13}$ que procuraram desenvolver trabalhos na área econômica. Suas atividades foram uma base clara para a filosofia ética e social do Islã. Seus trabalhos se basearam na sharia com o desejo de promover o interesse público. Os princípios gerais foram derivados do Corão e os detalhes e princípios necessários, do tempo do profeta.

O profeta viveu em um pequeno estado em Medina e suas políticas econômicas eram simples. Com suas conquistas, ocorreu a expansão do islamismo, levando assim seu modelo de ética a outras fronteiras. Com sua morte, seus sucessores foram obrigados a organizar seus pensamentos, compilando assim o Corão e a Sunna do profeta. Várias regras foram adotadas após mútua consultação e consensos (Ijma) dos companheiros do profeta. O impulso principal do consenso foram as politicas adotadas com base na Sharia e guiada pelo interesse publico.

Outras duas fontes se desenvolveram além do Corão e da Sunna: o consenso de opinião e o raciocínio lógico de especialistas na lei islâmica sobre o interesse público. Mais tarde, a sociedade se expande gradualmente tornando-se mais complexa, trazendo assim novos problemas de natureza pessoal, social, política e internacional. Cresceu assim a necessidade de se fazerem pesquisas para descobrir soluções para estes problemas à luz do Corão e dos hadith e então de desenvolveu a Fiqh. Os temas da Fiqh não ficaram confinados à ablução, jejum, hajj ou zakat, mas tentaram cobrir outros aspectos da sociedade, incluindo economia. Isso continuou por um longo período até o advento dos

\footnotetext{
${ }^{11}$ Imam Gazzali nasceu em 1058 d.C em Tus, onde hoje se encontra o Irã. Considerado um dos grandes teólogos e jurista da área islâmica, ele de dedica a estudar principalmente a ciência dos hadiths. Aos 34 anos ganha fama, mas decide viver afastado para um processo de purificação e elevação espiritual. Pertencia a escola Shafi'i de jurisprudência, mas também contribui para uma visão sistemática do Sufismo, dando espaço dentro do Islã tradicional. Influênciou os filósofos cristão medievais.

${ }^{12}$ Ibn Taimiyah nasceu em1236 em Harran e faleceu em Damasco. É considerado um teólogo muçulmano de grande importância, principalmente pela sua influência no salafismo. Viveu no período da queda do califado Abássida. Seus estudos na área econômica são estudados hoje oferencendo grande influência aos autores contemporâneos do pensamento islâmico econômico. ${ }^{13}$ Ibn Khaldun nasceu em 1332 e faleceu em 1406. Considerado um precursor da moderna historiografia. Seu principal trabalho é Muqaddimah, sendo que aqui aborda temas como economia e administração pública, resultado de sua atuação com os Sultões do período.
} 
Abássidas ${ }^{14}$, quando as questões econômicas foram de grande importância. Neste período, muitos livros foram escritos sobre temas econômicos, particularmente sobre politica financeira.

A história do pensamento econômico através de quatorze séculos tem sido dividida em vários estágios com alguns representantes de cada um destes estágios. $\mathrm{O}$ Corão e os Hadith, sendo fonte divina, não podem ser incluídos como um pensamento econômico, porque pensamento é um processo humano. No entanto, é necessário jogar luz sob os ensinamentos básicos para compreender os princípios que têm sido levados em consideração pelos pensadores muçulmanos enquanto discutimos os problemas econômicos através da história islâmica.

\subsection{Ensinamentos econômicos do Corão}

O Corão oferece uma série de valores, guias e regras que servem como a base para um desenvolvimento apropriado para o sistema econômico. Os valores positivos discutidos no Corão incluem: justiça, honestidade, moderação e bondade aos menos favorecidos, enquanto a injustiça, avareza, extravagância, miséria e acumulação são denominadas como valores negativos e encontradas em nossa sociedade.

No Corão, o comércio é permitido, porém identifica algumas práticas proibidas como a usura, má apropriação e jogatina. Existem mais de duzentos versos do Corão os quais, de uma forma ou de outra, estão relacionados à economia: incluem aqui o zakat, as mercadorias proibidas e permitidas ao consumo, sobre a riqueza, a propriedade privada, comércio, o crédito e o débito, a fraude, as associações e contratos etc. Existem cinco áreas do comportamento econômico que são proeminentemente mencionadas no Corão que incluem justiça e responsabilidade social, aquisição da riqueza, distribuição da riqueza, proteção dos menos favorecidos e regulação das transações através de contratos.

O Corão põe muita ênfase na manutenção da justiça na sociedade. Essa justiça ('Adl) deve ser colocada em todos os aspectos da vida, incluído os econômicos. Os que buscam as relações econômicas são exortados a agir de forma justa, com sinceridade,

\footnotetext{
${ }^{14}$ A dinástia começa com Abul Abbas em 750 d.C. e irá cair pelas mãos do governante mongol que captura Bagdá em 1258. Sua capital fora um importante centro de instrução e cultura durante o período de vigor deste Império.
} 
honestidade e o espirito de cooperação. Eles são enfatizados a providenciarem uma descrição justa de mercadorias envolvidas na transação e garantir um padrão próprio de medidas em que são usadas. Os que cometem atos de injustiça são obrigados a arrependerse. Eles são exortados que sua punição na vida aqui por diante será severa e até neste mundo terá que sofrer. Muitos atos proibidos no comércio e nas finanças são descritos como injustos, tais como a desonestidade, traição, fraude, má interpretação das coisas e roubo. A sociedade islâmica é responsável por manter a justiça tanto no nível individual quanto no coletivo.

As atividades econômicas direcionam os muçulmanos a aproveitarem plenamente as bênçãos de Deus. O Corão enfatiza repetidamente que todas as coisas no universo pertencem a Allá, sendo que Ele criou todas as coisas e permite ao homem explorá-las e usá-las para suas necessidades. No entanto, o homem deve distinguir entre as coisas dentro da lei e as coisas fora da lei. O Corão ordena que a riqueza devem ser adquirida dentro de meios legais e que os meios ilegais devem ser descartados por completo.

Esses meios ilegais são trabalhados com profundidade pelo Profeta e juristas islâmicos os têm elucidado em seus livros de leis. O Corão estabelece uma política de despesas mais ampla para uma distribuição justa de riqueza entre as várias seções da sociedade. O principal objetivo dos princípios corânicos de distribuição é evitar a concentração de riqueza nas mãos de poucos ${ }^{15}$. O Corão ordena repetidamente aos fiéis que dêem aos pobres e aos necessitados e aos seus parentes de acordo com suas necessidades ${ }^{16}$. Ainda declara que haverá uma recompensa por estes atos ${ }^{17}$ e também punição para os que não agem com generosidade ${ }^{18}$.

A distribuição e concentração da riqueza são reforçadas pelas leis da herança ${ }^{19}$, sendo que o Corão apresenta o desejo de que a riqueza permaneça em circulação, sendo

\footnotetext{
15 "E de quando exigimos o compromisso dos israelitas, ordenando-lhes: Não adoreis senão a Deus; tratai com benevolência vossos pais e parentes, os órfãos e os necessitados; falai ao próximo com doçura; observai a oração e pagai o zakat. Porém, vós renegastes desdenhosamente, salvo um pequeno número entre vós."'(Corão 2:83)

16 "Se fizerdes caridade abertamente, quão louvável será! Porém, se a fizerdes, dando aos pobres dissimuladamente, será preferível para vós, e isso vos absolverá de alguns dos vossos pecados, porque Deus está inteirado de tudo quanto fazeis". (Corão 2:271)

17 "Porém, àquele que dá (em caridade e é temente a Deus, E crê no melhor, Facilitaremos o caminho do conforto)." (Corão 92:5-7)

18 "O que foi que vos introduziu no tártaro? Responder-lhes-ão: Não nos contávamos entre os que oravam, Nem alimentávamos o necessitado..." (Corão 74: 42-44)

19 "E lhes enumeraremos as ações com pleno conhecimento, porque jamais estivemos ausentes. E a ponderação, nesse dia, será a equidade; aqueles cujas boas ações forem mais pesadas serão os
} 
também encorajada a moderação nos gastos ${ }^{20}$. De fato, a extravagância está ligada à corrupção $^{21}$ e a punição dada deve ser severa ${ }^{22}$.

De acordo com o Corão, a riqueza deve ser adquirida por se engajar em atividades socialmente benéficas, que tomam em conta as necessidades dos mais fracos dentro do sistema social. Por isso o Corão proíbe a usura que leva à exploração.

O Corão aborda que a cobrança da usura levará o servo à perda das bênçãos de Deus $^{23}$, colocando a usura no mesmo sentido de se apropriar da propriedade de outro ${ }^{24}$.

O Corão, para regular as atividades econômicas na sociedade, insiste que as transações devem ser governadas por regras para não haver disputas entre os fiéis,

bem-aventurados. E aqueles, cujas boas ações forem leves, serão desventurados, por haverem menosprezado os Nossos versículos. Temo-vos enraizado na terra, na qual vos proporcionamos subsistência. Quão pouco agradeceis! Criamo-vos e vos demos configuração, então dissemos aos anjos: Prostrais-vos ante Adão! E todos se prostraram, menos Lúcifer, que se recusou a ser dos prostrados. Perguntou-lhe (Deus): Que foi que te impediu de prostrar-te, embora tivéssemos ordenado? Respondeu: Sou superior a ele; a mim criaste do fogo, e a ele do barro". (Corão 4: 712)

20 "Não cerres a tua mão excessivamente, nem a abras completamente, porque te verás censurado, arruinado". (Corão 17:29) "Ó fiéis, em verdade, muitos rabinos e monges fraudam os bens dos demais e os desencaminham da senda de Deus. Quanto àqueles que entesouram o ouro e a prata, e não os empregam na causa de Deus, anuncia-lhes (ó Mohammad) um doloroso castigo. No dia em que tudo for fundido no fogo infernal e com isso forem estigmatizadas as suas frontes, os seus flancos e as suas espáduas, ser-lhes-á dito: eis o que entesourastes! Experimentai-o, pois!" (Corão 9:34-35)

21 "E de quando Moisés Nos implorou água para o seu povo, e lhe dissemos: Golpeia a rocha com o teu cajado! E de pronto brotaram dela doze mananciais, e cada grupo reconheceu o seu. Assim, comei e bebei da graça de Deus, e não cismeis na terra, causando corrupção." (Corão 2:60) "Lembrai-vos de que Ele vos designou sucessores do povo de Ad, e vos enraizou na terra, em cujas planuras ergueis palácios, e em cujas montanhas cavais moradias. Recordai-vos das mercês de Deus para convosco e não causeis flagelo, nem corrupção na terra”. (Corão 7:74)

22 'Não vos posteis em caminho algum, obstruindo a senda de Deus e ameaçando quem n'Ele crê, esforçando-vos em fazê-la tortuosa. Recordai-vos de quando éreis uns poucos e Ele vos multiplicou, e reparai qual foi o destino dos depravados" (Corão 7:86) "Em troca, aqueles que violam o compromisso com Deus, depois de o haverem constituído, que desunem o que Deus ordenou fosse unido e causam corrupção na terra, sobre eles pesará a maldição e obterão a pior morada." (Corão 13:25)

23 "Os fiéis que praticarem o bem, observarem a oração e pagarem o zakat, terão a sua recompensa no Senhor e não serão presas do temor, nem se atribularão. Ó fiéis, temei a Deus e abandonai o que ainda vos resta da usura, se sois crentes! Mas, se tal acatardes, esperai a hostilidade de Deus e do Seu Mensageiro; porém, se vos arrependerdes, reavereis apenas o vosso capital. Não defraudeis e não sereis defraudados. Se vosso devedor se achar em situação precária, concedeilhe uma moratória; mas, se o perdoardes, será preferível para vós, se quereis saber." (Corão 2:277280)

24 "E por praticarem a usura, sendo que isso thes estava proibido, e por usurparem os bens alheios com falsas pretensões. E preparamos para os incrédulos, dentre eles, um doloroso castigo." (Corão $4: 161)$ 
evitando assim também as injustiças ${ }^{25}$. Os contratos, portanto, devem ser sempre assinados e com testemunhas ${ }^{26}$. O Corão comanda os crentes a cumprirem suas promessas $^{27}$ e $\operatorname{contratos}^{28}$ e dá ênfase de que é um dever pelo qual eles deverão prestar contas no Dia do Julgamento ${ }^{29}$. Honrar as obrigações é uma marca dos crentes; por outro

25 "Que o devedor dite, e que tema a Deus, seu Senhor, e nada omita dele (o contrato). Porém, se o devedor for insensato, ou inapto, ou estiver incapacitado a ditar, que seu procurador dite fielmente, por ele. Chamai duas testemunhas masculinas de vossa preferência, a fim de que, se uma delas se esquecer, a outra recordará. Que as testemunhas não se neguem, quando forem requisitadas. Não desdenheis documentar a dívida, seja pequena ou grande, até ao seu vencimento. Este proceder é o mais equitativo aos olhos de Deus, o mais válido para o testemunho e o mais adequado para evitar dúvidas. Tratando-se de comércio determinado, feito de mão em mão, não incorrereis em falta se não o documentardes. Apelai para testemunhas quando mercadejardes, e que o escriba e as testemunhas não sejam coagidos; se os coagirdes, cometereis delito. Temei a Deus e Ele vos instruirá, porque é Onisciente.” (Corão 2:282)

26 "Ó fiéis, quando contrairdes uma dívida por tempo fixo, documentai-a; e que um escriba, na vossa presença, ponha-a fielmente por escrito; que nenhum escriba se negue a escrever, como Deus lhe ensinou. Que o devedor dite, e que tema a Deus, seu Senhor, e nada omita dele (o contrato). Porém, se o devedor for insensato, ou inapto, ou estiver incapacitado a ditar, que seu procurador dite fielmente, por ele. Chamai duas testemunhas masculinas de vossa preferência, a fim de que, se uma delas se esquecer, a outra recordará. Que as testemunhas não se neguem, quando forem requisitadas. Não desdenheis documentar a dívida, seja pequena ou grande, até ao seu vencimento. Este proceder é o mais equitativo aos olhos de Deus, o mais válido para o testemunho e o mais adequado para evitar dúvidas. Tratando-se de comércio determinado, feito de mão em mão, não incorrereis em falta se não o documentardes. Apelai para testemunhas quando mercadejardes, e que o escriba e as testemunhas não sejam coagidos; se os coagirdes, cometereis delito. Temei a Deus e Ele vos instruirá, porque é Onisciente. (Corão 2:282).

27 "Deus cumpriu a Sua promessa quanto, com a Sua anuência, aniquilastes os incrédulos, até que ccomeçastes a vacilar e disputar acerca da ordem(186) e a desobedecestes, apesar de Deus vos Ter mostrado tudo o que aneláveis. Uma parte de vós ambicionava a vida terrena, enquanto a outra aspirava à futura. Então, Deus vos desviou dos vossos inimigos, para provar-vos; porém, Ele vos indultou, porque é Agraciante para com os fiéis." (Corão 6:152); "Cumpri o pacto com Deus, se houverdes feito, e não perjureis, depois de haverdes jurado solenemente, uma vez que haveis tomado Deus por garantia, porque Deus sabe tudo quanto fazeis."(Corão 16:91); "Não disponhais do patrimônio do órfão senão da melhor forma, até que ele chegue à puberdade, e cumpri o convencionado, porque o convencionado será reivindicado. (Corão 17:34)

28 "Ó fiéis, cumpri com as vossas obrigações. Foi-vos permitido alimentar-vos de reses, exceto o que vos é anunciado agora; está-vos vedada a caça, sempre que estiverdes consagrados à peregrinação. Sabei que Deus ordena o que Lhe apraz. (Corão 5:1); "Exceto para os seus cônjuges ou cativas - nisso não serão reprovados. (Corão 23:6)

29 "Não disponhais do patrimônio do órfão senão da melhor forma, até que ele chegue à puberdade, e cumpri o convencionado, porque o convencionado será reivindicado.” (Corão 17:34) 
lado, a violação é proibida. Aos obedientes é ordenado que paguem os débitos ${ }^{30}$, deem plena medida ${ }^{31}$, devolvam o que é confiada a $\operatorname{eles}^{32}$ e evitem as fraudes e trapaças.

O pensamento economico islâmico não se desenvolverá tanto no período medieval, tendo obras relevantes, mas não expressivas como no período contemporâneo. Podemos citar aqui apenas alguns autores como Ibn Tammyiah, Ibn Khaldun, entre outros, mas essas pesquisas eram realizadas mais por filósofos, assim como no Ocidente.

\subsection{O pensamento islâmico econômico contemporâneo}

Uma pesquisa sobre o pensamento islâmico contemporâneo mostra que há um acordo entre os economistas muçulmanos e estudiosos sobre a base filosófica do sistema econômico islâmico ${ }^{33}$. A maioria, senão todos os escritores, mencionam o tawhid (unicidade), khilafah (vice-gerência), 'ibadah (adoração) e takaful (cooperação) como os

30 "Entre os adeptos do Livro, há alguns a quem podes confiar um quintal de ouro, que te devolverão intacto; também há os que, se lhes confiares um só dinar, não te restituirão, a menos que a isso os obrigues. Isto, porque dizem: Nada devemos aos iletrados. E forjam mentiras acerca de Deus, conscientemente. (Corão 3:75)

31 "Não disponhais do patrimônio do órfão senão da melhor forma possível, até que chegue á puberdade; sede leais na medida e no peso - jamais destinamos a ninguém carga maios á que pode suportar. Quando sentenciardes, sede justos, ainda que se trate de um parente carnal, e cumpri os vossos compromissos para com Deus. Eis aquilo que Ele vos prescreve, para que mediteis."( Corão 6:152); "E aos medianias enviamos seu irmão Xuaib, que lhes disse: Ó povo meu, adorai a Deus, porque não tereis outra divindade além d'Ele! Já vos chegou uma evidência do vosso Senhor! Sede leais, na medida e no peso! Não defraudeis o próximo e não causeis corrupção na terra, depois de ela haver sido pacificada! Isso será melhor para vós, se sois fiéis."(Corão 7:85); "E enviamos ao povo de Madian seu irmão Xuaib (Jetro), o qual disse: Ó povo meu, adorai a Deus porque não tereis outra divindade além d'Ele; e não altereis a medida nem o peso, porque vejo a prosperidade em vós; porém temo por vós o castigo do dia abrangedor. Ó povo meu, disponde da medida e do peso com equidade; não defraudeis os humanos em seus bens e não pratiqueis a devassidão na terra, como corruptores (Corão 11:84-85); "E quanto instituirdes a medida, fazei-o corretamente; pesai na balança justa, porque isto é mais vantajoso e de melhor consequência (Corão 17:35); "E em verdade, teu Senhor é o Poderoso, o Misericordiosíssimo." (Corão 26:181)

32 "Se estiverdes em viagem e não encontrardes um escriba, deixareis um penhor resgatável; quando vos confiardes reciprocamente, saiba, quem tiver recebido o depósito, que deverá restituílo, temendo a Deus, seu Senhor. Não vos negueis a prestar testemunho; saiba, pois, quem o negar, que seu coração é nocivo. Deus sabe o que fazeis." (Corão 2:283); "Deus manda restituir a seu dono o que vos está confiado; quando julgardes vossos semelhantes, fazei-o equidade. Quão excelente é isso a que Deus vos exorta! Ele é Oniouvinte, Onividente." (Corão 4:58)

${ }^{33}$ SIDDIQI, Nejatullah. The Economic Enterprise in Islam. Paquistão: Islamic Publications Ltd, 1988, p.195. 
pilares filosóficos do sistema econômico islâmico. Não há disputa referente à obrigação do estabelecimento do zakat e a proibição da riba.

Há obviamente diferenças nas interpretações, não só pelo resultado de sua educação, experiências e circunstâncias de cada um, mas também devido à possibilidade de diferenças teóricas dentro desta disciplina. As discussões sobre as diferenças não deveriam ser evitadas pelo medo da quebra de unidade no desenvolvimento da economia islâmica, mas devem ser vistas como uma força, flexibilidade e realismo da economia islâmica. De qualquer forma, para a estrutura e criação de uma economia realmente islâmica, é necessária a visão do tawhid ${ }^{34}$.

Segundo Haneef (1995, p.45) podemos colocar os seguintes economistas na lista de pensadores do sistema econômico na contemporaneidade: Muhammad Abdul Mannan $^{35}$, Muhammad Nejatullah Siddiqi ${ }^{36}$, Syed Nawab Haider Naqvi ${ }^{37}$, Monzer Kahf $^{38}$, Sayyid Mahmud Taleghani ${ }^{39}$ e nosso autor estudado Muhammad Baqir Assadr.

\footnotetext{
${ }^{34}$ Tecnicamente significa que algo pertence a Deus, e a ninguém mais. Crer no tawhid é fundamental no Islã, e o valor do sistema islâmico é baseado nesta crença. Isso afeta o comportamento econômico dos muçulmanos de diversas formas.

35 Nasceu em Bangladesh em 1938. Depois de receber seu mestrado em Economia da Universidade de Rajshahi em 1960, trabalha no departamento de economia no governo do Paquistão. Em 1970, o autor vai aos Estados Unidos da América, onde se matricula na Universidade do Estado de Michigan para um Mestrado em Economia e em 1973 ele obtém o doutorado por esta mesma Universidade. Mannan nutria interesse por muitas áreas como educação econômica, desenvolvimento econômico, relações industriais e finanças. Depois de seu doutorado, atua como professor em diversas universidades. Com sua experiência, o autor atua como economista no Banco de Desenvolvimento Islâmico em Jeddah. Nos utilizamos aqui do seu principal livro: Islamic Economics: Theory and Practice.

${ }^{36}$ Nasceu em Gorakhpur na Índia em 1931, sendo que sua formação de base é realizada no Jama'at-i Islamia e depois na Universidade Islâmica de Aligarh. Siddiqi escreveu sobre economia islâmica quando não havia quase nenhuma literatura. Sua carreira acadêmica irá começar na Universidade de Aligarh e mais tarde se direciona para a King Abdul Aziz em Jedá onde será um dos pioneiros na criação do Centro para pesquisa em economia islâmica. Ali, o autor escreve diversos livros sobre economia islâmica. Sua pesquisa se concentrava na questão do dinheiro, banco e temas da área financeira.

${ }^{37}$ Naqvi nasceu no Paquistão em 1935, porém seus estudos foram realizados nos EUA, em Yale e Princeton. Destas destacadas instituições, o autor vai lecionar em países como Noruega, Turquia e Alemanha antes de retornar ao Paquistão, em 1975. Ele assume, em 1979, a diretoria do Instituto para Desenvolvimento Econômico. Naqvi cita extensivamente o Corão em suas pesquisas. Diferente de Assadr e Taleghani, o autor prefere não citar os Imãs.

${ }^{38}$ Monzer Kahf é um professor sírio-americano, que obtem seu $\mathrm{PhD}$ na Universidade de Utah, sendo considerado um dos autores mais estudados na área de economia islâmica. Atualmente, o professor é também pesquisador sênior no Islamic Development Bank, com sede na Árabia Saudita e tem atuado em algumas universidades americanas.

39 Mahmud Taleghani nasceu no Irã, considerado um reformador e grande defensor da democracia. Foi contemporâneo de Khomeini, e atuou contra o movimento secularista de Reza Pahlavi. Recebe grande influência da exegese corânica em seus trabalhos, fazendo sempre
} 
Os três primeiros citados são economistas por formação e os outros, juristas principalmente atuando dentro do sistema islâmico. Cada um destes escreveu um trabalho que é tomado como referência pelos estudiosos na atualidade. Poderíamos colocar outros pesquisadores, mas para Haneef (1981, p.5), estes estudiosos têm sido aceitos dentro do ambiente acadêmico como economistas ou pensadores do sistema econômico por seus contemporâneos e seu trabalho tem sido frequentemente utilizado como referência por outros.

Os tópicos cobertos por estes autores são: o zakat e a taxação dentro do sistema islâmico, a abolição da riba, teoria e ética econômica islâmica, o consumo, seguros, a cooperação entre os países islâmicos e o desenvolvimento econômico. Como terceiro pilar do Islã, o Zakat é muito estudado e também comparado com os sistemas judaico e cristão. Os muçulmanos da contemporaneidade optam por um sistema unificado.

Os estudos sobre a abolição da riba e a eliminação dos juros no final do século XX procuram tratar dos temas financeiros contemporâneos como as operações bancárias e a política monetária e fiscal. Ou seja, os estudiosos buscaram incorporar temas mais modernos na visão islâmica, procurando mostrar como ainda são relevantes para a vida contemporânea os ensinos corânicos.

O banco livre de juros era um conceito novo e não levado a sério por muitos economistas até metade do século XX, já que o modelo convencional em si é uma invenção do século XIX e só atrai maior atenção ao mundo islâmico na metade do século XX. Assadr discutem as operações bancárias a partir de uma perspectiva islâmica e fornecem informações que serão utilizadas na criação do modelo atual, mais prático, e utilizado também no Ocidente.

A abolição da riba focada na segunda metade do século XX e neste período é abordada dentro dos principais temas contemporâneos, como as operações de instituições bancárias e financeiras, sobre a política fiscal e monetária. A questão aqui é que era necessário endereçar as questões da modernidade e provar que o Islã ainda é relevante a este período.

O fator comum apresentado por estes autores do período contemporâneo é que seria possível para a banca islâmica operar em uma base de divisão de lucros e perdas ${ }^{40}$.

fundamentações com o Corão.Favoravel ao movimento de nacionalização da Indústria Petroleira no Irã. Recebeu sua educação formal em Qom onde obtém ali certificação de competência em .

${ }^{40}$ RODNEY, W. EL-ASHKER, A. Islamic Economics: A Short History. London: BRILL, 2006, p.366. 
Neste período, se expandem os contratos de parceria e os investidores que desejavam investir mantinham seus depósitos em demanda.

Os bancos islâmicos nascem de forma a conquistar espaço na década de 60, fazendo com que comecem a se tornar um mercado opcional para quem desejava fugir do sistema financeiro tradicional e suas crises.

Com o estabelecimento dos bancos islâmicos, a questão de uma política monetária foi levantada. Naquele momento se questionava se era possível uma política monetária dentro da lei islâmica e como isso iria se diferenciar de políticas não islâmicas. Houve um consenso de que esta política monetária deveria ser orientada ideologicamente, diferente de outras políticas monetárias ${ }^{41}$.

Na questão das funções dos estados islâmicos, estas são muito parecidas com os modelos de estados tradicionais, cabendo aqui a responsabilidade de promover e defender a ideologia islâmica. A questão dos impostos será o ponto de discussão maior, sendo que haverá autores que colocam como responsabilidade maior a questão da distribuição de renda e autores que defendem menor intervenção do Estado nos assuntos de distribuição da riqueza, dando maior força à ideia de autorregulamentação do mercado. O consenso é de que este estado deverá manter a estabilidade do valor da moeda, manter a taxa de emprego, o crescimento econômico e deve promover a justiça ${ }^{42}$.

Os autores desenvolveram um modelo de economia que refletisse um equilíbrio ou harmonia social que fosse comparado ao tempo do Profeta. O comportamento do consumidor é um tema preocupante para o Islã, sendo que alguns autores criam a ideia de um mapa de consumo, para guiar o consumo de acordo com as leis do Islã.

Dos debates sobre o zakat, a questão que pesou neste período contemporâneo foi se o estado islâmico moderno poderia ou não impor outros impostos, além do zakat; e como o Estado deveria gerenciar a distribuição desta, sendo que este imposto se mostra ainda insuficiente para cobrir as necessidades da sociedade.

\footnotetext{
${ }^{41}$ Idem, p.368.

${ }^{42}$ Idem. p.369.
} 


\subsection{Vida e Obra de Muhammad Baqir Assadr}

Sayyed Mohammad Baqir Assadr possui ancestralidade que pode ser traçada ao Profeta Maomé, através do sétimo Imam Musa al-Kadim ${ }^{43}$. Considerado pelos xiitas como um mártir ${ }^{44}$, perde seu pai ainda muito jovem sendo assim criado pelo irmão mais velho e por sua mãe. Seu pai - Sayyed Haydar Assadr - deixa a família em uma situação lamentável financeiramente e, em 1945, sua família se muda para a cidade de Najaf, no Iraque, onde Assadr passa o resto de sua vida.

O autor é descrito como uma criança prodígio, devido ao fato de que ainda muito jovem era capaz de levantar questionamentos sobre textos que são estudados no curso avançado no seminário islâmico ${ }^{45}$. Todo o período de seus estudos não estendeu mais do que dezoito anos, sendo que com apenas doze era capaz de ministrar aulas de história islâmica. Para o pesquisador Haneef (1995, p.110), era mais do que natural que Assadr decidisse por seguir este caminho - de um intelectual xiita - visto que seu pai também fora um destacado pensador nesta área.

Aos vinte e cinco anos de idade, Assadr completa seus estudos na Hawza e, logo após um ano, começa a lecionar jurisprudência islâmica ${ }^{46}$ no Bahth Al-Krarej, e é nesta

\footnotetext{
${ }^{43}$ Musa ibn Já' far al-Kadhim, nascido em Abawa- entre Meca e Medina- é considerado o sétimo imam no grupo dos Xiitas Duodécimo.

${ }^{44}$ Mártir é descrito como alguém que morre por sua fé religiosa, muitas vezes pelo simples fato de professar determinada religião, ou por agir coerentemente com esta fé religiosa. Atualmente a palavra tem ganhado sentido mais amplo, sendo usada para pessoas que defendem e morrem por uma ideologia, pela crença na liberdade, independência ou autonomia de um povo. Dentro da História Cristã, no livro do Novo Testamento iremos ver pessoas que morreram por sua fé na "palavra de Deus" e preferiram entregar suas vidas a renegar a Jesus Cristo. No cristianismo o batismo de sangue é aquele que morre antes mesmo de ser batizado. Os primeiros a serem batizados com sangue seriam as crianças mortas pelos soldados de Herodes, os quais ele enviou para matar as crianças nascidas em Belém no período de nascimento de Jesus Cristo. Estas crianças são consideradas as primeiras a serem batizadas pelo sangue e são reconhecidas pela Igreja Católica. Fonte: Dicio. Disponível em <http://www.dicio.com.br/martir>. Acesso em 01 out.2015.

${ }^{45}$ Citando seminário islâmico aqui estamos falando da Hawza, os locais onde os xiitas eram colocados ainda muito jovens para estudar a história islâmica, o Corão e as leis pertinentes ao sistema islâmico.

${ }^{46}$ Jurisprudência islâmica é constituída pelas decisões dos acadêmicos islâmicos que dirigem as vidas dos muçulmanos. Há quatro escolas sunitas, as quais são nomeadas a partir de um jurista clássico que são a Shafi'i (Malásia), Hanafi (Egito), Maliki (África Ocidental), Hanbali (Arábia). Essas quatro escolas sunitas guardam raízes e origem na única escola xiita Jaferi, estabelecida pelo Imã Jaafer Ibn Mohammad em meados do século VI. NASSER, Salem H. "Seria a sharia a única fonte do direito islâmico nos países árabes?" IN: Diálogo América do Sul-Países Árabes. Brasília: Funagipri, 2005.
} 
própria instituição que se torna um proeminente membro da comunidade xiita iraquiana. Alguns de seus estudantes tornam-se membros destacados como al-Hakim e al-Haidari.

Quando Assadr começou a trabalhar como professor, se casou com sua prima, filha do Ayatullah Al-Odhma Sayyed Sadr Addin Assadr e deste matrimônio nasceram cinco filhos, um menino e quatro meninas. Os esposos de suas filhas também foram torturados com Assadr no período de grandes problemas entre os xiitas e o Partido Baath. Seu filho ainda segue seus passos e procura dar continuidade ao seu trabalho atualmente, divulgando suas obras e ensino. Segundo biografia publicada pelo Centro Islâmico do Brasil:

“(..) seu destaque pode ser confirmado pelos múltiplos papeis que desempenhou em prol do Islã, como: ter lecionado no Bahth Al-Kharej por mais de vinte anos, ter auxiliado intelectualmente o grupo de líderes religiosos da Revista Islâmica iraquiana Al-Adhwah, ter prestado assistência às faculdades de Ensino Religioso, ter construído uma nova instituição para os Sábios Xiitas conhecida mundialmente a Marja’yya al-Maudu'iyah, ter sido autor de livros considerados nos campos da Economia, Lógica, Jurisprudência, Princípios da Crença e outros, ter sido autor de valiosos artigos político-intelectuais em defesa da República Islâmica do Irã.” (AL-KHAZRAJI, 2006, p.13)

Podemos perceber a prtir de todos os anos de trabalho e luta de Assadr pela construção de uma República Islâmica, que seu papel no ativismo político xiita do Iraque entre os anos 1958 e 1980 e suas crenças o levaram a desenvolver trabalhos e pesquisas dentro da área política, econômica, jurídica e religiosa.

Durante o período em que escrevia as mensagens do $J_{a m a}{ }^{\prime} t^{47}$ para rádio e também para o jornal Ad-Adhwah, Assadr publicou seu primeiro estudo filosófico chamado Falsafatuna (Nossa Filosofia), uma crítica ao comunismo, na qual argumentava que este modelo tinha muitas falhas e carências para que fosse considerada a verdade final para a humanidade. Para o autor, o comunismo não poderia ser a resposta para os problemas da humanidade, pois suas bases hipotéticas eram falsas. O objetivo de Assadr neste Partido era organizar os muçulmanos devotados para a formação de um Estado Islâmico, porém não há certeza sobre sua criação:

"Embora a origem exata do partido Daw'a ainda seja desconhecida, existem três teorias sobre quando foi fundado e por quem. A primeira é que ela foi idealizada por três homens, Talib al-Ria, Sayyid Mahdi alHakim, e uma pessoa desconhecida em 14 de julho de 1958. A segunda

\footnotetext{
${ }^{47}$ Grupo de Ulemás pro-Khomeini que residiam no Iraque e procuravam com o movimento islâmico a constituição de um Estado Islâmico dentro dos preceitos do xiismo.
} 
teoria é que foi formada em 12 de outubro de 1957, de acordo com um documento do partido Daw'a e verificada por meio de uma de suas figuras principais, Muhammad Saleh al-Adib. A última teoria é que ele foi estabelecido em Najaf 12 de outubro de 1957, por oito clérigos na casa da autoridade xiita líder, Sayyid Mubsin al-Hakim. Meses mais tarde, em Karbala, uma segunda reunião foi realizada com a participação de membros das mesmas uma primeira junto com algum novo membro para incluir Muhammad Baqir al-Sadr que foi creditado com a nomeação do partido do Daw'a Partido Islâmico." (HOLLINGER, 2009, p.25)

O partido parecia restaurar o Islã na vida dos muçulmanos, através da aplicação da sharia e com isso foram estabelecidos dois estágios. O primeiro era transformar a vida dos muçulmanos através da mudança da comunidade, trazendo o Islã à vida diária. A segunda fase seria a aplicação na política e assim eles precisariam travar uma luta armada contra os inimigos. Esse ideal, de fato, é atingido por Khomeini com a Revolução Iraniana em 1979 que sempre teve o apoio dos xiitas iraquianos. Porém, no Iraque, Assadr consegue apenas a aplicação da primeira fase deste processo, que durou 22 anos, agindo nos bastidores. Mas esse início foi significativo, pois o movimento Sadristra ${ }^{48}$ perdura no Iraque até hoje.

Naquele período, o papel de Assadr no Partido foi muito importante, porém por um período de sua vida, os mestres da Hawza aconselharam-no a desistir de seu papel político no Partido e no jornal, já que seria prejudicial à sua liderança na Hawza, uma vez que no futuro ele poderia ser tornar um Grande Marje' 49 dos xiitas. E desde que sua nomeação dependia da aprovação de professores e dos eruditos da Instituição, a perspectiva de Assadr tornar-se o líder de todos os xiitas estava condicionado às suas atividades políticas, visto que muitas facções da Hawza eram críticas a seu ativismo. Sendo assim, foi questionado se as publicações para o jornal Ad-Adhwah realmente expressavam o ponto de vista do Jama'at.

\footnotetext{
${ }^{48} \mathrm{O}$ Movimento Sadristra é um movimento nacional baseado em um fundamentalismo islâmico que tem por liderança Muqtad Al-Sadr, considerado o Sadr III. Muqtada procura estabelecer as metas e filosofias de Muhammad Sadeq Assadr, que seguiu as linhas de seu mentor, Muhammad Baqir Assadr. Nas eleições em 2009, eles conseguem 43 dos 440 assentos disponíveis, chegando em terceiro lugar e se mostrando um movimento forte, atuando nas camadas mais pobres no Iraque.

${ }^{49} \mathrm{O}$ Marje atua como líder xiita e comumente é selecionado entre os eruditos destacados no Fiqh e no Usul Al-Fiqh e o candidato tem que provar capacidade no método socrático e pela publicação de suas opiniões legais.
} 
Com a saída de Assadr do jornal e do Partido $D a$ 'wah, limitou-se a uma vida para o ensino, porém manteve contato com o partido através de seus alunos:

\begin{abstract}
"Na década de 1960, Baqir era um proeminente mujtahid em Najaf e estava na linha para se tornar o Grande Marja no futuro, no entanto, devido ao seu envolvimento na política, sua nomeação estava em perigo. Assim, devido ao aumento da pressão do Marji'iyya, ele começou a se distanciar do partido. Muitos na Hawza sentiam que suas atividades políticas eram prejudiciais a ele e que sua retórica continuada nos editoriais publicados no Jornal mensal al-Adwa era prejudicialm aos membros da Hawza. Em 1961, Baqir al-Sadr desistiu do partido Dawa e de seu editorial al-Dawa. A partir de 1961-1968, Baqir al-Sadr se concentrou na Hawza, reformou o currículo e ajudou a estabelecer um colégio em Bagdá.”( HOLLINGER, 2009, p.27)
\end{abstract}

Com a mudança de enfoque, dirigindo a sua carreira para a Hawza, o autor decide trabalhar na mudança do currículo do curso, pois verifica que os alunos não eram tão regulares às aulas e estavam negligenciando. Assim, propõe um novo livro, já que os que possuíam não foram escritos para estudantes e não levavam em conta a capacidade do aluno em entender o islamismo.

Quando o Ba'ath toma um posicionamento sobre as forças comunistas dentro do Iraque, Assadr foca em seus problemas internos do partido, deixando os xiitas livres das interferências governamentais, o Partido $D a$ 'wah aumenta seu número de membros dentro das universidades e assim expande sua influência. Mas o Ba'ath tramaria depois de um tempo um plano para limitar o poder dos xiitas, pois percebia que Assadr era de grande influência no Iraque e sua primeira medida foi procurar romper com as atividades religiosas do grupo, como o fechamento de escolas, fechamento do jornal religioso, a expulsão de estudantes não iraquianos e uma lei para que os iraquianos frequentadores da Hawza se alistassem nas forças armadas ${ }^{50}$.

Todos os fatores citados fizeram o autor perceber que o Regime Ba'ath surpreendeu os religiosos xiitas, que eles estavam muito desorganizados e isso certamente poderia causar a ruína da comunidade no Iraque. Com isso, organizaram e mobilizaram

\footnotetext{
${ }^{50}$ No sítio eletrônico do Partido Islâmico Da’wah, é possível encontrar uma biografia de Assadr, pois como foi um dos membros criadores do Partido e um de seus mártires, Assadr possui uma biografia na parte de membros honoráveis e ali também encontraremos uma descrição da luta de Assadr contra o Regime Ba'ath e o seu desfecho. Disponível em $<$ http://www.islamicdawaparty.com/? module $=$ home $\&$ fname $=$ pastmembers.php\&active $=8>$. Acesso em 23jan.2013.
} 
protestos, com o intuíto de conseguir maior apoio das comunidades muçulmanas, porém, sem a intervenção no país, o avanço dos xiitas foi refreado com as medidas do governo e a Hawza foi lançada ao caos.

O Regime Ba'ath não desejava se opor ao líder dos xiitas e por um momento se refreou em tomar maiores medidas, mas logo atacou novamente o Da'wah sentenciando os homens suspeitos de oposição a cinco anos de prisão, bem como sentenciou outros à morte pela corte revolucionária. Com a sentença dos ‘sábios religiosos', respeitados pela comunidade, houve uma condenação pública. Porém, havia um temor de que mais religiosos fossem executados e Assadr emitiu um decreto proibindo os estudantes que aderissem a qualquer partido político. Nesse momento, ele foi chamado para um interrogatório e logo foi liberado. (AL-KHAZRAJI, 2006, p.21).

$\mathrm{Na}$ esperança de se proteger dos ataques políticos, o autor se refugiou na Hawza, pois sabia que como Grande Marje', poderia conseguir proteção. Neste momento, atuou auxiliando os estudos islâmicos, a pesquisa, escrevendo matérias (disciplinas), cuidando de assuntos junto aos sábios e ajudando o movimento islâmico em outras cidades. Através destes trabalhos, Assadr ficou reconhecido como o futuro Marje', porém, ele sabia que ainda não era o Marje' Supremo - autoridade que daria a ele o poder religioso e financeiro para realizar as mudanças que ele desejava. Com isso, Assadr publica um livro no qual ele mesmo se coloca como Marje', pois pensava que desta forma conseguiria certa imunidade, protegendo-se assim da perseguição governamental. Acreditava que sua vida seria poupada, visto que os grandes líderes não eram executados. Com a publicação de seu livro Al-Fatawa Al-Wadiha, os membros do Partido e seus admiradores se referiam a ele como Grande Marje', porém isso não impediu que o governo fosse mais duro em suas decisões contra Assadr.

Um dos pontos mais importantes de sua carreira são suas publicações: estas conseguiram um bom alcance e até hoje seus trabalhos são mencionados por estudiosos como pilares para as crenças islâmicas. Com a publicação de Iqtsaduna (Nossa Economia), o governo do Kuait o comissiona para fazer um trabalho de gerenciamento da riqueza petrolífera conforme os preceitos do Islamismo. Através deste trabalho, o autor consegue lançar mão da estrutura básica para o desenvolvimento do moderno sistema bancário, esssa pesquisa intitulada "Usury-Free Banking Islam", ainda é considerado uma de suas pesquisas mais importantes. 
Seus trabalhos procuravam reviver a tradição islâmica para os muçulmanos, principalmente a juventude que ele acreditava estar se afastando do puro islã. Por isso, o autor trabalha para a melhoria do currículo dos seminários, desenvolvendo uma nova estrutura para o ensino dos seminaristas e com essa mudança se esperava a purificação pela palavra do Profeta em todos os aspectos da vida.

Com essa mudança, o autor pretendia espalhar sua filosofia política conhecida como Wilayat Al-Umma - a governança pelo povo - que defendia uma visão moderna para o Estado Islâmico naquele período. Com todo seu conhecimento do Corão e também da jurisprudência islâmica, Assadr conseguiu desenvolver dois conceitos em relação à governança: o khilafat al-insan e shahadat al-anbiya. Com estes conceitos, o autor consegue demonstrar que o direito de governar pertence a toda a humanidade e explica também que esta obrigação dada por Deus aos homens é um avanço da interpretação na política islâmica.

Segundo Haneef (1995, p.110), a última década de sua vida foi marcada por constante perseguição por parte do Regime Ba'ath que estava no poder, no Iraque, visto que Assadr instigava e apoiava a revolta da população no Irã e pedia apoio para o desenvolvimento de um Estado Islâmico que garantiria os direitos políticos e étnicos de todos.

Quando Khomeini ${ }^{51}$ envia uma mensagem através de amigos para Assadr pedindo que permanecesse na Hawza e não partisse do Iraque para o Irã (apesar do assédio do governo), a mensagem é ouvida por milhares de pessoas que iniciam uma onda de manifestações em várias cidades iraquianas. Com isso, o governo começa uma forte repressão ${ }^{52}$ e desta vez Assadr e sua irmã são presos, levando multidões iradas a entrarem em conflito com a polícia, fazendo com que o governo o libertasse.

O governo o procurou novamente objetivando um acordo e alívio na pressão entre a liderança xiita e o Ba'ath, porém o autor se recusou a suavizar sua mensagem para a população, com isso todos sabiam que seu martírio era iminente e, em 31 de março de

\footnotetext{
${ }^{51}$ Assadr é preso em 1977, devido a sua popularidade é libertado. Mais tarde ele e sua irmã serão presos novamente, até o desfecho do com ua morte. Neste período sua irmã participava ativamente da militância político religiosa.

${ }^{52}$ Os documentos governamentais mostram que a Corte Revolucionária decretou 258 sentenças de morte em vinte e dois julgamentos.
} 
1980, o governo aprova uma lei que sentencia a todos do Partido Da'wah à morte. Tanto para os membros do passado quanto os do presente e de partidos aliados, a tal lei acabou com qualquer possibilidade de sua vida ser poupada. Hollinger $(2009$, p. 26) faz um relato:

\footnotetext{
“Após um dia na prisão Baqir em 1979, o Partido Dawa muda para a fase dois, levando a ação mais violenta e mortal. Al-Sadr ordenou operações militares contra os funcionários e órgãos de repressão do governo. Ele confirmou a necessidade de pegar em armas para o cumprimento deste objetivo. Em 30 de março, 1980, o Conselho do Comando Revolução (CCR) tornou ilegal ser um membro do Partido Dawa e qualquer violação seria passivel de punição com morte. Em Abril 1980, Baqir e sua irmã foram presos e executados sumariamente."
}

No dia oito de abril de 1980, Assadr e sua irmã são sentenciados à morte, sendo executados um dia depois da sentença. Nesta mesma data, os corpos são transportados para Najaf durante a noite e entregues a seu tio. Com medo da repressão, o Exército fecha as saídas da cidade com tanques e soldados, e o autor e sua irmã são enterrados em segredo, somente sendo transferidos de local em 2003 (AL-KHAZRAJI, 2006, p.35). É importante compreender o cenário iraquiano naquele momento para compreender todo o desenvolvimento da obra de Assadr, pois suas obras refletem a situação política e econômica do país.

\subsection{Inserção histórica}

Quando o califado do Islã se espalhou no século VIII, houve uma revolta que levou os Abássidas ao poder, fazendo da capital do Iraque o centro da civilização. Estes padronizaram a literatura, a arquitetura e a caligrafia. Estabeleceram escolas, livrarias, hospitais e asilos. O estudo da teologia e das leis foi considerado importante pela tradição sunita da escola de direito Hanafi, que foi fundada em Bagdá.

Por problemas internos, a posição do Califa foi enfraquecida e, no século XIII, os mongóis dominariam Bagdá, destruindo o sistema de irrigação e matando milhares, incluindo o último Califa Abássida, marcando assim o fim de Bagdá como centro da Civilização Islâmica. Esse califado cai pelas mãos dos mongóis que, com a morte de Abu Said, deixaria uma instabilidade tendo uma nova renovação com o Império Otomano.

Com as forças turcas derrotando os bizantinos, estabelece-se o Império Otomano em Anatólia, que se estendeu até a Europa, criando uma administração integrada para ser 
social, econômica e politicamente centralizada. O Iraque vive sob o Império Otomano em três províncias: Basra, Bagdá e Mossul, onde estavam concentrados os governos militares pelos pashas mamelucos, que gradualmente operavam com alguma independência do Sultão do Império Otomano:

"Durante grande parte de período que se seguiu, as normas e os métodos da Era Mameluca prevaleceram no governo bem como na administração, assim como a grande parte das famílias mamelucas mantinham a sua riqueza e status, fornecendo muitos dos funcionárioschave da nova ordem. Além disso, a reafirmação do controle Otomano central sobre as principais cidades das tribos semi-autônomas e confederações tribais da zona rural. No entanto, as consequências diretas e indiretas das reformas teve o efeito de criar novos interesses e grupos, alguns com compromisso claro com as próprias reformas, outros então buscavam encontrar um papel onde as medidas referentes á reforma resultaram a corroer um estado até então seguro." (TRIPP, 2006 p.14)

No século XIX, o poder otomano estava em declínio. As forças russas haviam se expandido por seu território e logo seriam iniciadas reformas no modelo europeu, como o estabelecimento de escolas seculares, criação de assembleias, com sistema judicial providenciado através de leis civis. Esses governos locais iriam iniciar a construção de um Estado estruturado.

Por volta de 1908, uma segunda onda de modernização invade Bagdá através da influência de Istambul e traz à cena reformas legais e uma política de "turcanificação" que não foi popular com os iraquianos mais intelectuais. Na Primeira Guerra Mundial, o Iraque seria um campo de batalha, e a Grã-Bretanha veio a ter o controle de Bagdá, trazendo assim ao território maior imposição de leis ocidentais.

Havia uma insatisfação intensa, levando assim à anarquia e confrontos violentos entre as tribos e o governo Britânico e à lei islâmica não permite que governos não muçulmanos governem muçulmanos, sendo isso visto então como um chamando a jihad. Essa revolta resulta na morte de 6.000 iraquianos e 500 soldados britânicos e indianos, mas a ordem é restabelecida.

O governo Britânico estabelece um modelo similar ao da Grã-Bretanha, ou seja, uma monarquia constitucional, com um parlamento, assim como um rei. A escolha britânica seria o Príncipe Faisal ibn Hussein, um membro influente de uma família árabe da região e aliado dos britânicos nas guerras arábicas. Porém, ele não era um iraquiano. Não havia ainda a separação do território e havia a questão da fronteira e dos grupos étnicos. 
"As fronteiras territoriais do novo Estado não estavam definidas com precisão, particularmente no que diz respeito à área de fronteira com a Turquia, com maioria curda. Os britânicos tomaram medidas especiais para incorporar os cidadãos curdos. A língua curda foi introduzida como a língua escrita oficial das áreas curdas na província de Mosul, no lugar do turco que tinha sido utilizado em escritórios do governo. Além disso, no dia 20 Agosto de 1920, com o Tratado de Servidores, uma nação curda separada foi planejada, onde os curdos que viviam na área de Mosul poderiam optar por se juntar.” (TRIPP, 2006 p.18)

Em 1925, ocorreram às primeiras eleições no Parlamento, no qual foi estabelecida uma legislação em que as tribos iriam conseguir maior domínio com o intuito da criação de um novo estado. Estas leis iriam também dar concessão do petróleo para uma companhia turca, criando certos privilégios para parte da sociedade, persistindo conflitos referentes a isso até hoje.

Por anos houve uma contínua luta pela independência e, em 1932, o território foi admitido pela Liga das Nações como um Estado, mas ainda sob a influência da Monarquia, mas deveria garantir os direitos das minorias, respeitar as fronteiras e garantir também os direitos as religiões.

Com a Segunda Guerra Mundial o Iraque iria sofrer diversas dificuldades financeiras e haveria pressão sobre a Monarquia. Na década de 40, seriam licenciados sindicatos e o Iraque iria entrar sob o controle dos Comunistas. Com isso, haveria revoluções e o clima político iria se tornar agressivo. Uns grupos de soldados armados tiraram o governo da Monarquia e, em 1958, ocorre um golpe militar no Iraque, que trouxe perigo e turbulência para o país. O líder da junta militar, General Qasim (que encabeçou a revolta), ganhou apoio popular sem precedentes na história moderna do país, em parte devido a razão de sua política desassociar o Iraque da Grã-Bretanha. Porém, com este Golpe estabelecido, uma variedade de grupos políticos buscou espaço no novo regime e com isso, o país chegou a uma situação de desordem. Dentro destes grupos estava o Partido Comunista, o mais organizado e que, por sua vez, toma a voz do governo. Com isso, Qasim usa os comunistas para eliminar seus companheiros de governo que eram leais aos movimentos nacionalistas árabes.

Esse nacionalismo renascerá no Partido Baa'th, em suas duas figuras centrais: Ahmad Hassan al-Bakr e Saddam Hussein, os quais tiveram muita dificuldade em se manterem como líderes do partido e, somente através de muita violência - uma série de 
julgamentos, torturas e prisões foram o marco em seu regime - conseguiram se manter no poder (MARR 2004, p.139).

Por volta dos anos setenta, o partido se mantém através de um totalitarismo, sendo que Saddam agia com extrema violência com a população e sua agenda foi marcada por uma polícia secreta, uma reorganização militar do Baath, para controle total da sociedade, focando principalmente os grupos religiosos.

O Baa'th se estabelece na liderança do sistema econômico, sob a "rubrica socialista" ${ }^{, 53}$, porém estabelece um programa industrial incluindo o desenvolvimento de armas, o sistema de saúde, educação e benefícios sociais. Através da criação destas medidas, o regime conseguia certa aceitação para manter-se no controle do país e, graças a esse desenvolvimento, o Iraque passava a ser grande influência no Oriente Médio.

Houve várias falhas do governo Baathista, tornando-o enfraquecido, levando a um número baixo de membros - não mais que 5.000, em 1968 - e o fraco suporte militar o levou a ter que enfrentar diversas pressões internas dos curdos, dos xiitas e os desafios de fora, como do Irã. Para manter o poder, o partido percebeu que deveria recorrer aos militares. Desta forma, também se iniciou um processo de julgamentos para eliminação dos perigos reais e potenciais.

Neste chamado "reino de terror", Marr (2004, p.141) nos coloca que os julgamentos começaram logo que o partido tomou o poder, sendo que também se envolveu em várias acusações como espionagem para os Estados Unidos, Israel e do Xá Pahlevi, bem como as conspirações para a derrubada do governo. $\mathrm{O}$ autor ainda afirma que a validade das acusações poderia ser largamente questionada, não demonstrando ter fundamentação. Todavia, com essas acusações, conseguiram atingir seu propósito, que era de instalar maior temor e pânico em sua população.

Com os julgamentos, o Baa'th demonstrou que nenhum atentado os tiraria do poder e o primeiro grupo a ser eliminado foi o partido que compunha anteriormente o poder. Na Hawza estavam os sábios xiitas que sempre defenderam o posicionamento da Escola Islâmica para a nação iraquiana e estes virariam um alvo para o Partido.

No período do golpe militar, Assadr era apenas um jovem, porém ele consegue exercer influência no grupo Jama 'at Al-Ulammah - grupo dentro da Hawza - através de

\footnotetext{
${ }^{53} \mathrm{O}$ Partido se declarava socialista, porém pouco se assemelhava com outros Partidos socialistas no Oriente Médio, de fato criava um sistema próprio dentro do Iraque, onde acaba por instalar uma milícia que iria perseguir seus cidadãos que se mostravam em desacordo com aos seus ideais. (MARR, 2004, p. 139)
} 
seu irmão mais velho Sayeed Ismail. O Jama'at tinha por objetivo enfrentar os desafios do comunismo e o grupo consegue agir naquele momento de forma bastante realista, apaziguando o popular Qazim e apoiando em seus manifestos enquanto atacava seus ideais comunistas.

Com isso, Qazim oferece ao grupo acesso à rádio controlada pelo governo e as mensagens do grupo eram escritas por Assadr. Esse período não dura muito, pois AlHakim emite um decreto no qual identifica o comunismo com o ateísmo e proíbe os muçulmanos de aderirem ao Partido, o que causa embaraço ao General Qazim.

O Baath, mesmo se afirmando como secular, era dominado pelos grupos sunitas e estes se apresentavam mais propensos à modernização. Já os xiitas, menos receptivos às reformas, iriam buscar modificações procurando levar a população a uma reação a essas mudanças sociais, que não se apresentavam aprovadas pela liderança xiita.

\begin{abstract}
"Enquanto o secularismo afetava tanto sunitas e xiitas, seu impacto sobre os xiitas foi mais perturbador. Primeiramente os conceitos básicos do Islã xiita repudiam a própria idéia de separar a religião do Estado ou da política. De um modo geral, os xiitas também são mais rigorosos do que os sunitas e menos receptivo às idéias modernistas, como aquelas que estão sendo divulgados pelos Ba'th. Praticamente falando, parece que o peso da secularização ou a quebra do poder da religião fora dirigido principalmente contra os xiitas. Assim, no verão de 1976, o Ba'th desencadeou uma campanha de repressão contra os homens xiitas e as instituições que incluíram: o encerramento de instituições islâmicas que incluíram uma faculdade teológica em Najaf; a imposição de uma censura rigorosa em publicações religiosas; a autorização da venda de álcool nos locais sagrados xiitas supostamente, pela primeira vez na história do Iraque; e perseguição de Ulemas xiitas geral. Estas medidas provocaram manifestações xiitas ferozes que foram organizadas por homens xiitas da religião e que o regime reprimiu pela força. Esta crise poderia ter sido desencadeada pela disputa Shatt al-Arab com o Irã, que tinha entrado em erupção em Abril de 1969. Parece, no entanto, que a sua causa fundamental foi a determinação do regime de quebrar o poder dos homens da religião e da influência que a religião [...].(BENGIO, 1985, p.2)
\end{abstract}

O Baa'th desejava disseminar sua ideologia para os xiitas, porém não conseguiria isso com o sucesso que desejava, sendo dominado pelos sunitas. Assim, os xiitas e curdos estavam fora do poder político e iriam sofrer diversas consequências.

As perseguições, como descrevemos na primeira parte do capítulo, iriam se intensificar cada vez mais, mas é com a ascensão de Saddam Hussein que ocorreria seu ápice. Depois de muitos anos de esforço e trabalho Saddam consegue se estabelecer no Baa'th como um líder e, para consolidar seu poder, ele invade seu vizinho persa, o Irã, 
pois tentava se precaver da influência xiita. Como base para essa invasão, usa a disputa histórica pelas terras e água, mas de fato a Revolução Islâmica no Irã era seu grande temor.

A Revolução islâmica no Irã foi crucial ao nosso autor. Havia um temor referente aos xiitas e Saddam decide tomar atitudes mais drásticas depois de janeiro de 1979, pois quando Khomeini ascende ao poder, este serve como uma fonte inspiradora. Estava posta a mensagem de que juntos os xiitas poderiam derrubar o Baath e estabelecer uma República Islâmica como no Irã.

“[...] revelado o 'fenômeno religioso-político " recebeu um grande impulso com a revolução iraniana de 1979; por isso tivemos al-Da'wa. Algumas razões foram apresentadas para o fato de que esta tendência se enraizou entre iraquianos apesar da natureza e os esforços dos Ba'ath: (a) Os religiosos - movimentos políticos explorados 'para encobrir suas atividades políticas destrutivas' ritos religiosos, portanto, era difícil para o Estado para rastreá-las;” (BENGIO, 1985, p. 9).

Com o avanço e a organização dos xiitas, assim que Saddam toma o poder, elimina seus inimigos mais poderosos dentro do grupo. Sendo assim, leva muitos à morte. Os xiitas levariam anos então para conseguir se reorganizar novamente e tomar parte no poder político do Iraque.

\subsection{O Movimento Sadrista}

O trabalho de Baqir Assadr tem grande repercussão, seu legado se perpetua até hoje dentro do Iraque. Hoje seu legado segue por Muqtada Assadr dado como um movimento de reavivamento do xiismo dentro do Iraque.

Assadr buscou restaurar o Islã na vida dos muçulmanos, procurando estabelecer um governo islâmico, que pudesse transformar a sociedade iraquiana, afastando o socialismo, o capitalismo e o comunismo ali presente e, antes de seu falecimento, Baqir Assdr forma Sadiq Assadr que também se opunha a um governo secular, ao qual Muqtada Assadr procura dar continuidade até hoje.

Sadiq Assadr continua seus estudos ganhando mais tarde o título de grande Aiatolá que o qualificou para ser líder do movimento xiita em 1992 e acaba ficando conhecido 
como Assadr II $^{54}$. Sadiq Assadr fica em prisão domiciliar por dez anos devido a sua retórica antibaathista. Saddam temia de fato o poder dos Assadr em conseguir cooptar toda a população e também desejava conseguir controlar a comunidade shiita. Obviamente, Sadiq Assadr também foi escolhido por sua linhagem sanguínea, que o ligava a Baqir Assadr, também morto por Hussein.

Entretanto, Sadiq Assadr diferente de Baqir não se importava com política, não dava apoio a nenhum partido e não procurava este tipo de poder, posicionava-se como um nacionalista e defendia que os xiias e sunitas deveriam viver em harmonia e deveriam ter os mesmos direitos dentro do país, já que os xiitas foram sempre discriminados pelo partido Baa'th.

Como seu primo, Sadiq foi preso diversas vezes e mais tarde começaria a ser um severo crítico da forma pacífica da população xiita, acreditando que a militância seria mais adequada. Segundo Hollinger (2009, p.33), de certa forma ele conseguia fazer o regime acreditar que estava sob controle e aos poucos ele iria conseguir construir um movimento com a massa iraquiana, fazendo o xiismo ser mais relevante, atendendo as necessidades espirituais, psicológicas e econômicas da população. Ou seja, Sadiq parecia ser capaz de enganar o regime.

Outro ponto importante do seu movimento, o Sadrismo sempre atingiu as massas no Iraque. Seus líderes falavam aos pobres, atingiam as preocupações destes, não a elite iraquiana. Os discursos de Sadiq Assadr abordavam temas que eram preocupações da população como falta de eletricidade e água, dentre outros serviços e assim eles conseguiam movimentar a população xiita contra o Regime de Saddam. Assim, sua luta o levou a ser assassinado em Fevereiro de $1999^{55}$.

Seus dois filhos mais velhos que poderiam ser seus sucessores também foram assassinados, deixando Muqtada Assadr como sucessor do movimento, sendo que a princípio não se posiciona como uma ameaça a Saddam porque não possuía as mesmas credenciais de seu pai.

Quando da invasão ao Iraque, sua retórica sempre foi antiamericana, fazendo com que os EUA olhassem o Muqtada Assadr com um perigo. Porém, hoje a preocupação na região deixa de ser com os xiitas e o Movimento Sadrista ganha força em sentido social

\footnotetext{
${ }^{54}$ HOLLINGER, M. Muatada Al-Sadr. How to Demilitarize Al-Sadr. Thesis, naval Postgraduate School, 2009, p.31.

${ }^{55}$ Idem, p. 34-35.
} 
no Iraque. Muqtada Assadr hoje procura espaço somente religioso, alegando que não deseja cargos políticos, mas pretende dar continuidade ao legado religioso e social aos xiitas. 


\section{CAPÍTULO II}

"Ainda está por nascer o primeiro ser humano desprovido daquela segunda pele a que chamamos de egoísmo,

bem mais dura que a outra, que por qualquer coisa sangra".

José Saramago

\section{A ECONOMIA ISLÂMICA SEGUNDO ASSADR ${ }^{56}$}

\subsection{Introdução}

Para os muçulmanos, o Islã apresenta um sistema completo para a vida e seu desejo é construir um sistema que possa abarcar toda a vida e cultura, trazendo valores éticos e princípios, podendo assim liberar a vida dos muçulmanos dos sistemas laicos. Com isso, autores com base na área de História e Religião, dentre outras áreas, tentavam discutir as questões econômicas. No entanto, Iqtsaduna de Baqir Assadr consegue abordar quase todos os temas naquele período, incluindo os desafios contemporâneos.

Infelizmente, seu trabalho não tem sido muito explorado, nem mesmo no Irã, parecendo que sua obra Iqtsaduna não desfruta de tanta popularidade como seus outros trabalhos. Mesmo sem uma formação na área econômica e sociológica, sua pesquisa não deixa a desejar. Outro fator importante, diferente de outros estudiosos deste revivalismo islâmico da década de sessenta, Assadr não havia tido contato prévio com o ocidente: suas teses se baseiam em puro estudo dos ensinos islâmicos. ${ }^{57}$

Em seu livro, o autor faz um estudo analítico do marxismo, do capitalismo e da economia islâmica, abordando os princípios dos sistemas, base moral e sua aplicação. Apesar de sua formação religiosa, o autor não apresenta problemas em compreender e analisar o marxismo e o capitalismo. Obviamente, sua análise tenta apresentar uma superioridade do sistema islâmico. De fato, o que mais surpreende em seu trabalho é que

\footnotetext{
${ }^{56}$ Assadr possui uma obra extensa, contando com livros sobre os fundamentos da Lei Islâmica sobre jurisprudência islâmica, um livro sobre a Filosofia Islâmica "Falsafatunah" que foi a preparação para a escrita do livro "Iqtsaduna". Aqui estão sendo citados e analisados seus principais trabalhos e sua pesquisa para o governo do Kuait sobre o sistema bancário, que se encontra traduzido como anexo a esta pesquisa.

${ }^{57}$ EL-ASHEKER, Ahmed, WILSON, Rodney. Islamic Economics: A Short History, 2006, p.393.
} 
não foca apenas um ponto da economia islâmica, mas Assadr faz um trabalho comparativo e ainda completo, diferenciando-o dos outros autores do mesmo período ${ }^{58}$.

\subsection{A Doutrina Econômica e o Islã}

O Islã oferece um caminho para a vida econômica, trazendo informações suficientes para elaboração de uma doutrina que muitas vezes é considerada restrita, abordando somente a distribuição de riqueza, mas que, na visão de Assadr, oferece métodos e objetivos particulares. Para o autor, consiste de regras para a vida econômica ligada à ideologia da justiça social, sendo que essa ideologia da justiça é a linha divisória entre a ideologia e a ciência ${ }^{59}$, demarcação essencial na sua visão para que sejam realizadas as obras islâmicas.

Segundo Assadr, a visão doutrinária do Islã não afastou a possibilidade de seu modelo econômico assumir um quadro científico, mas seu papel é assumir os problemas da vida econômica ligada às concepções de ideologia e seu ideal de justiça ${ }^{60}$.

O autor oferece um destaque na questão da ligação entre a doutrina e o código civil, já que é através da lei que seu modelo econômico poderá se manifestar na sociedade. Os decretos islâmicos referentes às relações monetárias e pecuniárias dos indivíduos serão a ferramenta de trabalho do Estado Islâmico. O sistema financeiro também é limitado ao código civil, fazendo uso deste como uma superestrutura da doutrina econômica islâmica.

O autor faz uso do que ele chama de "exemplo ilustrativo" da economia capitalista

\footnotetext{
${ }^{58}$ Os autores buscavam discutir apenas um tópico, a propriedade privada, a ética, distribuição, desenvolvimento, papel do estado, mas Assadr faz uma pesquisa mais completa discutindo todos os temas.

59 “A justiça é apenas uma avaliação moral ou uma apreciação moral. Então, quando alguém quer conhecer o escopo da justiça a respeito do sistema da propriedade privada ou emitir um julgamento sobre a instituição dos juros sobre a qual o sistema bancário se baseia, quanto se é justo ou injusto, não recorre àqueles meios e padrões de medida científicos que se utilizam quando se quer medir o grau de calor atmosférico ou com que se examina o ponto de ebulição de um determinado liquido, pois o calor e a vaporização são fenômenos que podem ser submetidos à percepção científica, mas quanto à apreciação da justiça recorre-se a valores éticos e a ideias mais elevadas que estão fora dos limites da medição material". (ASSADR, 2012, p.329).

${ }^{60}$ Aqui o autor faz menção à incorporação do harām (o ilícito) e halāl (o lícito) na economia doutrinária islâmica, que se estende para o autor no comportamento do governante, do comprador, do vendedor, ou seja, a doutrina comportamental poderá se estender a todas as atividades humanas e a todos os gêneros de comportamento. Para Siddiqi (1972, p.12-13) as leis islâmicas que regem a economia refletem o espirito islâmico na sociedade, onde o autor vê a materialização através da cultura a ser implantada, não especificamente a lei, mas todo um arcabouço de ações da sociedade.
} 
como convencional para partir para a construção de sua teoria de distribuição da renda antes da produção e pós-produção. Seu trabalho de comparação serve como base para depois expor suas ideias à base do Corão.

\subsection{Descoberta Operacional da Doutrina ${ }^{61}$}

A doutrina econômica islâmica nasce através do desenvolvimento da lei islâmica, ou šari 'ah. Para o autor, um pesquisador da economia islâmica não deve visualizá-la como uma coletânea de regras islâmicas ${ }^{62}$, deve buscar a doutrina e suas teorias e regras fundamentais, a forma e a fundação da estrutura superior da lei civil islâmica. Assim conseguirá compreender o modelo econômico islâmico. De fato, como metodologia de desenvolvimento de pesquisa no Islã, será a lei islâmica a base. Kahf (1978, p.6) argumenta que "um sistema para a economia islâmica deve ser formulado da base da doutrina islâmica que rege a vida diária dos muçulmanos" e assim estes princípios purificarão o sistema.

Para o autor, o trabalho de pesquisa de um economista islâmico difere do trabalho de pesquisa dos expoentes das outras doutrinas econômicas, pois o pensador islâmico se vê diante de um sistema de economia inteiramente formado e acabado ${ }^{63}$ e seu trabalho será a determinação de seu quadro estrutural, buscando "a revelação de suas regras de raciocínio (que a governam), a superação, até onde sejam possíveis, da densidade dos acúmulos do tempo e das longas distâncias entre os intervalos históricos" (ASSADR, 2012, p.336).

O papel do pensador será de fato libertar a estrutura das culturas não-islâmicas que dominam os sistemas, ou seja, o que é levantado como economia islâmica é o processo de islamização. ${ }^{64} \mathrm{E}$ em seu livro, Assadr apresenta os regulamentos relativos à

\footnotetext{
${ }^{61}$ Para o autor, o trabalho de pesquisa que se deverá efetuar na economia islâmica é um processo de descoberta de um sistema que já está estabelecida no Corão.

62 "Mas enquanto enfatizamos a necessidade de fazer a separação entre a natureza teórica da doutrina econômica e do código de direito civil não fazemos com isso uma ruptura na relação que permanece entre ambas, ao contrário, ao mesmo tempo enfatizamos o forte elo e relacionamento que as une, no sentido de serem partes componentes de uma compacta, orgânica e complexa realidade". (ASSADR, 2012, p.332)

63 “" [...] o processo de descoberta, o curso do procedimento de trabalho a seguir é o inverso, e eis que quando estamos diante da descoberta não temos posse de um quadro explícito dela ou algum aspecto ou forma definida da mesma antes que seja formada”. (ASSADR, 2012, p. 336-337)

${ }^{64}$ Esse processo ocorre do plano superior para a base da estrutura.
} 
muamalat (as relações pecuniárias e pessoais), leis para o gerenciamento das relações financeiras do Estado e da nação, lança a estrutura de rendimentos do Estado, a política para esses rendimentos e como essas regras formaram a superestrutura da doutrina.

Aqui percebemos suas ideias para uma reforma islâmica, um processo de islamização que envolvesse todos os campos da sociedade. O autor apresenta as condições iniciais, mostrando que há uma estrutura ideal para isso, ou seja, que os muçulmano, possuem valores éticos para que se reelabore uma sociedade mais justa em sua visão e seu trabalho na Hawza parece mostrar que isso partirá da educação. ${ }^{65}$

Seu texto apresentou e debateu o que seriam os pontos de equalização no processo de islamização: equalização da distribuição de renda, sendo importante o controle da propriedade privada; eliminação dos elementos exploratórios, sendo que o trabalho deverá se tornar uma forma de ganho; elaboração de programas sociais; renovação de uma ética para os negócios, com a eliminação da usura; e o estabelecimento de impostos obrigatórios com a ideia de uma sociedade igualitária.

Será a partir das concepções de vida do Islã ${ }^{66}$ que se criarão as leis que darão forma à economia islâmica de Assadr. A doutrina econômica islâmica é descrita pelo autor de forma definitiva, não admitindo nenhuma mudança ou modificação. Mas há uma lacuna para o autor, e o governante deve preencher esta lacuna de acordo com suas habilidades de resolução das condições e circunstâncias.

${ }^{65} \mathrm{O}$ partido parecia restaurar o Islã na vida nos muçulmanos, através da aplicação da sharia e com isso foram estabelecidos dois estágios. O primeiro era transformar a vida dos muçulmanos através da mudança da comunidade, trazendo o Islã à vida diária. A segunda fase seria a sua aplicação na política, e assim eles precisariam travar uma luta armada contra os inimigos. Esse ideal de fato é atingido por Khomeini com a Revolução Iraniana em 1979 que sempre teve o apoio dos xiitas iraquianos. Porém, no Iraque, Assadr consegue apenas a aplicação da primeira fase deste processo que durou 22 anos, agindo nos bastidores. Mas esse início foi significativo, pois o movimento Sadristra perdura no Iraque até hoje. Com sua mudança de enfoque dirigindo a sua carreira para a Hawza, o autor decide trabalhar na mudança do currículo do curso, pois ele verifica que os alunos não eram tão regulares às aulas e estavam negligentes, portanto propõe um novo livro, já que os utilizados não eram escritos para estudantes, pois não levavam em conta a capacidade do aluno de entender o islamismo.

66 "A primeira dessas concepções é a concepção islâmica da propriedade de acordo com a qual Deus designou um grupo de pessoas como seus vice gerentes sobre os bens e as riquezas naturais, e criou de uma legislatura o decreto da propriedade privada e o modus operandi, dentro do qual um indivíduo pode perceber os mandatos da vice gerência como um aumento dos bens e da propriedade confiada a ela, a proteção e a distribuição dos mesmos, e o bem estar do ser humano. Assim a propriedade é uma operação que um indivíduo põe em prática em conta da sociedade e dele mesmo dentro da sociedade. A outra concepção, que tomamos por empréstimo e em adiantamento da futura discussão é o ponto de vista do Islam com respeito é negociação como um dos fenômenos da vida econômica". (ASSADR, 2012, p.344) 
Assadr dá destaque ao que chama de criação da doutrina econômica que, a seu ver, seria uma invenção, uma formulação completa da sociedade, um pensamento que realiza um trabalho, formula de maneira direta as teorias gerais de uma doutrina. Mas aqui nem sempre seriam impostas as questões éticas que poderiam estruturar uma sociedade mais justa. Seriam em si um procedimento que estaria sujeito a falhas. Por isso o Islã não se pautaria por este caminho.

No Islã, é estabelecida uma dependência entre a doutrina econômica e o código de direito civil, já que o código é descrito como o plano superior diante da doutrina e recebe dela a direção para a criação das leis.

O processo de descoberta da doutrina islâmica é feito através das regras legais e concepções, sendo que o método utilizado pelo Islã é a extração das leis do Corão ${ }^{67}$ e da $S_{\text {Suna }}{ }^{68}$. Ou seja, a lei islâmica será extraída pelo exercício do ijtihā ${ }^{69}$, sendo que o

${ }^{67}$ O Corão foi revelado ao Profeta em árabe e é considerado a Palavra de Deus, sendo o principal dos livros Sagrados. No decorrer dos últimos vinte e três anos de vida do Profeta as revelações foram memorizadas e estas foram escritas por seus fiéis logo após seu falecimento. (ALMUZAFFAR, 2009, p.69-70). As suras com teor teológico foram reveladas durante o período em que estava em Meca e as que estavam em Medina possuem conteúdo político, social e legal para os muçulmanos. O monoteísmo (altawhìd) permanece como ideia central desta obra e outro aspecto importante é a aceitação do Profeta como último mensageiro do Criador. A partir desta divisão, ficaria mais compreensivo o Corão, sendo assim foram separados as suratas (alīat) ao que seriam preceitos legais. Destas, 70 são referentes à família e à herança, outras 70 sobre obrigações e contratos, 30 sobre a área criminal e 30 sobre procedimentos. Importante ressaltar aqui - e será visto durante o texto - que o principio da analogia tem estendido a aplicação do Corão a outras partes da legislação. Por si só o Corão não é um texto de lei, apenas algumas declarações que constituem regras que podem ser aplicadas diretamente. Estas são as que consistem em preceitos próprios para um comportamento ético.

${ }^{68}$ A segunda fonte a ser considerada é a Sunna, que consiste da compilação dos ensinamentos do Profeta Maomé. Essas tradições proféticas denotam a maneira, jeito, regra ou modo de conduzir a vida, sendo aqui importante essa definição, pois a sunna é resultado das histórias tradicionais transmitidas pelo Profeta. Essas histórias compõem a coleção de hadith que contém normas, atos, preceitos e consentimentos do Profeta que foram transmitidos e relatados por seus companheiros que tiveram contato direto e dele ouviram tais relatos, através de uma cadeia ininterrupta de transmissão de informações. Esses ditos, ou coletânea de hadith, ainda passaram por um processo de avaliação pelos primeiros sábios muçulmanos que estudaram a corrente de transmissão de cada relato, analisando as condições em que cada hadith foi relatado, bem como a conduta, a honra e a credibilidade de cada um dos relatores. Portanto, temos duas formas de classificar estas coletâneas: pelo grau de autoridade e a pessoa em quem a autoridade deste hadith foi recebida.

${ }^{69} \mathrm{O}$ ijtihăd compreende as resoluções jurídicas, ou seja, o resultado do empenho intelectual dos juristas que fazem uso da analogia para a elaboração destas resoluções. Como metodologia, os estudiosos da Lei Islâmica fazem uso do Corão e da Sunna para dar resolução às questões judiciais atuais. Esse grupo de estudiosos é formado por especialistas como teólogos, juristas, médicos, economistas. Essas resoluções jurídicas buscam uma reforma da sociedade em termos legais. $\mathrm{O}$ ijtihād é o principal instrumento de interpretação da mensagem divina e a possibilidade de contemplar as aspirações de justiça, salvação e verdade tanto desejada pela comunidade muçulmana. A razão é fundamental neste processo de interpretação, se tornando assim um 
próprio autor, em seu texto, salienta a possibilidade de erro no processo de extração da doutrina econômica.

O risco surge no processo de extração do ijtihād devido à subjetividade, já que o elemento pessoal participa na contribuição, e esse risco será agravado quando das grandes distâncias históricas e factuais que separam a pessoa do Mujtahid dos textos os quais ele exerce seu $i j t i h \bar{a} d$. O autor traz diversos exemplos do processo de extração, procurando explicar sua metodologia, trazendo ainda sua ideia sobre o processo abstrativo de desenvolvimento da doutrina, a separação da prática de suas efetivas condições e circunstâncias e de sua existência histórica desde a época da legislação islâmica. ${ }^{70}$

Assadr não nega que a adoção de um ponto de vista definido de antemão para com os textos gera uma tendência que a não objetividade pode extraviar o Mujtahid da compreensão dos textos legais, levando a um erro da dedução da regra geral destes textos.

Com isso, será visto que os ijtihād diferem e variam segundo a diferença dos Mujtahids em sua compreensão dos significados dos textos, em sua maneira de tratar as contradições que podem surgir entre alguns dos textos ${ }^{71}$ e nas regras e padrões gerais do pensamento jurídico que venham a adotar. ${ }^{72}$ Isso não quer dizer que o ijtihād perde sua

instrumento de harmonia entre o passado e presente. O ijtihād significa em si um esforço intelectual extremo com o intuito da formação das leis que irão compor o direito islâmico. Para o exercício do ijtihād, deve-se possuir grande conhecimento da Sunna.

70 “[...] ocorre sempre que estudamos uma prática contemporânea à época da legislação islâmica e tentamos descobrir a sanção do Islã para ela com base no silêncio da šari'ah a respeito da mesma. Sob essa circunstância, a pessoa que exerce o ijtihād tende a cair no erro da abstração quando separa a prática contemporânea à época da legislação islâmica de suas circunstâncias, isolando os fatores que podem ter participação em sua permissibilidade e a generaliza com o parecer que essa prática é correta e válida no Islam sob todas as circunstâncias, embora o intuito da interferência com base no taqrir seja objetivo, é necessário que adicionemos à nossa avaliação todas as circunstâncias que possam provavelmente afetar a posição do Islam a respeito daquela prática, pois quando algumas dessas circunstâncias e condições mudam, a interferência com base no at'taqrir se torna sem sentido". (ASSADR, 2012, p.359)

71 "Sendo assim, para a fidelidade de cada um desses textos, com exceção dos textos alcorânicos e uma pequena parte dos textos da Sunnah, devem ser estabelecidos por tawatúr (corrente contínua de transmissão). Temos que confiar na narração de um desses transmissores ou muhaddiçin (conhecedores das tradições). E em seguida, cuidadosamente podemos investigar o histórico das transmissões até que ponto vai sua confiabilidade e fidelidade para com sua transmissão, conquanto, estejamos cientes disso quanto aos transmissores, e não de uma maneira direta e, desde que há a possibilidade de que o transmissor fiel, sendo falível, possa ter interpretado equivocadamente o texto e o transmitido a nós de modo diverso, especialmente em circunstâncias em que o texto possa chegar a nós somente depois de circular pelas mãos de vários transmissores, cada transmissor passando até que nos chegue após uma longa jornada, não podemos estar absolutamente certos de sua fidelidade". (ASSADR, 2012, p.364)

72 "Disso resulta a ampliação de nosso inventário a respeito da economia islâmica e a presença de múltipla variação de suas formas, todas elas da šari'ah e islâmicas, é em semelhante caso que 
validade ou não está autorizado a ser aplicado. Com isso, Assadr argumenta que o Islã permitiu sua prática e fixou para o Mujtahid o limite no qual ele pode confiar sua opinião dentro das regras formalmente expostas com a ciência dos princípios da lei, e não há nenhuma culpa de sua parte se o Mujtahid baseia sua opinião dentro dos limites permitidos, quer esteja certo ou errado. ${ }^{73}$

Para o autor, deve ser possível distinguir a realidade legislativa islâmica que o Profeta tinha enunciado e a forma tal como descrita por um mujtahid através de sua pesquisa de textos. Ou seja, a legislação islâmica no campo econômico não se produziu de maneira extemporânea e nem nasceu de pontos de vista isolados um do outro. Ao contrário, a realidade islâmica nesse campo se construiu sobre uma base unificada e um equilíbrio comum de concepções. ${ }^{74}$

Houve para Assadr, um modelo econômico islâmico na época do Profeta, sendo que este modelo existiu em um nível prático aplicado à realidade existente das relações econômicas. Em razão disto, se torna possível que esse processo de descoberta seja estudado e que se busque uma doutrina, de aplicação, ao mesmo tempo que é possível ao nível teórico, visto que essa prática aplicada define as características e os traços da economia da mesma maneira que os textos teóricos as definem no âmbito da šari ${ }^{6} a h^{75}$.

podemos escolher em todo âmbito o mais efetivo e o mais forte dos ingredientes que encontremos naquela forma para o tratamento dos problemas da vida ( socioeconômica), e a realização da mais elevada meta do Islã. Esse é o âmbito da escolha pessoal, no qual o investigador é o mestre de sua liberdade e opinião, porém, ele é livre apenas em sua posição de pesquisador. Entretanto, essa subjetividade não mais será uma opção, nem uma inovação, pois isso faz com que se dê a ele liberdade limitada à órbita de diferentes ijtihād e não uma liberdade completa.[...] a descoberta da teoria islâmica e do princípios doutrinários fundamentais sobre a ciência da economia(unidos num todo) completo, harmônico e homogêneo, com sua estrutura superior e suas particularidades legislativas e ramificações jurídicas só é possível baseando-se no âmbito subjetivo de escolha". (ASSADR, 2012, p.362-363)

${ }^{73}$ É lógico e esperado que se encontre em todo mujtahid uma quantidade de erros e contradições com a realidade do pensamento e a legislação islâmica. Ou seja, no próprio trabalho do autor será encontrada contradições de acordo com a legislação islâmica.

${ }^{74}$ Devem-se considerar os preceitos como sendo a estrutura superior que deve ser atravessada para o que seja mais profundo e mais abrangente e daí se descer às bases nas quais será erigida e que expressam suas generalidades e seus pormenores e ramificações explicados, sem contradições.

75 “Todavia, os textos teóricos legislativos são mais capacitados a formar uma descrição da doutrina do que a realidade existente aplicada, uma vez que a aplicação dos textos legislativos a uma condição definida provavelmente não é capaz de refletir um grande conteúdo daquele texto e nem é capaz de visualizar seu significado social integral". (ASSADR, 2012, p.369) 


\subsection{Estrutura Geral}

Para o autor, haverá três elementos principais na estrutura da economia islâmica: forma dual da propriedade privada, a liberdade econômica em uma esfera limitada e a justiça social.

Um dos grandes debates da economia é a questão da propriedade privada. A estrutura econômica permitida por um Estado Islâmico consiste na propriedade privada e a propriedade pública, mas para o autor isso não significa que o modelo islâmico traga em si uma combinação entre o capitalismo e o socialismo, sendo que essa ideia é fortemente rejeitada em seu texto. ${ }^{76}$ A questão do direito à propriedade pública e privada no Islã está baseada em crenças fundamentais aos muçulmanos, sendo, para seus teóricos, algo lógico.

Esse reconhecimento da propriedade privada é algo abordado por diversos autores. Mannan (1995, p.101) declara:

"O Islã reconheceu a terra como um fator de produção não exatamente o sentido em que é usado em tempos modernos. Concepção clássica, que a considerava como um importante fator de produção, incluindo todos os recursos naturais utilizados no processo de produção, por exemplo, a superfície da terra, a fertilidade do solo, as propriedades dos recursos hídricos e minerais e do ar, etc.

Para melhor compreensão, podemos comparar a perspectiva do individualismo, que se torna o grande alicerce do liberalismo, dando ao indivíduo o papel central na filosofia política e econômica liberal, dando a este assim o direito à vida e à propriedade. No Islã, sendo de Deus todas as propriedades, este fornece a seus súditos o direito ao seu

\footnotetext{
76 "Eis porque é errôneo chamar a sociedade islâmica de capitalista a despeito do fato de que ela permita a propriedade privada em relação a um número de capitais e meios de produção, já que não reconhece a propriedade privada como um princípio absoluto. De modo similar, é um equivoco dar a sociedade islâmica o nome de "sociedade socialista" embora ela adote o princípio de propriedade pública como também a estatal com respeito a alguns tipos de riquezas e capitais, desde que em sua opinião a propriedade socialista não constitui um princípio absoluto. [...] É também um equívoco considera-la como uma mescla de capitalismo e socialismo, pois a variedade de formas básicas de propriedade na sociedade islâmica não significa que o islã tenha misturado às duas doutrinas e adotado aspectos de ambos". (ASSADR, 2012, p.255)
} 
usufruto, ou seja, a questão da propriedade a um direito divino e tem base na ideologia religiosa.

O segundo elemento da economia islâmica é a liberdade, que o Islã estabelece para o campo da economia. ${ }^{77}$ Porém, essa restrição à liberdade está baseada nos valores espirituais e morais do Islã. O autor trará dois tipos de restrição. Primeiramente, a restrição pessoal que nascerá do desenvolvimento espiritual do ser humano de delimitar sua vida diária pelas leis islâmicas e a prática religiosa. Segundo, será a restrição estabelecida externamente, que define e regula o comportamento social na sociedade islâmica.

A restrição pessoal desenvolvida sob a sombra de um treinamento e educação pessoal dado a um indivíduo em uma sociedade islâmica ${ }^{78}$ é comprovada pelos resultados do desenvolvimento atingido no período inicial do Islã.

O propósito da restrição é baseado no princípio de que não haverá liberdade para um individuo, quando se tratar de atividades que vão contra as regras da šari ' $a h^{79}$ e a implementação deste princípio se materializa de duas formas: primeiramente a šari 'ah baniu certas atividades econômicas e sociais que contradizem com os valores e ideais adotados pelo Islã, como a usura. ${ }^{80}$ Segundo, a šari 'ah dá autoridade ao governante (wal̄ 'amru) para supervisionar e intervir nas atividades públicas com o intuito de promover os interesses sociais. ${ }^{81} \mathrm{Ou}$ seja, essa autoridade goza do direito de obediência e interferência

\footnotetext{
77 "A liberdade no Islã, porém, preserva o lado revolucionário da liberdade e age para libertar o ser humano do domínio dos ídolos - todos eles - que extenuaram a humanidade durante um bom tempo da história. Porém, ela estabelece a operação da grande libertação com base na crença sincera da servidão a Deus, e somente a Deus. A servidão do ser humano a Deus no Islã - ao invés de ser dono do seu nariz no capitalismo- é o instrumento com o qual o ser humano destrói qualquer autoridade e qualquer outra escravidão, porque essa escravidão, no seu conceito sublime, o faz sentir unido com todas as outras forças, com quem convive no mesmo pé de igualdade perante um único Senhor". (ASSADR, A Escola Islâmica, 2010, p.66)

78 "Esta restrição pessoal tem um grande e esplêndido efeito na formulação da natureza da sociedade islâmica e em sua índole. [...] Se esta experiência pudesse continuar por mais tempo do que um momento da história, teria provado a competência do homem para o califado na Terra, a teria preenchido com sentimentos de justiça e misericórdia e extirpado da humanidade os elementos do mal e os impulsos à injustiça e corrupção". (ASSADR, 2012, p.257).

${ }^{79} \mathrm{O}$ Islã cria um sistema tridimensional que fará a ligação entre Alá, o homem e a sociedade. As fontes do direito islâmico são o Corão, a Suna (tradições do Profeta Maomé), ijmā (consenso de opinião) e o ijtihād (resoluções dos sábios e jurisprudência).

${ }^{80}$ A usura é entendida como a cobrança de remuneração abusiva pelo uso do capital, quando da cobrança de um empréstimo. Este ponto será debatido futuramente como um tópico à parte nesta análise.

81 “[...] a Lei Sagrada estabeleceu o princípio do governante (wal̄ 'amru) supervisionando as atividades gerais do povo no país e a intervenção do Estado com vista de salvaguardar e promover
} 
para salvaguardar o interesse da sociedade e manter o equilíbrio dela. Portanto pode intervir dentro dos limites da šari 'ah.

A visão de Siddiqi (1981, p.79-80) é similar a de Assdr. Para o autor, a lei islâmica dá ênfase à obrigação em vez dos direitos, pois estas são de fato para o próprio benefício da população. No Islã, os direitos de fato emergem das obrigações, não existindo direito absoluto dentro da lei islâmica.

Para Assadr, um governante de visão não pode transformar algo ilícito em lícito, no entanto, poderá intervir nas atividades que são permitidas pela lei islâmica. Assim ele poderá permitir e proibir as atividades dentro dos ideais islâmicos. Como forma de justificativa, o autor menciona os casos nos quais o Profeta interveio nas atividades diárias das pessoas que estavam ao seu redor. ${ }^{82}$ Isso apenas demonstra a questão do direito de interferência da autoridade em assuntos públicos. Os papéis de cada membro na sociedade são bem trabalhados dentro da lei islâmica, oferecendo assim, tanto para as relações de comércio quanto para as relações financeiras (bancárias), normas éticas claras e específicas.

O terceiro elemento da economia islâmica é o princípio da justiça social que está incorporado pelo Islã no sistema de distribuição da riqueza dentro da sociedade islâmica. De acordo com o autor, o significado de justiça social no Islã é tão amplo que cada aspecto da sociedade terá incorporado o conceito de justiça ${ }^{83}$ em sua busca. De fato, para a questão de justiça, o autor verá o homem como o ponto principal, já que seu desejo é de construir um ser humano melhor que, para Assadr, é aquele que busca os princípios islâmicos para sua vida.

os interesses públicos, por meio da restrição da liberdade dos indivíduos em suas atividades." (ASSADR, 2012, p.258) A base desta crença está no Corão: "Ó fiéis, obedecei a Deus, ao mensageiro e às autoridades dentre vós" (Corão C.4, v.59) Para o autor, o texto deste versículo prova a obrigação de se obedecer às autoridades.

82 "O próprio profeta costumava implementar esse princípio de interferência quando a necessidade exigia e a situação necessitava de interferência e direção. Um exemplo disto é a tradição autêntica que relata que o profeta teve de decidir entre o povo de Medina num caso sobre o fornecimento de água para as palmeiras, dizendo que o excedente de algo não deve ser negado a outrem. Ele também deu, num caso que surgiu entre o povo do deserto, o veredicto de que nem o excedente de água nem a pastagem deveriam ser negados. De modo similar, ele disse: 'Não prejudiquem e não sejam prejudicados '”. (ASSADR, 2012, p.259)

83 “"...] o Islã definiu seu significado e o cristalizou por meio de um planejamento social determinado, e tem conseguido incorporar esse planejamento na realidade da vida social, cujas artérias e veias pulsam com o conceito islâmico de justiça". (ASSADR, 2012, p.260) 
Outro autor que destaca a questão da busca da justiça é Siddiqi (1981, p.3), pois para o autor a plena realização da justiça social será dentro de um sistema econômico e social islâmico, quando o homem corrigir sua visão sobre o mundo e se fortalecer moralmente das tentações. Somente num ambiente islâmico é possível ser um verdadeiro muçulmano.

Para Assadr, a forma de justiça social deve atender a dois princípios gerais. $\mathrm{O}$ primeiro é o da "responsabilidade recíproca", que determina ser obrigatório aos muçulmanos ajudar uns aos outros em período de necessidade. O segundo princípio é o do "balanço social", que estabelece que o Estado tem por dever promover a aproximação de pessoas de diferentes padrões sociais.

Através desta responsabilidade recíproca e deste balanço social, o autor irá argumentar como serão materializados os valores islâmicos e assim se terá a justiça social em sua sociedade. Para o autor, a importância da justiça social na economia islâmica à luz destes princípios está claramente refletida na forma com que o Profeta atuava em seu ativismo político em Medina. ${ }^{84}$

$\mathrm{O}$ ativismo político em Medina estabeleceu a irmandade entre os imigrantes que vinham de Meca e as pessoas de Medina. Essa fraternidade baseou o princípio de responsabilidade recíproca com o intuito de materializar os interesses sociais do Islã.

\subsection{Natureza Integrativa da Economia Islâmica}

De acordo com o autor, todos os aspectos da economia islâmica estão integrados e todo o sistema econômico está conectado com as outras entidades religiosas, incluindo as áreas social e política. ${ }^{85}$ Para Assadr, isso é tão importante que, se isolássemos um

\footnotetext{
${ }^{84}$ Segue discurso que Assadr narra para comprovar suas hipóteses: "Ó povo, preparai o bem para vós mesmos, por Deus, um de vós certamente estará confuso, deixado para trás do rebanho, sem um pastor e então seu Senhor dirá: 'Meu Mensageiro não veio a vós e não vos comunicou minha Mensagem? Eu vos agradeci com imensas riquezas e vos favoreci. Porquanto o que preparastes para vós mesmos?' Em seguida, ele olhará à direita e à esquerda e não encontrará nada e então olhará para frente onde nada verá senão o inferno. Assim, se alguém puder salvar-se do fogo, mesmo que seja por dar em caridade mesmo um pedaço de tâmara, que o faça e se não tiver nem mesmo isso, deve se salvar do fogo dizendo algo de bom, pois uma boa ação é recompensada de dez a setecentos vezes mais. Que a benção e a misericórdia de Deus estejam convosco". (ASSADR, 2012, p. 261.)

85 "Para compreender a economia islâmica, não devemos estudá-la como uma parte separada das demais. Por exemplo, não devemos estudar a proibição do Islã à usura ou à permissão da propriedade privada de modo separado de outras partes do plano geral da economia islâmica.
} 
aspecto do outro, provavelmente teríamos problemas na vida econômica. Portanto, o autor enfatiza que os vários aspectos da economia islâmica deveriam ser estudados juntos e que este sistema econômico deve ser compreendido como parte de um sistema geral do Islã. ${ }^{86}$

O sistema econômico islâmico está conectado com o sistema de crenças do Islã ${ }^{87}$, que constitui a fonte básica de crenças para o desenvolvimento das regras islâmicas que permeiam o modelo doutrinário, e por outro lado esta conexão se estende ao sentimento de irmandade. Similarmente, a conexão entre o sistema econômico islâmico e o sistema político é tal que a separação de um do outro pode criar um mal entendido na realização do objetivo em ambos os sistemas.

Essa questão entre a conexão de fato é estabelecida com o intuito de se gerar um balanço na sociedade islâmica através da reciprocidade entre as pessoas, atingindo assim a irmandade entre os irmãos. Ou seja, essa ligação gerará o que o autor coloca como o destino final da humanidade. Por exemplo: o caso da aplicação e estudo da usura, se for realizado sem os outros aspectos da sociedade, poderia ser um problema segundo o autor, mas se estudado e aplicado de forma interconectada, será evidente a visão de Assadr de que isso providenciará claras soluções a problemas sociais.

Similarmente, não é correto estudar a totalidade da economia islâmica como sendo algo independente dos demais aspectos religiosos, o social, o político e todos os outros, e da natureza entre esses aspectos. Devemos compreendê-la como parte de um sistema geral do Islã que organiza diferentes aspectos da vida em sociedade". (ASSADR, 2012, p.264)

${ }^{86}$ Não podemos apresentar aqui todos os aspectos das ligações das diferentes partes da economia islâmica e da ação mutua e interligação existente entre ela e todas as peculiaridades e elementos islâmicos. Iremos descrever aqui apenas alguns pontos: 1- Conexão com a crença, que constitui a provisão básica para a formulação das regras; 2 - Conexão do Islã com o a forma de explanação das coisas, ou seja, na questão da propriedade privada o homem carrega uma obrigação e não autoridade absoluta; 3 - Conexão da economia com o sentimentos e percepções, ou seja, a busca da fraternidade; 4 - Conexão entre a doutrina econômica e a política financeira do Estado, que estabelecerá o equilíbrio social; 5 - Conexão entre a economia islâmica e os sistema político que deve garantir a integridade e retidão de seu governante; 6 - Conexão entre a economia e a eliminação do capital que é produto da usura e os demais princípios islâmicos sobre a parceria, responsabilidade reciproca e o equilíbrio social; 7 - Conexão entre a propriedade privada e a questão do jihad, que irá regular a ação entre muçulmanos e não-muçulmanos em tempos de guerra. (ASSADR, 2012, p.266-268)

87 "O solo ou a base para a sociedade islâmica e sua doutrina social se compõem dos seguintes elementos: Primeiro: a crença, que é a base fundamental no pensamento islâmico, que define a perspectiva essencial do muçulmano para com o mundo. Segundo: os conceitos que refletem o ponto de vista islâmico na descrição das coisas, considerando a perspectiva geral cristalizada pela fé. Terceiro: sentimentos e percepções que o Islã se encarrega de disseminar e promover a categoria de significados, significado (em questão), sendo uma noção islâmica sobre um certo evento, criando no íntimo do muçulmano um sentimento especial sobre este evento e definido sua atitude emocional para com o mesmo". (ASSADR, 2012, p.265) 


\subsection{A Religião Pode Materializar os Interesses Sociais}

De acordo com o autor, a doutrina econômica do Islã é distinta de outras doutrinas econômicas por sua natureza religiosa. A religião, enquanto lida com o homem e cada aspecto de sua vida, deve promover o relacionamento deste com o Criador e buscar sua salvação. É nessa base que o autor argumenta que o homem pode, através de um sistema islâmico religioso, atingir seus objetivos sociais em sua vida diária.

O autor classifica os interesses dos homens como de dois tipos: os interesses naturais e os interesses sociais. ${ }^{88} \mathrm{O}$ primeiro será provido pela própria natureza, ${ }^{89}$ enquanto o outro será atendido pelo sistema social no qual o ser humano vive. Há duas condições básicas para se atender a esses interesses: o homem precisa conhecê-los e, segundo, deve ser incentivado a materializar esses interesses depois de conhecê-los.

Para Assadr, a partir do momento que o homem vai conhecendo seus interesses, procurará mantê-los. Uma vez que esses interesses pessoais não contradizem o interesse de qualquer outro indivíduo, cada pessoa é beneficiada pela busca da satisfação das necessidades e dos desejos. O problema está nos interesses sociais, já que muitas vezes os interesses pessoais não estão de acordo com os interesses sociais. Por exemplo, a garantia do emprego de um trabalhador pode não estar em acordo com os interesses dos grandes empregadores (empresas). Outro exemplo é a nacionalização de terras contra o interesse de quem deseja monopolizá-las.

Com isso, o autor defende que é necessário criarmos um acordo entre essas necessidades pessoais e sociais para a solução do problema. No entanto, este problema não pode ser resolvido pela ciência, como a maioria das pessoas acredita, pois a ciência é apenas um meio para descobrir a realidade, mas não pode fazer uma pessoa escolher

\footnotetext{
88 “[...] a sociedade humana é impelida, pelo estímulo pessoal dos indivíduos que, por sua vez, se encontram ocupados com seus interesses e necessidades, que para todos os indivíduos, é benefício pessoal". (ASSADR, 2012, p.272).

89 "Quando observamos os interesses naturais do homem como, por exemplo, o preparo das ervas para o tratamento da tuberculose, percebemos que ele foi provido de recursos para a obtenção das mesmas. Assim, possui a habilidade intelectual que o capacita a perceber as manifestações da natureza e os benefícios ocultos nela." (ASSADR, 2012, p.272) Aqui o autor reconhece a capacidade do homem em conseguir desenvolver a sua intelectualidade, ele argumentará que ocorre lentamente o desenvolvimento, através de novas experiências e quanto mais essa se desenvolve, mais o homem compreende seus interesses e os benefícios que possam ser extraídos da natureza.
} 
por esta realidade ${ }^{90}$.

Similarmente, Assadr não encontra nenhuma solução lógica para o problema na doutrina marxista, porque para o autor, não há nada científico nela. Além do mais, em sua visão, não é possível para nenhuma configuração social como o governo resolver os problemas sociais através da formulação de leis, porque as autoridades do governo são também homens com interesses pessoais ${ }^{91}$.

Com isso, o autor chega à conclusão de que a única solução para os problemas é a religião. Isso se deve ao fato de que a religião pode oferecer uma solução para o equilíbrio entre os interesses pessoais e sociais. Em sua visão, só a religião pode estabelecer tal acordo. Religião motiva sacrifícios de interesses pessoais para o bem de outros, cria uma nova postura frente à vida, em relação às questões de lucro e perda. Prepara a mente de homens para a questão de perdas, sofrimento, ensina uma maior lição de fraternidade ao homem ${ }^{92}$.

Em conclusão, a religião aqui é vista como necessária à humanidade, pois, de um lado, para o autor, a natureza inculcará no homem o amor por si mesmo e assim criará uma distância entre os interesses pessoais e sociais, isso será chamdo de "solução natural para o problema natural".

Como parte da natureza humana, a religião que realmente pode organizar a vida do homem é unicamente o Islã, sendo que ela poderá encontrar o equilíbrio entre a natureza humana e as necessidades sociais, já que as outras religiões falharam. A idolatria

\footnotetext{
90 “Tal pretensão, de fato, apenas denota ignorância acerca do papel da ciência na vida humana, porque, por mais que esta progrida, constitui somente um meio para se descobrir as realidades objetivas em diferentes campos e para explicar os fatos intelectualmente, refletindo sobre eles com o mais alto grau possível de precisão e profundidade.” (ASSADR, 2012, p.275).

${ }^{91} \mathrm{O}$ autor procura em seu texto fazer uma diferença entre a ideia da descoberta científica e a ação do homem. Em sua ideia, o homem pode descobrir a realidade até certo ponto, mas não o suficiente para transforma-la. Ao que parece há um respeito das ciências exatas, biológicas, mas não a humana.

92 "Quem cometer uma iniquidade, será pago na mesma moeda; por outra, aqueles que praticarem o bem, sendo fiéis, homens ou mulheres, entrarão no Paraíso, onde serão agraciados imensuravelmente" (Corão 40:40) "Quem pratica o bem, o faz em benefício próprio; por outra, quem faz o mal, é em prejuízo seu, porque o teu Senhor não é injusto para com os Seus servos"( Corão 41:46) "Não deveriam o povo de Madina e seus vizinhos beduínos se negar a seguir o Mensageiro de Deus, nem preferir as suas próprias vidas, em detrimento da dele, porque todo o seu sofrimento, devido à sede, fome ou fadiga, pela causa de Deus, todo o dano causado aos incrédulos e todo o dano recebido do inimigo ser-lhes-á registrado como boa ação, porque Deus jamais frustra a recompensa aos benfeitores. Deveriam saber, ainda, que não fazem gasto algum, pequeno ou grande, nem atravessam vale algum, sem que isso lhes seja registrado; em verdade, Deus os recompensará com coisa melhor do que tiverem feito.”( Corão 9:120-121)
} 
e o politeísmo, para Assadr, trouxeram problemas à humanidade. ${ }^{93}$

\subsection{Economia Islâmica Não é Uma Ciência ${ }^{94}$}

Para o autor, há dois lados na economia: o lado científico e o lado doutrinário. $\mathrm{O}$ lado científico se refere à explanação da vida econômica, aos eventos e fenômenos econômicos. Já a doutrina econômica é descrita pelo autor como uma expressão da maneira na qual a sociedade prefere seguir em sua vida econômica para a solução de seus problemas práticos. E no período da escrita do livro, ou seja, o princípio do pensamento islâmico econômico, o autor via somente um lado para a economia islâmica, o doutrinário. Havia em si somente o aspecto das escolhas referentes à busca econômica e não uma interpretação de eventos ${ }^{95}$.

Como parte de um todo, o modelo econômico islâmico organiza a vida. Sua busca é mudar a face de corrupção no mundo e não uma explanação. O autor defende a busca de um método científico, mas argumenta que é necessário que o Islã seja implementado como um todo.

Como se tratava do início do desenvolvimento do modelo, para Assadr ainda não era possível que houvesse uma análise com base na coleta de dados, mas somente com a implementação deste modelo seria possível que se conseguisse o desenvolvimento de

\footnotetext{
93 "Não adorais a Ele, mas a nomes que inventastes, vós e vossos pais, para o que Deus não vos investiu de autoridade alguma. O juízo somente pertence a Deus, que vos ordenou não adorásseis senão a Ele. Tal é a verdadeira religião; porém, a maioria dos humanos o ignora. "(Corão 12:40) 94 "Quando dizemos, sobre o Islã, que ele não é uma ciência, queremos dizer que o Islã é uma religião que garante um chamado à organização da vida econômica do mesmo modo que trata os demais aspectos da existência, e que não é uma ciência do tipo da economia política. Em outras palavras, o Islã significa uma revolução com o intuito de transformar uma realidade corrupta em uma realidade sã, e não uma explicação objetiva sobre esta realidade, então, quando o Islã determina o principio da dupla propriedade, por exemplo, não afirma com isso que explica o fato histórico acerca de um certo estágio da vida da humanidade ou que prefere os resultados das leis naturais da história como o Marxismo o faz quando anuncia as boas novas do princípio da propriedade socialista, como se fosse uma condição inevitável para um certo estágio da história e única explicação para isso". (ASSADR, 2012, p.282)

95“"...] uma ciência pode ser constituída para a economia islâmica - depois que seja analisada como um estudo religioso abrangente - através da análise da estrutura. [...] a explanação científica dos eventos da vida econômica se concentra nas duas matérias seguintes: Um - reunir os eventos econômicos da experiência vivencial e ordena-los cientificamente de tal modo que possam revelar as leis efetivas no campo da existência e suas condições específicas. Dois: iniciar uma pesquisa científica a partir de fatos específicos e deduzir deles, a direção econômica e o curso dos eventos". (ASSADR, 2012, p.283)
} 
forma científica ${ }^{96}$. Não há nenhuma sociedade islâmica que esteja por completo vivendo de acordo com a lei islâmica.

Outro ponto trazido pelo autor é a possibilidade explicar alguns fatos da economia islâmica a partir de determinados pontos religiosos e formular à luz deles um modelo científico para a economia islâmica. No entanto, tal simulação hipotética não poderia ser considerada como científica, porque frequentemente a realidade é diferente da simulação hipotética.

Além disso, os aspectos espirituais e ideológicos de uma sociedade islâmica também têm efeitos na vida econômica das pessoas ${ }^{97}$. Portanto, o autor conclui que a ciência da economia islâmica não pode levá-la a um nascimento real, a menos que seja aplicada em uma sociedade que seja totalmente baseada nos princípios da šari 'ah.

\subsection{O Problema Econômico à Luz do Islã}

De acordo com o autor, todo sistema econômico acredita que há um problema no campo econômico que deve ser combatido. ${ }^{98} \mathrm{O}$ capitalismo acredita que o problema básico são os recursos limitados e esses recursos não se manterão com o desenvolvimento da civilização ${ }^{99}$. Similarmente, o marxismo mantém a visão de que o problema econômico está no desacordo entre as formas de produção e as relações de distribuição ${ }^{100}$.

\footnotetext{
96“Porém, nada semelhante a isso está disponível aos economistas muçulmanos enquanto a economia islâmica permanecer afastada da realidade concreta. Eles não podem tirar proveito de experiências da vida diária sobre a economia islâmica durante a implementação de modo que possam perceber neste processo a natureza das leis que dominam a vida que esteja baseada no Islam". (ASSADR, 2012, p.283)

97 “[...] o elemento espiritual e ideológico ou em outras palavras, o temperamento psicológico da sociedade islâmica, possui uma grande influência no curso da vida econômica. Porém, este temperamento não possui um grau limitado ou uma forma particular que possa ser suposta e sobre a qual diferentes teorias possam se basear". (ASSADR, 2012, p.284)

${ }^{98}$ Mannan $(1995$, p.4) também irá abordar a questão do problema econômico na visão islâmica. "The eternal conflict between multiplicity of wants and the scarcity of means forces us to make a choice between our wants, to fix up a list of priorities and then distribute our resources in such a manner as to be able to secure maximum satisfaction of wants."

99 "O capitalismo acredita que o problema econômico básico seja a diminuição comparativa dos recursos naturais em vista do fato que a natureza é limitada, já que não é possível aumentar a exploração da terra sobre a qual o homem vive, tampouco a quantidade dos vários recursos nas entranhas dela, ao passo que as necessidades do homem continuam crescendo continuamente, com o progresso e a prosperidade da civilização, o que resulta na incapacidade da natureza de satisfazer todas as necessidades em relação a todos os indivíduos". (ASSADR, 2012, p.295) 100 "O Marxismo é de opinião que o problema econômico é sempre o problema da incompatibilidade entre a forma de produção e as relações de distribuição. Assim, quando há
} 
O Islã, de acordo com Assadr, está em desacordo com ambos os sistemas. O problema não está nos recursos naturais e nem na inconsistência entre as formas de produção e as relações de distribuição. O problema real está no homem ${ }^{101}$, pois Deus supriu e suprirá o homem em suas necessidades. Na visão do autor, caso este ande pelo caminho determinado por Ele, não haverá problema com os recursos e o sistema deverá ser regido pelo homem, para que haja um equilíbrio. Sobre esse tema, o Professor Tavakoli comenta:

\begin{abstract}
"Portanto, tudo deve estar em uma harmonia, de modo que este tipo de lição da fundação, se, você tem harmonia ou desarmonia. Adam Smith costumava dizer que tudo estaria em harmonia, sem intervenção. Mas alguns economistas disseram que não é o caso, não há esse tipo de equilibrio, então se você deixar a economia, ele deve ir para um tipo de desequilibrio e que o governo deveria intervir, ok. Assim, Karl Marx está dizendo que o problema é com o tipo de propriedade privada e Adam Snith apenas dizia ... o problema é com o governo, porque o Estado está intervindo. E nunca, entendi, por exemplo, Assadr e algum economista islâmico, dizer que não é a posse o problema e sim a intervenção do Estado. O problema é com as pessoas. Porque quando elas são (...) o risco eles destroem o que mesmo produzem produzindo mais. Eu não sei ... para incentivar as pessoas a consumirem mais, porque eles querem produzir mais, porque eles querem ganhar mais. Então não há esse tipo de responsabilidade que é valida, ok, nós ... os americanos justificamos o consumo quatro vezes mais do que outro tipo de população, só porque estamos no controle do dinheiro internacional, como dólar, ok? E então, a contraparte islâmica tenta criticar a maneira como eles estão introduzindo o problema."
\end{abstract}

Reside, portanto, um problema central no comportamento humano em sua vida prática e sua falta de gratidão para com o que é oferecido por Deus. Sendo assim, o problema econômico está em como o homem vive diariamente. De acordo com o autor, a injustiça no campo econômico ocorre devido à má distribuição de riqueza e à má exploração dos recursos naturais ${ }^{102}$. Quando estes problemas forem resolvidos, haverá uma sociedade mais justa.

incompatibilidade entre ambos, há estabilidade na vida econômica, não importando o sistema social resultante desta adequação". (ASSADR, 2012, p.295)

101 "Deus foi quem criou os céus e a terra e é Quem envia a água do céu, com a qual produz os frutos para o vosso sustento! Submete, para vós os navios que, com a Sua anuência, singram os mares, e submeteu, para vós, os rios. Submeteu, para vós, o sol e a luz, que seguem os seus cursos: submeteu para vós, à noite e o dia. E vos agraciou com tudo quanto Lhe pedistes. E se contardes as mercês de Deus, não podereis enumerá-las. Sabei que o homem é iníqua e ingrata excelência". (Corão 14:32-34)

102 "A injustiça no campo econômico se constituí na má distribuição, ao passo que a ingratidão pelas dádivas divinas se encontra na negligência da exploração da natureza e na atitude negativa em relação a ela". (ASSADR, 2012, p.296) 


\subsection{Distribuição de Riqueza para o Islã}

A primeira riqueza econômica são os recursos naturais do meio ambiente e o problema da distribuição injusta começa com o direito a propriedade privada destes recursos naturais. Na visão do autor, a humanidade tem sofrido muito as mãos do capitalismo e do socialismo referente a este ponto ${ }^{103}$.

Para o autor, o capitalismo foca somente os direitos individuais do homem, ignorando completamente a sociedade, enquanto que o marxismo sacrifica o individuo para o bem social. No entanto, o Islã desenvolve uma estrutura de distribuição para a sociedade islâmica que garante os direitos da pessoa assim como o da sociedade. Para compreender o direito dos recursos naturais no Islã, Assadr desenvolve a teoria de distribuição destes recursos ${ }^{104}$.

Em seu texto, o autor procurará desenvolver a questão criando um quadro de distribuição, no qual ele irá expor os dois instrumentos principais de distribuição em sua visão, os quais serão: o trabalho e a necessidade ${ }^{105}$.

O trabalho, para o autor, é visto como um dever social desempenhado pelo indivíduo para a sociedade e esta o paga garantindo assim também a satisfação de suas necessidades. Para Assadr, o trabalho, no ponto de vista islâmico, não é senão uma causa da propriedade privada ${ }^{106}$ do trabalhador quanto ao resultado de seu trabalho, este tem o

103 “Com respeito aos domínios da distribuição, a humanidade, no curso da história, tem sofrido com diferentes formas de injustiça em razão desta distribuição ser fundamentada, ora numa base puramente individual, ou numa base impessoal. A primeira constitui uma usurpação do direito da comunidade, enquanto a segunda representa o prejuízo dos direitos de um indivíduo." (ASSADR, 2012, p.296)

${ }^{104}$ Importante ressaltar que o autor separa a relação de distribuição da forma de produção. Seu argumento é de que não é possível que a forma de produção possa sofrer uma mudança enquanto as relações sociais mantenham a antiga forma, como também não é possível para as relações sociais precederem a forma de produção em seu desenvolvimento. O Islã rejeita a relação inevitável entre o desenvolvimento da produção e o desenvolvimento do sistema social, para a religião é possível manter um único sistema social, com sua entidade e capacidade, a despeito da passagem do tempo, por mais diferente que a forma da produção possa ser. Para o autor, as forças produtivas não constituem um fator básico na história. Em sua visão, o homem é a força motora da história e não os meios de produção, portanto o sistema econômico é uma parte importante, mas não uma questão determinística no destino dos seres humanos. Ao que parece, há uma visão de sistema estático e não são as formas de produção que irão estabelecer seu sistema social e de distribuição, portanto não há uma relação inevitável.

${ }^{105}$ Como trabalho o autor se refere aos diferentes materiais que extrai os minerais da terra, madeira da árvore, as pérolas dos mares, ou mesmo um pássaro, ou outros recursos e substâncias que se extrai da natureza, por força do trabalho.

106 "Mas, a regra islâmica é:" o trabalho é a causa para a propriedade dos trabalhadores sobre o material e não uma causa para o seu valor" (ASSADR, 2012, p.300). 
direito de possuir os resultados do seu esforço. O homem tem a tendência intrínseca de possuir bens e com isso o direito a possui-los.

Outro ponto levantado é a questão da necessidade. Aqui o autor divide os seres humanos em três grupos ${ }^{107}$, com o intuito de demonstrar que este fato é importante na questão da distribuição de renda, já que para Assadr, nem todos os modelos levarão em consideração os grupos que necessitam de apoio da sociedade, distribuindo a riqueza segundo a capacidade das pessoas.

A questão da distribuição de riqueza está ligada ao trabalho e ao direito a propriedade ${ }^{108}$, já que o trabalho é a causa da propriedade, como dito anteriormente. É o sistema social que determina isso, de acordo com as ideias e interesses adotados. O direito à propriedade sofrerá intervenções. Assadr cita o exemplo da questão do proprietário esbanjar seus bens e o direito de aumentar esses bens por meio da usura. Há limites específicos de acordo com suas teorias.

A propriedade é um instrumento de distribuição secundário, depois do trabalho e da necessidade, na visão do autor o direito a essa propriedade é sobre o uso da terra, como um intermédio para as atividades comerciais ${ }^{109}$, dentro de condições específicas compatíveis com os princípios islâmicos de justiça social.

O autor levanta também a questão da circulação da mercadoria, colocando esta questão como sendo tão importante quanto a produção. A economia fechada ${ }^{110}$ não deixa

\footnotetext{
107 “[...] o primeiro é o que pode, com seus talentos e sua capacidade intelectual e prática prover seu sustento num padrão luxuoso e abastado, o segundo é o que pode trabalhar, porém, aquilo que produz com seu trabalho é apenas suficiente para satisfazer suas necessidades básicas, e o terceiro é o grupo dos que não podem trabalhar em razão de deficiência física, alguma doença mental ou outras causas que paralisam a atividade do homem e o retiram da máquina do trabalho e da produção". (ASSADR, 2012, p.300).

108 "Outra coisa que deduzimos da regra de que o trabalho é a causa da propriedade, é a delimitação do escopo da propriedade privada em concordância com as exigências dessa regra. Pois sendo o trabalho a base essencial da propriedade privada, é necessário que o escopo deste se limite à riqueza na produção ou composição daquilo em que o trabalho venha a intervir, com exceção da riqueza sobre a qual não tenha qualquer influência. Baseado nisso, divide-se a propriedade, segundo sua natureza, tornando-se bem público ou privado". (ASSADR, 2012. p.306)

109 "Com o reconhecimento do Islã do lucro comercial, a propriedade em si se torna um instrumento para o incremento da riqueza por meio da negociação, de acordo com as condições legais e os limites e, por conseguinte, um instrumento secundário da distribuição, limitado pelos valores espirituais e os interesses sociais que o Islã adota”. (ASSADR, 2012, p.309)

${ }^{110}$ Para o autor uma permuta injusta conduz às tragédias de diferentes formas de exploração, por isso devem ser controladas pelas regras islâmicas.
} 
margem para trocas ${ }^{111}$ e o Islã analisa o comércio como uma atividade útil à vida social ${ }^{112}$ e é uma resposta à expressão de demanda e à tendência da produção à especialização e ao progresso.

Mais uma vez, para o autor, o problema residirá no homem, já que a venda que tinha o intuito de compra se transformou em uma venda com o propósito de adquirir capital, e isso o conduziu a uma administração de capital. $\mathrm{O}$ dinheiro mudou a questão das relações, dando outro valor a ela, pois o dinheiro pode ser preservado e acumulado, e o seu acúmulo não acarreta despesas, sendo assim a transação parou de cumprir sua verdadeira função na vida econômica, que seria um meio entre a produção e o consumo e transformou-se em um meio entre a produção e o acúmulo.

Para Assadr, há uma perturbação no equilíbrio entre a oferta e a demanda e a questão do acúmulo do capital tem desempenhado um papel importante nisso, levando os homens não mais à busca da satisfação de suas necessidades, sendo que hoje o dinheiro se tornou um instrumento de monopólio e se tornou um meio para o aumento de riqueza através dos juros que os credores exigem de seus devedores ${ }^{113}$.

Essa acumulação do capital prática é contra as regras islâmicas. O zakāt $t^{114}$ tem

111 "“...] a transação comercial possui duas formas: a primeira, a transação baseada na troca de mercadorias; a segunda, com base no pagamento em dinheiro. A transação baseada na troca de mercadorias é a mais antiga forma de transação comercial. Assim, cada produtor, nas sociedades que adotam a especialização e a divisão do trabalho, costuma obter as mercadorias que não produz trocando as mercadorias excedentes de sua especialização". (ASSADR, 2012, p.311)

112 Para o autor, o comércio deveria ser visto como algo útil à vida social, mas nem sempre será necessário se delimitar regras. "Portanto, alguém que produza $100 \mathrm{~kg}$ de trigo retém metade da produção, por exemplo, para satisfazer suas necessidades e negocia os outros $50 \mathrm{~kg}$ por uma certa quantidade de algodão que seja produzido por outro. Todavia, essa forma de transação não facilita a circulação na vida econômica. Ao contrário, esta se torna mais difícil e complexa com o passar do tempo, já que a especialização aumenta e as necessidades diversificam. [...] as dificuldades são criadas, posto que, em geral as necessidades do comprador e do vendedor são diferentes". (ASSADR, 2012, p.311-312)

113 "O dinheiro obtido com base no lucro da usura começou a se mover furtivamente para os agiotas desde o princípio da era capitalista, quando estes passaram a atrair quantias de dinheiro de diferentes indivíduos seduzindo-os com os juros anuais que os clientes bancários exigiam por seu dinheiro depositado. Com isso, diferentes quantias de dinheiro foram acumuladas nos cofres dos agiotas, ao invés de serem utilizadas na produção útil a sociedade, e por causa desse acúmulo os grandes bancos e as financiadoras se estabelecem e assumiram o controle das rédeas da riqueza no país, desferindo um golpe mortal no equilíbrio da vida econômica". (ASSADR, 2012, p.316) 114 "Zakat - um imposto geral sobre a riqueza dos indivíduos comandados por Deus no Alcorão e intimados pelo Profeta Maomé - é redistributiva na intenção, uma vez que toma daqueles que não têm. Mais importante ainda, zakat representa um componente-chave da economia moral, uma vez que sintetiza uma série de ideias que ajudam a definir que a economia: então noção de que o indivíduo detém a propriedade como um administrador para Deus: a idéia, portanto, que a propriedade deve ser usada para um fim mais elevado, como o sustento e apoio daqueles em 
por base consumir quase todo o dinheiro acumulado. O Islã procurou elaborar um sistema que fizesse com que a riqueza permanecesse nos campos da produção, do comércio e do consumo, procurando eliminar a acumulação.

Sua teoria da distribuição da riqueza é apresentada em dois estágios: a distribuição antes da produção e a distribuição pós-produção.

Enquanto constrói a estrutura conceitual de seu modelo econômico, o autor irá discordar da política econômica referente à questão do capital e o trabalho como parte dos recursos econômicos ${ }^{115}$.

Para o autor, o Islã trata dos problemas da distribuição numa escala maior ${ }^{116}$, que é dividido em quatro categorias: terra, riqueza mineral, a riqueza das águas e outros recursos que vivem no ar, no mar e na terra ${ }^{117}$.

Existem tipos diferentes de terra dentro da sociedade islâmica: a fértil, a morta, a terra islâmica por chamado ou conquista (aldawahah), a terra do alsulh (terra tratada) e outros tipos de terra, como a terra que seus habitantes têm entregado aos muçulmanos sem nenhum ataque, e a terra que os habitantes tem tornado extinta.

A terra naturalmente fértil é de propriedade do Estado ou de propriedade do

posição menos afortunada, do que você mesmo, a idéia de responsabilidade social mútua que garante a integração do indivíduo em uma sociedade verdadeiramente islâmica". (TRIPP, 2006, p.125-126)

115 “A distribuição da riqueza é realizada em dois estágios. Um deles é a distribuição das fontes materiais de produção, e o outro, a distribuição da riqueza produtiva. As fontes de produção são a terra, as matérias-primas, as ferramentas e o maquinário requisitado para a produção de bens e mercadorias heterogêneas para todos os que tomam parte na produção industrial ou agrícola, ou na produção em ambas. Quanto à riqueza produtiva, são os artigos (bens capitais ou fundos fixos) efetuados pelo trabalho humano que resulta de um processo de combinação das fontes materiais de produção. Portanto, há riqueza primária. São as fontes de produção. A riqueza secundária, os artigos e os bens de capital que o homem consegue efetuar por meio do emprego dessas fontes". (ASSADR, 2012, p.378)

${ }^{116} \mathrm{O}$ autor verá como fonte original de produção, a natureza, o capital e o trabalho.

117 "Podemos dividir as fontes de produção no âmbito do Islã (economia islâmica) em várias categorias: i) A Terra: é a mais importante das riquezas naturais, sem a qual é quase impossível para o homem desempenhar qualquer tipo ou natureza de produção. ii) As substâncias primárias contidas na terra (riquezas minerais) como o carvão, enxofre, o petróleo, o ouro, o ferro, etc. iii) Os cursos naturais de água, uma das condições essenciais da vida material do homem, que desempenha um papel importante na produção agrícola e nas comunicações. iv) O restante das riquezas naturais, que consistem nos conteúdos do mar extraídos seja por mergulho ou outros meios, como as pérolas e os corais; e as riquezas naturais que vivem na superfície da terra como os animais e os vegetais; as riquezas difundidas na atmosfera como os pássaros e o oxigênio; ou as fontes naturais, ocultas em (certas) parte da terra, como as cachoeiras que carregam (potencialmente) a energia elétrica que pode ser transmitida através de cabos para quaisquer pontos; e outros estoques semelhantes de riqueza natural”. (ASSADR, 2012, p.383) 
Profeta ou seu legitimo sucessor ${ }^{118}$. O autor irá também debater por diversas páginas a questão das controvérsias, buscando defender a posição islâmica.

Similarmente, a terra morta no período de sua conquista é de propriedade do Estado, já que esta é um anfál ${ }^{119}$ (espólio de guerra). E ainda que as propriedades exclusivas destas terras pertençam ao Estado, as pessoas podem ter direitos especiais de propriedade, se elas investirem seu trabalho para desenvolvê-la. Este direito pode expirar caso o desenvolvimento pare $^{120}$.

A terra muçulmana é aquela que está dentro dos limites de um Estado muçulmano, sem qualquer conflito armado ${ }^{121}$. Essas terras estão divididas em diferentes tipos, são cultivadas e seus habitantes aceitaram o Islã voluntariamente. Segundo o autor, a terra cultivada pertence aos seus habitantes ${ }^{122}$, já que o Islã confere aos muçulmanos que o abraçam voluntariamente o direito à terra e a outros bens.

Quanto às terras que estão mortas, o principio é que estas são de propriedade do Estado, no entanto as pessoas podem adquirir direitos especiais sobre a terra através do

\footnotetext{
${ }^{118} \mathrm{O}$ autor cita oito tradições sobre a questão da propriedade privada para mostrar suas evidências a respeito do tema. A primeira tradição é de Al Halábi, a segunda tradição de Abu Rabi Ash' Shami, a terceira tradição de Hammád, a tradição de Abu Bardah, a tradição de Ahmad Ibn Muhammad Ibn Abi Nasr, o livro de Tarikhu '1 Islamyyah, a tradição de Abu Awn Arth Thaqafi e Al Bujhari. (p. 386-389)

${ }^{119}$ Anfál ou espólio de guerra significa o conjunto de todas aquelas coisas e propriedades que a šari'ah estabeleceu como sendo pertencentes à propriedade do estado pela Palavra de Deus no Livro Sagrado.

120 "De qualquer maneira, sem dúvida o líder do estado (walī 'amru ) possui o direito de impedir a restauração de algumas terras estatais ou fixar o limite de quanto dessas terras terá autorização para que seja restaurado se isso for necessário no interesse público. Extraímos os seguintes pontos da prescrição a respeito da restauração das terras incultas: 1- É considerada uma propriedade do estado. 2- Sua restauração por parte dos indivíduos é válida, a menos que isso tenha sido proibido pela autoridade (walī 'amru). 3- Se um indivíduo restaura a terra que pertence ao estado ele adquire o direito de usufruir dela e impedir que outros o molestem, ( em relação à mesma), mas a terra não se tornará sua propriedade privada. 4- O Imam exigirá do restaurador da terra uma taxa porque é sua propriedade por direito permanente de posse. Ele cobrará essa taxa como custódia pelo benefício do bem público e para a manutenção do equilíbrio social. O Imam também terá o direito de isentar qualquer um do pagamento da taxa sob circunstância definidas. Encontraremos as considerações excepcionais a esse respeito na prática do Profeta”. (ASSADR, 2012, p.406)

121 "As terras tornadas muçulmanas pelo chamado ao Islã como as terras tornadas muçulmanas pela conquista são divididas em terras em que seus habitantes tenham cultivado e seus donos aceitaram o Islã por sua vontade, e as terras que floresceram naturalmente como as florestas e as terras que eram incultas quando foram anexados ao Islã”. (ASSADR, 2012, p.407)

122 "Há um texto de Ash'Shahid Ath 'Thani em seu Al Masalik, que elucida o significado disso. Ele descreve: "Essa terra, que é a terra que um indivíduo tenha restaurado e depois disso se tornou uma terra inculta, era originalmente uma terra livre para que todos utilizassem dela (mubah), quando é deixada sem cultivo, volta a sua posição original e se torna mubah (livre a todos) para sua restauração e cultivo, o que foi a causa da aquisição do direito de sua posse. "Quando a causa cessa, o efeito cessa". (ASSADR, 2012, p.413)
} 
trabalho ${ }^{123}$.

Da mesma forma, as terras cultivadas que acompanham o sultanato islâmico são de propriedade do Estado pela aplicação do espírito de que todas as terras que não tem dono são da anfál ${ }^{124}$.

A terra alsulh (terra tratada), inclui aquelas terras que foram invadidas por muçulmanos com o intuito de capturá-las. Seus habitantes não abraçaram o Islã, mas também não ofereceram resistência armada, estes mantiveram sua religião e ficaram satisfeitos por estar sob um Estado muçulmano ${ }^{125}$. A posse dessas terras depende dos termos e condições do acordo entre os muçulmanos e os habitantes da região.

No caso da terra em que os muçulmanos conseguiram sem qualquer ataque, também pertencem ao Estado Islâmico, e as terras capturadas pelos ataques também serão do Estado, o autor irá se apoiar em textos e tradições para sua tese ${ }^{126}$.

$\mathrm{O}$ segundo tipo de riqueza são os recursos minerais encontrados na terra. $\mathrm{O}$ autor os classifica em dois tipos, baseados em sua localização: visível (alzāhir ${ }^{127}$ ) e invisível $\left(\right.$ albātin $\left.^{128}\right)$.

Os minerais visíveis são os que se consegue facilmente, não requerem trabalho adicional ou processamento a fim de se manifestar, sua condição real e substância mineral revelam-se como sal, óleo, rubi entre outros produtos.

É necessário, no caso dos minerais invisíveis, grande quantidade de esforço e

123“[...] podemos deduzir que a competência de um indivíduo para a terra e seu direito pessoal se estabelecem com base em uma dessas três razões: i)Restauração de uma parte da terra estatal; ii) A entrada no Islã dos habitantes por sua aceitação voluntária do mesmo; iii) A terra que se torna uma do direito da terra às partes em contrato". (ASSADR, 2012, p.410)

124 “Em sua opinião se apoiam nas tradições transmitidas dos Imames nas quais está nas quais está declarado que: 'Toda terra que não tem senhor pertence ao Imam"'. (ASSADR, 2012, p.406)

125 "Essa terra é chamada de "terra de acordo de paz", ou, "terra sob acordo", no jargão jurídico, e tudo que tenha sido firmado nos termos contratuais se aplicará a ela. Se o texto do tratado estabelece que a terra pertence a seus habitantes então a terra será considerada, com base nisso, propriedade deles e a sociedade muçulmana não terá nenhum direito ou reclamação aceitável sobre ela. Se tenha sido acordado em contrato que a terra pertence aos muçulmanos isso se tornará obrigatório e a terra estará sujeita ao princípio da propriedade comum, e o tributo (kharaj) se tornará compulsório em relação a ela". (ASSADR, 2012, p.409)

126 “Tudo quanto Deus concedeu ao Seu Mensageiro, (tirado) dos bens deles (dos Bani Annadhir), não tivestes de fazer galopar cavalo ou camelo algum para conseguir (para transportar). Deus concede aos Seus mensageiros o predomínio sobre quem Lhe apraz, porque Deus é Onipotente". (Corão 59:6)

${ }^{127} \mathrm{O}$ termo alzāhir na linguagem jurídica não é usado em seu sentido literal, que é "aberto", no sentido de que não requer escavação ou labor para alcançar ou ter acesso ao produto.

${ }^{128}$ Quanto aos minerais albātin , na terminologia jurídica é todo mineral que requer esforço e trabalho desenvolvido para revelar suas propriedades, como o ouro e o ferro. 
trabalho a serem despendidos nelrs para que a substância se torne, por exemplo, ouro ou ferro. Esses minerais são submetidos à propriedade comum. Um indivíduo pode tomar quantidade dele para uso de suas necessidades básicas, mas não pode tomar posse das minas naturais ${ }^{129}$.

Ainda segundo a questão dos minerais escondidos, o autor os divide em dois tipos, os que estão sob a superfície da terra e os que estão escondidos em bacias profundas e estes que estão próximo à superfície da terra são de propriedade comum e os indivíduos podem levar se não excederem o limite razoável. Aqui há um grande debate sobre a questão, já que alguns juristas declaram que estes minerais são de propriedade do Estado e nosso autor também mantém essa posição.

$\mathrm{Na}$ questão entre as terras e as minas há o $\bar{l} k t \bar{a}$ (feudo), que seria a concessão do Imã do direito de uma pessoa de trabalhar numa fonte de riqueza natural. O trabalho desta é considerado apto a constituir uma base de apropriação ou aquisição de um direito específico relativo à fonte ${ }^{130}$. A ideia do autor parece ser a de que o $\bar{\imath} k t \bar{a}$ é uma forma de distribuição do trabalho e dos recursos produtivos da natureza. Não é visto como um processo de apropriação, mas um direito e um título que o Imã confere a uma pessoa sobre os recursos primários da natureza, os quais o investem de um direito prioritário a qualquer outra pessoa com intuito produtivo.

Não há um período em si estabelecido, mas o autor defende que o período entre a concessão do $\bar{\imath} k t a \bar{e}$ e o início do trabalho não deve ser longo, pois a pessoa não tem o direito

\footnotetext{
129 "Considerando tudo que os textos jurídicos dizem e as teorias sobre (a posse das) minas, podemos concluir que estas, na opinião jurídica predominante, juntam-se às propriedades comuns e são sujeitas ao princípio da posse comum. Ou seja, nenhum indivíduo terá permissão de se apropriar dos veios e as fontes da mina enquanto estejam nas profundezas da Terra. O direito de propriedade do indivíduo a respeito dos minerais contidos na mina é permitido somente na extensão da dimensão vertical e horizontal do poço da mina. Todavia, isso constituiu um ponto de divergência entre a opinião jurídica prevalecente e a tendência jurídica contrária a isso. $\mathrm{Na}$ opinião prevalecente, o indivíduo recebe o direito de adquirir a mina dentro dos limites no caso a minha de material mineral oculto em estado latente, e na tendência judicial contrária, o indivíduo recebe o direito de posse como sua propriedade apenas da quantidade de material que venha a extrair da mina, e tem o direito prioritário para utiliza-se dela e tirar proveito da escavação sem que ninguém mais o faça". (ASSADR, 2012, p.433)

130 “O Islã não considera īktā uma base para a apropriação por parte do indivíduo dos recursos naturais que o Imam o encarregou, o que seria uma má interpretação de seu caráter como modo de trabalho produtivo e de distribuição de habilidades operacionais, īktā apenas confere ao indivíduo o direito de se responsabilizar a contento das fontes naturais, e esse direito significa que é seu dever trabalhar nessas fontes naturais e que nenhuma outra pessoa terá permissão de impedilo de fazer isso, ou de trabalhar nessas fontes ao invés dele, como foi explicitamente afirmado por Al Allamah Al Hilli no Al Qawa'id: 'īktā significa ikhtisas (um direito exclusivo)"'. (ASSADR, 2012, p.437)
} 
a prolongar o $\bar{\imath} k t \bar{a}$ sem justificativa, e seu atraso em assumir a tarefa se torna um obstáculo para o sucesso $^{131}$.

A monopolização dos recursos é algo preocupante na visão islâmica, a questão da hìm $\bar{a}^{132}$ também é abordada pelo autor. O Islã a proíbe, pois o direito específico neste caso se baseava na questão da dominação, não do trabalho e do esforço.

As fontes de água são classificadas em dois tipos por Assadr: as fontes expostas que Deus criou para o homem na superfície da terra como rios e oceanos e as fontes subterrâneas que o homem alcança com seu esforço tais como poços. O primeiro é uma propriedade comum, denominada de "propriedade partilhada" e o Islã não permite que nenhum indivíduo tome posse como sua propriedade privada, mas permite que a todos os indivíduos usufruam dela. O Islã não daria a ninguém direito sobre o mar e rios, aqui cabe o princípio da propriedade pública.

Outras riquezas naturais entrariam em uma categoria chamada de al mubahatul $a m m a h^{133}$. O Islã estabelece o direito a propriedade privada nas coisas permitidas livremente com base no trabalho para a aquisição da posse.

\subsection{Embasamento Teórico da Distribuição Pré-produção}

O autor defende que há uma minuciosa precisão na "estrutura superior do decreto legislativo islâmico contendo o conjunto de preceitos, segundo o qual a distribuição que precede a distribuição e a regulação dos direitos dos indivíduos", ou seja, Assadr irá

\footnotetext{
${ }^{131}$ Outro ponto a ressaltar é o caso do $\bar{\imath} k t a ̄$ da terra taxada, o autor faz a seguinte declaração: "[...] é a terra taxada que seja considerada uma propriedade da nação, já que não pode ocorrer que conceda a um indivíduo algo dessa terra e o autorize a recolher impostas sobre ela. Esta autorização é exercida pelo governante embora algumas vezes isso se expresse em seu significado histórico, e sem direito ou processo de apropriação que resulte num direito a terra. Ainda que em seu sentido jurídico dentro de limites permitidos não signifique alguma coisa semelhante, mas representa um modo de pagamento ou compensação pelo trabalho que o estado se propõe a remunerar aos indivíduos em troca de serviços públicos prestados." (ASSADR, 2012, p.440)

132 Áreas distantes eram monopolizadas e a questão de eliminar isso foi importante na visão do autor. Levou durante muito tempo a exploração dos recursos naturais. "Era costume das pessoas nos dias da ignorância que alguém quando chegava numa terra fértil fazia com que seu cão latisse numa colina ou planície próxima e então declarava dono de toda a terra até onde o som do latido do cão alcançasse, reivindicando toda a área, em todas as direções que o latido do cão alcançasse. Foi por isso que foi denominado hīmā”. (ASSADR, 2012, p.442)

133 "As coisas franqueadas a todos são aquelas riquezas naturais que todos os indivíduos podem usar livremente, e usufruir delas como também de sua propriedade privada, pois essa permissão geral é uma permissão não somente ao usufruto, mas também dos meios de posse das mesmas". (ASSADR, 2012, p.445)
} 
lançar mão de que os preceitos legais que citamos acima mostram o desenvolvimento de uma teoria pré-produção ${ }^{134}$.

Para o autor, todos os pontos irão abordar que o labor ou trabalho estão no centro da teoria da pré-produção. O trabalho é a única fonte de direito de apropriação sobre as riquezas que rodeiam o homem. Não havendo trabalho, para o Islã, nada é ganho ${ }^{135}$.

Toda essa explicação que parece ter o intuito de fundamentar a diferença entre a apropriação da terra e a apropriação de uma pedra, é que na teoria do Islã há uma diferenciação dos atos de utilização e atividade produtiva dos atos de monopolização e exploração.

Com isso, podemos deduzir dois pontos principais sobre a teoria geral da distribuição antes da produção. O primeiro é que o trabalhador que executa uma tarefa sobre uma riqueza se torna dono do produto deste trabalho, e o segundo é que o prosseguimento do usufruto de qualquer coisa da riqueza natural confere ao indivíduo um direito de proibir a outros tirarem esta riqueza dele conquanto continuar a usufruir dela.

O autor deduz, portanto, que a criação de uma nova utilidade no bem natural e o contínuo aproveitamento dos benefícios que estejam naturalmente armazenados são as duas fontes básicas do direito especial à riqueza natural.

Uma questão importante a ser destacada é a visão de Assadr sobre a interpretação ética da propriedade no Islã, ou seja, a questão da liberação propriedade para o homem é a apresentação, em uma ampla base, da concepção ideal sobre a propriedade, seu papel, seus objetivos e sua tarefa na difusão entre os seres humanos, a fim de que ela influenciasse o homem ${ }^{136}$.

\footnotetext{
${ }^{134}$ Como estrutura superior o autor irá citar a abolição da hīmā, o îktā, as fontes e jazidas como propriedade privada, os oceanos e rios como não pertencentes a ninguém, entre outros pontos.

135 "Na teoria a fonte do direito é o trabalho que esteja ligado às atividades pertencentes à primeira categoria, como o ato de colher lenha da floresta, ou o de transportar pedras de uma terra deserta para restaurar uma terra inculta. Quanto às atividades que se incluem na segunda categoria, não possuem nenhum significado na teoria, pois são manifestações do uso da força e não atividade econômica de utilização ou uso produtivo das fontes e riquezas naturais. E a força não pode se tornar uma fonte de direito especial nem uma justificação suficiente para isso. É com essa base que a teoria geral eliminou a ação de apropriação ou tomada de controle da terra e não estabeleceu qualquer direito especial fundamentado nisso, já que tal ação, na realidade, é uma ação de força e não de utilização ou produção". (ASSADR, 2012, p.456)

${ }^{136}$ É usado aqui o termo alhilāfat para a explicação da base teórica. "alhilāfat acrescenta à propriedade privada a marca da representação e concerte o proprietário num curador da riqueza e um representante em nome de Deus o Altíssimo que é o Senhor e Soberano do mundo e de todas as coisas nele contidas. Essa concepção islâmica da essência da propriedade, quando se torna dominante na mentalidade do proprietário muçulmano passa a ser uma força dirigida ao campo do comportamento, o que torna um dever para ele se comprometer com as instruções e os limites
} 
Sobre a questão de Deus fornecer a uns mais que outros, o autor apenas a coloca como um tipo de teste em relação às dádivas da sociedade e o ponto de sua capacidade para suportar a responsabilidade e de possuir força para o desencargo das importantes obrigações da representação ${ }^{137}$.

Assadr posiciona a questão da propriedade privada, fazendo assim com que o homem repense sua forma de ação na sociedade. Deus ceder ao homem esse direito é a forma de realizar seu objetivo de representação e missão do homem na sociedade ${ }^{138}$.

Esses direitos são limitados, não podendo se estender além do período de vida do dono, já que no Islã o indivíduo não tem direito de decidir o destino de sua propriedade após sua morte ${ }^{139}$. Essa limitação de tempo é considerado um aspecto positivo pelo autor já que limita que novos donos regulam a distribuição da propriedade entre os muçulmanos, sempre refazendo a distribuição antes da pré-produção.

prescritos em nome de Deus o Poderoso, o Glorioso, da mesma maneira que um representante deve sempre realizar os desejos de uma pessoa que o tenha designado para a representação". (ASSADR, 2012, p.478)

137 "Ele foi Quem vos designou legatários na terra e vos elevou uns sobre outros, em hierarquia, para testar-vos com tudo quanto vos agraciou. Teu Senhor é Destro no castigo, conquanto seja Indulgente, Misericordiosíssimo." (Corão 6:165) "Ele foi Quem vos designou como legatários na terra. Mas, quem pecar, o fará em detrimento próprio; porém, quanto aos incrédulos, sua perfídia não lhes acrescentará senão aversão, aos olhos de seu Senhor; e sua perfídia não lhes acrescentará senão perdição." (Corão 35:39) "Não entregueis aos néscios o vosso patrimônio, cujo manejo Deus vos confiou, mas mantende-os, vesti-os e tratai-os humanamente, dirigindo-vos a eles com benevolência." (Corão 4:5) "Teu Senhor é, na Sua Opulência, Misericordiosíssimo; e, se Ele quisesse, far-vos-ia desaparecer e vos suplantaria por outros, tal como vos criou das gerações de outros povos." (Corão 6:133) "E abundante era a sua produção. Ele disse ao seu vizinho: Sou mais rico do que tu e tenho mais poderio. Entrou em seu parreiral num estado (mental) injusto para com a sua alma. Disse: Não creio que (este parreiral) jamais pereça, Como tampouco creio que a Hora chegue! Porém, se retornar ao meu Senhor, serei recompensado com outra dádiva melhor do que esta. Seu vizinho lhe disse, argumentando: Porventura negas Quem te criou, primeiro do pó, e depois de esperma e logo te moldou como homem? Quanto a mim, Deus é meu Senhor e jamais associarei ninguém ao meu Senhor." (Corão 18: 34-38)

138 "No dia em que cada alma se confrontar com todo o bem que tiver feito e com todo o mal que tiver cometido, ansiará para que haja uma grande distância entre ela e ele (o mal). Deus vos exorta a d'Ele vos lembrardes, porque Deus é Compassivo para com os Seus servos." (Corão 3:30) "Todo o bem que façam jamais lhes será desmerecido, porque Deus bem conhecem os que o Temem." (Corão 3:115) "A ti (ó Mensageiro) não cabe guiá-los; porém, Deus guia a quem Lhe apraz. Toda a caridade que fizerdes será em vosso próprio benefício, e não pratiqueis boas ações senão com a aspiração de agradardes a Deus. Sabei que toda caridade que fizerdes vos será recompensada com vantagem, e não sereis injustiçados." (Corão 2:272) "Em verdade, aqueles que lutam contra os Nossos versículos, e tentam frustrá-los, serão os que comparecerão ao castigo." (Corão 34:39)

139 “O Islã, quando estipulou o tempo-limite à propriedade privada confinando-o ao tempo de vida do proprietário e proibindo que se faça um testamento dessa propriedade ou disposição arbitrária quanto ao destino de usa riqueza após seu falecimento, excetuou uma porção de um terço da propriedade deixada, permitindo ao próprio dono decidir a disposição dessa parcela." (ASSADR, 2012, p.487) 


\subsection{Distribuição Pós-produção ${ }^{140}$}

A teoria geral da distribuição da pós-produção confere ao trabalhador o direito privado de propriedade sobre toda riqueza que ele produz através de seu trabalho ${ }^{141}$. Como os meios materiais e as várias ferramentas de que o homem faz uso na operação da produção, se estes meios são de propriedade individual, o dono legítimo destas ferramentas deverá será pago pelo uso disto.

No capitalismo, as ferramentas representam despesas pelo seu uso, assim como o trabalho humano, dentro do processo de produção. Para o Islã, as ferramentas são assistência ao homem, para facilitar esse processo de produção, portanto ele deve ser recompensado por isso. Na visão de Assadr, o papel do homem no capitalismo é que o próprio homem serve à produção e não é um fim ao qual a produção serve. Para o Islã, o homem está em pé de igualdade com todas as forças, como a natureza e o capital, que participam da produção. O homem, para o autor, deve ser o fim e não um meio ${ }^{142}$.

De acordo com o autor, a maior diferença entre o capitalismo e o modelo islâmico está na questão do ponto de vista material, já que no capitalismo, o dono dos meios de produção é o único dono dos produtos produzidos, mas no Islã considera que apenas o trabalho pode dar legitimidade à posse dos produtos produzidos. Somente o trabalhador tem o direito de reclamar os produtos do esforço do seu trabalho. Além do mais, é impensável na economia islâmica alguém empregar outro, oferecer-lhe um arrendamento e ferramentas e somente ele ser dono da produção deste trabalho.

Assadr fará uma ligação com a estrutura superior no início da discussão de sua

\footnotetext{
${ }^{140} \mathrm{Na}$ teoria da pré-produção o autor irá debater a questão do direito legitimo que os indivíduos tem sobre a matéria prima, como um fenômeno da distribuição. Aqui o autor se dirige para o trabalho nas riquezas naturais, já que se transformam em uma riqueza pós-produção.

${ }^{141}$ Como forma de esclarecer mais esta questão, o autor cita Allamah al Hilli " se uma pessoa designar outra como seu representante para cortar madeira na floresta em seu lugar a wikala (representação, intermediação) será nula."(ASSADR, 2012, p.491) Aqui tenta mostrar a questão ligada a essa produção, o próprio trabalho em si.

142 "Pois esta dentro da capacidade do capital contratar trabalhadores para cortar madeira na floresta ou extrair petróleo dos poços, e paga a eles sua remuneração - e isto representa toda a parte do trabalhador de acordo à teoria capitalista de distribuição - e o capital se torna o dono de toda a quantidade de madeira cortada ou mineral extraído pelo trabalhador e da venda disto, ao preço que lhe parecer conveniente, sendo este seu direito. Quanto à teoria islâmica da distribuição, não há lugar para tal gênero de produção, pois o capital nada obtém por meio de exploração do trabalho do corte de madeira ou de extração mineral e a multiplicação das ferramentas necessárias para isto, uma vez que a do material natural confere exclusivamente ao trabalhador o direito de propriedade da madeira por ele cortada ou do minério por ele extraído". (ASSADR, 2012, p.499)
} 
pesquisa. Segundo essa estrutura, não é válido que uma pessoa colha os frutos do trabalho de seu intermediário (waqīl) sobre a matéria prima. Portanto, não é lícito que ele se aproprie da quantidade de madeira que seu waqīl obteve já que ele próprio não trabalhou cortando a madeira, porque a propriedade resulta do trabalho e pertence ao trabalhador.

Outro ponto importante é que o contrato de trabalho é semelhante ao contrato de intermediação, pois em ambos os casos o contratante não se torna dono dos materiais que seu intermediário obtenha da natureza. $\mathrm{O}$ contrato de trabalho remunerado não adquire também propriedade do material natural que seu trabalhador contratado venha a adquirir, pelo simples fato de que ele paga as remunerações pelo trabalho, uma vez que estes materiais não podem se tornar propriedade senão pelo trabalho direto ${ }^{143}$.

O autor também diz que um produtor que se empenha no trabalho para obter materiais da natureza e em sua tarefa usa ferramentas que pertencem a outra pessoa, não receberá nenhuma parcela por tais ferramentas no produto.

De fato, a teoria islâmica da pós-produção confere a um trabalhador a propriedade ou o direito desta propriedade de toda riqueza que produza com seu trabalho sobre ela, apenas quando o material básico em que ela realiza o trabalho de produção seja uma riqueza natural que não pertença a outro ${ }^{144}$. Se a base do material em que o homem realiza seu trabalho for propriedade de outra pessoa se alguém tiver adquirido um direito resultante de alguma das bases que apresentamos da teoria islâmica, então significará que a propriedade ou o direito ao material terá sido consumado numa distribuição prévia, não havendo lugar para que se confira uma propriedade ou direito com base numa nova produção nem para o trabalhador nem para nenhum dos meios de produção que ele empregue nesta nova produção ${ }^{145}$. (ASSADR, 2012, p.505)

143 "Portanto, o produtor se torna dono do material da natureza que ele obtenha não um associado ou um servo deste produto, em razão do fato de que este é o objetivo a que a produção se presta. Ele se apropria de todo o material produzido e as demais forças e meios que servem e participam na produção não estão associadas a ele". (ASSADR, 2012, p.501)

144 "'...] uharah( um pagamento) e o outro é a participação no lucro ou no produto. Um trabalhador tem o direito de exigir uma quantia especifica de dinheiro como um tipo de recompensa pelo trabalho que faz, e também tem o direito de reivindicar uma parcela no lucro ou no produto, entrando num acordo com o dono da propriedade, pois uma porcentagem do lucro ou do produto constituiu sua recompensa por seu trabalho. $\mathrm{O}$ primeiro modo se distingue por um elemento de garantia. É quando o trabalhador se satisfaz em ser recompensado com uma limitada e específica quantia em dinheiro - e a este aplicamos termo, ujrah (recompensa), o dono da propriedade terá de remunerá-lo com esta quantia específica sem considerar os resultados do trabalho e se o que resulta do produto serão ganhos ou perdas". (ASSADR, 2012, p.525)

145 "[...] o material para a produção da qual o homem realiza seu trabalho, quando já não tem dono, a riqueza que o trabalhador produz será inteira e exclusivamente propriedade sua e todas as 
Sendo a questão da propriedade largamente debatida, devemos também destacar o valor de troca, pois a teoria islâmica separa a propriedade do valor de troca e não dá ao produtor direito de propriedade de um material tomando por base o novo valor de troca que o produtor tenha acrescentado ao material, mas, faz do trabalho uma base direta para o direito à propriedade.

$\mathrm{O}$ autor argumenta que separa a propriedade do valor de troca, que o valor dos materiais utilizados na produção de uma mercadoria esteja incluso na formação de seu valor, na proporção de seu consumo. Isto necessariamente não significa que o beneficio do direito de propriedade do que foi produzido seja dado ao dono dos materiais utilizados na produção, pois estes materiais sempre são considerados pela teoria islâmica somente servos do homem, e seu direito é determinado apenas com base nisso ${ }^{146}$.

De acordo com o autor, é válido que um produtor receba de outro homem, sob aluguel, as ferramentas ou materiais de que necessite para seu trabalho e pague ao dono destas ferramentas ou materiais uma compensação previamente acordada. Essa compensação será considerada um aluguel para o dono das ferramentas.

Para Assadr, a responsabilidade do dono da terra no contrato não está limitada ao mero fornecimento da terra e das sementes, mas também se estende às despesas com o solo se este requer adubação. Há aqui, sobre esta temática, diversos tipos de contratos os quais podem ser fechados para a produção e exploração da terra ${ }^{147}$.

outras forças participantes na produção serão consideradas como servas do trabalhador e serão remuneradas por ele e não são consideradas sócias da mercadoria manufaturada, isto é, o produto em pé de igualdade com o homem. Porém, quando o material já pertencer a um indivíduo então continuará, de acordo com o fenômeno da constância da propriedade, sendo propriedade privada de seu dono qualquer que sejam as mudanças que possa sofrer". (ASSADR, 2012, p.507)

146 "[...] que o material usado no ato de produção da nova mercadoria permanece como propriedade de uma pessoa, por conta disso todos os trechos citados afirmam o fato que o material continua como propriedade do seu dono mesmo após sua transformação no processo de produção de uma nova mercadoria". (ASSADR, 2012, p.509)

147 “Al Musáqat é outro tipo de contrato similar ao contrato de parceria na produção. Trata-se de um acordo entre duas pessoas em que uma é dona das árvores ou plantas, e a outra é a pessoa que possui o conhecimento da regra a fim de fazer vingar a produção. Neste contrato o trabalhador se compromete a regar as árvores ou plantas até que produzam. Em troca ele tem parte na produção com o dono com base em porcentagem acordada no contrato. O Islã autoriza tal acordo como foi apresentado em muitos textos jurídicos. Al Mudáribah é um contrato legal no Islã. Nele o trabalhador entra num acordo com o dono do capital a fim de movimentar com ele seu capital e participar no lucro com base em percentagem. Se a pessoa conseguir lucrar com a movimentação do capital o lucro será dividido entre ele e o dono segundo o que foi estabelecido em contrato. Se uma perda é sofrida então esta recairá sobre o dono somente, e para o trabalhador a perda de seu trabalho e de seu esforço será prejuízo suficiente. Não se permite que o dono do capital faça o trabalho pagar por esta perda, pois se o trabalhador der uma caução contra perda sob qualquer condição então o dono não terá direito a nenhum lucro". (ASSADR, 2012, p.514). 
Outro ponto da superestrutura que será debatido de forma mais aprofundada no capítulo três é a questão da cobrança de juros. O empréstimo do dinheiro a juros é proibido no Islã. Isto é, emprestar dinheiro a alguém por um período fixo de tempo e fazer aquele que pediu emprestado devolver no tempo acordado a quantia com juros é harām (proibido) no Islã. Somente o empréstimo sem juros é permissível, portanto, o emprestador pode pedir somente a devolução do dinheiro que tenha emprestado sem qualquer adição a quantia por menor que seja ${ }^{148}$. Há uma restrição do poder do credor, com o intuito de controlar o acúmulo de capital.

Para o autor, ju'ālah é outro ponto importante de distribuição de riqueza. O homem deve se comprometer a pagar adequadamente a execução de uma tarefa. Por exemplo, quando alguém diz que se alguém encontrar um livro que perdeu, essa pessoa ganhará uma recompensa ou que aquele que costurar sua roupa ganhará uma recompensa ${ }^{149}$.

Assadr também irá apresentar a questão da limitação das operações de compra e venda. Uma tradição mencionada pelo autor é o Al Mudaribah, ou seja, se um indivíduo possui mercadorias ou dinheiro é permitido que entre em acordo com um agente para que negocie com sua mercadoria ou capital ou para que compre artigos com seu capital e

\footnotetext{
${ }^{148}$ Um dos pontos mais debatidos a respeito da econômica islâmica, a usura é categoricamente proibida pelo Corão, sendo considerado um pecado capital. Para o Islã a usura não é nem comércio e nem lucro, mas sim um meio de exploração da riqueza. Com esta reavaliação, foi argumentado que a questão seria o desejo de proibir que houvesse uma extorsão, um instrumento de injustiça na sociedade. O que ocorria era que havia um problema na balança de poder que permitia a exploração do necessitado, porém em alguns casos deveria se avaliar o que realmente seria usura ou não, apenas um retorno ao investimento.Com todos os questionamentos a respeito da usura pesquisadores iriam buscar verificar empiricamente os prejuízos que poderiam causar as cobranças de juros e com isso os juristas iriam passar a ressaltar as questões morais implicadas na economia.. "Os que praticam a usura só serão ressuscitados como aquele que foi perturbado por Satanás; isso, porque disseram que a usura é o mesmo que o comércio; no entanto, Deus consente o comércio e veda a usura. Mas, quem tiver recebido uma exortação do seu Senhor e se abstiver, será absolvido pelo passado, e seu julgamento só caberá a Deus. Por outro lado, aqueles que reincidirem, serão condenados ao inferno, onde permanecerão eternamente." (Corão 2:275) "Ó, fiéis, temei a Deus e abandonai o que ainda vos resta da usura, se sois crentes! Mas, se tal acatardes, esperai a hostilidade de Deus e do Seu Mensageiro; porém, se vos arrependerdes, reavereis apenas o vosso capital. Não defraudeis e não sereis defraudados.” (Corão 2:278-279) 149 "A diferença entre o ju'ālah e o contrato baseado em remuneração jurídica está no fato de que se alguém contrata uma pessoa para confeccionar sua roupa, se torna, de acordo com o contrato, o dono do serviço ou o lucro contratado se torna o dono da remuneração especificada no contrato." (ASSADR, 2012, p.517) "No ju'alah é permissível para um comerciante de madeira, por exemplo, declarar sua prontidão a dar a qualquer pessoa fabrique estrados de cama de pedaços de madeira, metade do valor do produto, e de acordo com isto, o trabalhador se torna ligado ao resultado da operação que executa”. (ASSADR, 2012, p.525)
} 
revenda.

\title{
2.12 O Papel do Risco
}

Na teoria da distribuição pós-produção, o autor não admite o risco como um dos fatores para a aquisição do ganho. Não há nenhum gênero de ganho que receba sua justificativa a partir do risco. Segundo Assadr, o risco não é mercadoria que o empreendedor pode oferecer a outro, não é um trabalho que se possa colocar preço, exigir uma compensação ${ }^{150}$. Muitos autores do período contemporâneo se dedicaram a estudar isso, já que está muito presente no sistema capitalista e se choca com a ética islâmica, os valores sociais e a busca pela tranquilidade de uma vida em ordem com o sistema islâmico. Para Mannan (1995, p.357), o risco promove a falta de segurança, ou seja, a falta de equilíbrio na sociedade. A questão da manutenção deste espirito islâmico combinando diversos pontos do sistema econômico é fundamental para seu perfeito funcionamento. Em entrevista com o Professor Tavakali o argumento é claro sobre os riscos:

\begin{abstract}
“Ok, então você está apenas jogando. E o jogo está acontecendo no tipo de sistema monetário recorrente, mercado de capitais. Então, eles estão apostando no preço do petróleo agora, no mercado futuro e de opções, esse tipo de coisas. Ok, e que poderia ser uma fonte de problema é outra coisa que aconteceu em 2008. Exemplo, este tipo de endividamento coloca em segurança o sistema. A diferença está no sistema monetário e do sistema real, aquele que produz este tipo de crise enorme, e o que essa crise desdobra para outros países também, e desestabiliza todo um sistema conectado ... ok, então, talvez existam diferenças, e formas de introduzir o problema que estamos a propor e a solução diferente, e os remédios. E seria também a segunda fonte de problemas. Então, assim que essa base filosófica e, ok, nós poderíamos produzir um ... ou podemos explicar a situação de forma diferente ou do problema e da situação e, em seguida, chegamos a recomendação de política diferente, ok?"
\end{abstract}

Não há uma aceitação do papel do risco no sistema visualizado por Assadr, e isso é algo firme na economia islâmica.

\footnotetext{
150 “[...] o direito do dono do capital ou da mercadoria ao lucro é o resultado da propriedade do material que o agente maneja lucrativamente por meio da venda. É similar ao direito do dono de uma tábua de madeira da qual um estrado de madeira seja manufaturado". (ASSADR, 2012, p.541)
} 


\subsection{A Teoria da Produção}

Para Assadr, existem dois aspectos da atividade de produção: um deles é objetivo, que trata dos meios empregados, a natureza que é implementada e o trabalho dispendido na execução da operação produtiva; o outro aspecto é o subjetivo, que consiste da motivação psicológica, o objetivo almejado com a operação e sua avaliação de acordo com as concepções de justiça adotadas.

Segundo o autor, será o aspecto objetivo que lidará com as ciências físicas, com o intuito de descobrir as leis gerais que controlam os meios da natureza, de modo a tornar possível ao homem exercer controle sobre estas leis, após a identificação e a organização do aspecto objetivo da operação produtiva.

A doutrina está ligada ao aspecto subjetivo, e irá refletir, na visão de Assadr, a contradição entre as sociedades, trazendo um ponto de vista sobre o processo produtivo. E avaliará esse processo com base em suas concepções gerais e seus métodos doutrinários quanto à determinação das motivações e contribuições dos ideais de vida.

No que tange aos desacordos entre os modelos, aqui é o único ponto em que para o autor há uma concordância entre o capitalismo, o marxismo e a doutrina islâmica, que é o crescimento da produção e a utilização da natureza ao limite máximo ${ }^{151}$.

Para o autor, o Islã ordenou à sociedade islâmica a formar sua conduta em conformidade com o princípio do aumento de riqueza e a exploração da natureza a seu limite máximo possível ${ }^{152}$, com a intenção de melhoria da vida do homem na terra, para

151 "Todas as doutrinas do sistema econômico são unânimes sobre a importância desse objetivo e de sua realização por todas as maneiras que estejam em conformidade com a estrutura ideológica de sua respectiva doutrina. De modo semelhante, como resultado de um sistema único de coordenação orgânica da doutrina rejeita-se tudo que não seja compatível com esta estrutura doutrinária. Desde que o princípio de crescimento da produção e a utilização da natureza ao limite máximo é parte de um todo, reage às outras partes em cada doutrina e se conforma de acordo com sua posição e sua ligação com as demais partes componentes. Por exemplo, o capitalismo rejeita qualquer método de crescimento da produção e aumento da riqueza que entre em conflito com seu princípio de liberdade econômica; e o Islã rejeita todos os métodos que não estão de acordo com suas teorias sobre a distribuição e deu ideal de justiça. Todavia, o marxismo acredita que a doutrina não se choca com o crescimento da produção, antes, segue lado a lado com ele, de acordo com seu ponto de vista há uma coordenação inevitável na relação entre a produção e forma de distribuição". (ASSADR, 2012, p.551)

${ }^{152} \mathrm{O}$ autor usa em seu texto uma citação de Mohammad Ibn Abu Bakr: "Ó Servos de Deus! Os tementes adquiriram a posse das boas e efêmeras coisas do mundo e das boas coisas da vida futura. Compartilharam da vida mundana com as pessoas do mundo, porém as pessoas do mundo não compartilharam da vida futura com eles; Deus lhes permitiu terem as coisas mundanas de modo adequado e que fosse suficiente para eles (para as necessidades). Deus, o Poderoso, o 
que fossem supridas suas necessidades. $\mathrm{O}$ aumento da produção leva à prosperidade material, mas ainda sim há limites nessa exploração.

O autor apresentará o que em sua visão seriam os meios que o Islã utiliza para o crescimento da produção. O primeiro deles é o aspecto intelectual, os aspectos doutrinais para a economia são para estimular o homem ao trabalho e à atividade produtiva, com o intuito do aumento da riqueza material. O Islã oferece como meios também as questões morais que permeiam a economia.

Na visão do Profeta, o trabalho era algo importante, já que o homem que trabalha para ganhar seu sustento se torna de maior mérito diante de Deus do que o adorador que não faz nada por preguiça, ou que abandona o trabalho. Estes são vistos como de certa pequenez moral, já que isso é considerado um dos pontos mais importantes e destacados na visão de Assadr $^{153}$.

Outro meio é a questão colocada por Assadr sobre o posicionamento contra os bens materiais que permanecem sem utilização e são impedidos de outros o utilizarem, então retirados do campo do uso produtivo e lucrativo. O Islã incentiva o emprego das máximas forças possíveis da natureza e de suas riquezas na utilização produtiva e no serviço do homem na produtividade que gere lucros e considera a recusa da utilização dos meios produtivos uma ingratidão em relação às dádivas que Deus concede a seus servos.

Outro aspecto é o legislativo, que se refere aos numerosos decretos islâmicos que estão em conformidade com os princípios do crescimento no qual o sistema islâmico da

Glorioso diz: "Dize-lhes: Quem pode proibir as galas de Deus e o desfrutar os bons alimentos que Ele preparou Seus servos? Dize-lhes ainda: estas coisas pertencem aos que creem, durante a vida neste mundo; porém, serão exclusivas dos crentes, no Dia da Ressureição. Assim elucidamos os versiculos aos sensatos." (Alcorão, C.7-V.32) Eles vivem da melhor maneira suas vidas no mundo, comem das melhores coisas. Partilham do mundo com as pessoas mundanas. Comem com eles as coisas puras e lícitas e bebem com eles o que é pro e lícito, se vestem com as melhores roupas que as pessoas mundanas vestem, habitam nas melhores casas e têm as melhores montarias como elas. Gozam dos prazeres do mundo com as pessoas mundanas, e amanhã serão protegidas de Deus, que desejem suas dádivas e lhes será dados o que desejam; suas preces não serão rejeitados e nada serás diminuido de deus quinhão de prazer. Assim, ó servos d Deus aquele que for sensato se empenhará por tais coisas e o fará com temos de Deus. Não há nenhum poder ou força senão em Deus". (ASSADR, 2012, p.552)

153 "Em várias outras tradições o trabalho (para o sustento) é considerado parte da fé. E de diz nelas: "Utilizar de uma propriedade de um modo adequado é uma parte da fé". Em outra tradição do Santo Profeta (S.A.A.S.) se diz que não há nada que um crente semeia ou planta e de que um homem ou um animal se alimenta que não seja escrito em seu registro como uma sadaqah (ato de caridade). [...] Em outra reunião com o Imam, respondendo a alguém que tinha pedido para que orasse a Deus para que lhe desse um meio de sustento, o Imam disse: "Eu não pedirei por ti. Busca isto de alguma maneira como Deus, o Exaltado, pediu para que fizesses." (ASSADR, 2012, p.555) 
economia acredita e que auxiliam em sua adaptação e aplicação prática. Esses princípios estão ligados a doutrinas e aos aspectos subjetivos.

A questão da posse da terra é destacada aqui mais uma vez, pois é inadmissível ao Islã uma terra ociosa. Porém Assadr pontuou que esse poder dado ao wal̄ 'amru não dá poder para que ele ceda a terra a alguém que não esteja apto a torná-la frutífera.

Assadr levanta também a questão da ilegalidade da aquisição de ganho sem trabalho, por exemplo, por meio da entrega de uma terra por arrendamento a outro a um valor além do que o primeiro tenha alugado.

Neste ponto, o autor volta à questão da cobrança de juros, pois um dos pontos abordados pela usura é a questão do capital ser um capital produtivo, contribuindo com sua parcela no empreendimento comercial e industrial da sociedade islâmica.

Para Assadr, a transformação do capital revela dois ganhos: o conflito entre os juros do comércio e indústria e os juros do negócio usurário. Para o autor, a abolição dos juros põe um fim no conflito que existe entre os usurários e a classe mercantil e industrial na sociedade capitalista. Outro ponto abordado é que para o autor, os valores que serão investidos no campo da indústria servirão aos grandes empreendimentos e atividades de longo alcance de modo determinado e com segurança e com a abolição dos juros o dono deve focar o lucro ${ }^{154}$.

Um ponto de destaque no texto de Assadr é a questão das atividades consideradas pelo Islã como não produtivas como a jogatina, a magia, o ilusionismo. A lei islâmica não permite o ganho a partir destes artifícios ${ }^{155}$.

O zakāt entrará também para a questão da circulação e retenção, já que o Islã pró́be o entesouramento do dinheiro. Esse imposto tem por meta a melhor distribuição de renda e que se exaure a riqueza entesourada com a passagem do tempo, pois a

\footnotetext{
154 "Diferente será o caso em uma sociedade em que o sistema de juro domina. Em tal sociedade ele preferirá emprestar seu dinheiro a juros que investir em empreendimentos, pois, o lucro via juros é seguro em todas as circunstâncias. [...] Mas se abolir o sistema de juros e com a transformação do usuário em negociantes, lançando sua sorte no comércio, participando diretamente em vários empreendimentos, satisfarão seus interesses com menos lucro já que não estarão obrigados a abdicar de uma parte em favor do juro. Estarão igualmente satisfeitos ao investirem suas economias, depois de satisfazerem suas necessidades, nos empreendimentos e projetos produtivos e comerciais". (ASSADR, 2012, p.559)

155 "Praticar tais artifícios é desperdício e dispersão da força útil e produtiva do homem, e o dinheiro pago aos praticantes é desperdício que poderia ser convertido num agente do crescimento e do aumento da produção." (ASSADR, 2012, p.559-560) "Não consumais as vossas propriedades em vaidades..." (Corão 2:188)
} 
imposição dele é recorrente a cada ano incidindo em 2,5\% sobre o dinheiro guardado ${ }^{156}$. Assadr defende que a usura é considerada uma apropriação gradual do Tesouro Público, e não deve ser abandonada até que o dinheiro entesourado seja reduzido ${ }^{157}$. Para o autor, ao se impor essa taxa, todos os capitais se dirigem aos campos de atividades econômicas e assim cumprem uma parte positiva na vida econômica da sociedade ${ }^{158}$.

As tradições islâmicas de fato pretendem interditar ao homem que busque o entretenimento e as diversões ociosas e excitantes que possam afastá-lo do caminho divino. Na visão do autor, isso é questão fundamental para a economia já que essas diversões minam a personalidade e o caráter do homem e retiram o vigor da juventude, deixando-o improdutivo.

Outro ponto considerado incentivo à distribuição de renda e um fator importante para a teoria da produção é a questão da herança. Para Assadr, o Islã permite que a riqueza de um indivíduo seja entregue a seus parentes e isso é um aspecto positivo e um incentivo do homem ao trabalho ${ }^{159}$. Qualquer ação que seja considerada um incentivo ao trabalho recebe maior atenção dentro de sua formulação, já que para o autor, uma das questões

156 "O impedimento do acúmulo de riqueza embora esteja diretamente relacionado com a distribuição, também possui uma relação indireta com a produção, pois tal acúmulo leva a seu prejuízo. Quando a riqueza se concentra na mão de poucos, o predomínio da miséria se torna generalizado e as carências se multiplicam num agudo sofrimento. O resultado será que o povo comum estará incapacitado de consumir a quantidade de mercadorias satisfatória para suas necessidades por conta da redução de seu poder de compra. Então, grande quantidade de produtos permanecerá acumulada, não-vendida, a queda dos preços dominará a indústria e o comércio e a produção será suspensa". (ASSADR, 2012, p.564)

${ }^{157} \mathrm{Na}$ concepção de Assadr, o dinheiro por sua natureza é um meio de troca. Segundo o autor o homem o empregou de modo proveitoso na troca para superar as dificuldades da negociação que surgiram da troca direta por produtos. O primeiro papel do dinheiro veio a existir de valor comum como meio de troca. Quando ele começa a ser entesourado gera o desequilíbrio entre oferta e demanda.

158 “"...] a proibição do Islam sobre o entesouramento não é meramente um fenômeno acidental da legislação islâmica, mas sim, um fenômeno expressivo de uma das fontes mais importantes de diferença entre a doutrina econômica do Islam e a doutrina capitalista. Reflete um método pelo qual o Islam foi capaz de livrar-se dos problemas resultantes da anomalia do papel capitalista do dinheiro que leva a graves crises e que ameaça o movimento da produção e perturba continuamente a sociedade capitalista". (ASSADR, 2012, p.560)

159 “"...] encontramos nas regras de herança relativas à distribuição da riqueza e propriedade após a morte, o que incita o homem ao trabalho e o impulsiona ao esforço para aumentar sua riqueza, sua ânsia para o bem estar aqueles que perpetuarão seu nome. Quanto ao aspecto negativo das regras de herança, se refere as que tratam do rompimento da relação do homem com sua propriedade e riqueza após sua morte. Por estas regras, não é permissível que uma pessoa decida o destino sozinho, o destino de sua propriedade. Esta injunção resulta da teoria geral da distribuição da pré-produção e esta relacionada à mesma, como aprendemos anteriormente". (ASSADR, 2012, p.564-565) 
principais para o desenvolvimento econômico é a ação do homem em seu trabalho.

Como fator de impulso também dentro da teoria da produção o autor irá abordar a questão da seguridade social. A questão do suprimento das necessidades do homem de forma a torná-lo hábil ao trabalho é enfatizado no campo da teoria da produção. Porém, a seguridade social ao homem que possui condições físicas e que esteja apto a se dedicar às atividades econômicas é ilícita.

O autor não discorre sobre a questão do consumo, um fator de destaque em sua visão sobre a liberdade do capitalismo. Há uma denúncia clara à extravagância e ao desperdício. Mesmo que em sua visão o homem seja a questão do problema econômico, não haverá um debate mais claro sobre o consumo dos muçulmanos.

A grande diferença apontada na questão dos motivos para a produção dará um maior destaque à discussão entre o modelo capitalista e o modelo islâmico. O significado da riqueza ${ }^{160}$ islâmica será crucial para as motivações no sistema. No que tange ao sistema islâmico, a riqueza não é o principal objetivo da vida, ainda que seja um objetivo importante do sistema. A riqueza material e seu crescimento possuem dois extremos na visão do autor, a busca da riqueza será um meio para um muçulmano desempenhar seu papel de vice-gerência, o homem pode aqui mostrar a elevação do caráter humano em todos os campos, moral e material, sendo que assim estará ajudando sua vida no além.

Para o autor, o Islã garantiu a justiça na distribuição criando um sistema próprio, quando nega a dependência da distribuição em relação à forma de produção, no sentido de não haver uma força da lei natural da história. De acordo com Assadr, o Islã limita a produção à prestação de contas da distribuição em vez de conformar a última às necessidades de produção como determinou a teoria marxista. Os seguintes pontos são

160 "As seguintes tradições podem ser dispostas na primeira delas: a. O Mensageiro de Deus (S.A.A.S.) disse:" Os bens são a principal ajuda ao temos a Deus." b. Atribuído ao Imam Assadeq (A. S.): "O mundo é a melhor ajuda ao Akhirah (vida eterna)". c. Atribuído ao Imam Al Báqer (A.S.): "O mundo é a melhor ajuda para aquele que anseia pela vida eterna". d. Atribuído ao Mensageiro de Deus (S. A. A. S.): "Ó Deus, abençoa-nos e nos faça prosperar nos assuntos do sustento material, não nos separe um do outro. Se não tivéssemos o pão, não teríamos orado, jejuado, cumprido nossas obrigações para com Nosso Senhor”. e. Atribuído ao Imam Assadeq (A.S.): "Não há nenhum bem no homem que não junta dinheiro de modo lícito por meio do qual salvaguarde sua honra, pague suas dividas e cumpra suas obrigações para com seus parentes". f. Um homem disse ao Imam Assadeq (A.S,): "Por Deus, eu busco o mundo e desejo que ele seja dado a mim". O Imam perguntou: "O que desejas fazer com ele?" Ele respondeu: "Desejo satisfazer minhas necessidades, dos meus filhos e dos membros de minha familia". O Imam disse: "Isso não é buscar este mundo, é buscar o mundo do além". g. É declarado na tradição: "Não é um dos nossos aquele que renuncia a este mundo para obter o outro, nem aquele que renuncia ao mundo do além para obter este." (ASSADR, 2012, p.570) 
apresentados: que é direito do trabalhador ficar com o fruto de seu trabalho e o processo de produção que um trabalhador executa é uma fase desta lei geral de distribuição, sendo assim a esfera da produção é a circunstância da aplicação de parte da lei de distribuição ${ }^{161}$ e quando a produção tem seu nível elevado, a dominação do homem sobre a natureza cresce e num raio de ação mais vasto, e ai caberá a regulação rígida.

Para Assadr, cabe ao Estado regular, usando a figura de seu líder, regras que irão permear este sistema de distribuição. Cabe, para o autor, que o Islã estabeleça a justiça social, limitando a liberdade do indivíduo, ou seja, o princípio da interferência estatal é a lei pela qual o Islã assegura a adequação da lei geral de distribuição e sua consonância com suas ideias de justiça.

\subsection{Perspectiva Islâmica Entre a Relação de Produção e Circulação ${ }^{162}$}

Existem duas importantes operações, de acordo com Assadr, que o homem pratica em sua vida social: a operação da produção e a operação da distribuição. No processo de produção, o homem batalha com a natureza, enquanto que no processo de distribuição, o homem está preocupado com as pessoas com quem estabelece certos relacionamentos.

Diferente do Marxismo, que estabelece uma ligação inevitável entre as duas operações ${ }^{163}$, Assadr observa que, no Islã, produção e distribuição são independentes uma

161 "Tomemos, por exemplo, da recuperação e restauração de uma terra abandonada. O homem na época do trabalho manual não era capaz de submeter ao cultivo áreas de terra distantes, Uma vez que a teoria não permite o uso de uma terra senão por conta do trabalho, e quando, antes da era dos instrumentos agrícolas em que não se podia empreender a cultivo com a ajuda de materiais da própria terra senão de forma limitada. O homem não estava capacitado a fazer mau uso da fase de aplicação da lei da distribuição e nem podia se apossar de áreas de imensas extensões de terra, em conformidade com a lei que confere ao restaurador de uma terra inculta o direito de propriedade. Porém, a época das ferramentas agrícolas deu ao homem o poder de restaurar tais áreas e fazer mau uso da fase de aplicação da lei de distribuição. Sob esta circunstância a orientação de aplicação para o propósito que corresponde ao ideal islâmico de justiça inevitável." (ASSADR, 2012, p.577)

162 "Como sabemos, a produção é um processo de evolução da natureza, da matéria natural para uma forma melhor segundo a necessidade humana. A circulação no sentido material significa o transporte ou remoção de algo para outro lugar e no sentido legal significa - e este é o propósito da discussão aqui- todas as operações comerciais realizadas por meio de contratos de troca, venda, etc. Obviamente a circulação no sentido material é uma variação do processo de produção, pois o transporte de uma coisa para outro lugar em muitas ocasiões cria um novo uso e significa evolução de um material para uma forma ou molde melhor de acordo com a necessidade do homem, igualmente ocorre no estado vertical do transporte". (ASSADR, 2012, p.579)

163 "Os marxistas afirmam a existência dessa relação. Acreditam que toda forma de produção pressupõe, segundo a lei da evolução e mudança, um gênero particular de distribuição, consoante a esta forma de produção. Acompanha seu crescimento e mudança evolutiva. Quando a produção 
da outra. Essa segregação existe porque o Islã é visto na vida social como diferentes formas da expressão da necessidade humana, e não o resultado de várias formas de produção. Para o autor o homem é a força motriz da história.

Segundo Assadr, o homem foi criado de tal forma que ele ama a si próprio e, consequentemente, explora todas as coisas ao seu redor a fim de obter o máximo de prazer e conforto. É esta natureza do homem que traz mudança e desenvolvimento nas relações sociais na sociedade.

Sendo assim, o Islã tem se concentrado no cumprimento de todos os tipos de necessidades humanas e Assadr divide as necessidades humanas em tipos: as necessidades sócio-econômicas básicas, que permanecem constantes apesar da mudança em momentos; e situações e necessidades secundárias ${ }^{164}$, que são o resultado de conhecimento, descobertas de novos recursos e poder de produção. O Islã fornece o devido respeito a esses dois tipos de necessidades humanas.

Para o autor, o sistema social tem dois aspectos, o aspecto permanente, que não pode sofrer qualquer alteração, quaisquer que sejam as condições. O lado estável de sistema social islâmico inclui as normas e regulamentos islâmicos para as necessidades básicas do homem, como a necessidade de garantia de meios de subsistência, as necessidades de segurança, necessidades relacionadas com a distribuição da riqueza e aquelas relacionadas a casamento e divórcio e outros previsto no Corão e na Suna ${ }^{165}$.

Assadr declara que seu segundo aspecto, o dinâmico, habilita a autoridade

assume uma nova forma que não se coaduna em seu movimento com as relações de distribuição que a forma anterior impôs. É inevitável que as relações de distribuição deem seu lugar, após um grave conflito, para novas formas de distribuição que, unindo-se a forma dominante de produção auxiliem ao desenvolvimento e a evolução. Assim, o marxismo considera que o sistema de distribuição sempre segue a forma de produção e se adapta à sua necessidade. Essa dependência à forma de produção é uma lei inexorável e imutável da história. A proposição básica na vida do homem é que ele produz e a produção prossegue e aumenta continuamente". (ASSADR, 2012, p.575)

164 "O Islã, para satisfazer as necessidades e exigências básicas de todos os membros da sociedade, torna obrigatório o aumento da produção, para que se produza uma quantidade de mercadoria capaz de satisfazer estas necessidades e exigências num grau suficiente que permita a todo indivíduo ter o necessário. A menos que o nível de suficiência e o limite mínimo da produção aumentem não será válido dirigir as forças aptas para o aumento desse nível a outro campos de produção, pois a própria necessidade desempenha um papel positivo no movimento da produção não importando o equilíbrio econômico e do poder de compra dessa necessidade." (ASSADR, 2012, p.587-588)

165 “[...] o Islã torna obrigatório que a produção social não conduza à extravagância e o desperdício. Extravagância e desperdício são proibidos no Islã, quer seja no gasto pessoal de um indivíduo ou na utilização pública ou no gasto da sociedade no curso do movimento de produção." (ASSADR, 2012, p.588) 
dominante para decidir à luz do aspecto estável tudo o que é melhor para o seu povo, de acordo com os novos tempos e circunstâncias ${ }^{166}$. Desta forma, servem ambos os tipos de necessidades humanas, as necessidades básicas, bem como as necessidades secundárias ${ }^{167}$.

\subsection{O Papel do Estado na Economia}

$\mathrm{Na}$ economia islâmica, o Estado desempenha duas funções importantes: em primeiro lugar, fornece segurança social para o seu povo e, em segundo, mantém o equilíbrio social na sociedade ${ }^{168}$. É possivel perceber que há uma visão de Estado de bemestar social para o autor, talvez não formado da mesma forma em que temos estes conceitos na atualidade.

Os autores islâmicos irão compreender o Estado com um papel maior, não somente o que supre o sentido material, mas cabendo a este Estado também suprir em sentido espiritual e moral ${ }^{169}$.

O Estado, de acordo com Assadr, fornece segurança social em duas fases. $\mathrm{Na}$ primeira fase, oferece diferentes oportunidades de trabalho para o seu povo, para que eles

166 “O Islã permite a interferência do Imam na produção com as seguintes bases de justificação: Primeiro, a fim de capacitar o estado a garantir o limite mínimo de produção da mercadoria necessária e o limite máximo que seja possível se ultrapassar. É evidente que a gestão dos projetos privados em conformidade com a vontade e o capricho de seus donos de maneira não-dirigida centralmente por uma autoridade legal levará a períodos de complicação e concentração da produção expondo-a a extravagância e ao desperdício por um lado e à escassez em relação ao mínimo por outro, é direito do Estado garantir a produção social gerindo seu curso entre esses dois limites de excesso e escassez, supervisionando-a." (ASSADR. 2012, p.588.)

167 “[...] a legislação islâmica concernente à distribuição das matérias primas (riquezas naturais) cria, por natureza, espaço para que o Estado interfira e supervisione toda a vida econômica, uma vez que a legislação a esse respeito faz do trabalho direto uma condição básica para a apropriação sobre as riquezas naturais e a aquisição de algum direito especial de acordo com a declaração jurídica mencionada em algumas estruturas superiores as šari'ah, o que significa a impossibilidade de que em indivíduo estabeleça um grande projeto de investimento sobre a matéria prima ou riquezas naturais, quaisquer que sejam seus recursos, enquanto não adquirir o direito sobre esta matéria prima pelo trabalho direto." (ASSADR, 2012, p.589)

168 "O princípio da responsabilidade pública recíproca é a primeira base do princípio da seguridade social. O Islã a prescreveu aos muçulmanos como uma fardul kifayyah (ato obrigatório). Constitui o auxilio e a manutenção de alguma pessoa a outra e é dever de um muçulmano dentro dos limites de seus recursos e capacidade. Ele deve cumpri-lo da mesma maneira que todos os seus outros deveres". (ASSADR, 2012, p.592)

169 "But the Islamic concept the Welfare State differs fundamentally from the prevailing notion of the same. Because its concept is so comprehensive in nature that the Welfare State in Islam aims at achieving the total welfare of mankind of which economic welfare is merely a part". (Mannan, 1995, p.371) 
possam ganhar seu próprio sustento ${ }^{170}$. No entanto, quando um indivíduo é incapaz de executar o trabalho ou quando o Estado não lhe fornece qualquer oportunidade de trabalho ${ }^{171}$, então vem a segunda fase, em que o estado faz pronta disponibilidade de uma quantidade adequada de dinheiro para que a pessoa possa cumprir suas necessidades básicas $^{172}$.

O autor afirma que a segurança social tem sua base em dois princípios doutrinários da economia islâmica. Um deles é a responsabilidade recíproca pública e o segundo é o direito das sociedades sobre os recursos naturais do Estado. Com base no princípio da responsabilidade recíproca pública, é obrigatório para um muçulmano ajudar seu irmão muçulmano em tempos de necessidade, e essa ajuda é obrigatória, mesmo após o pagamento do zakat ${ }^{173}$.

Assadr enfatiza que um muçulmano não pode deixar outro muçulmano em isolamento se possui potencial para ajudá-lo. Se isso acontecer, então o Estado pode obrigá-lo à força, com base no princípio da responsabilidade pública recíproca, a fornecer suporte e manutenção para os muçulmanos necessitados. No entanto, tal compulsão será confinada somente até a satisfação das necessidades básicas ${ }^{174}$.

170 "Ele foi Quem vos criou tudo quando existe na terra; então, dirigiu Sua vontade até o firmamento do qual fez, ordenadamente, sete céus, porque é Onisciente." (Corão 2:29) “Esse direito significa que todo indivíduo da sociedade tem o direito ao benefício decorrente das riquezas naturais e uma vida honrada por meio disso. Portanto, qualquer um que seja apto a trabalhar em qualquer setor público ou privado, constituirá uma função do Estado proporcionar a ele uma oportunidade de trabalho, dentro os limites de sua capacidade, e aquele que não tiver esta oportunidade ou estiver incapacitado para utilizá-la, disporá do beneficio das riquezas naturais e dos meios de sua subsistência num honrado padrão de vida, o que será responsabilidade do Estado". (ASSADR, 2012, p. 597)

${ }^{171}$ Não só de trabalho, mas Mannan (1995, p.373) irá abordar que deverá implantar o sistema através da área educacional, já que a habilitação irá oferecer as oportunidades de trabalho adequadas ao homem.

172 "Aqui cabe ao Estado satisfazer as necessidades básicas do indivíduo tais como: alimentação, moradia e roupas, e a satisfação dessas necessidades estará junto ao tipo e na quantidade de manutenção do padrão de vida de acordo com as circunstâncias da sociedade muçulmana. De modo idêntico, cabe ao Estado satisfazer todas as necessidades de um indivíduo, além de suas necessidades básicas, necessidades que entram no sentido islâmico de manutenção de acordo com a elevação do padrão de vida da sociedade islâmica". (ASSADR, 2012, p.595)

${ }^{173} \mathrm{O}$ zakāt é o imposto já direcionado pelo Estado para o auxilio, sendo um dos pilares do Islã, mas será colocado por Qtub (2000,p.167) como: "For, in fact, the zakat is the lowest limit of statutory duties on property, and it stands alone only when society does not require any additional income. But when zakat is not enough, Islam need not feel that its hands are tied; on the contrary, it gives the ruler wide power to assign levies on capital- that is to say, forced contributions from capital at a reasonable rate - subject always to the permanent limitations of its own welfare".

174 "Há uma tradição fiel de fonte em Sama'ah que relata que ele perguntou ao Imam Jafar (A.S.): "Há um grupo de pessoas que tem excesso (de riqueza) enquanto seus irmãos se encontram em 
Quanto à segurança social com base no princípio das sociedades do direito sobre os recursos naturais do Estado, o autor observa que a base teórica deste princípio reside na crença islâmica sobre a criação de recursos naturais e que esses recursos foram criados para a sociedade como um todo e não para qualquer seção particular de classe ou grupo ${ }^{175}$.

Assadr chega à conclusão de que todos os indivíduos da sociedade têm o direito de obter os recursos naturais do Estado. No entanto, ao contrário da segurança social com base no princípio da responsabilidade pública recíproca do Estado, baseada no princípio de "povo", o Estado tem direito sobre os recursos naturais e é diretamente responsável pelo suporte e manutenção de seus sujeitos carentes e desamparados.

Ele afirma ainda que o Estado, com base neste princípio, não é apenas responsável para satisfazer as necessidades básicas de seus súditos, mas tem também o dever de estabelecer um padrão mínimo de vida na sociedade e proporcionar facilidades para cada indivíduo até esse padrão de vida. Ele observa que os textos legislativos relativos ao Estado a respeito de responsabilidade direta sobre a segurança social são muito claros em sua ênfase na responsabilidade direta do Estado e sobre o fato de que esta é uma garantia de manutenção. Apesar de se manter o equilíbrio social em uma sociedade islâmica, Assadr afirma que o Islã procede de duas verdades básicas, uma universal e outra doutrinária. Quanto à verdade universal, é a diferença que existe entre os membros individuais da espécie humana quanto às suas diversas aptidões mentais, intelectuais e

severa necessidade e o zakat não lhes é suficiente. Podem comer até se satisfazerem enquanto seus irmãos estão famintos? É uma época dificil". Respondeu o Imam: "Um muçulmano é irmão de outro muçulmano, não será injusto com ele, não o abandonará numa má situação, nem o privará. É dever de um muçulmano se esforço ( no auxílio), manter as relações fraternas, cooperar um com o outro e ser solidário com aqueles que estão em necessidade". Em outra tradição (declara-se que) Imam Jafar Assadeq (A.S.) disse: "Quem quer, dentro os fiéis, que negue a um fiel algo de que esteja necessitando, quando pode dar a ele daquilo que possui, será ressuscitado no Dia do Juizo com sua face enegrecida, cego e com as mãos atadas à seu pescoço. E então será dito: "Este é um fraudador que agiu desonestamente para com Deus e Seu Mensageiro". Em seguida será enviado ao Inferno”. (ASSADR, 2012, p.593)

175 "Tudo quanto Deus concedeu ao Seu Mensageiro, (tirado) dos bens deles (dos Bani Annadhir), não tivestes de fazer galopar cavalo ou camelo algum para conseguir (para transportar). Deus concede aos Seus mensageiros o predomínio sobre quem Lhe apraz, porque Deus é Onipotente. Tudo quanto Deus concedeu(1625) ao Seu Mensageiro, (tomado) dos moradores das cidades (1626), corresponde a Deus, ao Seu Mensageiro e aos seus parentes, aos órfãos, aos necessitados e aos viajantes; isso, para que (as riquezas) não sejam monopolizadas pelos opulentos, dentre vós. Aceitai, pois, o que vos der o Mensageiro, e abstende-vos de tudo quanto ele vos proíba. E temei a Deus, porque Deus é Severíssimo no castigo." (Corão 59:6-7) Os versículos relacionados da surata especificam a função de "fay" e sua parte na sociedade islâmica em sua competência de setor público. Encontramos aqui a declaração da base na qual a ideia de seguridade social se estabelece a base no direito de toda sociedade aos bens naturais (para que as riquezas não sejam monopolizadas pelos opulentos). 
físicas, sendo que essas diferenças são vistas pelo Islã como naturais ${ }^{176}$. Portanto, de acordo com Assadr, não é nem possível para uma teoria realista descartá-la, nem por qualquer ordem social para aboli-la por meio de legislação.

Quanto à segunda verdade da lógica islâmica para o tratamento da questão do equilíbrio social, é lei doutrinal (econômica) da distribuição, que afirma que é o trabalho a base da propriedade privada e de todo e qualquer direito sobre ela, portanto, de acordo com o autor, o Islã incide sobre o padrão de vida e não a parcela da renda entre os membros individuais da sociedade ${ }^{177}$.

O sentido da norma é que a riqueza deve circular entre as pessoas em um grau que iria dar a cada membro individual da sociedade um padrão comum de vida. Isso, entretanto, afirma que Assadr não quer dizer que o Islã ordena criar este estado em um momento, mas que aponta o equilíbrio social do padrão de vida como meta e objetivo que o Estado deve esforçar-se a alcançar dentro dos meios à sua disposição. O Islã procurar facilitar o alcance deste objetivo, colocando pressão no alto padrão de vida, proibindo práticas extravagantes e fornecendo formas e meios ${ }^{178}$ para a elevação de pessoas que vivem um padrão mais baixo de vida. Desta forma, diferentes padrões são trazidos para mais perto um do outro, até se fundirem em um padrão comum.

176 “"...] os indivíduos são diversos no que tange a seus talentos e potencialidades, antes de cada diferença entre eles na ordem de classes da sociedade; com o intuito de explicar as diferenças entre os indivíduos na ordem de classes e na designação de cada indivíduo a um papel particular nessa ordem, com base na diferença de seus talentos naturais e potencialidades; de modo que será uma afirmação errada dizer que um homem é inteligente porque ocupa de senhor na ordem de classe e que um homem é obtuso porque desempenha o papel do servo na ordem de classe, porque para que o segundo ocupe a posição de servo e o primeiro chegue a posição de senhor, a existência de um diferencial entre eles capacite o senhor o outro contente ( com a posição de servo) na distribuição dos papéis é indispensável. Portanto, somos levados afinal à conclusão positiva da designação da causa aos fatores psicológicos de onde surgem as diferenças com respeito as suas peculiaridades e aptidões." (ASSADR, 2012, p.600)

177 “Disso o Islã deduz a declaração efetiva de que o equilíbrio social será um equilíbrio do padrão de vida e não da renda dos indivíduos da sociedade; e o significado de padrão é que o dinheiro deve estar presente e circular entre as pessoas num grau que proporcione a cada indivíduo da sociedade um padrão comum de vida, isto é, a todo indivíduo da sociedade é permitido gozar de sustento num único padrão de vida com a preservação do grau de acordo com o qual os meios de subsistência sejam diferentes dentro de um mesmo padrão de vida. Porém será uma diferença de grau, do padrão de vida e não uma diferença de padrões contraditórios de vida, como os escandalosamente contraditórios padrões de vida existentes na sociedade capitalista." (ASSADR, 2012, p.601)

178 "O essencial desses poderes pode ser apresentado com respeito às seguintes questões: 1.A imposição de tributos permanentes a serem gastos no propósito do equilíbrio social. 2.A obtenção dos setores de propriedade estatal e a dedicação do estado ao investimento lucrativo desses setores com o propósito do equilíbrio social. 3. A natureza dos decretos legislativos do Islã que regulam os diversos campos da vida econômica". (ASSADR, 2012, p.604) 
Para Assadr, além de fazer cumprir as leis da šari'ah, garantindo satisfação das necessidades e mantendo o equilíbrio social, o Estado tem uma função importante de empreender nova legislação para regular e orientar assuntos econômicos da vida deixados de ser regulamentados pela šari 'ah. Esta esfera é aberta à nova legislação, principalmente no tocante às relações entre o homem e a natureza, que é distinta das relações entre os homens, pois essas relações mudam com o conhecimento, a descoberta de novos recursos, capacidade produtiva, etc.

O Islã tem regulamentado a propriedade privada, criando diversas regras, a fim de garantir a justiça e proteger os interesses da sociedade, e cabe ao governo legalmente constituído preencher essa lacuna.

\subsection{O Sistema Bancário Livre de Juros ${ }^{179}$}

\subsubsection{Um Novo Modelo Bancário}

No debate sobre o novo modelo bancário islâmico, sempre a discussão recai sobre a questão da riba (usura). Essa palavra é mencionada muitas vezes no Corão, sempre trazendo uma clara proibição. O tema se torna complicado quando aparece uma diferenciação no hadith entre a riba na-nasi'a e a riba al-fadl. Por essas proibições, diversas instituições do sistema financeiro e legal trazem em suas transações comerciais a regulamentação da lei islâmica.

Riba al-nasi'a é a forma clássica da riba, que ocasiona - como um empréstimo uma soma fixa no montante do dinheiro depois de um período. Riba al-fadl, que ocorre em um contrato de venda, quando existe um aumento nos termos da troca, também é proibido seguindo as prescrições do Profeta. Um específico hadith menciona seis commodities que constituem o objeto da Riba al-fadl ${ }^{180}$.

No sistema moderno bancário, o primeiro tipo de riba (riba na-nasi'a) é a principal fonte de acumulação. Se a riba é definida como usura, então temos um pequeno problema na cobrança de juros sobre as transações da forma bancária convencional. Enquanto a taxa de juros não atinge tetos anormais, que em qualquer caso não são

\footnotetext{
${ }^{179}$ Este capítulo se baseia em uma pesquisa que o autor realiza para o governo do Kuait.

180 “Ouro por ouro, prata por prata, trigo por trigo, cevada por cevada, tâmaras por tâmaras, sal por sal, cada tipo por cada tipo, em mãos [...]"
} 
quantificados, o sistema bancário convencional precisa se adequar à shari'a.

Se o contrário, a riba é estritamente definida como juros, então a maioria das operações feitas pelos bancos convencionais são tratadas como ilegais. Dentro destas definições, um debate sobre a riba tem sido estruturado.

No trabalho de Assadr, vemos sua preocupação com a Riba, seu trabalho em Iqtsaduna e a pesquisa Banca Islâmica livre de juros abordaram essa questão importante em nosso sistema econômico. Na definição propriamente dita, Assadr oferece pouca consideração sobre as diferenças entre riba al-fadl e riba na-nasi'a, evita a discussão e começa com uma condenação direta dos empréstimos a juros.

Riba é juros e isso é haram no Islã, que significa que você empresta dinheiro por um tempo acordado contra a cobrança de juros que o devedor (emprestador) paga quando retorna o dinheiro no tempo acordado. Empréstimo é proibido exceto quando livre de juros. O credor é o único intitulado a retornar seu dinheiro, sem suplemento (aumento). No entanto, um pequeno suplemento deve ser acrescentado. Esta disposição legal é considerada, em sua clareza, sob o Islã, entre as regras necessárias da legislação islâmica.

No livro Iqtsaduna, há uma menção sobre o sistema bancário. Este ponto apenas é tratado superficialmente na ocasião da discussão sobre a produção. Neste ponto, Assadr adiciona alguns argumentos expostos anteriormente por juristas modernos como Rasid $R i d a^{181}$. O argumento essencial é baseado nos encorajamentos sob o esquema da mudaraba de projetos de longos períodos como oposição ao foco de projetos curtos dos modelos capitalistas atraídos pelos juros fixos. No sistema livre de juros, ao contrário do mudaraba, eles não são diretamente afetados pela viabilidade e solidez dos investimentos produtivos.

Mais interessante, o caso da Riba em Iqtsaduna é analisado dos diferentes ângulos e seu impacto no sistema distributivo. Trata-se, por exemplo, nas origens da distinção entre compensação (salário, soldo, ajr) no qual é permitido como compensação financeira no resultado dos empreendimentos econômicos, o lucro, baseado na participação no resultado final. No sistema de Assad, as ferramentas da produção são definidas como as coisas e máquinas usadas na operação produtiva, como uma máquina de fiação e arado. A recompensa é legalmente limitada a apenas um tipo de compensação. Ferramentas de

${ }^{181}$ Rasid Rida foi um grande reformador islâmico que influenciou o desenvolvimento do pensamento islâmico no século XX. De fato, foi um dos grandes expoentes do salafismo, que faz criticas a "seguir cegamente" o Corão. O autor faz duras críticas à tirania e corrupção dos Califas. 
compensação e capital estão opostos.

O capital comercial contrasta com as ferramentas de produção. Não é permitido para o capital expandir na base de compensação (salários) e não é permitido para o dono do capital emprestar dinheiro a juros, por exemplo. Que ele dê o dinheiro para o empresário ('amel) para comercializar e ganhar uma compensação pelo seu trabalho, porque a compensação é caracterizada por certa independência de resultados práticos como um lucro e perda, pois poderia ser classificado como riba ${ }^{182}$.

No entanto, é permitido para o dono do capital ou commodities fazer viável sua propriedade para o empreendedor negociar e ser somente ele responsável pela perda e em caso de lucro dividi-los em uma base de porcentagem. Participação no lucro, assim como a perda, é a única maneira (uslub) legal de abrir para o capital comercial.

O contraste entre o regime legal da terra e as ferramentas de produção de um lado e o dinheiro como capital do outro, aparece como uma grande ponta do sistema legal de distribuição. Da proibição da riba derivam ainda outras regras de Iqtsaduna, no qual o mais importante é a ligação entre a proibição da riba com o lado negativo da outra regra, a proibição no Islã de ganhar dinheiro sem investir trabalho no empreendimento ${ }^{183}$. Então a questão essencial da Riba no processo de distribuição é formulado da seguinte maneira:

182 "5-O Islam tornou ilegal a aquisição de ganho sem trabalho por meio da entrega de uma terra por arrendamento a outrem a um valor mais alto do que o primeiro tenha alugado, adquirindo assim a diferença, esta hipotética situação já foi previamente discutida. É óbvio que a eliminação da parte do intermediário na relação entre o dono da terra e o agricultor que diretamente a cultiva e contribui para a abundância da produção, uma vez que o intermediário não desempenha nenhum papel positivo no processo produtivo, mas vive às custas da produção e não presta nenhum serviço para ela. 6-O Islam pró́be o juro, e aboliu a usura do capital. Com isso, assegurou a transformação deste capital produtivo, contribuindo com sua parcela no empreendimento comercial e industrial na sociedade islâmica. A transformação (do capital) revela dois ganhos para a produção: Um elimina o amargo conflito entre o juro do comércio e indústria e o juro do negocio usurário, porque os capitalistas numa sociedade que crê na instituição da usura, mal conseguem esperar a oportunidade de ouro de quando a necessidade dos comerciantes e dos industriais se torna uma necessidade premente de crescimento, para elevar a taxa de juros e manter a pressão na bolsa deles, exigindo valor mais alto possível.” (ASSADR, 2012, p.558)

183 "Podemos resumir esse princípio à luz da estrutura superior da teoria da seguinte forma: $\mathrm{O}$ trabalhador se apropria do produto de seu trabalho produzido por seu esforço e energia sobre a matéria-prima natural. Este princípio é aplicável a todo o trabalho de utilização de produção que $\mathrm{o}$ individuo executa sobre as fontes naturais e matérias-primas que possam ser obtidas delas sem qualquer diferenciação entre a operação executada para a restauração da terra inculta ou a escavação da mina, ou a extração da água, ou o cultivo da terra naturalmente fértil, ou ainda o emprego da terra como campo de pastagem e criação de gado. Todas essas operações são trabalho e o trabalhador tem o direito de colher os frutos e se apropriar do produto de qualquer atividade que execute sobre as matérias-primas". (ASSADR, Iqtsaduna , 2012, p.460) 
"Por que é possível para o trabalhador ganhar dinheiro na base de participação do lucro e não é possível para tal participação na base da produção? Por que as ferramentas de produção foram impedidas desta maneira de fazer dinheiro quando o dono do capital comercial ou da terra pode ganhar dinheiro desta maneira?" (ASSADR, 2012, p.568)

A resposta pode ser buscada no esquema islâmico de distribuição pré-produção: "O dono da terra, no contrato de muzara'a, o proprietário do capital, no contrato de mudaraba, em que é permitida a divisão do lucro (no capital ou na terra) é, na realidade, o dono do material que os trabalhadores usam (mumarasa)". Sob o princípio de permanência da propriedade, o trabalho, no caso da terra e do capital, armazena, mas para Assadr, este não estaria armazenado, os donos da ferramenta têm meramente o direito de deixar usar, assim como uma pessoa dá a outra pessoa sua rede de pesca. Os juristas não têm permitido o direito de dividir o produto com os donos da ferramenta. $\mathrm{O}$ único direito do dono da rede de pesca ou da ferramenta de produção é imediato e toma a forma legal de compensação no trabalho, resultante do uso de uma ferramenta produtiva ${ }^{184}$.

Em Iqtsaduna, não é tão claro e significativo o trabalho de Assadr sobre o sistema financeiro, mas o autor aborda o tema na sua pesquisa para o governo do Kuait, criando um esquema mais claro e amplo sobre o assunto.

A questão da riba é complexa e tem um tom negativo no sistema financeiro islâmico, sendo muito criticado por alguns economistas de ordem liberal. De fato, isso é compreensível, pois dentro do sistema financeiro internacional há uma grande preocupação com a mobilização de capital e com a liquidez. O boom do petróleo mudou a configuração da circulação de dinheiro radicalmente e houve uma grande preocupação no mundo árabe e islâmico de como utilizar o petrodólar sem se desligar da lei islâmica e, assim, a questão da Riba emergiu novamente no cenário.

A premissa sempre foi de que a riba (que significa os juros - empréstimos por juros) é a espinha dorsal das operações bancárias e poderia não ser aceita no sistema, não tornaria possível que o sistema funcionasse de forma adequada a circular o capital no mercado. Para Assadr, a resposta foi clara: o contrato de mudaraba deveria substituir o empréstimo e o depósito por juros. Como o sistema financeiro é algo complexo, era necessário não só obedecer à lei islâmica com o sistema, mas criar toda uma estrutura interna e também planejar as várias operações financeiras.

\footnotetext{
${ }^{184}$ Essa distribuição antes da produção é ricamente abordada em iqtsaduna como explicando no começo deste capítulo. (Cf. ASSADR, Iqtsaduna, 2012, p.570)
} 
Uma das preocupações de Assadr é a busca da definição da Riba. No apêndice ${ }^{185}$ do livro, o autor tenta traçar, do ponto jurisprudencial, vários argumentos legais que tentam transformar juros em uma forma legitimada de lucro e no desenvolvimento deste de maneira aceitável.

Assadr parecia muito incomodado com as várias desculpas que eram travadas para a cobrança de juros nas transações e buscava enfraquecer os argumentos sistematicamente. Uma justificação legal é baseada na distinção feita na operação de empréstimos, entre o dinheiro no qual é feito e a operação de empréstimo em si. Sob esta justificação, se o juro é cobrado sobre o dinheiro como um objeto do empréstimo, é riba. Se, no entanto, é anexada na operação em si, se torna jua'la sob a lei islâmica ${ }^{186}$.

O autor estabelece exemplo em sua pesquisa, argumentando que é permitido pela lei islâmica a jua'la, pois uma pessoa pode oferecer uma recompensa para o propósito de outra pessoa, legitimando sua ação ${ }^{187}$. Por exemplo, uma pessoa pode oferecer uma recompensa para outra que procura por seu filho perdido. Na jua'la, a justificação dos juros ocorre na forma de que este é cobrado como uma taxa na operação e não sobre o dinheiro do empréstimo. Mas para Assadr o conceito ainda está mal colocado ou mal usado pelas empresas, porque deveria operar usando apenas o trabalho e não dinheiro ${ }^{188}$.

De um ponto de vista mais amplo, mesmo se supormos que a intenção foi uma

\footnotetext{
${ }^{185}$ Islamic Free Banking (2011, p.164-183)

${ }^{186}$ A definição de jua'la é dada em Iqtsaduna (ASSADR, 2012,p.546).

187 "These are the currency (notes) which the issuing agency makes provision that gold of so much value may be giving on demand. There may be given on demand. There may be two interpretation for it: (a) The regular provision of giving gold to the extend of its value by the issuing agency may be regarded as a surety due to which gains confidence due to the credibility of the issuing agency. (b) The aind of provision by the issuing agency might be that it has regarded as itself liable (occupied by the liability) with the currency note instead of becoming valued one becomes a certificate to the effect that issuing agency is indebted. The difference the two interpretations is very much clear. As per the first interpretations, the agency issuing notes takes responsibility of giving gold against it on demand, the note, if giving the price of something or against some service, means liability of gold against it and the note has been made a certificate to this effect. The issuing agency is since indebted to the seller or to one rendering service. If its seller buys something against the note, it would not be a purchase against a note but against its object, gold which is established as liability for the issuing agency with the note having position as a certificate for it. Its actual positons is not different from other certificates. It is also a type of certificate only. But it is not so as per the second interpretation. According to the interpretation, the issuing agency if gives note as a price or as a recompense for some service, as if, pays the price of the material or the right of the service thought the note and makes no liability for any debt against her but the note. The note has got value only due to the credibility the issuing agency enjoys among the people and because of the promise she has given to give gold. (Islamic Free Banking, 2011,p.166-167)

${ }^{188}$ Interest Free Banking, Appendix. 2011, p.237-242.
} 
recompensa à operação de empréstimo, o elemento essencial da jua'la está indeterminado. O dinheiro da jua'la deve ser apenas dinheiro de recompensa por trabalho, não pode ser dinheiro recompensando dinheiro.

\subsubsection{Estrutura da Banca Livre de Juros}

O protótipo do Banco Livre de Juros é vital para a batalha ideológica do Islã. A ideia é de que alguns sacríficos deverão ser feitos para se levar a mensagem islâmica e a preparação para salvar as comunidades e suas instituições do estado de descrença ${ }^{189}$. Para acabar com o mundo da riba, o primeiro princípio necessário é a ênfase no elemento do trabalho humano como um recurso de rendimento, como oposição ao elemento do capital nas atividades bancárias. Ao passo que o banco exercita sua atividade em sua qualidade de pessoa capitalista, o banco livre de juros insiste na sua qualidade de trabalhador. Essa é ênfase do banco livre de juros no rendimento como um salário por trabalho, e no aumento dos lucros baseando-se nestes rendimentos.

Nesse esquema, nosso autor admite uma exceção, quando o banco livre de juros lida com as instituições convencionais trabalhando na base de juros. Enquanto se refreia de emprestar dinheiro contra juros, o banco livre de juros pode ceder em depositar nos bancos que pertencem a pessoas que não acreditam no Islã, ou em bancos que não adotam o Islã como um sistema de governo ${ }^{190}$.

Defende aqui sua posição em dois argumentos: 1 - com um posicionamento realista, Assadr reconhece que a existência dos bancos convencionais leva à necessidade da banca livre de juros encontrar um sistema com práticas injustas de competição. Portanto, deverá se adaptar; 2 - legalmente tem-se autorizado a prática da riba para não

\footnotetext{
189 “Os mandamentos islâmicos são obrigados a ser adotados por completo e a obrigação de todo muçulmanos é implementa-los por completo na sociedade. Se em um estágio, uma pessoa tornase desamparada, isso não quer dizer que a necessidade de aplicar o resto das regras islâmicas cessa. Será no entanto necessária e terá de se preocupar em aplicar as regras e quanto possível." (Islamic Free Banking, 2011, p.12-13)

190 "The theory of interest free banking in the situation will be not easy to apply while it will be easier for it to explore better means for the application, as all the means are under control of aliens ( to Islam) and the 'interest' system rules over the society. Hence even an Islamic bank is forced to adopted, for its existence such a method of working that could provide the means of existence in the atmosphere on the ground and could keep connection with the other bank following interest system." (Idem, p.13)
} 
crentes, permitindo que estes tenham o lucro deste sistema ${ }^{191}$.

Depois de apresentar suas argumentações, Assadr introduz sua discussão a respeito de um banco islâmico que estabelece alguns destes parâmetros escolhidos para seu estudo. Em primeiro lugar, o autor explica sobre a questão do banco islâmico operando em um ambiente islâmico, onde toda a riba é proibida, e um banco islâmico operando em uma competição com instituições baseadas nos juros.

Segundo professor Hadi Arbabi, se reconhece que as relações institucionais podem, muitas vezes, ser difíceis, mas é possível solucionar isso:

\begin{abstract}
“"Na verdade, há alguns conflitos entre essas duas culturas, diferentes culturas. Sim. Mas, ao nível das instituições e das regras entre ... interacção entre as diferentes instituições, não é tamanha a dificuldade enfrentada. Existem algumas regras na cultura islâmica, talvez ... Reciprocidade ... Essa reciprocidade de modo que o banco islâmico pode tomar estes regras para a interação entre o banco e a gestão. No outro lado, assim que a competição entre o banco de musselina, entre eles, limita a potencialidade das crises. A competição entre um banco não económico e o euro internacional, torná-o longe da cobiça especulativa. Mas, se houver qualquer competição entre eles, isso será quebrada."
\end{abstract}

Devemos lembrar também que no período de escrita de sua pesquisa para o governo do Kuait (1969), o autor pensava apenas no segundo modelo, a questão de ter que lidar com os bancos tradicionais. Segundo, o autor destaca o princípio geral que explica todo o seu sistema proposto em Iqtsaduna e que estabelece a forma de lucro em um banco islâmico. A ênfase não é na força do capital em gerar o salário, mas o poder de criação de riqueza do trabalho humano.

O autor reconhece que não pode evitar o relacionamento com os bancos convencionais. Este seu realismo é bem fundamento no Islã, de uma perspectiva histórica e econômica. Visando o lado econômico, o protótipo do banco islâmico é baseado em seu papel como mediador (intermediário, wasit) entre os depositantes (investidores) e os empreendedores. Do ponto de vista legal, as operações bancárias são geralmente constituídas por dois relacionamentos legais e independentes.

191 "There are three conditions for success in the search. Without taking these condition into consideration, a correct formula cannot be evolved: (1) The new banking should not be against the Islam Commandments. (2) The banking should have so much capability that it should be successful while living in the worst type of the society and interest ridden community. In its course, there should not developed such a situation that the religious from comes in collision with the present system and it has no chance to progress. " (Islamic Free Banking, 2011, p.13-14) 
O banco aqui é o devedor dos depositantes e o credor dos empreendedores. No banco convencional, entretanto, o banco não opera legalmente como um intermediário, mas como uma parte completa das transações, a ligação entre, por um lado, o conjunto de fundos constituído pelo capital, depósitos e empréstimos para negócios.

Como um devedor dos depósitos, o banco convencional paga a eles juros sob os depósitos que não estão sob demanda e como um credor para os investidores, o banco recebe juros altos. Mas o regime de depósitos e empréstimos associados com a riba é proibido no Islã. Sendo assim, Assadr propõe uma alternativa: a separação dos depósitos fixos (tempo, termo) dos depósitos moveis (correntes, demanda) ${ }^{192}$.

Diferente do banco tradicional, que ignora seu papel econômico como um intermediário e serve de conexão entre depósitos e empréstimos, a teoria do banco islâmico proposta por Assadr melhora este papel e estabelece uma correspondência entre os recursos do banco (capital e depósitos) e os investimentos do banco em empréstimos. Por classificar os depósitos como fixos e móveis, a teoria é principalmente direcionada a uma posição do banco com um intermediário para depósitos a longo termo e empréstimos.

O sistema bancário visualizado e descrito por Assadr hoje é visto como um sistema que lida com a "economia real" ou seja, lida com os problemas reais da sociedade islâmica, como comentado pelo Dr. Seyed Hadi Arbabi:

\begin{abstract}
"O banco islâmico é uma instituição para a sociedade. Toda sociedade necessita de um sistema adequado para si. Assim o intuito que o compõe serve ao proposito. Mas, no mundo islâmico, existem algumas regras, para a interação entre os mulçumanos e outras pessoas nãomulçumanos, isso gera certo atrito pois são diversos entraves a serem superados"
\end{abstract}

\footnotetext{
192 "The interest free banking system will be discussed in two stages. 1. Basic points if discussion is to find out the way that when adopted might cause salvation of the interest free banking from the trading interest. This trading in interest is to take profit (interest) on depositing money in modern day's bank and to give interest on taking loan that has given rise to the confrontation and conflict between Islamic and non-Islamic bank. To get rid of trading in interest and the conflict between the two types of the banks, we must necessarily evolve a formula by which such a relation should be set up between the depositors of money and the traders could salvage from the present system of taking interest on deposit and giving interest on taken loans. By presenting the details of basic functions, services and facilities of the present days bank, it would be expressed what opinion, based on the Islamic laws, is about problem and what behavior an interest free bank should adopt in the matters. The problems of deposits in the interest banking come under "income" while the problems of lending money and taking loan come under "expenditure". (Islamic Free Banking, 2011, p. 21)
} 
A intenção sempre foi resolver os problemas para os muçulmanos. O principal tema deste trabalho de Assadr diz respeito às atividades bancárias, utilizando este banco como um intermediário entre os depositantes e os investidores, para depósitos de longo termo.

\subsubsection{Depositantes e Investidores}

A principal operação do banco é a intermediação entre os investidores e os depositantes, chamada de mudaraba, também traduzida na literatura islâmica como “parceria para ganhos e perdas". O autor oferece sua própria definição de $m u d a r a b a^{193}$ :

"O significado de mudaraba na jurisprudência islâmica é completamente diferente dos negócios/comércio na economia moderna. O mudhariba, na jurisprudência islâmica, é o acordo particular que é feito entre o proprietário do dinheiro e o comerciante com as condições que este faça negócios por comissão por tirar o dinheiro do proprietário (financiador/investidor), portanto o dinheiro pertence a uma parte e o trabalho a outra, enquanto que o lucro deve ser dividido por ambas as partes de acordo com uma porcentagem respectiva".

As três partes da mudaraba são o depositante (mudarib), o empresário (mudarab) ou agente ('amel) e o banco, que é o intermediário entre o depositante e o empresário, assim como o agente do dono do capital que o deposita em seus cofres.

Entre as tarefas do depositante na banca sem juros, Assadr descreve dois papéis: primeiramente o depositante não pode retirar seu dinheiro antes de seis meses e deve acordar com os princípios da mudaraba. De fato, o depósito não precisa estar ligado a nenhuma transação especial, pequenos depósitos serão aceitos para ampliar o montante operacional global dos bancos.

Uma vez que o dinheiro é depositado no banco, o depositante detém a propriedade do montante, porém, neste montante serão adicionados outros depósitos que constituem o capital investido nos negócios (projetos) em que trabalharão.

O depósito é benéfico para o depositante de várias formas. Primeiramente deve ser garantido pelo banco. O investidor não deve ser questionado na garantia do depósito nos termos da mudaraba, porém não existe regra prevenindo o banco, como uma terceira

\footnotetext{
${ }^{193}$ O autor usa diversas paginas de sua pesquisa na explicação da questão da mudhariba, procurando expressar as relações bancárias no caso de depósitos fixo. (Islamic Free bankinp,2011, p.31-32)
} 
parte, de oferecer suas próprias garantias ao depositante ${ }^{194}$. Ao invés de um retorno fixo do seu dinheiro, como o banco convencional, o depositante recebe uma porcentagem dos lucros adquiridos pelo investimento. Desta forma, o retorno é proporcionado pela lucratividade ${ }^{195}$.

Outra vantagem do depositante apresentada por Assadr é a possibilidade de retirar seu depósito, desde que estes sejam depósitos por tempo ou fixos. O banco pode regulálos de forma a dar flexibilidade aos depositantes no direito de retirada. Neste esquema, o depositante poderia ser capaz de retirar parte de seus montantes quando de seu desejo, desde que todos os depositantes não retirem seus montantes ao mesmo tempo. Em sua análise, o autor oferece diversas formas de melhorar a flexibilidade nesse processo de retirada $^{196}$.

Neste processo, o banco não é parte integral na transação da muḍārbat, é um intermediário entre as duas partes fundamentais, o depositante e o investidor. $\mathrm{O}$ banco tem direitos e obrigações especiais descritas por Assadr. O banco recebe a ju'ala (taxa,

194 "The first member of mudhariba in banking appears in form of financer/investor. Financer means all those people with whose money the banking business is run. In the other words, it may be put like it that ad apparent difference between the interest bound bank and the interest-free bank is in that the money is taken from the depositors as on loan and then after taking it in its ownership, the bank does business while it is not so in interest-free bank wherein the money remains in the ownership of its owner and the bank, taking money from the depositors with their permission, does business in capacity of a trustee only. It is something different here that the deposits are not kept separated but are mixed up with the permission of the depositors (owners of the money), thus making the ownership of the whole money joint and collective. The money is collective and the owner is joint. In each and every portion of the money there is, right of every depositor in proportion of his respective share money (deposit) and he is regarded as owner of his respective portion of money. Even all the new money pouring in would be put into the ocean of the money with its respective owner regarded as rightful owner of the respective proportional share of collective money.[...] According to the study and research, the following things may attract people to deposit their money in the bank: (i) Security of the deposit. The requisites of the interest-bound banks is that they take money as on loan so they are its surely. (ii) Gain it is the interest that the bank give (to the depositors) on the loans. (iii)Power to the depositors. The depositors may withdraw his Money or part $f$ it as and when he wishes as per the agreement." (Islamic Free Banking,2011,p.35-39)

${ }^{195} \mathrm{O}$ autor descreve em várias paginas a questão da lucratividade e da atratividade para os Bancos Islâmicos. Aqui Assadr irá reconhecer que é necessário desenvolver mais a banca islâmica.

196 "It is also of the interest-bound bank's particularities that every depositor has option to withdraw his money in certain period and may take benefit out his money under specified conditions as when he desires. It is needed that such facility should also be provided in the interest-free bank and the depositor should also be given power to withdraw their money, though the task is extremely difficulty at this point. The money is invested in different enterprises and it is not just a sort of a debt that might be advanced or withdrawn as and when wishes. Even the interest-free bank may possibly fix a period of six months from the date of money is deposited in the bank, after which the depositor could exercise his option to withdraw the money. He shall not have a such option before the period is over." (Islamic Free Banking, 2011, p.44) 
comissão, remuneração) por sua intermediação de duas formas. A primeira é um salário fixo (ajr thabet) por seu trabalho. No banco convencional, o trabalho do banco é recompensando pela diferença entre os juros dados ao depositante e o juros recebidos pelo empréstimo. Porém, na forma islâmica, como o banco opera de forma diferente, o autor conclui que, já que o salário não é a diferença entre os juros, o banco deve estabelecer um salário alto ${ }^{197}$.

O banco islâmico amplia o montante de dinheiro disponível para investimento com partes de seu próprio capital com que é considerado possível investir nos depósitos em conta corrente. No caso, o banco se torna mudarib também e terá direito à parte do dinheiro garantido e retorno constituído pelo valor do risco do capital. No entanto, o banco investe o dinheiro de seus depositantes antes de usar seu próprio dinheiro.

O empresário, tanto no banco convencional quanto no banco islâmico, é o que possui o direito aos lucros do empreendimento no qual ele está comprometido. O banco deve cobrir a perda do capital no sistema islâmico. A sobrevivência do Banco islâmico depende obviamente da lucratividade no projeto. Assadr assim argumenta que para se manter o banco, deve-se procurar trabalhar com pessoas honestas e capazes e procurar analisar com certo escrutínio cada projeto, supervisionando os grandes projetos diretamente.

O status legal dos depósitos móveis, os quais geralmente constituem a conta corrente, é muito mais simples que o outro que caracteriza os depósitos fixos, porque há a incerteza e a instabilidade destes depósitos, que podem ser retirados na demanda do

197 “(a) It takes fixed labor charges, to be decided by expected difference of the money between that to be advanced to the businessmen and that to be withdrawn by the depositors. The excessive portion, given to the investors in promoting deposits in the interest free bank, might be separated out. If seen separately out, it is this excess money being the difference between the interest charged on one hand and that given on the other hand which forms the primacy source of income (gain) for and 'interest' bank. This quantity of the profit is not enough for the interest-free bank and this difference only won't be sufficient to support life of the bank since there is a basic difference between the 'interest' bank and interest free bank. All the liability of the deposit goes to the bank which is responsible for the money of the financers (depositors) while it is not so for the interest. This quality of the profit is not enough for the interest-free bank and this difference only won't be sufficient to support life of the bank since there is a basic difference between the 'interest' bank and interest free bank. All the liability of the deposit goes to the bank which is responsible for the money of the financiers (depositors) while it is not so for the interest bank where businessmen who take money as loans from the bank are liable for the money.[...] (b) Another aspect of the bank's charge is that traders should also be asked to pay charges other that the labor charges to the bank and a certain percentage out of the businessmen's share be made to be given to the bank which should be made partner of the business with certain percentage of the share". (Islamic Free Banking, 2011, p.48-49) 
depositante. Mudaraba é mais difícil ser executada nesta base. Por sua vez, nem juros ou compensação geralmente serão pagos nos depósitos móveis.

O banco pode, no entanto, diferenciar entre muitos tipos de depósitos. Parte dos depósitos móveis serão mantidos pelo banco para atender a liquidez necessária pela natureza dos depósitos e para reembolsar os depósitos solicitados. Outra parte será usada nas operações de mudaraba. Desta vez, no entanto o banco agirá como um empresário, e não um intermediário. Uma terceira parte será usada pelos bancos para ajudar a cobrir as necessidades, além de projetos da mudaraba de seus melhores clientes. Não relegando obviamente a mudaraba para segundo plano. Afinal, a importância de um banco livre de juros em um ambiente convencional é encorajar o clima no qual a mudaraba se torna uma norma e não uma exceção, na visão de Assadr.

No uso dos depósitos móveis, o banco dará atenção a um número de condições. $\mathrm{O}$ tomador de empréstimo deve ter uma boa reputação estabelecida e o banco deve ser capaz de avaliar a validade das operações empreendidas. Para isso, as garantias devem ser requeridas do tomador de empréstimo como uma segurança. $\mathrm{O}$ ressarcimento no empréstimo não deve exceder mais que três meses, isto irá garantir que operações de empréstimo a longo prazo terão uma forma normal para a mudaraba.

Na segunda parte da tese de Assadr, o autor discute várias transações financeiras da banca livre de juros permitidos sob as regras da lei islâmica. O conceito legal que constitui a base das transações realizadas pelo banco islâmico e o banco tradicional é diferente, mesmo que na prática possa indicar que o banco islâmico toma a mesma posição de depósitos sob demanda imediata. Os bancos islâmicos consideram estes depósitos como empréstimos dos depositantes para o banco, sem nenhum juro.

No banco tradicional, o depósito na conta corrente tem um desenvolvimento lento na opinião de Assadr, de um contrato de compensação que foi primeiramente decidido pelas cortes, então foi adotando cada vez mais a forma de uma transação autônoma. A conta corrente foi, portanto um contrato entre o banco e o depositante no qual os direitos pessoais perdem sua personalização ${ }^{198}$. Vagarosamente, estes direitos são perdidos no

198 "Bank deposits, are generally regarded as imperfect trust since the cash in not safe in its real from, and the bank is neither liable to return back the same cash on demand. Its only liability is to give back and amount of the same quantity in the currency of the time. The depositors have no right of putting any objection over it. In reality, the depositors (which are called amanhah in Arabic; this word otherwise means trust, entrusting something in good faith) cannot be regarded as amanah, neither imperfect nor perfect in terms of Islamic Jurisprudence. It is a sort of debt whose repayment from time to time (in parts) or at a certain time is binding. Thus the effects of 
desenvolvimento dos contratos e a ideia de compensação entre os direitos do banco como um substituto ao tomador de empréstimo, tomando um empréstimo do banco diminuem em proporção ao grau de autonomia atingido pelos contratos de contas correntes.

Outra teoria de destaque em sua pesquisa é a questão dos cheques. Há duas maneiras de explicar a teoria de Assadr sobre o cheque como uma operação legal, quando o sacador tem uma conta de crédito no banco. A primeira possibilidade é o conceito da istifa'. Em sua teoria, o cheque é considerado um contrato de letra de câmbio, do devedor para seu credor, retirado no banco onde o devedor (sacador) possui seus depósitos. Esta operação é considerada legal dentro da lei islâmica. Se por outro lado, a operação de cheque é considerada um novo empréstimo do banco, no qual o cheque é sacado, assim duas obrigações são criadas. As regras islâmicas de empréstimo aqui devem ser aplicadas. Não é possível sacar de contas bancárias se os cheques são considerados como empréstimos. Portanto, nestas ações é necessário que se analisem as leis islâmicas.

Estas duas teorias pressupõem que o sacador tem um crédito positivo com o banco. Na situação em que o sacador não tem fundos suficientes para cobrir o cheque haverá um problema, já a teoria esta baseada no conceito de empréstimo, quando as condições formais necessárias para o empréstimo devem estar presentes.

Na questão dos depósitos, o autor consegue descrever e lançar ideias sobre uma teoria interessante. Assadr procura descrever suas ideias sobre o depósito, do ponto de vista do relacionamento entre o banco, o depositante e o tomador de empréstimo. Aqui é dada ênfase à teoria legal dos depósitos, derivada da lei islâmica. Os depósitos nos bancos tradicionais operam na base de fundos a juros, que são inaceitáveis nos bancos islâmicos e devem ser convertidos em uma operação legal como a mudaraba nos bancos islâmicos.

Os depósitos na poupança são compreendidos como uma conta em um registro que deve ser produzido cada vez que um depósito e uma retirada são feitos. Como os depósitos fixos, eles devem operar com base na mudaraba. Há duas diferenças importantes nos regimes de depósitos em poupança num banco livre de juros. Primeiramente o poupador deve ter a permissão para a retirada dos depósitos quando

ownership of the respective owners get lost totally from the money so deposited and the bank gets full right to use it. An Amanah cannot afford this liberal use. It is a character of the debt only that an object of debt does into ownership (of debtor) only to give him right to use it at his will.[...] But with the passage of time and experience, change has been being occurred in the nature of these deposits. (Islamic Free Banking, 2011, p.94-95) 
deseja, ao passo que os depósitos fixos devem permanecer no banco por um período não menos do que seis meses. O banco islâmico deve reservar uma percentagem dos depósitos de poupança para serem considerados como empréstimo e manter como moeda fiduciária que não deverá ser utilizado pelo banco ${ }^{199}$.

Nos chamados depósitos reais, al-wada' $e$ ' al-haqiqiyya, os fundos que os depósitos mantêm com o banco para poupança, não se diferenciam de nenhuma forma de seu regime tradicional nos bancos convencionais. Uma taxa para manter o depósito real é válida.

Os depósitos são um meio de multiplicar os fundos, através da forte garantia derivada do elemento de confiança do banco. Então os meios de pagamento expandem os âmbitos comerciais e econômico ${ }^{200}$. Na visão do autor, depósitos representam verbas, que até serem mantidas pelos bancos, estavam economicamente inativas. Por entrar no mercado econômico, estes depósitos contribuem para a ativação da economia, indústria e para o crescimento do país.

Para Assadr, os depósitos contribuem para melhorar e ampliar o relacionamento fiduciário e criar uma capacidade de multiplicar os negócios e o autor trabalha diversos pontos destes tópicos dentro da lei islâmica. Como um meio de pagamento, através da emissão de cheques, depósitos tornam-se débitos para o banco. Um débito pode ser usado para compensar outro débito pela hawala e o cheque pode ser usado como um meio de pagamento. $\mathrm{O}$ débito pode ser usado como um meio de pagamento, como quando o credor compra no débito que ele tem com o devedor de alguma mercadoria, ou quando ele doa esse débito para outra pessoa ${ }^{201}$.

199 "Em caso de depósitos fixos o banco tem uma opção de forçar os depositantes não retirar seu dinheiro antes de seis meses da data do deposito. Porém, nestes depósitos, não existe tal opção para o banco. Há uma condição desde o começo que o depositante pode retirar seu dinheiro quando ele precisa e o banco não pode fazer objeção[...] A questão é o que pode ser feito se o depositante demanda o dinheiro após ser investido na mudariba. A solução pode ser que o banco pode decidir no inicio que o depositante pode ter o direito apenas a uma parte do seu dinheiro e o resto deve ficar com o banco." (Islamic Free Banking, 2011, p.73)

${ }^{200} \mathrm{O}$ autor lança mão de três argumentos para explicar em sua opinião a importância dos depósitos bancários, defendendo a ampliação da utilização destes (Islamic Free Banking, 2011, p.112-113) 201 "A second way of depositing is that the owner of money brings a check drawn in favor of him or the bank and requests the bank to get the check cashed and transfer and credit the amount to the account of the bearer of the check. It's like that there are two persons, one creditor and one debtor. The debtor wants to repay his loan and has issued a check for an amount equal to the loan amount in favor of the bank and gives it to his creditor. The creditor takes the check to bank and demands it to credit the amount equal to the amount of the check in his account. It means that the owner of the money has got the amount deposited in his account. There is only a difference that he has adopted check medium instead of cash. This way of depositing is also connected with 
Sob a lei islâmica, a última alternativa e que pode ser aceita, e de fato, o autor apresenta os contras em sua pesquisa e as duas condições são, primeiramente quando a mercadoria comprada não é uma commoditie futura. Nesse caso, débito pode ser comprado contra débito. Esta transação é proibida; segundo, se o credor doa seu débito a outra pessoa, o doador só pode doar a si mesmo, de outra forma a doação será considerada nula.

Concluindo, Assadr sugere excluir as complicações da segunda teoria e se ater apenas à primeira. Os cheques poderão ser vistos como um meio de pagamento usado como uma ferramenta de resgate. Sob esta teoria legal, são válidas sob a lei islâmica. $\mathrm{O}$ autor não vê problema com a segunda visão dos depósitos como uma forma de acumular capital para usos econômicos, porém a teoria tradicional só é aceitável se a utilização da verba é através do sistema de mudaraba. A teoria de criação por depósitos de extensão e circulação fiduciária no banco levanta questões legais, no sentido de que seria possível para o banco aumentar a circulação fiduciária e, portanto, ter um endividamento maior do que o montante de depósitos em sua possessão $0^{202}$. O autor discute diversas hipóteses que estariam dentro da lei islâmica ${ }^{203}$ e estas ilustram a capacidade do banco de capitalizar os

withdrawal of the money from the account of one issuing check. It is of course, its offshoot, so it can be discussed when discussing about the problem of the check cashing as per Islamic laws and decoding Islamic jurisprudential position of money withdrawal though the method shall be proved as correct with no objection under Islamic law." (Islamic Free Banking, 2011, p.101)

202 "Is $i$ salso a permissible formo of depositing the amount that is not objectionable according to Islamic laws.Besides these means, there is other types of recording in which the amount is credit to the account of the account holder whogets no information about it unless and until the bank statement or specific information is not delivered to him. It is usually done when some draft in favor of the accounts holder comes to the bank from abroad or from within the country. It might be some businedd money or some other amount. The bank debits the amunt from the account of drawer of the draft and credit it to account of the account holder (in whose favour the draft is issued), thus the amount (balance) the account holder increases automatically." (Islamic Free Banking, 2011, p.102)

203 "Primeiro caso: o presente depósito com o banco é de mil rupias. Duas pessoas acessam o banco pedindo um empréstimo de mil rupias cada um. Agora o banco sabe que ambos os devedores poderiam depositar seus débitos apenas com o banco e não irá pedir para retirar ao mesmo tempo. É fácil para o banco se favorecer de ambos e se tornar credor de dois mil. Segundo caso: o presente montante de depósitos com o banco de mil rupias. Uma pessoa chega e pede um empréstimo de mil rupias o qual o banco dá. Depois de conseguir o montante, ele dá a seu credor que deposita o montante novamente no mesmo banco. Depois de algum tempo, outra pessoa vem e pede um empréstimo de mil rupias. $\mathrm{O}$ banco empresta o mesmo montante o qual ele já tem. Então, o capital atual do banco é de mil rupias, porém seu montante de crédito é de duas mil rupias. Terceiro caso: $\mathrm{O}$ deposito com o banco é de mil rupias e o banco transfere para duas pessoas que não possui conta com o banco, porém o banco especula que não terá que enfrentar a posição embaraçosa de pagar no mesmo tempo. Sob as circunstâncias de aceitar ambas as 
depósitos.

O problema na teoria legal reside que o banco meramente promete entregar 1.000 rupias para cada respectivo tomador de empréstimo, quando o banco de fato não possui o dinheiro em seus cofres. Este compromisso, ou promessa de empréstimo, não é aceito sob a lei islâmica, porque o "elemento da comprovação", que é necessário na lei islâmica para o empréstimo, é inexistente nesta operação.

Apesar de Assadr, em sua pesquisa, devotar uma longa seção para discutir um grande número de transações financeiras que são tradicionalmente executadas no sistema bancário, estas transações são discutidas por Assadr visando os preceitos da lei islâmica. Neste período, também não era tão desenvolvido o sistema financeiro como na atualidade, mas é perceptível que seu trabalho forneceu a base para o sistema que temos hoje.

Sobre os cheques, Assadr já havia abordado sua visão legal como uma transação entre duas partes através do banco. O autor ofereceu duas justificações jurídicas em seu texto (a teoria de istifa' e a teoria da combinação de empréstimo) e sugeriu que a primeira teoria era mais simples e fácil para ser utilizada pelos bancos. Outro ponto importante que Assadr irá discutir é a importância e a validade de se cobrar uma taxa no processo de pagamento do cheque.

O autor parece preocupado que na prática, o banco não irá geralmente cobrar uma taxa sobre a emissão de cheques do cliente, exceto em casos onde se envolve uma transação ou serviços internacionais ${ }^{204}$. Assadr examina dois argumentos legais na operação e defende que é apenas uma questão de uma única ou dupla transferência, ou transferência combinada com uma venda. A transação será uma transferência única se cheque é sacado no mesmo lugar e pelo mesmo banco onde foi coletado pelo beneficiário - sacador ou é uma dupla transferência se um banco diferente está envolvido. Neste caso, existe uma transferência do sacador do cheque no banco onde o cheque é sacado, porém

transferências significa duas pessoas tem se tornado devedores do banco por mil rupias cada, porém o dono do dinheiro do banco não excede mil rupias".

204 "A person exporting something abroad eyes apparently some guarantee from the importer so that it could be exported on its credit. But sometimes exporter, instead of demanding personnel surety from importer, takes his promise to pay as and when the documents of the thing (to be imported) reaches. The exporter submits these documents to the bank mutually agreed on between him and the importer. The bank sends the documents to another bank in the city so as to deliver them to the importer after taking payment from him. After taking the amount, the bank's duty is to intimate to the other bank to the effect that the amount has been received and recorded in its current account.It is obviously a permissible service that the bank undertakes for business facilities and its purpose is to take payment from there credit's bank has become indebted to the exporter through the account." (Islamic Free banking, 2011, p.125) 
o coletor do cheque negocia com um banco diferente, que credita o montante do cheque em sua conta com o primeiro banco. Isso significa que o primeiro banco tem passado o cheque do sacador para o segundo banco.

O cheque pode também ser concebido como uma operação combinada de transferência e venda ${ }^{205}$. O sacador endossa o cheque para beneficio do sacado através do banco, e o sacador torna-se do dono do valor do cheque. Então a transação de venda é operacionalizada quando o sacador-dono vende a parte que possui com o banco, isso será uma venda de débito.

Se a primeira ou a segunda justificação é adotada, a operação de cheque é valida pela lei islâmica. No entanto, em termos de coleta de taxa quando se saca o cheque, é aceito somente se o cheque é sacado em outro banco que não o banco de liquidação ou se o banco emissor não possui conta para credor-sacador. Se o banco possui uma conta para o sacador, o banco pode cobrar uma taxa somente se um acordo prévio com seu credor ${ }^{206}$. A distinção aqui esta enraizada no fato de que a operação neste último caso será transferir a propriedade do débito somente com aceitação formal do devedor substituto, o banco ${ }^{207}$.

Se o banco tem filiais entre diferentes locais no mesmo país, pode pedir uma taxa por sacar o cheque num local que não onde foi realizado o depósito.

O autor procura discutir outras atividades realizadas pelo banco, tais como transferências, especialmente quando envolve grandes distâncias e considera a imposição de taxas nessas operações para serem legais. O banco também pode cobrar taxas quando

205 "As explained while discussing the current account, it is also a way of deposit in the bank, that an account holder gets a cheque drawn in his favour by some party of the bank and deposits it in the bank, which then credits the amount to the account of the payee of the cheque." (Islamic Free banking, 2011, p.120)

206 "The cheque is sometimes drawn on the same bank or even on the same branch, where it is submitted for cashing. Sometimes, it is on some other branch and sometimes it is on some other bank even. In the first case cashing the cheque is a only. The drawer of the cheque has referred his creditor to the bank where he already holds an account. In the second case, there is just a transfer as the bank with all its branches are as if those of the main unit." (Islamic Free Banking, 2011, p.120-121)

207 "When a cheque is drawn on Lucknow branch, it does not mean that only that branch is liable but in fact bank as a whole is liable to pay the amount in cash. Despite it, the main bank is not liable to cash the cheque from every branch but is has its discretionto cash at the very branch on which it is drawn. Nobody can have a right to object to it. It the payee of the cheque wants to cash the cheque drawnon Luckow brach from Delhi branch of the same bank, the branch has every right to charge for service. The charge for the service is not permissible when some liability is established on someone and he fulfills his obligation. But when there is no liability on someone or on some entitle, fulfilling other's liability can be charged." (Islamic Free Banking, 2011, p.124) 
subscreve novas companhias, emitindo ações, letras de câmbio, garantias de crédito, documentos etc. Todas estas atividades são geralmente considerada legais, e pode haver pouca dissimilaridade na forma ser performance dos bancos tradicionais e dos bancos islâmicos.

Existe, no entanto, a discussão sobre a cobrança de taxas. Assadr insistirá na questão de se não impor taxas no banco islâmico, a menos que o banco possa justificar a taxa de uma forma legal, um serviço especifico realizado pelo banco. Este está encarregado de cobrar uma taxa para beneficio de seus clientes se a cobrança ocorre por receber o dinheiro em caixa ou por transferir o valor da ordem de pagamento da conta do credor para a conta do beneficiário.

Na categoria em que aborda a questão dos empréstimos e facilidades, Assadr discute três pontos importantes: os empréstimos propriamente, os papéis comerciais relacionado às operações de desconto e as cartas de crédito.

Uma diferença significante entre o sistema convencional e a banca islâmica, pelo menos na teoria legal destas atividades é o regime de câmbio descrito por Assadr. As regras de cobrança na lei islâmica mudam de acordo com a natureza da moeda utilizada ${ }^{208}$, contando que a moeda envolvida é o papel moeda, a base no qual este papel moeda é criada determina a maneira que a lei irá organizar as operações com esta moeda. No caso de ouro e prata, o autor argumenta que os juristas clássicos têm permitido a transação dentro de duas condições. A equivalência em quantidade entre o preço e a commoditie, quando ambos são feitos de ouro ou prata e a execução completa a execução da transação no local do contrato.

Assadr aqui discute a questão, defendendo o argumento de que, de fato, a única condição necessária na transação deve envolver ouro e prata. Equivalência é necessária, mas a troca pode não ser instantânea, executada imediatamente. $\mathrm{O}$ autor argumenta que sobre isso só há um hadit, não necessitando assim de mais condições.

Sobre a compra e venda de moeda estrangeira, deve ser permitido para o banco e

208 "If the price is to be paid in the currency of exporter as agreed upon, the buyer's duty is to deliver in the currency of the seller's country to his country after getting them in the required quantity from the market and clear his debt off. It was the territory ruled by the currency traders (money-changes) who were controlling prices. Until the banks entered into arena and have introduced significant means replacing the cash payment by designing it. Now cheques and transfer have replaced the cash payment. With the development if the business, it has been easy for a bank to dominate over whole business by replacing the currency changers and it has started the work also." (Islamic Free Banking, 2011 p.152) 
o lucro também é valido para esta transação. Similarmente, um mercador pode pedir por uma taxa, para garantir que o preço de uma mercadoria em moeda estrangeira não aumente em caso de desvalorização, e seu pagamento presente na moeda local seja adequado para o tempo da entrega da mercadoria.

\subsubsection{Bancos no Ambiente Islâmico}

Tanto no livro Iqtsaduna quanto em sua pesquisa para a banca livre de juros, há uma insistência no papel do Estado na economia, assim como a necessidade de estabelecer a justiça social. As regras islâmicas como a riba foram partes de um modelo de estado intervencionista. Em 1969, esse sistema foi proposto e a banca islâmica introduziu uma ordem islâmica dentro do ambiente capitalista. Dez anos depois, quando a revolução islâmica ocorre no Irã, um modelo islâmico surge, dentro de um ambiente capitalista e secular. A pesquisa de Assadr é um esquema que de certa forma tem certo sucesso dentro da revolução islâmica.

Sob o capitalismo, o banco possui dois papeis, um papel objetivo, que é a mobilização dos fundos para a indústria e o comércio, e o papel subjetivo, que é a concentração do capital nas mãos de poucos que controlam a economia e irão usar esse capital para reproduzir e reforçar o sistema. $\mathrm{O}$ banco em um sistema islâmico divide com o capitalismo o objetivo da mobilização dos fundos, porém é evidente que o papel subjetivo é completamente diferente.

O contraste essencial entre os dois modelos é baseado na primazia do trabalho na criação de riqueza no sistema islâmico e o papel do risco. No capitalismo, o banco permite aos capitalistas ganhos fixos que estão separados da questão do trabalho e do risco. Já no sistema islâmico, ambos os conceitos são centrais no sistema financeiro.

Aqui é onde o papel do Estado, através da sua responsabilidade na busca a justiça social, deve ajudar os pobres e oprimidos, prevenindo a acumulação de capital nas mãos de poucos. No Islã, estes são assuntos temas de políticas públicas que estão em consonância com o papel do banco como regulador da distribuição de riqueza.

De fato, o banco islâmico terá duas formas: receberá os depósitos, e a primeira forma do uso dos fundos depositados será uma garantia de empréstimo para o depositante, que se torna credor do banco com direitos limitados. O depositante será capaz de sacar seu depósito quando desejar. O depositante ainda pode destinar seu depósito a projetos 
filantrópicos específicos no auxílio dos pobres. Assadr aqui destaca a questão de que a pessoa será capaz de manter o real valor do depósito, protegendo da inflação. A segunda forma de banco é a mudaraba, no qual os lucros são divididos entre o banco e o depositante, que atua como um intermediário na operação, sendo que o banco cobrará somente uma taxa de intermediação.

Esse modelo se apresenta agora como uma alternativa ao modelo capitalista e, de certa forma, incorpora a economia de mercado com uma mão forte do estado islâmico, com grande interferência no sistema bancário, sendo que o foco destes bancos deve ser o social. Obviamente esses bancos têm encontrado formas de lucratividade e tem desenvolvido sistemas no mínimo interessantes de se aprofundar.

$\mathrm{O}$ cenário internacional do século $\mathrm{XX}$ foi propício ao aparecimento da Banca Islâmica, a economia global com o fracasso de suas ideologias acabam por abrir espaço para ideias alternativas. Nos anos oitenta, um período de desintegração da União Soviética e o forte desejo de se adentrar no cenário internacional sem se ligar ao capitalismo, ocorre que os muçulmanos defensores de um movimento de volta do Islã no domínio do sistema, acabam conseguindo transformar o sistema capitalista que adentrava no Oriente Médio e Ásia.

Os bancos islâmicos possuem muitos desafios para penetrar no mercado internacional bancário, porém, a ideia de um sistema livre de juros agrada certamente a população pertencente às três grandes religiões monoteístas. 


\section{Operações Bancárias no Islã}

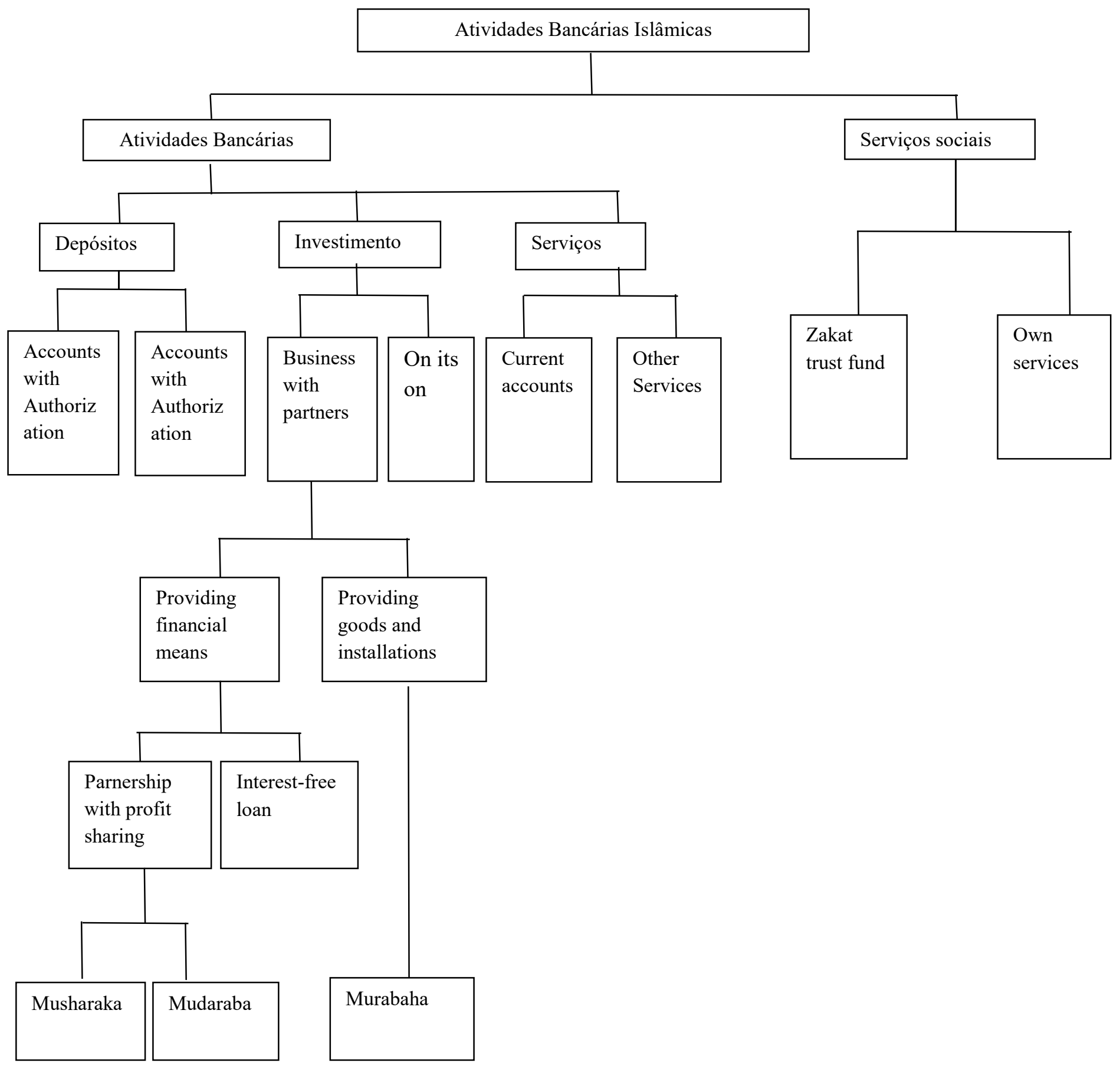

Figura 1- As operações bancárias (EL-ASHKER, Ahmed. WILSON, Rodney. Islamic

Economics: A Short History. Boston: Brill, 2006 p.347) 


\subsection{As Críticas de Assadr ao Marxismo e ao Capitalismo}

\subsubsection{Componentes Básicos da Doutrina Marxista}

Em sua crítica, o autor argumenta que há dois aspectos na economia, o aspecto científico e o aspecto doutrinário, sendo que a ciência econômica é ciência, o que dá a explicação da vida econômica, seus eventos e fenômenos econômicos, e a ligação desses eventos e fenômenos com as causas gerais e os fatores que nela governam. A doutrina econômica, para o autor, é uma expressão da maneira como uma sociedade prefere seguir em sua vida econômica, como forma de solução de seus problemas práticos ${ }^{209}$.

A linha de demarcação entre a ciência e a doutrina é a ideologia de justiça social, na opinião de Assadr, e ainda advoga que se deve buscar o equilíbrio de ideias e conceitos relacionados à sua ideia de justiça.

Para sua análise, o autor irá fazer uma divisão, na qual ele classifica a economia marxista como materialismo histórico (ciência marxista) e o socialismo e comunismo

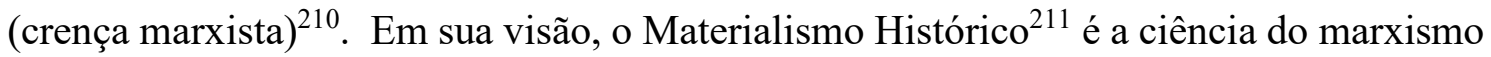
que dá a explicação econômica da toda a história à luz da força produtiva.

Para o autor, se o materialismo histórico não cumprir a sua função científica e, em

\footnotetext{
209 "A ciência econômica é: a ciência que trata da exposição da vida econômica, seus eventos, sinais externos e a conexão de ambos com as razões e fatores gerais que os controlam. Esta ciência surgiu recentemente, de fato, para tomarmos o sentido exato da palavra, ela apenas entrou em uso no início da era capitalista, por volta de quatro séculos atrás, muito embora suas raízes estejam nos tempos antigos. Toda civilização participou do pensamento econômico tanto quanto possível. Contudo, a primeira inferência científica exata na história da economia é reconhecida em séculos recentes. A doutrina econômica da sociedade é uma expressão do rumo que esta prefere seguir em sua vida econômica na resolução de seus problemas práticos. Com base nisso, não nos é possível imaginar uma sociedade sem uma doutrina econômica, pois toda sociedade que pratica a produção e distribuição da riqueza há de ter um método, o qual estuda de acordo com a organização das atividades econômicas, e é este método que determina sua posição doutrinária com respeito à vida econômica". (ASSADR, 2012, p.20)

210 “[...] começaremos nossa pesquisa sobre o marxismo com o materialismo histórico, em seguida nos dedicaremos à doutrina do marxismo, que se apoia nele; em outras palavras, estudaremos primeiramente, a teoria econômica marxista e a teoria marxista da história, e em seguida, a doutrina econômica do marxismo". (ASSADR, 2012, p.48)

211 "O materialismo histórico é uma metodologia especifica de interpretação da história. Em sua interpretação tende a (aceitar) um fator único. Essa tendência no materialismo histórico não é exclusiva, pois há um grande número de escritores e pensadores que estão inclinados à interpretação da história como a chave mágica que abre os segredos e desempenha o papel principal no processo histórico. Eles interpretam as demais influências como sendo secundárias, e seguem o que consideram o principal fator em sua existência, desenvolvimentos, transformações e sequências". (ASSADR, 2012, p.49)
} 
sua análise, for provado que não explica as leis das sociedades humanas, toda estrutura do credo marxista entrará em colapso, já que a fundação do credo marxista repousa sobre o materialismo histórico.

\subsubsection{O Materialismo Histórico como Fator Único}

Segundo Assadr, o Materialismo Histórico é a interpretação da história em termos de fator único, de acordo com a teoria a formação econômica que determina as manifestações sociais, políticas, religiosas, e ideológicas. Quanto à formação econômica $^{212}$, tem sua causa nas forças $\operatorname{produtivas~}^{213}$ e nos meios de produção ${ }^{214}$.

Para o autor, não há um fator único que move a história da humanidade. Não se pode, segundo sua crença, ter um fator único como economia, raça, geografia, para se interpretar o movimento da história.

Há certo incômodo por parte de Assadr sobre a questão do conflito entre forças de produção de propriedade e o conflito de classes. Também buscará debater que os fênomenos históricos, sendo parte de uma totalidade dos fênomenos naturais, estão sujeitos às leis que governam o universo inteiro. A lei da causalidade seria uma destas que, segundo o autor, qualquer discurso da história que não admita a aplicação desse princípio da lei da causalidade em seu campo seria sem sentido.

Assadr afirma que, para cada ocorrência social e histórica, muitos fatores, incluindo social, política, econômica, cultural e psicológica, também estão operando. Portanto, a interpretação da história em termos de fator único não pode resistir ao teste da

212 “[...] o marxismo crê que é a formação econômica que determina a estrutura social, política, religiosa, ideológica e as demais manifestações da existência social. Quanto à formação econômica, também, que há uma causa como há para todas as coisas materiais e que a principal coisa da mudança social coletiva e subsequentemente para todos os movimentos históricos na vida humana é modo (que se apresentam) as forças produtivas e os meios de produção". (ASSADR, 2012, p.50)

213 "As forças produtivas geraram o movimento histórico de acordo com as mudanças e com o que surgia com as mesmas; e explica isto dizendo que as forças produtivas continuam se desenvolvendo e se ampliando constantemente como temos visto. E que para cada estágio definido de desenvolvimento dessas forças produtivas e meios de produção, e os produtos que dependem de ferramentas simples de pedra se diferenciam dos que dependem do arco e flecha e de outras armas semelhantes de caça; e os produtos de caça se diferenciam daqueles do pastor, do rebanho ou do agricultor". (ASSADR, 2012, p.51)

214 "Os meios de produção são as ferramentas que o homem emprega para a produção daquilo que necessita, pois o homem está obrigado a lutar com a natureza para sua existência e esta luta exige força psíquica e determinados tipo de instrumentos que o homem emprega no manejo da natureza para fazê-la produtiva para o seu benefício". (ASSADR, 2012, p.51) 
razão e da ciência em sua visão.

\subsubsection{O Materialismo Histórico à Luz da Filosofia}

Para o autor, o marxismo considera necessários os meios de produção para interpretar a história e, de acordo com isso, o materialismo é necessário para se interpretar a existência do homem em geral. Já a história é apenas uma parte desta existência ${ }^{215}$.

Assadr não concorda com o marxismo. Argumenta que o materialismo, na sua concepção filosófica, significa que a matéria, com suas múltiplas manifestações, é a única realidade que inclui todos os fenômenos da natureza dentro dela. Uma visão tão filosófica não faz diferença se o homem é considerado como sendo o produto das condições materiais e as forças de produção ou as condições de produção e suas forças são o produto do homem. Em outras palavras, o materialismo histórico e o materialismo filosófico são duas teorias independentes. O autor também não concorda com o marxismo na aplicação de método dialético ${ }^{216}$ na investigação da história. Assadr observa que os resultados a que se chega são contrários à lei da dialética ${ }^{217}$.

Segundo Assadr, o marxismo é de opinião, com base na lei da dialética, que a contradição de classe é a única causa principal dos conflitos internos na sociedade e todas as outras contradições apenas surgem a partir dela. Mas, ao mesmo tempo, estabelece que

215 "A filosofia do materialismo marxista crê que a característica distintiva da nova filosofia do materialismo é a sua interpretação material da história, uma vez que sem isso não é possível dar uma correta interpretação da história que se conforme inteiramente à filosofia do materialismo e que coincida com a concepção material da vida em todos seus procedimentos. Desde que a interpretação material é verdadeira - na opinião do marxismo - no caso da existência em geral, será verdade no caso da história também) já que a história é apenas uma parte da existência." (ASSADR, 2012, p.57)

216 "Leis da dialética são as leis que interpretam todo o desenvolvimento e que o convenciona em termos de conflito entre os opostos no conteúdo interno das coisas, pois tudo carrega dentro de si um germe oposto que se empenha na luta com seu contrário e desenvolve-se em conformidade com as condições da contenda". (ASSADR, 2012, p.60)

217 " [...] em sua capacidade dialética afirmou que crescimento e desenvolvimento surgem de contradições internas e que a contradição interna é suficiente para explicar todo o fenômeno natural sem a necessidade de qualquer outra força ou causa externa, enquanto que por outro lado reconheceu as relações de causa e seu interior. Essa vacilação também se reflete em sua análise histórica, pois, quando insiste sobre a existência de contradições enraizadas no âmago de todo fenômeno social como suficiente para seu surgimento e movimento e, por outro lado, reconhece que o imenso edifício social, em sua integridade e modo particular, se encontra sobre uma fundação, e que as forças produtivas, as formas ideais, econômicas, políticas, etc. são apenas superestruturas deste edifício e reflexos em outra forma do modo de produção sobre o qual este está erigido". (ASSADR, 2012, p.61) 
a "caravana da humanidade" esteja viajando inevitavelmente em direção a uma única classe. $\mathrm{O}$ autor pergunta, como pode explicar o marxismo o movimento dialético em uma sociedade de classes, desde que a contradição de classe tenha encontrado seu fim inevitável ${ }^{218}$ e desde que o movimento dialético não pode surgir, exceto com base em contradição?

Assadr observa que existem três tipos de argumentos apresentados pelo marxismo em favor do materialismo histórico. Estes incluem argumento filosófico, argumento psicológico e argumento científico.

Segundo o autor, o argumento filosófico é baseado no princípio de causa e efeito. Neste princípio, nada ocorre por acaso e que, para cada ocorrência há uma causa. Para o autor o marxismo é de opinião que as idéias e opiniões não podem ser consideradas como a causa básica por trás dos acontecimentos históricos e sociais porque essas idéias também estão sujeitas a causas particulares e da sua vinda à existência. Portanto, é necessário interpretar a história em termos de meios de producão. Por isso o marxismo critica a filosofia idealista. Assadr (p.72) cita Plekhanov:

\begin{abstract}
"Hegel viu-se caído no mesmo círculo vicioso em que os sociólogos e historiadores franceses haviam caído, pois explicavam as formas sociais pela condição existente das ideias; a condição existente das ideias pelas formas sociais...e o problema permanece sem solução até que a ciência se liberta desse círculo vicioso "b" sendo causa de "a" que ao mesmo tempo especifique "a" como causa de "b".(A Filosofia da História)
\end{abstract}

De acordo com Assadr, o marxismo explica a história das forças de produção e sua evolução em termos de meios de produção. Sua teoria argumenta que as forças de produção são as forças que mudam a sociedade e, posteriormente, a sociedade muda o

\footnotetext{
218 “[...] a contradição de classes que reflete as contradições dos meios de produção e as relações de propriedade é a única e essencial causa dos conflitos internos na sociedade e que todas as outras contradições apenas derivam dela, ao mesmo tempo estabelece que a "caravana da humanidade" viaja inevitavelmente na estrada da obliteração das classes sócias para sempre e que isto ocorrerá quando os sinos da vitória soarão para o proletariado e a sociedade sem classes terá nascido e a humanidade adentrará o estágio do socialismo e do comunismo. Quando as classes e as suas contradições tiverem desaparecido da sociedade, então naquele estágio a maré do processo revolucionário terá chegado ao fim, a chama do eterno e dinâmico movimento terá sido extinta e o milagre que retirará o encargo das leis dialéticas terá ocorrido. Ou, então de que outra maneira o marxismo explica o movimento na sociedade sem classes, já que as contradições classistas encontraram seu inevitável fim e desde que o movimento dialético não pode surgir exceto com base na contradição?’(ASSADR, 2012, p.65)
} 
todo para entrar em conformidade ${ }^{219}$. Isso pode explicar por que as forças de produção, no curso da interação do homem com a natureza, dão à mente do homem ideias reflexivas e conhecimento. Através destas idéias e conhecimento, o homem faz invenções de novos meios de produção e assim o desenvolvimento e renovações das forças produtivas acontecem.

O desenvolvimento das forças de produção é realizado em correspondência com o desenvolvimento reflexivo e científico e o desenvolvimento reflexivo e científico é formado por essas forças de produção durante o decurso da sua experimentação. Deste modo, afirma Assadr, segue um curso circular na explicação das forças de produção e desenvolvimento científico.

O autor argumenta que se tal curso circular é possivel do lado filosófico, então também é possivel dizer que a formação social resulta de experimentos sociais que os homens conduzem durante o curso de sua interação com outros indivíduos. Isso ocorre da mesma forma como o homem realizou experimentos com a natureza das forças produtivas, durante o curso de suas operações produtivas.

As ideias práticas da sociedade desenvolvidas sob o abrigo desses experimentos sociais, assim como a mente do homem que se desenvolveu durante o curso de sua experimentação com a natureza, são o resultado de experiências sociais que dão origem a novas experiências, consequentemente, levam ao desenvolvimento da totalidade da sociedade. Desta forma, Assadr fornece a possibilidade de uma explicação alternativa da história $^{220}$ : o autor se refere à justificação dessa possibilidade pela lei de causa e efeito

219 “Assim sendo, a interpretação da história não pode livrar-se do círculo vicioso no campo da investigação, a menos que aponte os meios de produção como a causa principal. Isso é o que é denominado de argumento fílosófico e foi nosso vivo desejo apresenta-lo da melhor maneira possível.[...] Com o intuito de preparar o caminho para a resposta à questão adotamos um ponto ligado aos meios de produção que o marxismo diz ser a verdadeira causa da história e esse ponto é que: os meios não são inertes ou estáticos, mas por seu turno também mudam e se desenvolvem com a passagem do tempo,da mesma maneira que as ideias e pontos de vista do homem como também as formas da sociedade mudam com o tempo. Consequentemente, um meio de produção morre e outro nasce. Assim podemos perguntar sobre a causa mais profunda que produz o desenvolvimento dos meios de produção e que se mantém fora da visão, oculta ao curso da história; como também perguntamos sobre os fatores e causas que seguem na direção da criação das ideias e das formas sociais".(ASSADR, 2012, p.73)

220 "Com tal base não há nada que impeça que o marxismo explique a formação social por intermédio dos pontos de vista práticos e que em seguida explique as mudanças e o desenvolvimento dos mesmos por meio da experiência social, como exemplificado nas formações econômicas, políticas etc... visto que tal explicação alternativa se assemelha inteiramente à explicação marxista de que cada fase histórica da força de produção e da mente científica se torna igual à outra fase pouco a pouco". (ASSADR, 2012, p.76) 
em que o marxismo acredita.

De acordo com Assadr, o argumento psicológico proposto pelo marxismo e a ascensão do pensamento na vida da humanidade resultam de fenômenos e formas de uma sociedade específica. Pensamentos aparecem na história como um resultado de fenômenos sociais na vida da humanidade. Isso significa que os fenômenos sociais são anteriores ao pensamento. Consequentemente, não é possível explicar qualquer fenômeno social na sua primeira formação por fatores ideais. Em apoio a este argumento, o marxismo tem a ajuda da linguagem ${ }^{221}$.

Em outras palavras, pensamentos não podem surgir sem linguagem e a linguagem é nada além de um fenômeno social. $\mathrm{O}$ autor ainda contesta este argumento e afirma que o pensamento tem sua existência independente de comunicar suas idéias aos outros. Para o autor, o homem é um ser pensante, sem linguagem. Não é a linguagem que, ao entrar em sua vida, fez dele um ser pensante ${ }^{222}$.

Assadr procura destacar sua visão de que a linguagem aparece na vida do homem e não em outros seres, porque só o homem é capaz de pensar e refletir e só é possível para ele perceber e mudar a realidade existente ${ }^{223}$. Se a linguagem é assumida como sendo o resultado de forças produtivas, então essa linguagem deveria passar por uma mudança com a mudança nas forças produtivas ${ }^{224}$.

221 "Isso torna evidente a ênfase marxista no fato de que os pensamentos nasceram com a linguagem e a linguagem nada mais é do que um fenômeno social. Stalin diz: "Diz-se que as ideias vêm à mente dos homens antes deles se expressarem com a fala e que as ideias são originadas sem o meio da linguagem, isto é, sem a estrutura da linguagem ou em outras palavras elas estão estocadas na mente. Porém isso é um completo equívoco. Quaisquer que sejam os pensamentos, passam a existir somente com base no meio de linguagem, ou seja, com base nas palavras e sentenças linguísticas, e não existem pensamentos isentos de palavras ou livres de meios de linguagem ou de seu revestimento material natural que é a linguagem, pois a linguagem é a realidade direta da ideia, assim não é possível falar uma ideia sem a linguagem para ninguém exceto para os idealistas". (ASSADR, 2012, p.77)

222 "Assim, Stalin correlaciona palavras a pensamentos por consequência de que não é possível expressar um pensamento sem os meios de linguagem". (ASSADR, 2012, p.77)

223 "Foi porque o homem se tornou capaz de pensar, refletir, que foi possível que ele, e ele somente, transcendesse os limites da percepção e mudasse a realidade existente que apreende, e consequentemente alterasse as próprias percepções, em correspondência com a realidade tangível. Isto não foi possível para nenhum outro animal possuindo a faculdade do pensamento, posto que não é capaz de compreender nada ou pensar sobre nada, exceto a realidade tangível em suas formas específicas., de modo que não é possível para ele alterar a realidade existente para uma outra coisa.

224 "Portanto, é o pensamento que reserva ao homem o poder de mudar a realidade tangível num modo possível. E desde que a operação de mudança da realidade existente exige em várias ocasiões uma numerosa e variada sorte de esforços, a efetuação disto assume a marca coletiva, vários indivíduos se unindo neste empenho de acordo com a natureza do mesmo e de acordo com 
Para Assadr, a linguagem mantém o seu próprio ritmo de desenvolvimento e mudança que está nos pensamentos e necessidades dos seres humanos em vez de nas forças produtivas. Desta forma, o autor refuta o argumento psicológico do marxismo, segundo o qual, o pensamento não pode ser a causa de qualquer fenômeno social.

Voltando-se para a questão da argumentação científica, Assadr vê no marxismo uma explicação dos fenômenos históricos e sociais em termos de materialismo dialético, mas parece não considerar isso como uma explicação científica da história ${ }^{225 .}$

$\mathrm{O}$ autor argumenta que qualquer explicação hipotética atinge o grau científico somente quando a evidência científica é capaz de estabelecê-la como a única explicação possível dos fenômenos e negar as possibilidades de outras explicações. E, para Assadr, tal explicação é possível no campo das ciências físicas e não no das ciências sociais ${ }^{226}$.

Para o autor, quando "um investigador da história obtém a totalidade dos fenômenos e das ocorrências históricas, ele não possui diante dele a direção das possibilidades que o investigador dos fenômenos físicos possui”. O autor aborda as possibilidades que estão diante dele a respeito do átomo, seu núcleo, suas cargas elétricas, seus raios, Assadr acredita que o físico pode submeter o material em que está trabalhando a vários experimentos, tirando ou acondicionando a ele qualquer coisa do jeito que desejar (ASSADR, 2012, p. 86).

Assadr conclui que não é possivel aceitar o fator econômico como uma causa inevitável por trás de todos os eventos históricos e sociais como outros fatores, como social, religioso, politico e ideológico. Fatores psicológicos, ateístas, também possuem a

a extensão dos esforços requeridos para sua efetuação. Assim, a relação social se verificou entre os homens. Não é possível encontrar a existência de relações dessa natureza entre os animais de outras espécies visto que outros animais não são seres pensantes, não são capazes de realizar operações para criar mudanças positivas na realidade tangível, e assim, consequentemente, não surgem entre eles relações coisas dessa natureza". (ASSADR, 2012, p.82)

225 “[...] é o caso da explicação marxista da história (o materialismo histórico, o fato de não podermos considerá-la uma explicação adequada da história emerge de sua condição de história e de atingir o grau de teoria cientifica ou o grau certeza científica e confiabilidade, pela obtenção de evidência científica que repudie todas as demais hipóteses. Tomemos, por meio da ilustração, a explicação do materialismo histórico a respeito do estado. [...] Essa explicação marxista do estado ou do governo não pode adquirir valor científico seguro exceto se houver alguém que possa fazer ruir todas as outras explicações, pelas quais seja possível demonstrar o surgimento do estado na sociedade humana de modo diferente ao de um órgão político de exploração de uma classe. Mas se formos capazes de explicar esse fenômeno social sobre outro base, e a prova científica não puder rejeitar tal explicação, então, a explicação marxista não poderá ser considerada mais do que uma hipótese". (ASSADR, 2012, p.83)

226 “A matéria de análise da investigação no campo da história (a origem, o desenvolvimento da sociedade e os fatores operacionais básicos nela). 
habilidade de se tornar a causa destes eventos.

\subsubsection{Desenvolvimento de Forças Produtivas e o Marxismo}

O marxismo responde que são os pensamentos que o homem dispõe no curso de sua experiência com a natureza e que emanam de tais experiências que a seu turno desenvolvem as forças produtivas e participam de seu crescimento ${ }^{227}$. Assim a relação entre as forças de natureza produtiva que o homem experimenta e suas idéias e opiniões a respeito do mundo e dos fatos, se torna uma relação de causa com seu efeito que emerge dela, em seguida interage com ela e aumenta em riqueza e substância.

Assadr não tece grandes críticas neste ponto. De fato, sua visão parece estar sempre voltada ao centro de que o homem é a questão do problema econômico e não se preocupa demasiadamente a respeito das forças produtivas. Dos outros autores do período contemporâneo também não teremos aprofundamento neste aspectos das forças produtivas. Suas críticas procuram se ater mais à questão ideológica do que à compreensão do funcionamento do capitalismo.

\subsubsection{Ideologia e Marxismo}

O autor levanta que, para o marxismo, a causa real de todo processo ideológico está na religião, filosofia ou ciência que é latente na condição material e econômica ${ }^{228}$. A ideologia, se baseada na religião, filosofia ou ciência não tem história independente de si própria, muda apenas de acordo com as forças produtivas. Para Shariati (1980, p.49), a arma mais efetiva de negar o ocidente seria o marxismo. Colocando como "irmãos", tanto o protestantismo, o fascismo, o marxismo e o capitalismo, o autor consegue ligá-los,

\footnotetext{
${ }^{227}$ Os marxistas acreditam que o progresso a respeito do efeito de intercâmbio das forças produtivas e das ideias que emergem durante o esforço com a natureza no molde dialético expressa o movimento dialético do desenvolvimento das forças produtivas que como tais fazem nascer as ideias, em seguida tornam a crescer e desenvolver sob influência delas.

228 “[...] a formação da força produtiva, que determina o conteúdo total do caráter histórico do homem, como um dos pontos de maior relevância e importância na concepção material da história de acordo com o marxismo, pois a ideologia, em quaisquer das formas mais elevadas que possa ter assumido, por mais distante que tenha se afastado da força básica ou qualquer que seja o curso que possa ter escolhido dentre as complexas tendências históricas, apareceria numa análise como sendo o resultado do fator econômico em uma ou outra forma. Baseado nisso é que o marxismo explica por meio da condição material a história da ideologia, das revoltas e mudanças provocadas por ela". (ASSADR, 2012, p.103)
} 
argumentando que o protestantismo traz uma moralidade compatível com a vida burguesa e o capitalismo, para o autor, satisfaz esse desejo. Já com relação ao marxismo, Shariati posiciona como um movimento de tecnocratas e burocratas, no qual o foco é o poder, o capital e o trabalho.

Assadr argumenta que o marxismo mostra uma abordagem negativa referente à religião, já que acredita que o sistema é o produto e o resultado do conflito de classes da sociedade. O autor cita Ensaios Selecionados, de Marx:

"O sofrimento religioso na realidade, na realidade, é a expressão do sofrimento real e também ao mesmo tempo o protesto contra este sofrimento. A religião é o suspiro da criatura oprimida, o sentimento de um mundo cruel, de modo que é o espirito da falta de espirito. É o ópio do povo, assim sendo, a crítica a religião é o primeiro passo para a critica a esse vale de lágrimas".

De fato, o autor argumenta que Marx se esquece de uma realidade patente, que indica com toda clareza o fato de que a religião sempre cresce no seio dos miseráveis e paupérrimos e preenche suas almas, antes de inundar uma sociedade inteira. Aqui o autor reconhece o trabalho dos apóstolos, no sentido de que estes atenderam a necessidades espirituais de muitos. Para o autor, isso prova que não é o produto da fabricação de uma classe dominante, não foi inventado para drogar os excluídos e nem para a proteção de seu próprio interesse.

Para o autor, religião não é um fenômeno ideológico de uma sociedade de múltiplas classes, até mesmo as sociedades primitivas, que o marxismo acha que foram comunistas em sua natureza, prática e ideologia religiosa. Assadr defende ainda que a religião cresce entre os miseráveis, já que somente essa ideologia pode iluminar a alma humana e assim mudar a sociedade.

Outro ponto em defesa da religião colocada pelo autor é que, se realmente fosse uma criação das classes superiores com o intuito de manipular o homem, a religião não atuaria de forma a mudar a sociedade no auxílio dos mais necessitados, como por exemplo, na luta contra a usura. Para o autor, se a religião fosse uma ideologia somente da classe oprimida os burgueses não a aceitariam ${ }^{229}$.

229 "Quando é verificado que existia na vida do homem racional antes da estrutura de classes surgir, e "antes que o vale fosse coberto de lágrimas" da humanidade expressivamente explorada. Então como o marxismo conseguirá tornar a formação econômica a base de explicação para a religião? E há outra coisa. Se a religião fosse a ideologia dos oprimidos e dos explorados, surgindo da realidade de seu estado de miséria como o marxismo supõe na segunda versão de sua explicação para ela, então como seria possível explicar a existência da crença religiosa separada 


\subsubsection{Filosofia e Marxismo}

A filosofia de acordo com o marxismo também é uma manifestação intelectual da vida material e das condições econômicas em que a sociedade vive e com a evolução das forças produtivas haverá uma evolução no pensamento ${ }^{230}$.

Assadr parece compreender que os meios de produção foram mudando e tomando novas formas e com isso inculcou na mente dos filósofos a concepção de evolução que transferiu a teoria filosófica estática da natureza para a visão revolucionária que corresponde à evolução contínua nos meios de produção, ou seja, que as ideias filosóficas e pontos de vista irão mudar com os meios de produção.

Assadr reconhece essa relação entre filosofia e forças produtivas, mas ele irá se diferenciar do marxismo no sentido de não aceitar a causa econômica como a única causa por trás da filosofia. Para comprovar seu argumento, o autor irá citar diversos filósofos,

do estado real de miséria e da circunstâncias e condições de opressão econômica? E como seria possível que a classe não explorada nem oprimida aceitasse da classe dos oprimidos uma ideologia que surgia de sua realidade econômica e da religião pregavam? O marxismo não pode negar a existência da religião nas pessoas não relacionadas às circunstâncias de opressão econômica e a firmeza do apego à fé no coração de algumas dessas pessoas ao grau de sacrificarem suas próprias vidas por sua causa". (ASSADR, 2012, p.106)

${ }^{230} \mathrm{O}$ autor cita Morris Cornforth: O progresso da ciência para a concepção evolucionista, e que expressa a descoberta da evolução real da natureza e da sociedade, correspondeu ao desenvolvimento do capitalismo industrial na segunda parte do século XVIII. Obviamente, essa correspondência não foi uma mera correspondência, mas, expressou um nexo causal. A burguesia não teria sobrevivido se não tivessem sido produzidas contínuas mudanças revolucionárias nos modos de produção. Foram essas condições que levaram ao surgimento da concepção geral da evolução da natureza e da sociedade. Por causa disso a importância da filosofia na generalização das leis de mudança e evolução, não resultou apenas das descobertas científicas mas, foi relacionada a cada movimento da nova sociedade em seu conjunto. (ASSADR, 2012, p.110) 
que inclui Anaximandro ${ }^{231}$, Heráclito ${ }^{232}$, Sadr al-Din Shirazi ${ }^{233}$, cujas ideias filosóficas foram as mesmas que se encontravam na filosofia materialista do século XVIII.

Em conclusão, se o marxismo é verdadeiro em sua concepção de que a filosofia e as forças produtivas devem manter o mesmo ritmo, as ideias filosóficas destes filósofos não teriam sido as mesmas para a filosofia do século XVIII.

\subsubsection{Ciência e Marxismo}

O autor tem na questão da ciência e marxismo uma visão semelhante à da visão filosófica, isto é, todas as ciências naturais estão progressivamente avançando e crescendo em correspondência com as necessidades materiais, ou seja, Assadr reconhece a relação entre progresso científico e forças econômicas. No entanto, ele desconsidera a causa econômica como a alma por trás do progresso científico.

Assadr argumenta que, exceto nos tempos modernos, todas as sociedades que existiram antes eram em grande parte da mesma forma como os seus meios e modos de

${ }^{231}$ [...] o filosofo grego Anaximandro, que viveu no século VI a.C.. deu à filosofia uma concepção de evolução que não era diferente em essência das concepções de evolução predominantes na era da produção capitalista . Ele afirmou que as criaturas em seu primeiro estado eram coisas inexpressivas que em seguida impelidas pelo poder de sua força inata moveram-se pelo processo evolucionário para estágios mais e mais altos numa harmonia entre seu próprio ser e o ambiente externo. $\mathrm{O}$ homem, por exemplo, era um animal aquático, mas quando a água diminui seu nível foi obrigada a procurar um ambiente apropriado". (ASSADR, 2012, p.111)

232 "Heráclito, que teve participação nas concepções da evolução filosófica, foi um grande pensador. Mesmo o marxismo o considera um expoente destacado dos fundamentos da dialética e estima enormemente seus pontos de vista a respeito da teoria da evolução. Heráclito viveu no séc. V. a.C. e deu ao mundo da filosofia a concepção da evolução baseada nos opostos e na dialética. Afirmou que a natureza não permanece um estado imóvel mas num contínuo fluxo. Esta mudança de uma forma para outra e o movimento são a realidade da natureza, pois as coisas causarão a mudança de um estado para outro até o fim dos tempos: e explica esse movimento pela lei dos opostos que significa que uma coisa em movimento "é" e está mudando, ou seja, 'existente e não-existente ao mesmo tempo, e essa união de dois tempos, de existência e não-existência é o significado do movimento que é a essência da natureza e sua realidade. Essa filosofia de Heráclito, se prova algo, é o que o marxismo estava equivocado em sua explicação da filosofia e em sua ênfase sobre o alinhamento do progresso do modo de produção e as descobertas técnicas". (ASSADR, 2012, p.111-112)

233 " [...] quando apresentou-se ao pensamento muçulmano com a mais profunda filosofia que a história do pensamento já tinha testemunhado, e estabeleceu com sua filosofia o movimento essencial da natureza e contínua evolução na essência do universo baseado na filosofia da abstração. Ele determinou isso nos dia em que os modos de produção estavam, ainda estagnados na forma tradicional e que todas as coisas na vida se encontravam em imobilidade, ainda assim a orientação filosófica o impeliu à afirmação da lei da evolução da natureza diante de tudo isso. E em seguida que não há nenhuma relação inevitável entre a concepção filosófica e as formas econômicas das forças produtivas". (ASSADR, 2012, p.112) 
produção ${ }^{234}$. A agricultura e o artesanato foram duas formas de produção nestas sociedades. Em sua visão, se as formas de produção foram iguais, então por que há diferença no processo científico ${ }^{235}$ ?

$\mathrm{O}$ autor ainda argumenta que embora as necessidades sociais e materiais resultem em novas invenções e descobertas, isso não pode ser interpretação legítima da história e seu progresso. Isso simplesmente existe pelo fato de que muitas necessidades permaneceram milhares de anos à espera da ciência para cumpri-las.

\subsubsection{Os Fatores Físicos e o Marxismo}

Para o autor, um dos pontos mais problemáticos da hipótese marxista é a questão da não consideração dos fatores fisiológicos, psicológicos e físicos. Estes pontos não têm um papel na análise histórica ${ }^{236}$.

Assadr procura se justificar através da história. Ele irá argumentar que não foram os meios de produção e as condições econômicas que formaram o temperamento especial

\footnotetext{
234 "Sua simples existência na vida material humana não as capacita a alcançar alguma parte da ciência, até que o tempo chegue para que a própria ciência alcance um grau determinado para a satisfação dessa necessidade. Ocorria que a ciência estava a frente das necessidades sociais em suas conquistas quando haviam condições ideais para uma nova conquista ser realizada". (ASSADR, 2012, p.123)

235 “"...] se as formas e instrumentos de produção fossem os fatores principais que determinassem o conteúdo do conhecimento (científico) de cada sociedade e o progresso do movimento da ciência de acordo com o grau de desenvolvimento histórico, então não seríamos capazes de achar a explicação para tal diferença, tampouco justificativa para o florescimento da ciência numa sociedade, de modo superior à outra visto que a força principal que faz a história é única em todas as sociedades. Então, porque a sociedade europeia da Idade Média foi diferente, por exemplo, das sociedades islâmicas na Espanha, no Iraque ou no Egito, quando a base delas foi do mesmo gênero? E porque o progresso cientifico nas sociedades islâmicas floresceu em diferentes áreas num grau relativamente alto enquanto nenhum vislumbre disse se verificou na Europa Ocidental que estava perplexa com o que viu da nação Islâmica, durante as Cruzadas, em relação à ciência e a civilização? E porque foi que a China antiga foi capaz de inventar a imprensa, o que nenhuma outra sociedade conseguiu fazer, mas teve que adquirir este invento através dela?" (ASSADR, 2012, p.122)

236 "Todos sabemos o papel que os talentos militares de Napoleão e seu excepcional valor desempenharam na vida da Europa. Todos conhecemos algo a respeito da instabilidade de Luís XV e o efeito disso nos sete anos de guerra que a França lutou ao lado da Áustria. Foi uma mulher, como Madame Pompadour, que foi capaz de possuir a vontade do rei e consequentemente impelir a França à aliança com a Áustria na guerra para suportar o fardo das duras consequências que enfrentou. Todos sabemos do papel histórico que o episódio de amor especial que o Rei inglês, Henry desempenhou, resultado na renúncia do credo católico pela Família Real e posteriormente do povo inglês. Todos sabemos o que o amor paternal fez, o qual impeliu Muawiyah Ibn Abu Sufian à adoção de todos os métodos possíveis para obter o juramento de fidelidade para filho, Yazid". (ASSADR, 2012, p.132)
} 
do rei Luís XV. Pelo contrário, se tivessem as condições naturais e psicológicas ajudado, ele poderia ter sido um homem de força de caráter como Luís XIV ou como Napoleão. Para o autor, esse temperamento peculiar e características físicas são qualidades mentais e fisiológicas das quais sua existência, constituição específica e personalidade distintiva se formaram.

Sua visão mostra que os indivíduos possuem papéis na história que são determinados pela natureza e pelos fatores psicológicos e não pelas forças de produção que governam a sociedade. São estes papéis históricos que os indivíduos desempenham segundo sua formação particular que podem, em muitos acontecimentos, ser determinantes, não as questões econômicas.

\subsubsection{O Valor do Trabalho}

O marxismo mantém a opinião de que as matérias primas por natureza não possuem valor de troca. $\mathrm{O}$ valor de troca de uma matéria-prima natural passa a existir apenas como resultado da retificação do trabalho humano ${ }^{237}$. As proporções em que eles são trocados podem ser sempre representadas por uma equação em que uma determinada quantidade de milho é equiparada a alguma quantidade de ferro.

Se deixarmos de fora o valor de uso da mercadoria, tem-se apenas uma propriedade que é a deser sendo produto do trabalho. Assim, o trabalho é a base do valor de troca. No entanto, esta lei no marxismo não se aplica em caso de acumulação. Da mesma forma, esta lei não é aplicável no caso de algumas produções técnicas e monumentais, como uma placa produzida por um artista hábil em dívida ou uma carta manuscrita, que remonta a centenas de anos.

De acordo com Assadr, o trabalho não é a base do valor de troca. O autor argumenta que duas pessoas podem criar dois valores da mesma mercadoria, em intervalos de tempo iguais, devido à diferença na sua aptidão mental, desejo de sobressair sobre os outros e os tipos de sentimento que abrigam em suas mentes sobre esse trabalho em particular.

\footnotetext{
237 "Ele considerou o trabalho uma base de valor de troca entre as sociedades primitivas. Porém, certamente foi Ricardo quem deu à teoria o sentido de abrangência e acreditou que o trabalho é a fonte geral do valor de troca. Em seguida veio Marx, seguindo seu caminho nesse modo de Ricardo, mas que quando de sua adoção, a moldou dentro de uma estrutura conceitual peculiar". (ASSADR, 2012, p.164)
} 
Para o autor, dois pintores, cada um dos quais tem uma hora para pintar um quadro, possuem uma capacidade natural que faz com que o quadro pintado por um seja mais charmoso do que pintado pelo outro. Assim Assadr considera funcionar um fator heterogêneo que inclui unidades de esforços, que diferem em importância e variam em grau e valor. Para o autor é uma loucura medir quantitativamente o trabalho e numericamente sozinho.

O autor ainda argumenta que é possível a troca de uma produção técnica ou monumental a um ritmo mais elevado do que o que tem sido gasto com ele na forma de trabalho. Da mesma forma, Assadr argumenta que o marxismo não explica a queda do valor de troca de uma mercadoria com a diminuição do desejo ou demanda coletiva por ele.

O valor da mercadoria cai, apesar do fato de que a quantidade de trabalho coletivo envolvido lá permanece inalterado. Assadr argumenta que o grau de utilidade de uma mercadoria e até onde ela satisfaz a necessidade de uma pessoa têm uma influência sobre a constituição do valor de troca. Ele conclui que não é o trabalho, mas o desejo humano coletivo que é o fator comum entre duas coisas. Se o desejo de um determinado produto aumenta, pode-se pagar todos os preços para obtê-lo. Assim não é certo, mas é o desejo humano com base na qual a troca de produtos tem lugar.

\subsubsection{Assadr Sobre o Comunismo Primitivo}

Após a investigação de muitas sociedades contemporâneas, o marxismo propõe a visão de que a humanidade passou por um estágio primitivo do comunismo no início da vida em sociedade e essas condições primitivas permanecem na sociedade até hoje. Estas sociedades incluem a maioria das tribos da África, Polinésia, Austrália, entre outras.

Com isso, Assadr observa que, se essas sociedades são aceitas como primitivas, vai contra a lei da inevitabilidade da história em que o próprio sistema marxista acredita, segundo a qual, as sociedades têm continuamente se movido de um estágio para outro. $\mathrm{O}$ autor argumenta que estas sociedades primitivas podem permanecer assim por milhares de anos, sem nenhum desenvolvimento.

O marxismo explica a natureza e características das relações de propriedades 
nestas sociedades ${ }^{238}$ e levanta que a produção em pequena escala estava por trás da causa da vida comunal. Para o autor, o marxismo também se contradiz enquanto fala sobre as disposições morais da sociedade comunista e glorifica suas virtudes.

Para o autor, o nível de produção nas sociedades as quais é declarado que havia o comunismo primitivo era alto, já que podia suprir a necessidade dos que não trabalhavam. Então não há porque deduzir que ali havia o comunismo primitivo ${ }^{239}$. Assadr defende que não ocorreu a ninguém a ideia de exploração e fraude em termos de distribuição destas mercadorias produtivas, devido à consciência dessas pessoas e não pelo fator econômico ${ }^{240}$.

Se a distribuição igual foi o resultado da escassez da produção e no início havia um modo igualitário de distribuição com receio de que alguém morresse de fome e que com isso perdessem a um ajudante frente ao trabalho de produção social, então porque se empenhavam para sustentar os indolentes com cuja perda eles nada perderiam? (ASSADR, 2012, p.142)

Assadr declara que devido à constituição psicológica e fisiológica especifica do ser humano, o comunismo é inadequado ao homem e todas as complicações ocorridas na

238 "O marxismo explica as relações da propriedade comunista na sociedade primitiva dos seres humanos com o estágio primitivo no qual as forças de produção estavam naquele tempo e as condições predominantes da produção. Os seres humanos eram obrigados a seguir a produção numa forma social conjunta e em grupo enfrentar a natureza, devido à fraqueza do homem e a escassez dos meios. A cooperação na produção necessita do estabelecimento da propriedade comunal e proíbe a ideia de propriedade privada. Portanto, a propriedade há de ser comunal, pois a produção é comunal; e a distribuição entre os indivíduos também será baseada na igualdade por causa das condições de produção. Pois o baixíssimo nível das forças de produção fazia a distribuição do alimento escassa, e as mercadorias simples em porções obrigatoriamente iguais. $\mathrm{O}$ estabelecimento de qualquer outro modo de distribuição era impossível, porque qualquer individuo que adquirisse uma parte excedente à parte dos demais levaria os outros à fome. (Evolução da Sociedade Privada)" (ASSADR, 2012, p,140)

239 “"...] estes grupos primitivos consideravam que não prestar ajuda a alguém que necessitava um grande crime e desprezavam a quem fizesse tal coisa. Ele cita, com a autoridade de Catalin, que todo indivíduo de uma aldeia (quer seja homem, mulher ou criança) tinha o direito a entrar em qualquer moradia e comer se estivesse faminto, e mais, aqueles que estivessem fisicamente incapacitados (ou preguiçosos) de trabalhar ou caçar, sendo capazes de fazê-lo, a despeito disso tinham o direito de entrar em qualquer casa que desejassem e partilhar o alimento com seus moradores. Por isso um indivíduo obtinha comida nestas sociedades, não importando o quanto se omitia de suas obrigações com respeito à produção do alimento, e nada podia resultar em sua deserção exceto seu próprio sentimento para com uma notável perda de sua dignidade. (Evolução da Sociedade Privada)" (ASSADR, 2012, p.141)

240 "Se as forças de produção permitiam a exploração em tais sociedades, devemos encontrar a razão para o seu não-surgimento, ao grau de consciência e da ideia prática do homem primitivo. De fato, a ideia da exploração chegou a ele, como uma tardia manifestação desta consciência e ideia prática, como produto de seu progresso e do aumento de seu conhecimento da vida". (ASSADR, 2012, p.141) 
Revolução Russa demonstram isso ${ }^{241}$.

\subsubsection{A Escravidão}

A sociedade comunista emerge como resultado do desenvolvimento das forças de produção, pois devido ao aumento das forças produtivas o homem foi capaz de atender às suas necessidades de trabalho em uma porção limitada de tempo, mas como as forças produtivas estavam exigindo mais trabalho, a escravidão foi surgindo para atender as novas exigências destes novos tempos.

Em sua visão, o marxismo tenta explicar o nascimento de escravidão, mas com isso contradiz o próprio materialismo histórico, colocando que os fatores políticos foram mais importantes que os fatores econômicos, na emergência da escravidão ${ }^{242}$.

Para Assadr, não foi o fator econômico que trouxe a escravidão, mas a natureza do ser humano que sempre busca o conforto e lazer. O homem quando tem dificuldades, sempre irá buscar a maneira mais fácil, e a escravidão forneceu ao ser humano um modo de viver como gostaria.

\subsubsection{Sobre a Sociedade Feudal}

De acordo com o marxismo a sociedade escravista emergiu dentro da sociedade feudal como o resultado brutal da exploração dos escravos por seus mestres. Com isso, milhares perderam suas vidas. Além disso, a conversão da maioria dos agricultores e artesãos independentes diminuiu o número de soldados nas forças armadas, o que

\footnotetext{
241 "Em suma, o crescimento das forças produtivas não estava condicionado ao caráter escravista do trabalho. Então, porque o homem social multiplicou o trabalho pelo método da conversão de metade da sociedade em escravos, e não o realizou pelo método do acordo mútuo livre - para a multiplicação do trabalho? Não encontraremos resposta para esta questão exceto a partir do próprio homem e de suas tendências físicas. O homem é, por natureza, favoravelmente disposto a economizar o esforço e seguir o caminho mais fácil para seu objetivo. Assim que ele depara com dois meios para atingir sua meta, certamente escolherá o menos difícil. Esta tendência original do homem não é resultante dos meios de produção, mas sim, produto de sua própria composição". (ASSADR, 2012, p. 144)

242 "As duas coisas não estão de acordo com o ponto de vista do materialismo histórico, a primeira leva a se considerar o fator político como principal e o fator econômico como um fator menor que surge do primeiro, porque supõe que foi a posição política que os líderes, sacerdotes e chefes militares possuíam na sociedade comunista sem classes, que lhes franqueou o caminho para o enriquecimento e a criação da propriedade privada". (ASSADR, 2012, p.146)
} 
consequentemente diminuiu o número de escravos fornecidos ${ }^{243}$. Com isso houve um conflito violento entre a escassez da oferta de trabalho e a crescente demanda das forças produtivas, o que levou a um conflito de classes.

O autor tenta mencionar a transformação da sociedade romana de ordem escravista à ordem feudal como argumentação de uma transformação voluntária por parte da classe principal sem a necessidade de uma revolução ${ }^{244}$.

Assadr argumenta que a transformação não é o resultado necessário do desenvolvimento das forças produtivas, a mesma agricultura encontrada na forma escravista que continuou no sistema feudal. Contrário a isso, a sociedade primitiva sofreu mudanças drásticas nas forças de produção. O homem primitivo costumava recorrer ao uso de pedras na forma para a sua atividade produtiva, e então recorreu aos implementos feitos de pedra.

Em sua visão, as forças de produção se desenvolveram e os implementos de metal e o arco e flecha surgiram. Mais tarde, os produtos da agricultura e em seguida os produtos derivados dos animais e essas grandes transformações dos modos de produção foram aperfeiçoadas e se formaram numa sequencia ininterrupta de desenvolvimento sem que tenham sido acompanhadas de transformação social ou mudanças nas relações comuns ${ }^{245}$.

243 “[...] essas relações converteram gradualmente a maioria dos agricultores e artesãos independentes em escravos. Portanto, a sociedade perdia - em razão disso - forças armadas e soldados dentre os homens livres de cujos contínuos ataques a sociedade costumava obter um fluxo ininterrupto de escravos produtivos. Assim, a ordem escravista resultava de dentro da designação de novas forças produtivas pelo sistema de cativeiro. Por causa disso um violento conflito surgiu entre ela e as forças de produção, a sociedade escravista ruiu e a ordem feudal a sucedeu." (ASSADR, 2012, p.147)

244 "A transformação (conversão) da sociedade romana, por exemplo, do sistema escravista para o feudal não foi resultado de uma revolução de classe num dos momentos compartimentados da história a despeito do fato da revolução ser uma lei inevitável do materialismo histórico, pois todas as mudanças sociais (transformações), segundo a lei dialética (alei dos saltos de evolução), são mudanças quantitativas graduais transformadas subitamente numa mudança qualitativa. Desse modo, esta lei dialética tornou-se inoperante e não efetivou a transformação da sociedade escravista em sociedade feudal numa forma periódica revolucionária de modo súbito, a sociedade seguiu de acordo ao esclarecimento do próprio marxismo, transformou-se através dos próprios senhores que uma vez efetuaram a emancipação de uma grande parte de seus escravos, dividindo muitas terras, estabelecendo-as em pequenas porções e entregando-as aos antigos escravos já que haviam percebido que o sistema escravista não mais assegurava seus interesses. (Evolução da Propriedade Individual)" (ASSADR, 2012, p.148)

245 "[...] pode ter sido possível que os modelos de produção mudassem enquanto a forma social permanecesse inalterada como na sociedade primitiva, por exemplo; e se na sociedade mudou enquanto os modos de produção permaneceram fixos como observamos no caso do sistema escravista e o sistema feudal, então qual é esta necessidade que enfatiza a afirmação de que toda formação social é correlata a um modo definido e uma fase da produção particular?" (ASSADR, 2012, p.151) 
Para o autor, uma mudança na sociedade não leva necessariamente ao progresso e desenvolvimento. Assadr argumenta que, em vez de ocorrer um efeito positivo, o feudalismo em sua visão foi negativo, já que para ele, houve uma acomodação. Os senhores feudais permaneceram naquele estado disputando os rendimentos agrícolas com seus produtos simples e assim houve uma queda da qualidade de vida, trazendo grande pobreza entre as pessoas.

\subsubsection{Sobre o Levante de Uma Sociedade Capitalista}

De acordo com o marxismo, o sistema econômico capitalista surgiu como resultado da desintegração do sistema econômico feudal. Segundo Assadr, o marxismo, ao analisar o capitalista histórico, dá muita importância à acumulação primitiva do capital $^{246}$, sendo que na visão do autor, dar ênfase demasiada à acumulação primitiva é negar o ponto de vista convencional de economia política que afirma que a produção do capital e da riqueza necessária foi o resultado da inteligência e bom gerenciamento por uma classe da sociedade. Ou seja, Assadr fará aqui um discurso de resistência anticapitalista, similar a outro no mesmo período.

El-Ashker e Wilson (2006, p.150) argumentam que aqueles que "tentaram responder ao capitalismo, têm descoberto que seu poder não é somente um poder material, porém também imaginativo que ajuda a estruturar a maneira na qual as pessoas se comprometem com o mundo".

Em sua construção, Assadr tenta desconstruir as ideias sobre o capitalismo e sobre o marxismo, com o intuito de trazer um modelo para os muçulmanos que fosse realmente aceito.

Para o autor, a descrição marxista sobre o surgimento capitalista não se aplica a sociedades como a Alemanha, onde um grande número de feudalistas construíram fábricas, administraram e financiaram com a renda feudal e não houve violência ou

\footnotetext{
246 "Marx submeteu este ponto de vista clássico a um pungente ridículo e a grande depreciação, como de costume, ao tratar os pontos de vista aos quais se opunha. Tendo-o ridicularizado ele observa que o entesouramento somente não pode ser responsável pela existência do capitalismo. Para descobrir o segredo da acumulação primária do capital, no qual se baseava a nova classe, devemos examinar o significado do sistema capitalista em si e procurar em sua profundidade, pela (solução) do segredo. Nesse ponto, Marx recorre a seu talento e expressão singular, e seu total comando das palavras, a fim de apresentar seu ponto de vista". (ASSADR, 2012, p.154)
} 
qualquer movimento de usurpação ${ }^{247}$.

A explicação sobre o aparecimento do capitalismo argumentado pelo marxismo não é absoluto, já que em sua visão nega o materialismo histórico. Para Assadr, como os marxistas poderiam dizer que a razão por trás da acumulação primária e da existência da classe capitalista foi o poder de usurpação e subjeção, quando esta em si não é exatamente uma razão de natureza econômica ${ }^{248}$.

\subsubsection{4 "Crença Marxista”}

O "credo marxista"249 significa o sistema social que buscará materializar seus ideais para a sociedade através de dois estágios: o socialismo e o comunismo ${ }^{250}$. Do ponto de vista do materialismo histórico, a humanidade irá atingir o mais alto nível de desenvolvimento com base das leis da dialética e o mais alto nível deste estágio é conhecido como comunismo. No entanto, antes de atingir este estágio ele irá passar por um período transitório que seria o socialismo.

Durante este estágio algum governo será estabelecido, que irá nacionalizar os recursos de riqueza e os meios de produção capitalista. Desta forma, a sociedade sem classes irá emergir como um arranjo de distribuição, baseado no princípio de que cada

247 "Primeiro, essa descrição não se aplica às sociedades em que o capitalismo foi incumbido à classe feudalista, como aconteceu na Alemanha, por exemplo, onde um grande número de feudalistas construiu fábricas, as administraram e as financiaram com a renda que recebiam dos feudos. Não foi, portanto, necessário que a mudança ocorresse do feudalismo ao capitalismo seguindo um movimento de nova usurpação, já que os próprios feudalistas puderam realizar a produção do capital com base nas riquezas que tinham adquirido no início da história feudal. Do mesmo modo que a descrição marxista não se aplica ao capitalismo industrial que cresceu com a incumbência da classe feudal, também não é aplicável ao capitalismo mercantil que foi constituído com os lucros do comércio como aconteceu nas democracias mercantis da Itália como Veneza, Gênova e Florença". (ASSADR, 2012, p.156-157)

248 “'[...] suponha-se tal poder de subjugação e de violência não precise ser explicado, porém isso não é adequado para que seja um meio marxista para explicar o acúmulo primário de capital, e, por conseguinte, o sistema capitalista como um todo, pois não é uma explicação econômica, e, portanto, não é compatível com a essência do materialismo histórico". (ASSADR, 2012, p.157)

249 "Porque a doutrina em relação ao que o marxismo prega é na realidade apenas uma expressão legal e uma legislatura formal da curva histórica geral que é imposta pelo movimento do surgimento da produção, de suas leis e incompatibilidades. Então, quando o marxismo veste o manto da motivação doutrinal simplesmente expressa com isso à realidade histórica dessas leis". (ASSADR, 2012, p.196)

250 "Na doutrina marxista existem dois estágios que o marxismo exige - partindo do aspecto doutrinal para a materialização sucessivamente - e ressalta - do aspecto materialista histórico como também sua necessidade histórica. Estes dois estágios são o socialista e o comunista". (ASSADR, 2012, p.196) 
um terá de acordo com sua capacidade e trabalho.

O marxismo defende que a composição de classes é resultado da propriedade privada e quando propriedade privada for abolida, a sociedade se tornará uma única classe. Para Assadr ${ }^{251}$, a composição de classes não é necessariamente o resultado de um fator econômico e da posição da propriedade privada. As classes têm existido na história dentro do sistema militar, político e religioso. Portanto, historicamente isto não é necessário para que a divisão da sociedade em classes desapareça com o fim da propriedade privada, e é possível que uma composição de classe tenha lugar na sociedade socialista de outra forma.

O autor irá relembrar aqui seu estudo sobre o materialismo histórico, no qual defende que o fator econômico e o status da propriedade privada não são a única base de todas as composições de classe e, em sua visão, a natureza política e econômica do estágio socialista pode levar à criação de uma nova classe ${ }^{252}$, e esta pode ser inconsistente, assim como a distribuição econômica do estado socialista.

Para Assadr, há uma contradição na questão da distribuição para cada um segundo seu trabalho, já que os indivíduos são naturalmente diferentes em sua eficiência, devido a suas diferenças e capacidades, natureza do trabalho e grau de complicação. Portanto, um trabalhador talentoso, inteligente não pode ser equalizado com um trabalhador normal.

De acordo com Assadr, o marxismo encontra duas soluções para resolver o problema da remuneração. Primeiro: aderir aos princípio de distribuição que declara, "para cada um de acordo com seu trabalho" e, portanto distribui a produção entre o indivíduo com diferentes graus e cria uma nova dominação de classes, ou pode tirar o excedente do trabalhador talentoso como o capitalismo, a fim de equalizar os salários.

Para Assadr, a natureza política da sociedade socialista também cria dominação

${ }^{251}$ Para se estudar a doutrina marxista o autor apresenta uma metodologia, que consta dos seguintes passos: $1^{\circ}$ critica dos princípios teóricos e as bases em que a doutrina se estabelece; $2^{\circ}$ estudo da extensão de aplicabilidade de tais princípios; $3^{\circ}$ a discussão da ideia essencial da doutrina com respeito a sua aplicabilidade. (ASSADR, 2012, p.198)

252 "“...] se faz necessário que os revolucionários, as lideranças e aqueles que se encontram na órbita do partido, exerçam a autoridade numa forma ilimitada para que possam obrar o milagre da criação do novo homem. Quando chegamos a este estágio do experimento socialista, verificamos que esses líderes, no partido e no quadro político como seus defensores, gozam de tais possibilidades que a maioria das classes jamais tiveram em toda a história, já que adquiriram autoridade absoluta sobre todas as propriedades e meios nacionalizados de produção, como também um centro político os habilita a se beneficiar de tais propriedades e manejá-las de acordo com seus interesses pessoais". (ASSADR, 2012, p.202) 
de classes com base na posse e privação do poder político. Sob o socialismo, muito pode estar concentrado na mão do Estado, e este não é apenas uma autoridade política, mas também exerce autoridade ilimitada na esfera econômica. Para Assadr, a propriedade em sua substânica real nada mais é que a autoridade sobre a riqueza e o poder, e ficará concentrada sobre o poder político no estágio do socialismo.

O mais alto estágio de desenvolvimento humano é o comunismo, sendo este o estágio final da história, no qual a sociedade se tornará uma única classe. Todas as lutas de classe vão chegar a um fim e todos os recursos serão igualmente distribuidos entre as pessoas. Segundo Assadr, há dois pilares do comunismo, de acordo com o marxismo: primeiro, acabando com a propriedade privada não só no campo capitalista de produção, mas também no campo de consumo, nacionalzando todos os meios de produção e todos os bens de consumo ${ }^{253}$. O segundo pilar é a eliminação da autoridade política e, finalmente, a libertação da sociedade das garras do governo.

O autor é irônico dizendo que esta é uma "hipótese imaginativa e ampla de que todo homem na sociedade socialista esteja apto a satisfazer todos os seus desejos e necessidades". Para Assadr, o comunismo quer operar uma obra de milagres na personalidade humana, transformando as pessoas a despeito do desaparecimento dos impulsos pessoais e do ego à sombra da nacionalização. Para o autor, é uma tentativa de criar o paraíso na terra, retirando do homem o espírito de cobiça, a maldade, a parcimônia.

Quanto ao aniquilamento da propriedade privada em todos os campos, Assadr afirma que não deriva a sua existência na doutrina da lei cientifica de valor, como a nacionalização dos meios de produção capitalista é baseada na mais valia. Em vez disso, a ideia é baseada no pressuposto de que, a sociedade vai atingir um alto grau de riqueza, que as forças de produção irão crescer e consequentemente, não sobra espaço para a propriedade privada. Portanto, a distribuição será baseada no princípio de cada um segundo sua capacidade, para cada um segundo sua necessidade.

253 "A ideia de nacionalização generalizada está baseada na hipótese de que a sociedade atinge um elevado grau de riqueza graças ao sistema socialista, e as forças produtivas também crescem enormemente em tal sistema, e, por conseguinte, não há lugar para a propriedade privada dos bens de consumo ou dos meios de produção, pois todo individuo na sociedade socialista consegue o que necessita e deseja consumir. Assim, qual seria a necessidade da propriedade privada? Com base nisto, o princípio de distribuição na sociedade socialista se apoia na máxima "a cada um de acordo com sua necessidade e de acordo com seu trabalho", isto é, a cada um é dado apenas o tanto que satisfaça suas necessidades, pois a riqueza possuída pela sociedade pode satisfazer todas as necessidades". (ASSADR, 2012 p.212) 
Assadr argumenta que a história nunca foi testemunha de um milagre até agora, foi resultado de milhares de pessoas inocentes buscando materializar os experimentos marxistas, sendo que o experimento permanece preponderante entre o socialismo e o comunismo, e expressa uma inabilidade de materializar o comunismo.

Como segundo pilar do comunismo o autor questiona como seria possível fazer um governo desaparecer. O autor questiona a ideia revolucionária contra o governo advinda de classes que não são representadas pelo governo. Assadr argumenta que se a mudança do socialismo para o comunismo é revolucionária, então qual a classe irá trazer o comunismo, a sociedade é apenas uma única classe no estágio do socialismo. No entanto, se a mudança é gradual, então contradiz as leis da dialética ${ }^{254}$.

O autor ainda argumenta que a mudança também contradiz a natureza da realidade, porque como pode um governo dar um golpe mortal em si mesmo, enquanto todos os outros governos sobre a face da terra aderem ao seu centro e defendem a sua existência política até o último momento de sua vida? Por último, Assadr argumenta que se o milagre do comunismo é dado de forma prática, então a sociedade não precisa de uma autoridade para regular a distribuição adequada de trabalho e os problemas relacionados a ele?

\subsubsection{As Características Mais Importantes do Capitalismo na Visão de Assadr ${ }^{255}$}

O capitalismo é um sistema econômico no qual a produção e a distribuição dos produtos e serviços são de posse privada e é chamado de sistema da livre iniciativa, já

\footnotetext{
254 "Temos o direito de apresentar uma questão sobre esta mudança que move a história da sociedade e estado para uma que seja livre dele, de um estágio socialista para um comunista: como esta mudança social ocorrerá? E se ocorrerá por uma via revolucionária, será de maneira que a sociedade passará do socialismo para o comunismo num momento decisivo como mudou do estágio capitalista para o socialista? Ou a mudança ocorrerá de modo gradual, em que o estado enfraquecerá e se escolherá até desaparecer? Então, se a mudança for revolucionária e simultaneamente o proletariado for aniquilado pela revolução, que classe revolucionária realizará esta mudança?" (ASSADR, 2012, p.214)

255 "Comumente se diz que a divergência entre as duas doutrinas, em seus marcos fundamentais, reflete a diferença existente na natureza do ponto de vista do qual veem o indivíduo e a sociedade, posto que a doutrina capitalista é uma doutrina individualista, que exalta os impulsos pessoais e considera o indivíduo sendo como o eixo central, cujos interesses são determinantes sobre a doutrina para o trabalho e cujos interesses devem ser assegurados". (ASSADR, 2012, p.221)
} 
que é possível um indivíduo investir livremente seu capital ${ }^{256}$. Neste sistema, os compradores e vendedores são livres para a troca de bens e serviços.

Em sua forma industrial, o capitalismo se desenvolveu na Inglaterra no século XIX e se espalhou pela Europa, América do Norte, Austrália, Nova Zelândia e África do Sul e, mesmo apesar de diversas manifestações, acabou se tornando o sistema dominante no mundo.

Os meios de produção, as fazendas e fábricas estão sob a propriedade privada, nas mãos de indivíduos e empresas. O homem está livre para usar seus bens ou não, sem nenhuma interferência.

O desejo pelo lucro e acúmulo de capital motiva a ação do mercado, o uso da propriedade privada e dos meios de produção. O indivíduo dentro do sistema está livre para adotar qualquer linha de produção e é livre para adotar qualquer tipo de contrato com outros indivíduos, já que o homem praticamente não atua de forma cerceada pelo governo.

$\mathrm{Na}$ economia capitalista, o que produzir, como produzir e para quem produzir, todos os problemas considerados centrais da economia, são organizados pelas demandas de oferta e produção.

\subsubsection{Economia Capitalista e sua Natureza}

O autor divide o sistema capitalista em científico e doutrinário para o desenvolvimento de sua análise, assim como o fez com o sistema marxista. Assadr não visualiza o capitalismo como um produto de leis científicas ${ }^{257}$, pois as leis naturais são consideradas pelo autor como sendo sem falhas. Portanto, é um equívoco tomar as liberdades capitalistas como uma expressão de leis naturais e considerar a violação destas como um crime.

\footnotetext{
${ }^{256}$ Para o autor há um aspecto científico no capitalismo qu busca explicar o curso da vida econômica e seus eventos de uma maneira objetiva, baseada na análise e há também na economia capitalista o aspecto doutrinário, a materialização do que o capitalismo se propõe.

257 “"...] duas noções permeavam a ideologia econômica. 1. A vida econômica prossegue de acordo com as forças naturais limitadas, que dominam todas as entidades econômicas da sociedade bem como os variados aspectos da existência, de acordo com forças naturais diversas. O dever científico frente a estas forças constitui descobrir suas leis gerais e regras fundamentais que possam explicar de modo apropriado variados fenômenos e eventos econômicos. 2. Que aquelas leis naturais, que a economia deve descobrir, constituem garantia para a felicidade humana se forem aplicadas numa atmosfera de liberdade e quando todos os membros da sociedade se encontrarem capacitados aproveitar as liberdades do capitalismo: a liberdade da propriedade, da exploração dos recursos e do consumo". (ASSADR. 2012, p.223)
} 
Assim como Assadr, Taleqani (1983, p.56) também argumenta que é obvio que o objetivo das leis econômicas baseado nos princípios capitalistas é o aumento da riqueza, produção e lucro.

Assadr defende que o aspecto doutrinário depende apenas da moral e de certos valores práticos e ideias, que devem sozinhos ser considerados para se dar o veredito sobre sua doutrina. Assim, todas as discussões de seu livro partem do caráter doutrinário e não há lugar para o aspecto científico, pois quanto “à discussão científica no campo do exame do capitalismo doutrinário, não constitui a autoridade decisiva para dar o veredito em favor deste, já que não reivindica possuir o caráter científico ${ }^{258}$.” (Assadr, p.225)

Mannan (1995, p. 32), que também escreve sobre o capitalismo, não faz criticas no sentido científico, mas também vê o sistema como uma "religião do dinheiro, ou ditadura do dólar”. Para Mannan, os sistemas pré-capitalistas não eram orientados para a aquisição de riquezas materiais, mas o capitalismo em sua visão está centrado na individualidade e no risco pessoal, sendo que a liberdade demasiada do homem acaba por gerar um problema no sistema.

Segundo Assadr, o desejo do homem é determinado e condicionado de acordo com suas ideias e compreensão, bem como a ideologia doutrinária da sociedade em que vive e as sociedades se alteram de uma para outras e, para o autor, o capitalismo vive segundo estas leis, que estão ligadas à questão do desejo humano ${ }^{259}$.

Para o autor, as leis naturais para a vida econômica do homem não significam que este perca sua liberdade e sua vontade. Assim não devem ser consideradas como uma anulação da vontade humana. Assadr argumenta que "o trato da vontade humana com

\footnotetext{
${ }^{258}$ Para o autor, as leis científicas na economia capitalista pertencem a uma estrutura doutrinária. Assadr classifica as leis científicas em dois grupos: 1) as leis naturais que devem sua necessidade à própria natureza e não à vontade humana como a lei geral da limitação que diz que toda produção dependente da terra ou da matéria-prima tem seus itens limitados segundo a quantidade disponível de terra ou matéria-prima; 2) o grupo de leis científicas da economia política que compreendem as leis da vida econômica ligadas à vontade humana em si, em vista do fato que a vida econômica não é senão um dos fenômenos da vida humana em geral, na qual desempenha um papel crítico e positivo em diferentes aspectos e setores. (ASSADR, 2012, p.227-228)

259 “A inferência da vontade humana no curso da vida econômica não significa separação desta no âmbito de ação da lei científica ou a impossibilidade da discussão científica a seu respeito, como acreditaram alguns pensadores no início da economia política. Pois acreditaram que a existência obrigatória e necessária das leis científica se opunha à natureza da liberdade representada pela vontade humana. Portanto, se a vida humana estava sujeita às rígidas leis científicas, isto seria incompatível com a liberdade gozada pelo homem em sua vida. Por isso, quando sujeito a essas leis, ele se tornaria uma ferramenta trabalhando mecanicamente, de acordo com as leis naturais que controlam o curso de sua vida econômica". (ASSADR, 2012, p.228)
} 
estas leis é determinado e condicionado de acordo com as ideias e compreensão do homem, como também o são pela doutrina que esteja em voga na sociedade e a forma das legislações restritivas sobre o comportamento do indivíduo". (p.229)

De fato, na visão do autor, a vontade do homem pode alterar sua atitude prática que poderá alterar a tendência da vida e assim alterar as leis científicas gerais que explicam o rumo da vida econômica. Referente às leis econômicas, o autor declara que ela são universais, aplicáveis a qualquer sociedade e em qualquer período.

\title{
2.17.17 O Capitalismo Doutrinário
}

A economia capitalista, de acordo com o autor, tem sua base em três elementos: liberdade para a propriedade privada, liberdade de exploração e liberdade de consumo. Essa liberdade é garantida a todos os indivíduos no sistema capitalista de forma igualitária, sem nenhuma limitação ou restrição. Portanto, cada indivíduo tem a total liberdade para buscar qualquer abordagem ou caminho para adquirir, aumentar e multiplicar sua riqueza de acordo com seus interesses pessoais e na busca de seu beneficio $^{260}$.

Essa questão do consumo é muito debatida pelos estudiosos islâmicos, Professor Tavakali ressalta:

\begin{abstract}
"Esse tipo de sistema capitalista parece ter uma lacuna psicológica, que afeta as pessoas. Elas parecem ser ... Eu não sei ... se tornando mais ricos. Mas psicologicamente eles são menos felizes. Então, isso significa que essa taxa de pobreza está diminuindo, mas se o ritmo psicológico da pobreza não acompanha, porque ninguém tem o computador e você tem, algo está errado. Quando você vivia em uma espécie de pequena casa, com sua família isso parecia ter um impacto menor, mas ao buscar a necessidade de ter, isso impacta exponencialmente sua satisfação pessoal ao perseguir esse objetivo financeiro."
\end{abstract}

Para os estudiosos da economia islâmica, a felicidade não vem em si do ter, mas de outros valores e a crítica à liberdade é central em muitos destes pesquisadores. Para Assadr, sendo a ideia de liberdade o principal pilar do capitalismo, qualquer base e análise devem partir de um exame das origens ideológicas como também das ideias e valores em que se fundamentam. Aqui se tornam mais latentes, como ao autor vê, as diferenças entre

260 “[...] liberdade- com diferentes modalidades - é a base da qual se difundem todos os direitos e valores doutrinários proclamados pelo capitalismo" (ASSADR, 2012, p.233) 
o sistema capitalista e o sistema marxista. No primeiro, a propriedade privada e liberdade ilimitada ao indivíduo ${ }^{261}$, enquanto que no segundo, a abolição da propriedade privada e o sacrifício ao indivíduo para o bem da sociedade.

O autor propõe ideias questionáveis ao fazer a distinção entre as duas doutrinas com base no indivíduo, já que argumenta que ambas são individualistas em sua natureza, porque ambas dependem de pontos de vista individualistas e dependem de pontos de vistas pessoais e de ego. O capitalismo garante o ego individual dos seres humanos oferecendo total liberdade ${ }^{262}$ e o marxismo também foca no indivíduo que possui maior necessidade.

Assadr argumenta que a doutrina que merece o título de coletiva é a que dependa do poder de outras e não esteja ligado ao ego e aos impulsos pessoais. Uma doutrina que cultive no indivíduo uma consciência profunda a respeito da sociedade e seus interesses. O capitalismo como doutrina deve incumbir o indivíduo a abandonar alguns dos frutos de seu trabalho, fazer determinado esforço e dedicar pouco de riqueza privada para o bem da sociedade. Na verdade, essas garantias doutrinam os direitos dos indivíduos e garantem seu bem-estar. Todas estas características, de acordo com Assadr, estão presentes na doutrina econômica islâmica.

\subsubsection{A Liberdade Capitalista}

A pedra angular da doutrina capitalista é a liberdade do homem no campo econômico em seus vários ramos, tais como propriedade, exploração e consumo. Segundo Assadr, o capitalismo fornece três razões para tal liberdade ilimitada. Primeiro: a liberdade é um meio para a materialização dos interesses públicos. Segundo: a liberdade gera o crescimento da produção. Terceiro: a liberdade é a expressão real da dignidade humana.

O capitalismo acredita que, em uma sociedade livre, o homem luta para a

\footnotetext{
261 "As economias capitalistas foram levadas a crer no início, que assegurar os interesses e o bem estar da sociedade não seria necessário para inculcar os valores morais e culturais no povo, já que todo ser humano, mesmo aquele que nada sabia sobre isso, procederia de acordo com seu próprio interesse, quando a liberdade lhe fosse garantida no campo prático. Esse interesse segue lado com os interesses da sociedade e está em consonância com eles, embora o indivíduo seja influenciado por um impulso próprio". (ASSADR, 2012, p.235)

${ }^{262}$ Para o autor, a sociedade dispensou os serviços que a moral e os valores espirituais prestavam para satisfazer os interesses humanos e isso é preenchido pelo método capitalista.
} 
concretização de seus interesses pessoais, o que leva à promoção dos interesses gerais. Para o autor, o interesse pessoal é um forte incentivo e o objetivo real de um indivíduo em seu trabalho e atividade é o melhor o para bem-estar social geral, já que os interesses pessoais sempre motivam o indivíduo a pensar em maneiras de aumentar e melhorar a produção, diminuindo o seu custo e despesas. Isso satisfaz o interesse da sociedade, enquanto que ao mesmo tempo também é considerado adequado para o indivíduo. Portanto, de acordo com o capitalismo, o indivíduo é a base sobre a qual deve ser estabelecido o sistema social.

Porém, segundo Assadr, o capitalismo não considera necessário inculcar valores morais e espirituais entre as pessoas. Todo o ser humano, mesmo aquele que não sabe nada sobre esses valores procede de acordo com seus próprios interesses, quando a liberdade é concedida a ele $^{263}$. Consequentemente, os interesses sociais não se materializaram automaticamente.

Assadr argumenta que a liberdade capitalista desprovida de valores morais e espirituais tem mostrado consequências perigosas durante toda sua história ${ }^{264}$. Ele observa que não se pode subestimar os crimes e crueldades trazidas por sua liberdade desenfreada e o surgimento de falência moral e espiritual como resultado de sua neutralidade em relação a esses valores.

A liberdade absoluta, para o autor, tornou-se uma arma nas mãos dos poderosos para sugar o sangue dos fracos. Como resultado desta liberdade, a dignidade humana foi esmagada a tal ponto que o próprio homem tornou-se uma mercadoria e foi submetido à lei da oferta e da demanda. A opressão, tirania, ganância e exploração trazem a expressão de uma liberdade tão desenfreada e a situação tornou-se muito pior: a vida dos trabalhadores é perecer e morrer de fome, enquanto a economia capitalista fornece-lhes

263 “"...] foi possível para a sociedade dispensar os serviços que a moral e os valores espirituais prestam e satisfazer seus interesses por intermédio do método capitalista, que proporciona liberdade a todo indivíduo e o capacita a avaliar sua atitude considerando seus interesses pessoais que, finalmente se coaduna com os interesses coletivos. E é por esta razão que a liberdade proclamada pelo capitalismo é despida de todas as limitações e valores morais e espirituais, pois está isenta do julgamento desses valores". (ASSADR, 2012, p.235)

264 "Tratar sobre a harmonia entre os interesses coletivos e os impulsos pessoais, sob a proteção da liberdade capitalista, tornou-se hoje objeto de ridículo ao invés de algo aceitável, depois que a história do capitalismo foi marcada por lamentações, angústias e calamidades que tiveram pouco paralelo na história humana, gritantes incompatibilidades entre os interesses pessoais e coletivos e o vácuo colossal causado ao se prescindir dos valores morais e espirituais da sociedade, tendo como resultado o fato de que a sociedade foi permeada por diferentes tipos de opressão, imprudência e ambição". (ASSADR, 2012, p.236) 
um raio de esperança e uma abertura de luz ${ }^{265}$.

O autor reconhece como resultado dessa liberdade que os sentimentos de bondade e de fazer bem aos outros desapareceram e as tendências do egoísmo e da ganância emergiram. Na sociedade capitalista, em vez de cooperação e solidariedade, a luta pela sobrevivência tornou-se a tendência, e a liberdade iniciou uma corrida louca entre os países europeus para subjugar a humanidade pacífica e explorá-la para o serviço dos capitalistas.

Assim, conclui Assadr, que a humanidade sofreu terrivelmente nas mãos do capitalismo, devido à sua liberdade de vazio moral e vácuo espiritual. Para o autor, com uma base teológica, não é possível concretizar os interesses públicos, sem inculcar no homem os valores morais e espirituais.

O segundo ponto argumentado pelo capitalismo é que a liberdade leva ao crescimento de produção. Na visão dos defensores do capitalismo, a liberdade econômica abre o campo da livre concorrência para diferentes projetos de produção. Um projeto melhora e com isso atinge outros. Um dos meios importantes para alcançar a excelência é trazer melhorias técnicas no projeto, sendo que desta forma, novas invenções acontecem e a sociedade é beneficiada como um todo.

Para o autor, o primeiro erro é que as unidades do projeto na sociedade capitalista não são semelhantes, operando com igual grau de competência, mas são diferentes em termos de tamanho e competência. Tal natureza desses projetos leva à luta violenta em que os projetos fortes esmagam os mais fracos e, finalmente, resulta em monopolização ${ }^{266}$.

O segundo erro da noção capitalista está, para o autor, no aumento exponencial do

\footnotetext{
265 "Pois a moral não possui apenas valores objetivos, mas também um valor pessoal, o que não é menos importante do que seu valor objetivo no aperfeiçoamento da vida humana e na geração do espirito de felicidade e de bem estar pessoal". (ASSADR, 2012, p.238)

266 "[...] os projetos de produção da sociedade capitalista não constituem pequenas unidades, entrando em competição com um grau similar de competência e possibilidades, de maneira que cada projeto pode ser competente para enfrentar os demais projetos, o que constitui um fator que assegura a livre competição e por isso torna isso um meio para o crescimento e o melhoramento da produção. Mas, os projetos de produção nas sociedades capitalistas são de diferentes dimensões, competência e capacidade de fundirem-se uns aos outros. A liberdade capitalista em tal caso abre caminho para a competição, o que logo leva a um violento conflito em que os projetos mais fortes esmagam os demais e começam a monopolizar a produção gradualmente, até que todas as formas de competição e seus frutos se ocultam na insana corrida da produção. Portanto, a livre competição que promove a produção não acompanha a liberdade capitalista por muito tempo, mas, logo dá lugar à monopolização assim que a situação econômica é dominada pela liberdade capitalista". (ASSADR, 2012, p.240)
} 
nível de produção, já que esta não é a garantia de bem estar e felicidade da sociedade. Não é o aumento da produção, mas, a sua distribuição adequada, que constitui toda a impressão de bem estar social geral.

A liberdade como uma expressão da dignidade humana, se estendeu pela sociedade capitalista. Segundo Assadr, os capitalistas usam o conceito de liberdade de uma forma errada, pois em sua visão temos dois tipos de liberdade, a natural ${ }^{267}$ e social. A liberdade natural é dada por natureza, enquanto que a liberdade social é concedida pelo sistema social em que a pessoa vive.

De acordo com o autor, liberdade natural é justamente o elemento essencial da dignidade do ser humano. No entanto, não tem caráter doutrinário. É um benefício conferido ao homem por Deus e não um dom fornecido por qualquer doutrina. Quanto à liberdade social, o que acarreta caráter doutrinário é o fato de que o indivíduo a recebe a partir da sociedade. Aqui, novamente Assadr divide em duas formas: a liberdade social essencial e a outra liberdade social formal ${ }^{268}$.

A liberdade social essencial é um poder que um indivíduo ganha da sociedade para fazer um determinado trabalho e a sociedade fornece ao indivíduo todos os meios e as condições requeridas para isso ${ }^{269}$. Portanto, a sociedade garante a um indivíduo de possuir uma mercadoria e de torná-la disponível no mercado. Além disso, não se pode monopolizar essa mercadoria e um indivíduo é livre para comprá-la.

A liberdade formal significa que a sociedade permite que um indivíduo no âmbito de suas possibilidades e oportunidades possa adotar qualquer método para comprar uma

267 "Essa liberdade natural que o homem possui é considerada um dos elementos essenciais da natureza, já que constitui uma expressão de sua força básica. Portanto, humanidade, sem esta liberdade, se tornaria uma palavra sem sentido". (ASSADR, 2012, p.243)

268 "Ao analisarmos o significado da liberdade social encontramos seu verdadeiro conteúdo e sua forma externa. Ela possui dois aspectos, um, o verdadeiro conteúdo ou a liberdade essencial, como expressaremos mais a frente, e o segundo, o aspecto externo que pode se chamado de liberdade formal. Assim, existem dois tipos de liberdade social. A essencial e a formal. (ASSADR, 2012, p.244)

269 "No que se refere a liberdade social essencial, significa o poder que uma pessoa adquire na sociedade para fazer uma determina coisa. Isto significa que a sociedade proporciona ao indivíduo todos os meio e condições necessárias para fazer algo. Portanto, se a sociedade assegura a alguém a posse do valor de uma mercadoria em particular, tornando essa mercadoria disponível de modo abundante no mercado e não dando a ninguém o direito de monopolizar a compra desta mercadoria, a pessoa em questão está livre para adquirir a mercadoria, pois socialmente ela goza de todas as condições das quais a compra desta mercadoria depende. Mas se a sociedade não capacita esta pessoa a possuir o valor da mercadoria, não assegura a oferta desta mercadoria no mercado ou dá a outro o direito exclusivo de compra da mesma, então a pessoa não tem na realidade a liberdade essencial ou o verdadeiro poder de compra". (ASSADR, 2012, p. 244) 
determinada mercadoria. Na base dessa liberdade, um indivíduo é livre para comprar qualquer coisa se ele possui os meios para comprá-la. Uma pessoa é livre para comprar uma caneta ou uma grande empresa. Assim, a liberdade formal é um meio de força em um indivíduo para o desenvolvimento da sociedade, embora não ofereça qualquer garantia de sucesso para ele $\mathrm{e}^{270}$.

Para o autor, a liberdade essencial social e a liberdade social formal são contraditórias, o capitalismo adota uma atitude negativa para com a liberdade essencial social e a considera como a capacidade de se beneficiar da liberdade e não a própria liberdade ${ }^{271}$. Assadr considera esta atitude negativa do capitalismo no sentido da liberdade social essencial, como um resultado inevitável da sua atitude positiva para com a liberdade social essencial.

De acordo com Assadr, não é possível para qualquer doutrina econômica, fornecer ambas as liberdades simultaneamente, porque a liberdade social essencial exige freio ${ }^{272}$. É esse freio que oferece uma garantia de melhores condições de vida para as classes economicamente atrasadas. Existem três formas de justificar este freio para o autor.

Primeiro essa liberdade é justificada como uma necessidade histórica, como se acreditava no marxismo à luz do materialismo histórico ${ }^{273}$. Segundo: o freio deriva a sua

270 “[...] ele é considerado livre socialmente no aspecto formal, muito embora sua liberdade formal possa não ter nenhum conteúdo verdadeiro. Pois a liberdade formal para comprar não significa realmente, poder de compra. Significa apenas, em seu sentido social, que a sociedade permite a alguém, no âmbito de suas possibilidades e oportunidades determinadas por usa posição no curso da competição com os demais, a adotar qualquer método que o capacite a adquirir aquela mercadoria". (ASSADR, 2012, p. 245)

271 "Eis a razão pela qual ela não se preocupa em proporcionar a uma pessoa a capacidade ou garantir à mesma a liberdade essencial. Simplesmente deixa isso para as oportunidades e possibilidades que alguém venha a conseguir, considerando suficiente proporcionar a liberdade formal que permita à pessoa desempenhar diferentes tipos de atividades econômicas para alcançar seus objetivos, e rejeitar qualquer autoridade social que exerça pressão ou coerção em qualquer campo da vida". (ASSADR, 2012, p246)

272 "Por isso a liberdade que um empresário tem de empregar ou dispensar um trabalhador e a liberdade que os ricos possuem de aplicar sua riqueza como convir a seus interesses, como foi estabelecido pelo principio da liberdade forma, e a impossibilidade de se aplicar o principio da garantia do trabalho aos indivíduos ou a garantia de sustento para os que não possam trabalhar, por estarem inválidos. Pois o fornecimento de tais garantias não é possível sem limitar as liberdades que os ricos e empresários possuam. Assim tanto os empresários como os ricos são autorizados a agir como desejam, e a estes se dá a liberdade formal, de maneira que se torna impossível fornecer garantias ao trabalho com o sustento, ou essas garantias são fornecidas e os empresários e as elites são impedidos de agir de acordo com sua própria vontade, o que significaria a violação do princípio da liberdade formal, que defende a necessidade de permitir a todos a liberdade de agir como queriam, no campo econômico". (ASSADR, 2012, p.248)

273 " [...] quando o socialismo marxista deu fim à liberdade, deu fim à liberdade formal estabelecendo um sistema ditatorial, exercendo autoridade absoluta no país. O socialismo 
justificação da crença em uma autoridade superior, que possui o direito de organizar toda a humanidade, como a religião ${ }^{274}$. Terceiro: a limitação e freio surgem como resultado de uma consciência que ordena ao homem valores morais e limites definidos. Porém, o capitalismo não acredita nem no materialismo histórico, nem apresenta qualquer relação com a religião ou a consciência.

Com base nesta visão, Assadr argumenta que há apenas dois caminhos abertos diante do capitalismo: ou as pessoas ricas são autorizadas a trabalhar como eles querem sendo fornecida a liberdade social formal, portanto, de sacrificar os interesses da população economicamente atrasada por causa deles; ou fornecer a garantia de vida melhor para as pessoas economicamente mais fracas, de modo que as pessoas ricas não estão autorizadas a agir de acordo com seu livre-arbítrio. Isto, no entanto, significaria violação do princípio da liberdade social formal.Assim, o autor conclui que o conceito de liberdade antes do capitalismo estava incompleto no que diz respeito à concepção de liberdade, Assadr argumenta que não é a liberdade social, mas a liberdade natural, que é a expressão real da dignidade humana ${ }^{275}$.

\subsubsection{A Base de um Novo Modelo}

A pesquisa realizada por Assadr, entre outros autores que citamos neste capítulo, permitiu a criação de um modelo islâmico. No capítulo III desta tese, descreveremos as leis que tornam possível um modelo baseado no Islã.

De fato, o modelo se apresenta como uma economia de mercado coordenada pelo Estado que muitos defenderão como um capitalismo islâmico e outros como uma economia islâmica. Não nos importando com sua nomenclatura, sabemos que esse

afirmava que havia compensado a liberdade formal proporcionando a liberdade essencial, ou seja, proporcionando Às classes trabalhadoras as garantias de trabalho e de sustento". (ASSADR, 2012, p.248)

274 "Essa incompatibilidade polarizada entre a liberdade formal e a essencial, ou entre a forma e a essência, não se resolveu senão no Islam, que acredita que a sociedade necessita de ambas as formas de liberdade. Por conseguinte, o Islã proporcionou à sociedade a liberdade essencial assegurando um grau razoável garantia a todos os indivíduos da sociedade, uma vida honrada e os requisitos necessários para isso, reconhecendo a liberdade dentro dos limites dessa garantia". (ASSADR, 2012, p.249)

275 "É possível declarar a esse respeito que a liberdade é uma parte da identidade do homem e que se ele é privado dela, perde sua dignidade e sem caráter humano, perde a distinção dos animais. Essa expressão superficial não se aplica a uma análise científica do valor da liberdade e só pode atrair a alguém que seja afeito a jogar com as palavras". (ASSADR, 2012, p.249) 
modelo de economia de mercado baseada na religião islâmica existe e se expande como uma brecha dentro do capitalismo tradicional.

Procuraremos neste terceiro capítulo apresentar as ideias e as discussões para o desenvolvimento das relações internacionais entre os modelos. Esse relacionamento parece existir sob uma crítica feroz, como mostrado pelos pensadores da economia islâmica. Mas o pragmatismo dos líderes e mesmo o interesse de manutenção da ordem permite continuar o desenvolvimento. 


\section{CAPÍTULO III}

"A única maneira de liquidar o dragão é cortar-lhe a cabeça, aparar-lhe as unhas não serve de nada."

José Saramago

\section{RELAÇÕES ECONÔMICAS INTERNACIONAIS NO ISLÃ}

\subsection{Introdução}

O termo economia convencional é muito utilizado para determinar os modelos que não seriam islâmicos, ou seja, capitalismo e socialismo na atualidade. Iremos aqui também utilizar este termo, apenas com o intuito de diferenciar os modelos e fazer nosso debate. Como atualmente não temos mais estados socialistas no estrito sentido do termo, quando abordarmos modelo convencional estaremos falando do capitalismo, com suas diversas faces.

A economia islâmica não se apresenta tão diferente da convencional. Tanto a convencional quanto a islâmica buscam a melhor alocação e distribuição dos recursos escassos. Uma das contribuições mais importantes da economia islâmica é a adoção de uma abordagem dinâmica multidisciplinar.

Os economistas islâmicos não focaram primeiramente sua atenção nas variáveis econômicas, eles repensavam o bem-estar dos homens como produto final da interação em um longo período de tempo entre os fatores econômicos, morais, sociais, políticos, demográficos e históricos de tal forma de que nenhum deles é capaz de fazer uma contribuição valiosa sem o suporte de outros. A justiça aqui ocupa o principal ponto em toda esta estrutura.

Dos primeiros economistas islâmicos temos Ibn Khaldun ${ }^{276}$, que centra sua análise no ser humano. Para o autor, a ascensão e queda de dinastias ou civilizações estão intimamente ligadas ao bem-estar e à miséria da população. O bem-estar da população, por sua vez, não é dependente apenas das variáveis econômicas, como a economia

\footnotetext{
${ }^{276}$ Sua breve biografia é abordada no capítulo um da tese e explica seu papel na história do desenvolvimento do pensamento econômico islâmico, sendo considerado o pai da moderna economia. Em sua pesquisa discute sobre a assabiyya, ou seja, a coesão social, que para ele torna algumas civilizações grandes e outras não. Para o autor algumas forças são cíclicas.
} 
convencional tem enfatizado até recentemente, mas também está intimamente relacionado a fatores morais, psicológicos, sociais, econômicos, políticos, demográficos e históricos.

Podemos citar outros autores que procuraram debater a economia islâmica como Abu Yusuf, al-Mawardi, Ibn Hazm, al-Tusi, al-Ghazali, al-Dismashqi, Ibn-Hushd, IbnTaymiyyah, Ibn al-Ukhwwwah, Ibn al-Qayyim, al-Shatibi, al-Maqrizi, al-Dawwani e Shah Waliyullah. Estes fizeram grandes contribuições para a teoria islâmica.

A base de sua economia difere da convencional mais por não estar alinhada a nenhum ponto de vista materialista, mas ser baseada em um ponto de vista religioso, buscando o bem-estar de todos os indivíduos. A questão da propriedade privada, para os muçulmanos, é uma forma de proteção e garantia do bem-estar do homem. O Islã também reconhece o mercado como forma de alocação eficiente dos recursos, porém não acredita que a competição seja suficiente para garantir o interesse social. Por isso o Islã defende um modelo econômico diferente, que possa promover a irmandade e a justiça econômica, através da integração dos valores morais no sistema, como veremos nesta parte da tese.

Neste capítulo, abordaremos as relações entre os modelos, inserindo as entrevistas coletadas para a pesquisa. Procuramos repensar os valores islâmicos frente ao sistema internacional a partir do discurso dos pesquisadores da Universidade de Qom.

\subsection{A Ética Islâmica e seus Princípios}

O mercado não é a única instituição onde as pessoas interagem na sociedade; os seres humanos também interagem em suas famílias, na sociedade e no governo, e as interações nessas instituições estão intimamente relacionadas. Para o Islã, a atuação nestas esferas foca apenas o interesse próprio, como no capitalismo, no qual não há regras morais claras, não sendo benéfico para os seres humanos. Instituições como a família irão se desintegrar, o governo poderá apresentar larga corrupção, a sociedade poderá atuar de forma indiferente aos problemas, entre outros fatores.

O sacrificio de si próprio representa um papel importante no sistema social islâmico, já que, na visão islâmica, o ser humano é a parte mais importante do sistema, não só o mercado, mas a família, a sociedade e o governo compreendem o sistema, focando em si a atuação do homem. O trabalho conjunto e o sacrifício pessoal desempenharão um papel para a solução dos problemas econômicos na visão de Assadr. 
Podemos dizer que há um código de ética islâmica, o qual é indicado pelos líderes religiosos como uma guia para se fazer negócios. Esse código surge da conduta do Profeta e para os muçulmanos é necessário que se comportem islamicamente em seus negócios, já que Deus é testemunha de suas transações ${ }^{277}$.

Nas entrevistas realizadas no Irã, quando questionado sobre o relacionamento entre os modelos, o Professor Tawakali reconheceu que há diferenças entre as culturas e os modelos:

\begin{abstract}
"Na verdade, há alguns conflitos entre essas duas culturas, diferentes culturas. Sim. Mas, ao nível das instituições e entre as diferentes instituições, não é tão dificil a ponto de ser intransponivel, porque existem algumas regras na cultura islâmica, talvez ... Reciprocidade ... Essa reciprocidade de modo que o banco islâmico pode tomar estes regras para a interação negociaveis."
\end{abstract}

Dois dos princípios mais importantes abordados são a honestidade e a veracidade, as quais são consideradas qualidades que todos os muçulmanos devem desenvolver e praticar em si mesmos. Há diversos hadiths e versos do Corão que enfatizam a questão da honestidade ${ }^{278}$. A questão de se manter a palavra é considerada uma garantia do paraíso para os muçulmanos. Falar a verdade, manter suas promessas, evitar a imoralidade, refrear-se da injustiça, todos esses pontos são enfatizados nos hadiths.

Em entrevista, foi perceptível a rejeição ao sistema capitalista e o Professor Moshirzadeh aponta especificamente para a questão do porque não se aceitar este modelo:

"O sistema moderno ensina que não há papel para Deus, para crença e o divino. $\{\ldots\}$ Deus pelos livros e a profecia, certo e no direito através do conhecimento $\{\ldots\}$ para colocar o papel de Deus. E, mencionei brevemente a afirmação, mas estou pronto para provar-los, defendê-los, se necessário. O humanismo, eles afirmam que devemos respeitar o humano, que o ser humano deve ter acesso, mas é claro, eles querem dizer a $\{\ldots\}$ pessoa que gerencia a dominação da riqueza e da pobreza e estão indo para monopolizar o seu pensamento. Se você comprar essa premissa da democracia liberal. Eu afirmo que todos eles estão divagando pois não há verdade nelas, e eu sou capaz de provar que não há verdade nelas. Não há nenhum valor para os seres humanos, durante trinta e um anos no Vietnã mataram a 3 milhões"

277 "Ó fiéis, não consumais reciprocamente os vossos bens, por vaidades, realizai comércio de mútuo consentimento e não cometais suicídio, porque Deus é Misericordioso para convosco." (Corão 4:29) "Se agraciarmos os homens com a Nossa misericórdia, depois de os haver açoitado o infortúnio, ainda assim desmentirão os Nossos versículos. Dize: Deus é Rápido em planejar. Sabei que os Nosso mensageiros registram tudo quando tramais." (Corão 10:61)

${ }^{278}$ Sahih al Bukhari,Hadith n. 8:116 
O amor ao dinheiro e a grande lucratividade são debatidos pelos estudiosos, sendo esses os grandes lemas para o capitalismo. Mas no Islã, o homem não deve se apegar aos bens materiais e a suas atividades nesse mundo, já que aqui a vida é passageira. O homem deve amar mais a Deus do que qualquer outra coisa, pois sua ligação com a terra é apenas uma fase de sua vida ${ }^{279}$. Por isso é que os muçulmanos devem procurar primeiramente negociar com os próprios muçulmanos e depois com os não-muçulmanos.

Outro ponto importante é a forma de condução da vida, deve-se ser humilde na forma com que conduzimos a vida, não expondo bens, não sendo extravagantes e exibicionistas, mostrando boa vontade nas transações ${ }^{280}$ pois a economia convencional considera comportamento, gostos e preferências de cada tal como consta, mas a economia islâmica não. Este ponto foi muito importante na reforma realizada pelo Islã no sistema social, buscando um soerguimento moral da sociedade, através da mudança do comportamento humano, para que assim sejam atingidas as necessidades grupais do sistema.

Para o Islã, o homem deve usar o filtro moral ao entrar no mercado, esse filtro deve fazer com que se torne um consumidor conspícuo, deixando as extravagâncias e a má utilização dos recursos do mercado. Esse filtro deve levar o homem a fazer ótimo uso dos recursos na economia, os quais são necessários para satisfazer suas necessidades materiais, assim como as espirituais. Esse filtro moral tem a finalidade de reduzir a concentração de riqueza em poucas mãos, aumentando a poupança apenas para promover os investimentos e o emprego ${ }^{281}$.

A diferença aqui é que o sistema islâmico procura preencher as necessidades espirituais, como forma de impulsionar o sacrifício, envolvendo assim os seres humanos, para que estes procurem a ênfase no grupo. Para o Islã, o homem não pode servir apenas aos seus próprios interesses neste mundo, sendo egoísta, desonesto, negligente de suas obrigações com respeito à família, aos outros seres humanos, aos animais e ao meio

279 "Dize-lhes: Se vossos pais, vossos filhos, vossos irmãos, vossas esposas, vossa tribo, os bens que tenhais adquirido, o comércio, cuja estagnação temeis, e as casas nas quais residis, são-vos mais queridos do que Deus e Seu Mensageiro, bem como a luta por Sua causa, aguardai, até que Deus venha cumprir os Seus desígnios. Sabei que Ele não ilumina os depravados." (Corão 9:24) ${ }^{280}$ Como forma de limitar as transações, o Irai proíbe a importação de luxo. Disponível em $<$ http://iranprimer.usip.org/blog/2012/nov/09/list-iran-bans-luxury-imports $>$. Acesso em: 20out.2014.

${ }_{281}$ Islamic Trade, Import-Export Law and Regulations Handbook, 2012, p.22. 
ambiente. No entanto, não poderá servir a seus interesses na vida após morte ${ }^{282}$. A questão da vida após a morte funciona como um mecanismo de motivação para que o ser humano se sacrifique aqui, algo que não se possui na economia convencional.

\subsection{A Lei Econômica no Islã e sua Regulamentação}

Assadr procurou apresentar um modelo econômico para os muçulmanos, afastando-se assim do modelo capitalista e comunista naquele período. Seu modelo diferencia as necessidades básicas e as luxúrias, trazendo regras rígidas, considerando a questão dos escassos recursos na natureza. Para o autor, a implementação do Islã poderia eliminar paulatinamente o controle da elite, sendo que, aos poucos, iria se estabelecer a igualdade entre as classes, sempre sendo incentivado o trabalho árduo.

O pensamento islâmico acabou por desenvolver um sistema que procura eliminar a exploração através de regras rígidas e controle por parte do Estado. A Lei Islâmica define regras para regular as companhias, procurando prevenir o abuso e corrupção. $\mathrm{O}$ Islã proíbe o monopólio, proíbe a acumulação de riqueza, eliminando as leis de direitos naturais e patente que podem contribuir para potentes monopólios. O Islã também procura proteger a propriedade privada da pessoa e empresa, havendo algumas restrições.

Para o Islã, quando o rico sempre permanece rico e o pobre sempre pobre há opressão. Recentemente, este tema tem sido mais debatido por economistas e tem ganhado maior atenção, sendo que para o Islã a riba é uma das causas - talvez a principal - que leva uma grande massa à pobreza, levando também uma elite global, mais centralizada talvez no Ocidente, mas que se encontra por todo o mundo hoje a sugar constantemente a riqueza da humanidade. Esse sistema acaba por escravizar a humanidade de uma forma mais sofisticada, já que os sistemas político, legislativo, judicial etc são todos controlados por esse grupo opressor. Sua função é preservar o sistema econômico.

A visão comum sobre a riba entre os juristas da lei islâmica é que ela é proibida. A riba é vista como um ganho injustificado com o qual a pessoa poderia receber uma vantagem monetária em uma transação de negócios sem dar um retorno justo, sem

\footnotetext{
${ }^{282}$ Neste ponto há diferenças entre alguns autores, já que Assadr oferece ênfase na crença de que o homem precisa mudar, mas isso não é compartilhado por outros autores do período contemporâneo.
} 
trabalho. Tecnicamente a riba é vista como um prêmio que é pago pelo tomador de empréstimo ao emprestador, junto com o montante principal como uma condição do empréstimo. Nesse sentido, a riba é um pecado pela lei islâmica. Essas regras funcionam como princípios que os juristas têm derivado do Corão e da Sunna. Essas regras são amplamente aceitas como relevantes para a vida econômica e expressam o espírito islâmico que tem guiado o homem durante os séculos.

O Corão adverte que os muçulmanos devem demonstrar consistência na fé, mostrando-a em palavras, mas também em ações ${ }^{283}$. Com essa ideia básica, formou-se a lei islâmica, que determina a relação entre intenção e ato, e entre reinvindicações e ações. A primeira máxima legal é: “A base de cada ordem é a intenção, disso um julgamento baseado em uma ordem deveria seguir a intenção e o propósito desta ordem." 284

A regra inserida nesta máxima legal tem sido aplicada pelos primeiros juristas mais em atos de rituais, porém pode ser igualmente aplicada em outras esferas de atividades. A responsabilidade da pessoa que encontra a mercadoria de alguém e a devolve ao proprietário, será posicionada como administrador e não se exigirá identificar o dono em caso de que esta propriedade seja destruída. Enquanto o objeto está em sua posse, mas se tomar posse como um dono deverá ser tratado como tal ${ }^{285}$. Esses exemplos citados são expostos na lei como base para fundamentação do relacionamento comercial.

Algumas características devem ser levadas em conta nos negócios:

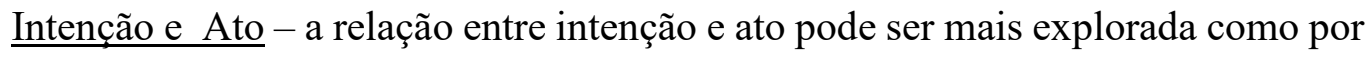
exemplo, quando um homem faz um ganho, este pode ser para satisfação de impulsos egoístas, pode ser para consumo pessoal, para sua sobrevivência e manutenção da família, bem como para gastos com causas nobres. Em todos os casos o ato é o mesmo, porém a intenção/objeto é diferente. Citemos aqui também o exemplo da plantação de uva, que pode ser para o consumo da fruta em si, ou para a produção de vinho. O que deve se considerar é a intenção, esta determina a legalidade ou ilegalidade do ato de um individuo.

\footnotetext{
283 "A resposta dos fiéis, ao serem convocados ante Deus e Seu Mensageiro, para que julguem entre eles, será: Escutamos e obedecemos! E serão venturosos." (Corão 24:51); "Volta o teu rosto para a religião monoteísta. É a obra de Deus, sob cuja qualidade inata Deus criou a humanidade. A criação feita por Deus é imutável . Esta é a verdadeira religião; porém, a maioria dos humanos a ignora." (Corão 30:30)"Ó Senhor nosso, redobra-lhes o castigo e amaldiçoa-os reiteradamente!'( Corão 33:70)

${ }^{284}$ Islamic Trade, Export-Import Laws and Regulations Handbook. Volume 1, Strategic Informations and Laws for Selected Countries. Washington DC, USA: 2012. p.40.

${ }^{285}$ Islamic Trade, Import-Export Law and Regulations Handbook, 2012, p.40.
} 
O Professor Hadawinia explica isso em sua entrevista, buscando mostrar que o sistema se adapta, ou seja, não é pragmático:

\begin{abstract}
"Então, nesse ponto, não haja nenhum problema, isso é possível. Mas, em nossa opinião, porque, você sabe, é algo que vem desde a origem dos países em que são contra as sharias islâmicas. Isso não significa que nós não exportamos nossos uvas para a França para fazer vinho. Se sabemos que o vinho é criado ... vamos enviá-los para uma fábrica de vinho, por isso não é nossa escolha para fazer isso. Este é o ponto mais importante ... mas em geral ... no caso de um negócio internacional, ou em alguns casos especiais que, tem alguma barreira cultural, barreira cultural, ah ... Mesmo que haja um negócio entre dois muçulmanos, eles têm ... eles deveriam seguir os princípios islâmicos do negócio, comércio, mas, então temos essa relação com os países não islâmicos, que nós podemos ter mais liberdade com o não-islamicos."
\end{abstract}

O Islã apresenta opções para análise de seus casos, dando espaço para a atuação do Estado e certa liberdade do indivíduo.

Dúvida e certeza: a regra básica que resolve a questão do conflito entre a dúvida e a certeza está contida no princípio: "Uma crença no valor de condenação não pode desaparecer por uma dúvida”. ${ }^{286}$ Essa crença é baseada em versos corânicos que descartam os efeitos da dúvida que desorientam uma posição original. A questão é providenciar um guia no qual reserva, julgamento pessoal e evidência subjetiva são invocados. Essa regra tem grande significância no evento de controvérsia a respeito de direitos e obrigações no contencioso entre partes na falta de prova por cada lado da demanda.

O benefício da dúvida decorrente de uma posição controversa nunca pode ir para uma pessoa a quem o ônus da prova recai. Assim, a posição de uma pessoa em débito, mesmo após sua morte, não será afetada por dúvida quanto a uma provável quitação de dívida. Similarmente, uma requisição de pagamento de um débito não será rejeitada com base na presunção do contrário. Um contrato entre duas partes será tratado como obrigatório mesmo que haja razões para dúvidas. No caso de uma firma declarar um montante particular como receita durante o ano, isto deve ser aceito pelo fisco na falta de evidência do contrário.

Eliminação do detrimento: a regra mais importante da lei islâmica que regula todo o sistema econômico e financeiro "proíbe a imposição do dano e desencoraja a

\footnotetext{
${ }^{286}$ Islamic Trade, Export-Import Laws and Regulations Handbook, 2012. p.42.
} 
retaliação". Esta regra básica é tratada como um pilar da lei islâmica e forma a base das leis de opções, restrição, devolução de mercadorias com defeitos, preempção ${ }^{287}$, retribuição, hudud, compensação e indenização etc. Esta regra também permite a indivíduos agirem unilateralmente para protegerem a si mesmos e outros do dano.

É necessário que o estado legisle e gerencie de forma que proteja as pessoas de fontes que possam causar dano. Por exemplo, com a intenção de proteger os seres humanos, permite que o governo mantenha uma lista negra dos comerciantes que agem de forma ilegal e estão ligados a atividades antissociais, tais como contrabando e adulteração ${ }^{288}$. Pode-se também tomar ações sobre pessoas ou empresas que dão suporte a práticas contra a lei.

De acordo com a lei islâmica, negociar itens contra a lei e adquirir ganhos fora das normas islâmicas pode gerar empregos a um grande número de pessoas e trazer impostos substanciais ao governo, porém devem ser removidos por parte do governo ${ }^{289}$.

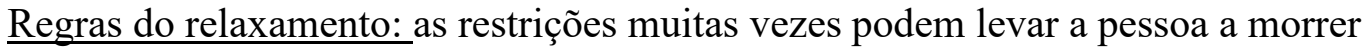
de fome por conta de um ganho que é contra a lei ou não está viável de forma permissível. Nessas circunstâncias, a lei islâmica permite o que é contra a lei, pois a lei é para a própria proteção do muçulmano e pode ser aliviada e promover um relaxamento de si mesma, com o intuito de proteger os fiéis ${ }^{290}$.

Sobre a área econômica Hasanuzzaman (2007, p.23-24) cita o seguinte exemplo:

"É proibida a venda de frutas na árvore antes de chegarem à maturidade. Também é proibida a venda de grãos pela mesma quantidade e espécie para entrega futura. Além disso, a quantidade vendida deveria ser determinável e não conjectural. O hadith relaxa esse princípio para a extensão de 5 wasqs no caso de tâmara e uva, para aqueles cultivadores que precisam deles; porém eles devem esperar muito tempo para sua própria produção. Tais cultivadores são permitidos a vender conjecturalmente a quantidade fresca que esperam produzir por uma quantidade de produtos secos disponíveis prontamente [...] Similarmente, um contrato para vender uma commoditie que uma pessoa não possui no momento é contra a lei. Bay' Salam, que tecnicamente significa pronto pagamento por uma commoditie que o vendedor não possui, é permitido no caso de produtores que precisam de financiamento para as entradas."

\footnotetext{
${ }^{287}$ A compra de mercadorias ou ações, por uma pessoa ou grupo, antes da oportunidade ser oferecida a outros.

${ }^{288}$ HASANUZZAMAN, S. M. The Economic Relevance of Sharia Maxims. 2007, p.14.

${ }^{289}$ Islamic Trade, Export-Import Laws and Regulations Handbook, 2012, p. 16.

${ }^{290}$ Idem, p. 23.
} 
Para garantir a produtividade do sistema não é dificultado para o cultivador vender sua produção esperada contra pagamento antecipado. No contrato devem ser especificadas a contratação e comissão do produto que ainda não existe.

Dificuldades podem ser enfrentadas devido à compulsão, miséria, problemas físicos, ignorância ou doença, dentre outros fatores, o que permite relaxar as regras para garantir o atendimento das necessidades dos fiéis.

Dar e tomar: da regra de dar e tomar no Islã, o princípio que a governa é: “O que é haram para tomar é haram para dar", ou "O que é haram fazer também é haram para demandar”. Essa regra é relevante não somente nas transações financeiras, gratificações ilegais etc, mas também por gratificações não financeiras como adotar profissões que são rejeitadas na lei islâmica. Essas regras de fato são claras para os indivíduos, porém requerem alguma elaboração referente às ações e políticas para o governo. O Estado tem o papel de estabelecer instituições para conduzir a vida dos muçulmanos, cumprir as normas religiosas e manter os valores islâmicos agindo na vida do homem.

Regras sobre beneficio/responsabilidade: a relação entre o direito de aproveitar um benefício de uma propriedade e a responsabilidade de incorrer em perda devido a posse ser ordenada por um número de regras que carregam grande significância em transações de natureza comercial.

Neste caso, diversas ilustrações são utilizadas para exemplificar a questão da responsabilidade do governo com a população. Por exemplo: uma pessoa cava uma fossa em suas terras, o animal de um vizinho adentra estas terras e cai neste fosso e falece, o dono das terras não precisa indenizar o dono no animal, já que ele tinha o direito de fazer a fossa em suas terras. Similarmente se presume que o governo islâmico deve fornecer os melhores serviços públicos para seus cidadãos e caso não ocorra isso, o governo não deverá ser responsável por compensar uma perda.

Há casos em que o governo deverá indenizar, sendo que é necessário comprovar, por exemplo, a usurpação dos direitos, o crime, a negligência entre outros. A máxima legal discutida é "se uma pessoa obtém os benefícios de algo, caso haja uma perda deverá se responsabilizar por isso." 


\subsection{Contratos na Lei Comercial Islâmica ${ }^{291}$}

A lei comercial islâmica constitui uma importante área que lida com temas como contratos e os efeitos legais que estes possam apresentar. Na lei islâmica, o contrato é considerado uma disciplina legal complexa, tanto em sua fundação jurisprudencial quanto em sua função legal. Este cobre uma variedade de tipos de negociações e transações para atender às necessidades da sociedade. Sem dúvida, temas das transações comerciais, tais como a devoção ('ibadat), estão cercados de variações, devido a mudanças das circunstâncias e situações tanto do objeto quanto do tema das transações.

$\mathrm{Na}$ evolução da lei dos contratos, a lei islâmica devotada ao tema, assim como outros sistemas legais, inicia com os versos corânicos, os quais contêm os rudimentos de muitos tipos de contratos assim como tópicos legais contratuais de importância geral. Além do mais, as tradições suplementam a base corânica e os juristas de todas as escolas islâmicas desenvolveram princípios para a base de contratos. No Corão há, pelo menos, quarenta versos e doze tipos de contratos, portanto é um tema de grande preocupação da lei islâmica e seus pensadores.

Há alguns versos no Corão os quais revelam os contratos comerciais, tais como venda e aluguel, cobrança para garantia pessoal, dentre outros tipos. A ideia de se fazer um contrato é para satisfazer ambas as partes em um acordo e é assim não apenas no sistema legal islâmico, mas também em outros sistemas legais. De fato, no Islã isso é colocado como a melhor forma de refletir a intenção e satisfazer as necessidades de ambas as partes.

A lei islâmica nunca desenvolveu uma teoria geral dos contratos. Em vez disso, a maioria dos juristas muçulmanos focou no contrato de venda que é utilizado como modelo para todos os tipos de contratos. No entanto, o Código Civil Islâmico ${ }^{292}$ oferece uma definição precisa para o contrato. Para um contrato ser válido na lei islâmica é necessário preencher certas condições ${ }^{293}$. No entanto, a lei islâmica é distinta de outros sistemas

\footnotetext{
${ }^{291}$ Nos anexos colocamos os modelos de contrato na atualidade, com intuito de apresentar as diferenças para os nossos contratos. Estes exemplificam o funcionamento do sistema islâmicos, em alguns pontos diferentes dos contratos do modelo capitalista e em outros pontos similar.

${ }^{292}$ Não temos apenas um código civil, teremos diversos códigos, sendo estes similares, baseado na lei islâmica. No caso dos contratos é informado que a base para este é a mesma.

${ }^{293}$ Um contrato válido deve ser basear em seis elementos, o nome de quem oferece o produto e quem está aceitando, o oferecimento e aceitação devem estar bem descritos, o assunto do contrato e a consideração sobre ele. As partes do contrato devem ser legalmente competentes.
} 
legais pois insiste na seção do contrato (majilis al-'aqd), já que ambos - quem oferece e quem aceita - devem estar juntos, conectados em uma única seção, sem nenhum gap de tempo ou local para consumar o contrato. A seção pode ocorrer em qualquer local, onde as partes se encontram para fechar o acordo e esta seção cria uma unidade essencial de tempo e lugar para a declaração de ambos de intenção e consentimento ${ }^{294}$.

A lei islâmica insiste que nos contratos as partes devem estar presentes já que cada um deve ouvir as declarações do outro, que devem ser submetidas no contrato e deve ser dada relevância legal. As comunicações dos contratos realizados por representantes ou pelos meios de comunicação moderna como telefone, telex, fax, e-mail, carta, todos são igualmente válidos realizados em uma única seção de contrato.

Sobre o assunto do contrato, tanto sobre o item e sobre a consideração, a lei islâmica destaca temas como, legalidade, existência, entregabilidade e precisão. A lei declara que o objeto deve ser algo permitido, que deve ter valor legal, seu tema (mahall) e causa (sabad) devem também estar dentro da lei. O objeto deve ser de posse legal do seu vendedor e deve existir no período deste contrato, deve ser determinado de forma precisa, indicando quantidade e valor.

A lei islâmica não restringe a um preço monetário, mas este deve ser na forma de outra mercadoria. A proibição islâmica sobre a incerteza requer que deve ser um preço determinado na hora do contrato e não pode ser fixado mais tarde, com referência ao preço do mercado e nem pode ser deixado para uma terceira parte determinar este preço. No contrato de câmbio (sarf), a regra da riba deve ser acrescentada para que este seja válido. A capacidade das partes para um contrato é extremamente importante para o Islã, já que ninguém pela legislação islâmica pode concluir uma transação legal sem atingir a maturidade física ${ }^{295}$ e intelectual, sendo homem ou mulher.

O contrato, da perspectiva legal islâmica, é conceitualmente dividido em duas categorias: unilateral e bilateral. Enquanto o primeiro é livre em caráter e não precisa do consentimento do recipiente, o último é mais cercado de regras e requer o consentimento de ambas as partes.

Há diversas classificações de contrato: 1 - Contrato de câmbio ('uqud almu'wadat); 2 - Contratos de seguridade ('uqud al tawthiqat); 3 - Contratos de custódia (wadi'ah); 4 - Contratos pertencendo à utilização de usufruto ('uqud al manfa'ah). Essas

\footnotetext{
${ }^{294}$ Islamic Trade, Export-Import Laws and Regulations Handbook, 2012, p.95.

${ }^{295}$ Idem, p.96.
} 
classificações não são exaustivas, pois no futuro muitos outros tipos de contratos com diferentes características poderão surgir com base na doutrina da permissibilidade, como discutida anteriormente, que poderá render todas as transações comerciais permitidas na falta de uma clara proibição. No entanto, a classificação acima parece ser muito compreensiva em cobrir todos os contratos encontrados na literatura islâmica.

Menção deve ser feita de que cada uma destas classificações consiste de diferentes transações, porém contribuem para o mesmo propósito, o de delinear um contrato. Embora os contratos nas transações da lei islâmica sejam classificados em diferentes categorias, parece que o contrato básico, em muitos casos e situações são os contratos de troca e a utilização do usufruto. O primeiro pressupõe a transferência de propriedade enquanto o último, a transferência de usufruto de uma propriedade de uma parte para outra.

Isto é claro na definição de ambos: venda e arrendamento na lei islâmica. Venda é definida como uma troca de uma mercadoria por outra: uma é chamada de objeto e a outra, preço, ou a transferência de uma propriedade por outra. Arrendamento ou ijarah é definido como a transferência de usufruto por consideração. Ambos constituem a principal atividade comercial porque os contratos remanescentes são amplamente dependentes destes dois tipos de contratos.

Portanto, a venda, considerada como o contrato por excelência e, também o arrendamento, foram expandidos na literatura sobre a lei islâmica. Estes dois contratos são a base para os outros contratos existirem. Em outras palavras, outros contratos são dependentes destes dois para existirem e/ou darem efeito. Ao contrário, estes dois contratos, relativamente falando, podem ser concluídos entre duas partes sem nenhum outro contrato como suporte. Por exemplo, hiwalah, kafalah e rahn não podem ficar por si sós, já que são dependentes do contrato de troca, seja de venda ou de arrendamento.

No caso de hiwalah, que significa transferência de débito de um devedor a outro, não pode ocorrer a menos que a relação de dívida tenha já sido estabelecida entre o cessionário, o cedente e o credor principal. O relacionamento de débito, por outro lado, pode ter lugar tanto de pagamento diferido ou no contrato de empréstimo direto. Consequentemente, é obvio que a hiwalah é originada de uma transação de venda (assim como de uma transação de empréstimo, kafalah, rahn etc).

Isto mostra, nomeadamente, que contratos são inter-relacionados para formar um sistema completo de mu'amalah para garantir a justiça assim como atender às 
necessidades das pessoas que variam de uma condição para outra. Portanto, é relevante concluir que a lei islâmica comercial consiste em muitos tipos diferentes de contratos para atender diferentes tipos de necessidades e circunstâncias. Em outras palavras, teoricamente, a lei islâmica comercial poderia ser capaz de satisfazer a necessidade de uma pessoa para comprar uma mercadoria a crédito, na necessidade de ter um garantidor contra uma terceira parte ou necessidade de ter um fundo para empreendimento dos negócios, ou na necessidade de ter o capital com antecedência para produzir, dentre outras situações.

\subsubsection{Classificação dos contratos}

Mesmo que os contratos na lei islâmica sejam classificados em diferentes categorias, o contrato base é o de venda, troca e utilização de usufruto, que abordaremos aqui. Iremos nesta tese abordar apenas os principais para demostrar as possibilidades de relação entre a economia islâmica e o capitalismo.

O contrato de troca (Mu'awadat) é o principal contrato pela lei comercial islâmica, principalmente como contrato de venda (bay), ${ }^{296}$ que falando de forma geral, envolve a troca de uma commoditie por outra commoditie ou uma commoditie por dinheiro, ou dinheiro por dinheiro. Curiosamente, riba que é proibido pela lei islâmica, se origina de dois tipos de troca, chamada de trocas desiguais de duas commodities usurárias e troca de dinheiro por dinheiro com diferentes quantidades ${ }^{297}$ ou sem transferência simultânea ou entrega imediata ${ }^{298}$ ou envolvendo ambas as possibilidades que tornam o contrato de troca de dinheiro por dinheiro nulo ou inválido baseados em ambas as modalidades da $r i b a^{299}$.

A primeira impressão que vem à nossa mente é que ambos os tipos de riba, enquanto similares em ambos os contratos de troca e câmbio, não são similares de alguma forma para a troca de mercadoria por dinheiro. Isto, entre outras razões, faz a negociação distinta e livre de qualquer elemento de juros. No entanto, contratos de câmbio que lidam com a troca e o câmbio são suscetíveis a elementos da riba e por esta razão, a lei islâmica tem relativamente estabelecido princípios rigorosos para garantir a legalidade destes contratos.

\footnotetext{
${ }^{296}$ Riba al-fadl ou riba al-buyu'

${ }^{297}$ Riba a-lfadl

${ }^{298}$ Riba al-nasi'ah ou riba al-duyun

${ }^{299}$ Al-fadl ou al-nasi'ah
} 
Contratos de troca de commoditie por dinheiro são relativamente mais expostos ao elemento do gharar, ou seja, ao azar e risco. Na terminologia legal islâmica, isto inclui a venda de mercadorias que não estão presentes nas mãos, ou a venda de uma mercadoria que ainda não é conhecida, ou a venda envolvendo o risco ou azar que não sabe se a commoditie existirá. Gharar pode tornar o contrato de comércio anulável. Diversas razões são dadas para a proibição do bay' al-gharar, algumas delas estão relacionadas à fraude desde que o montante de tal venda para obter a propriedade de outros por vender mercadorias não disponíveis e também o contrato que leva a disputas e desacordos entre as partes.

O contrato de utilização e usufruto, 'Uqud al-Manfa'at é o tipo de contrato dividido em duas categorias: transferência de usufruto por consideração e transferência de usufruto sem consideração, sendo o primeiro um contrato bilateral e o último não. $\mathrm{O}$ primeiro contrato é o Ijarah enquanto o último é conhecido por ' $a r i y a h^{300}$.

O contrato de ijarah é a contratação e locação de duas formas: propriedade corpórea toma as formas de propriedades imóveis, tal como território, ou mercadoria tais como móveis e animais. O segundo tipo de ijarah é um serviço pessoal. ${ }^{301}$ Os contratos de venda possuem dois pilares: ${ }^{302}$ o oferecimento e a aceitação. É argumentado que as "partes de um contrato" e o "assunto em questão", não são pilares, porém são os requisitos. A oferta e a aceitação mostra o consentimento e necessariamente inclui e implica a existência de duas partes e o assunto em questão.

Pela Escola da Lei Hanafi, a parte que primeiramente expressa seu desejo de fazer o contrato, fazendo a oferta (ijab), é a parte que expressa seu consentimento, o comprador (qabul). A oferta e a aceitação podem ser expressas verbalmente, por atos quando compramos itens com o preço na etiqueta em um supermercado, sem utilizar palavras, por gestos tais como na Bolsa e Valores onde ações são vendidas e compradas e através da escrita. Na atualidade, as vendas são feitas através de modernos meios de comunicação, como o fax e a internet e estes são considerados formas escritas para o Islã.

\footnotetext{
${ }^{300}$ Islamic Commercial and Trade Law Handbook, 2011 ,p.37

301 "O arrendador deve ser o dono absoluto da coisa ou o agente do proprietário natural ou guardião legal. $\mathrm{O}$ objeto a ser arrendado ou o montante devera ser completamente conhecido de ambas as partes. Em um contrato de contratação".

302 De acordo com a Escola da Lei Hanafi, mas a maioria argumentará que são três os pilares. (SALEEM, 2012, p.90)
} 
Tanto o vendedor como o comprador devem ser capazes legalmente, e a coisa a ser vendida deve estar bem definida, descrita neste contrato. O preço ou dinheiro (thaman) é um meio de troca.

Figura 2. Representação da venda

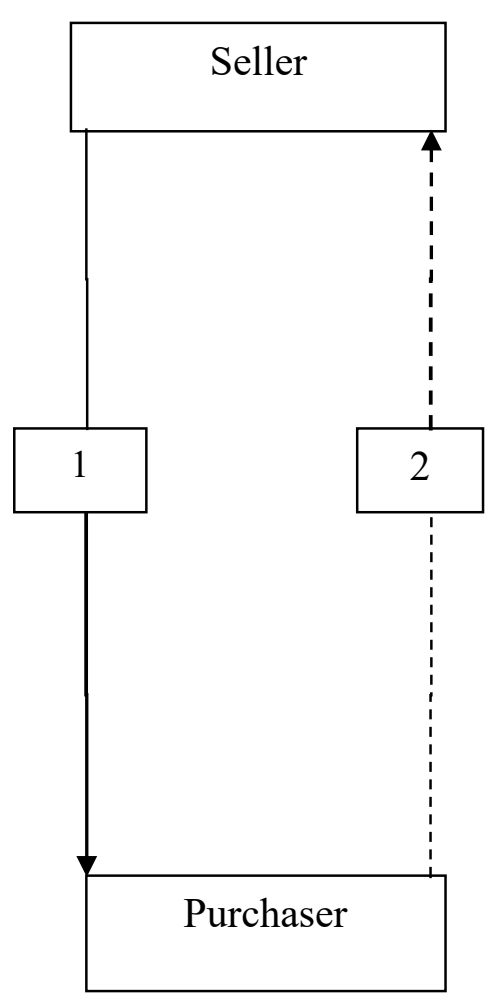

1- Sold item

2- The dotted line represents the price

Fonte: Saleem, M.Y. Islamic Commercial Law, 2013, p.11.

A venda por coerção acontece se uma pessoa é forçada a conduzir uma venda. Neste caso, a venda é considerada inválida. No entanto, de acordo com a escola Hanafi, a venda é dependente do consentimento tardio. Se o comprador dá seu consentimento tardio depois da coerção, a venda é considerada válida. A escola da lei Malik declara que esta venda não é vinculada e o vendedor, depois de remover a coerção, é livre para cancelar ou confirmar a venda como ele desejar. A escola Shafi e Hanbali vê esta forma de venda como inválida.

Uma venda por uma pessoa insana é acordada por todos os estudiosos. Se a venda é conduzida por uma pessoa considerada insana, é considerada inoperante por falta de capacidade. Por analogia, vendas conduzidas por bêbados ou drogados são consideradas inválidas. 
A venda para uma pessoa cega é acordada por muitos juristas que concordam que se a ampla descrição do objeto vendido é dada à pessoa cega, a venda é valida. No entanto, a escola Shafi considera inválida devido a pessoa cega não ter habilidade de realizar completamente a natureza da venda.

No caso da venda realizada por uma criança, há a questão se essa é capaz de discernir ou ser capaz de raciocínio, a venda é inválida de acordo com o consenso dos estudiosos. No entanto, se a criança é capaz de discernir e capaz de distinguir coisas, então há diferentes opiniões entre os estudiosos. A Escola Shafi define como inválida devido à incapacidade, porém as escolas Hanafi, Maleki e Hanbali dizem que a venda é suspensa aguardando a permissão do guardião.

A venda por uma pessoa sob medo ou compulsão significa que uma pessoa que está sob compulsão para vender sua propriedade terá sua venda nula, de acordo com a escola Hanbali, e ilegal, de acordo com a Hanafi.

No Islã, há discussão em todos os sentidos, abordando-se, por exemplo, a questão da venda feita por um serviçal. ${ }^{303}$ Isto significa que a pessoa concluiu o contrato referente a algo que não possui sem a autorização do dono. Nestes casos, Maleki e Hanafi consideram a venda válida, porém suspensa sob permissão do dono. Caso este dê o contrato, poderá ser válido.

A venda por uma pessoa sob interdição devido à doença ou insanidade da pessoa: esta é declarada incapaz. Se a interdição é devido à estupidez ou a tendência a esbanjar o dinheiro, então a venda é suspensa pela permissão do guardião. Se este permite, o contrato será confirmado, de outra forma é nulo. A venda realizada por alguém sob interdição devido à falência é suspensa pelos credores. Caso os credores permitam, a venda é confirmada. De outra forma a venda é nula.

No Islã, a venda realizada por pessoa muda, caso esta não possa fazer nenhum sinal legível, deve ser considerada inválida. Se puder fazer algum sinal, ou mesmo escrever, a venda é valida.

No caso de uma venda por correspondencia ou por um intermediário, que é comum devido à facilidade na comunicação, também é legislada pelo Islã. Se a mensagem chega e é respondida positivamente pelo remetente, a venda está correta. A definição do contrato deve ser mencionada nas regras jurisprudenciais e deverá ser no local e tempo

\footnotetext{
${ }^{303}$ Esse termo é utilizado nos próprios livros de lei comercial islâmica.
} 
da chegada da mensagem da primeira parte. Um contrato conduzido por um intermediário é válido entre os jurisprudentes. No entanto, se este intermediário excede sua designação e autoridade, então o contrato depende de uma permissão do autorizador. Se este libera, o contrato é firmado, de outra forma será nulo.

Outra venda também discutida é a nasi'ah, ou crédito adiado. Esta venda é chamada de kale' (credito adiado) e é anulada por consenso geral entre os juristas. Outra venda também levantada nas literaturas é a venda de coisas não existentes ou coisas quase não existentes. Exemplo deste tipo de venda é a mandamin (prole de machos), venda de malaqih (prole de fêmeas) e venda de habal al habalah ( prole da prole por vir). Os juristas concordam que todos estes tipos de venda são nulos.

Outro ponto que tem grande extensão de debate, incluindo na área financeira, é a questão da venda de coisas que não podem ser entregues, como peixes no mar e pássaros do céu. Este tipo de venda é nula em todas as escolas de jurisprudência. Aqui será nulo o contrato e isso rege partes da economia islâmica, como um princípio.

Uma venda em gharar ou em ignorância significa algo quenão pode ser definido ou especificado, sendo esta a razão pelo qual é proibida pelo Islã. A descrição do objeto a ser vendido é algo que deve ser feito de forma detalhada.

Outra questão abordada nos contratos é a venda de duas coisas em uma a venda de uma coisa específica por um ou dois preços diferentes. Por exemplo: "eu vendo este carro por R \$ 20.000,00 em dinheiro ou por R \$30.000,00 se você me pagar depois". Ou ainda, vender um ou dois objetos por um preço especifico. Alguns tipos de venda comuns no período pré-islâmico na Arábia foram proibidos pelo Islã.

De todos os modelos de venda no Islã, devemos dar destaque à murabaha, que literalmente significa uma venda onde é acordado o valor do lucro. Tecnicamente, é um contrato de venda no qual o vendedor declara seus custos e lucro. O vendedor transfere a propriedade que adquiriu por um certo preço ao comprador, com um incremento acordado no preço. $\mathrm{O}$ banco islâmico tem adotado este modelo como um modo de financiamento, que envolve uma requisição por parte do cliente ao banco para comprar certa mercadoria. O banco realiza esta atividade por um lucro, que é estipulado antes.

Outro contrato dentro do modelo islâmico que devemos exemplificar é o ijarah, que é um contrato de uso de uma propriedade de outra pessoa, no qual se especifica um retorno em consideração ao beneficio proposto a ser tomado. Em outras palavras, ijarah 
ou leasing, é a transferência de usufruto para a consideração que é arrendamento em caso de contratação de bens ou coisas e salário em caso de contratação de pessoas.

A ijarah é abordada no contexto das finanças islâmicas, já que instituições exportadoras podem achar prudente usar as finanças islâmicas no mercado islâmico, sendo que assim será mais fácil entrar nos negócios, evitando maiores riscos.

Neste esquema, o banco compra bens de capital ou propriedades e os arrenda sob parcelamento para usuários finais. Assim como no leasing convencional, deve haver uma opção para comprar as mercadorias no final do contrato da ijarah. O cliente seleciona os ativos a serem financiados, o banco compra do fornecedor e arrenda ao cliente pelo período acordado, refinanciando o ativo do cliente em uma venda e fecha o acordo de outro arrendamento pelo vendedor. Esta modalidade é permitida em algumas circunstâncias. O banco, sendo o dono do ativo, recebe um aluguel fixo ou variável, como acordado entre as partes. O montante do aluguel é frequentemente ligado à taxa libor.

Há dois tipos de contrato de ijarah, para o lease ou para contratação de serviços. O modelo para um empregado fornecer serviço para um empregador em retorno de um salário é o seguinte:

Figura 3 - Contratação de serviços

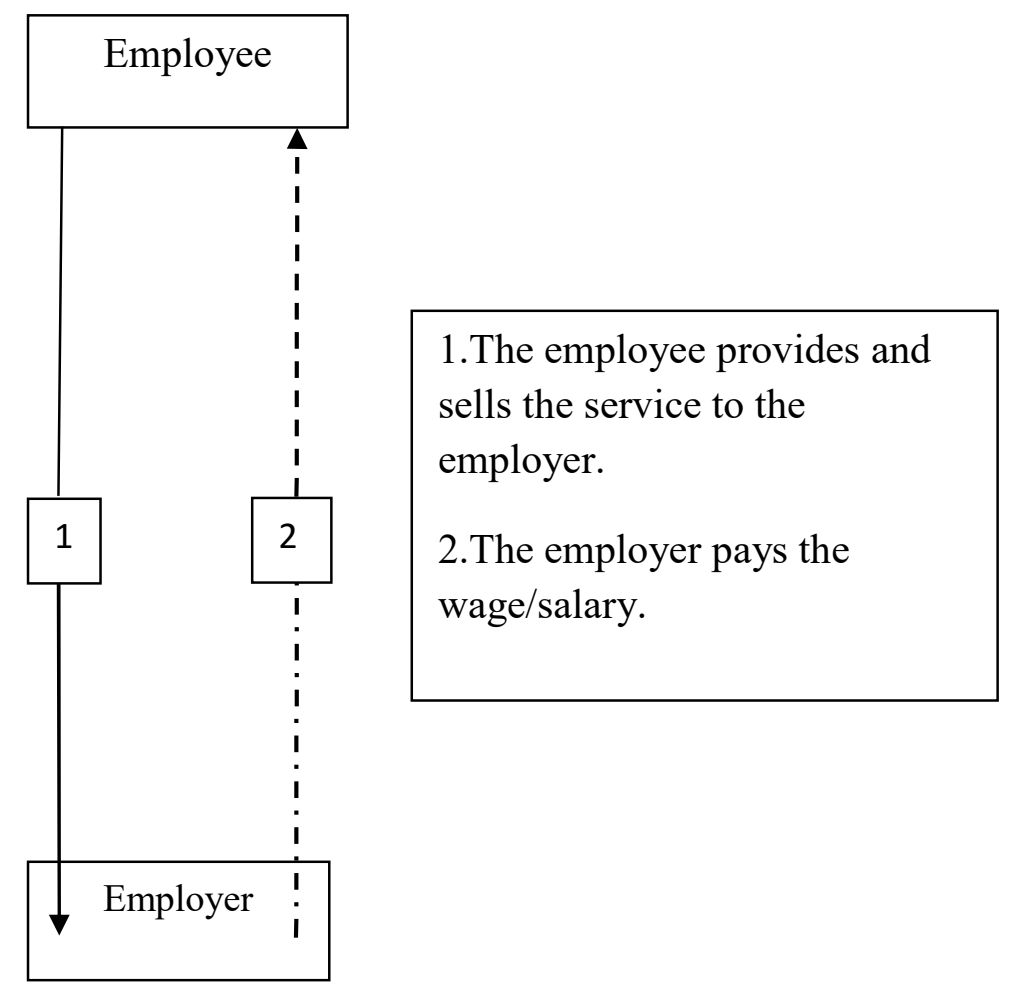

Fonte: SALEEM, M.Y. Islamic Commercial Law, 2013, p.54. 
O ijarah- wal-iIqtina é um contrato sob o qual um banco islâmico fornece equipamento, construção ou outros ativos para o cliente mediante um aluguel acordado junto a um compromisso unilateral - pelo banco ou cliente. Ao final do período de lease, a propriedade do ativo pode ser transferida ao locatário. O compromisso ou a promessa não se torna uma parte integral deste contrato para se fazer condicional. $\mathrm{O}$ arrendamento ou o preço de compra são fixadas de tais maneiras que o banco toma de volta sua soma principal juntamente com seu lucro sobre o período de arrendamento. Esses modelos de contratos serviram para a criação de toda uma estrutura financeira do sistema islâmico.

Figura 4: Contratação de serviços

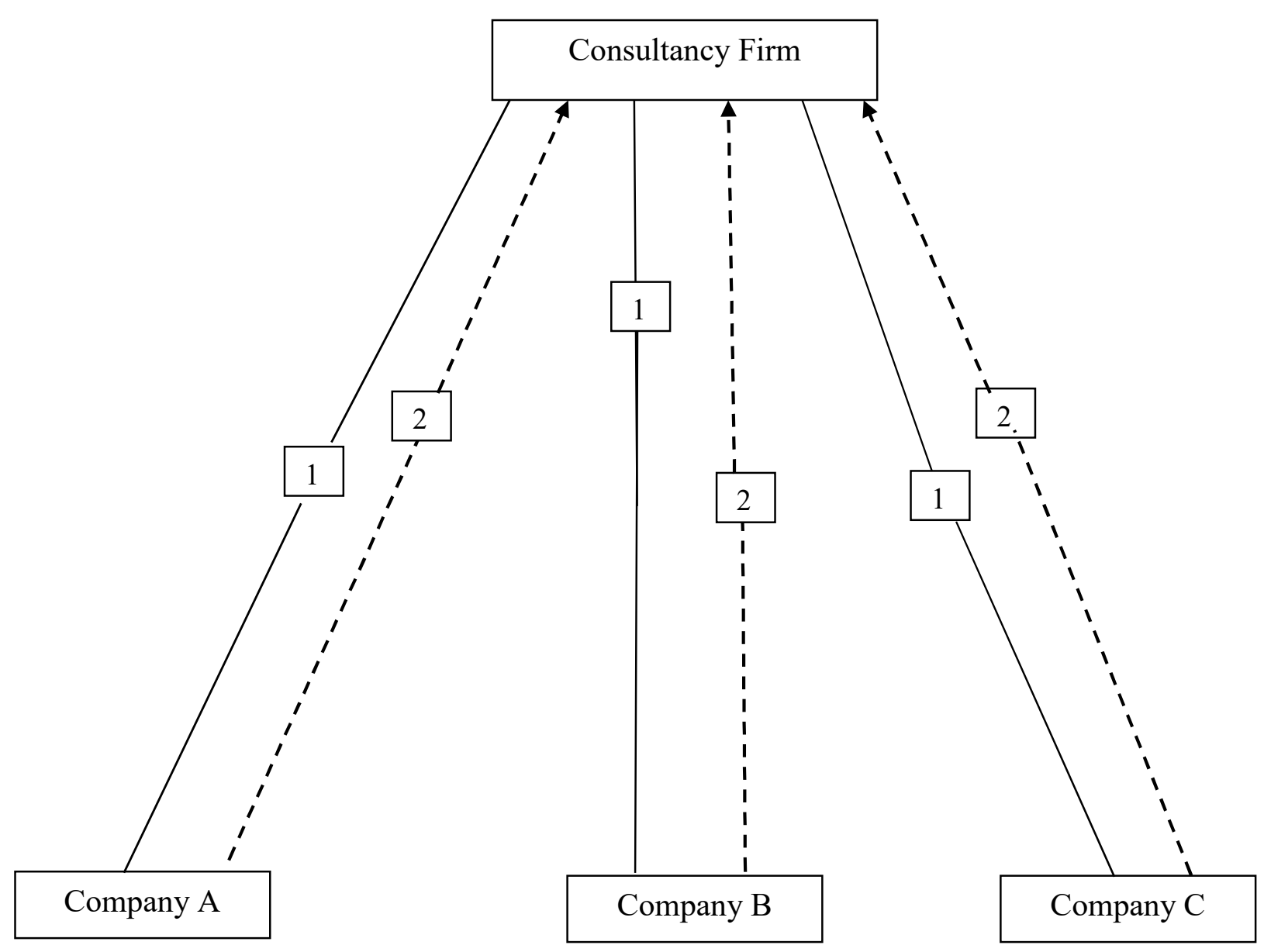

1. A consultancy firm provides and sells services to Companies A, B and C

2. Companies $\mathrm{A}, \mathrm{B}$, and $\mathrm{C}$ pay the wage/fees to the consultancy firm.

Fonte: SALEEM, M.Y. Islamic Commercial Law, 2013, p.55. 
O musawamah é um tipo de venda regular na qual o preço das mercadorias pode ser tratado como barganha entre o vendedor e comprador, sem nenhuma referência ao preço pago ou custo incorrido pelo formador. É diferente da Murabaha a respeito da fórmula de preço. Ao contrário de Murabaha, o vendedor, na musawamah, não é obrigado a revelar seu custo. Ambas as partes negociam o preço. Todas as outras condições relevantes para Murabaha são para Musawamah também. Musawamah pode ser usado onde o vendedor não está em posição de determinar precisamente os custos das mercadorias que ele está oferecendo vender.

Outro acordo muito utilizado é o istisnāh, sendo um acordo contratual de manufatura de bens e mercadorias, permitindo o pagamento adiantado e entrega futura ou um pagamento futuro e entrega futura. Também é descrito como um contrato com o vendedor que fornece a ambos, o material e o trabalho para manufatura de um produto definido, por um preço conhecido e entregueem uma data especificada. É um contrato único de venda que tem suas características específicas que o distingue de outros contratos de venda. $\mathrm{O}$ contrato de istisnāh irá se distinguir, pois não envolve trabalho como o Mudarabah entre outros, além de que seu produto não existe e ainda será fabricado. Istisnāh pode ser usada para fornecer a facilidade de financiar a fabricação ou construção de casas, plantas, projetos ou construção de pontes, estradas e rodovias.

O contrato Bai Muajjal literalmente significa uma venda de crédito. Tecnicamente é uma prática financeira adotada por bancos islâmicos que toma a forma de murabaha muajjal. É um contrato no qual o banco ganha uma margem de lucro no seu preço de compra e permite ao comprador pagar o preço das mercadorias em uma data futura em um montante fixo ou em parcelas. Deve mencionar expressamente o custo da mercadoria e a margem de lucro que é acordada mutualmente. O preço fixado para a mercadoria em tal transação pode ser o mesmo preço à vista ou abaixo ou acima do preço à vista.

A mudarabah é uma parceria no lucro entre o capital e o trabalhador em que uma parte fornece os fundos enquanto a outra fornece perícia e gerenciamento. Qualquer lucro é dividido entre as duas partes (pré-acordado), sendo que a perda é apenas de quem entra com o capital.

Outro contrato muito utilizado é a musharaka, que significa o relacionamento estabelecido, no contrato entre as partes, por mútuo consenso, para a divisão dos lucros e perdas em um negócio. É um acordo sob o qual o banco islâmico fornece fundos, que misturam fundos da empresa comercial e outros. Todos os fornecedores de capital têm 
direitos de participar do gerenciamento, porém não é necessariamente obrigatório. $\mathrm{O}$ lucro é distribuído entre as partes em taxas pré-acordadas, enquanto as perdas são distribuídas em proporção do respectivo capital contribuído.

O contrato de bai salam é um contrato no qual o pagamento adiantado é feito para mercadorias a ser entregue no futuro. $\mathrm{O}$ vendedor aceita suprir mercadoria especifica ao comprador numa data futura em troca um preço pago no contrato. É necessário que a qualidade da mercadoria a ser comprada seja especificada não deixando ambiguidade que possa se levar a uma disputa. O objeto desta venda são bens, não podendo ser ouro, prata ou moedas. Bai salam cobre quase tudo o que é capaz de ser definitivamente descrito em qualidade, quantidade e mão-de-obra.

Outro ponto importante sobre as diferenças entre os modelos é a questão do Corão proibir a jogatina e o bayu al- garar. O garar é compreendido como uma venda de itens cujas características e existência não são certas devido à natureza de risco que pode fazer do comércio um jogo. Há muitos hadith que proíbem o comércio de risco, dando sempre exemplos específicos destas transações. Os juristas têm buscado definições para esse termo e ainda criaram um conceito, yasir, que seria um risco menor, ou seja, uma transação financeira com um risco menor. O que o garar é exatamente nunca foi bem definido pelos juristas. O mesmo ocorre na criação do termo para um "risco menor", o caso do yasir.

Esses contratos permitiram que a banca islâmica pudesse se expandir. De fato, o pragmatismo na aplicação do Islã criou um sistema rico de formas de aplicação da lei na economia. Esses modelos são utilizados também no sistema internacional, ou seja, podemos perceber que não há impedimento na possibilidade de relacionamento com outros modelos, desde que sejam aplicados esses contratos, que não destoam do modelo tradicional capitalista.

\subsection{A Lei Islâmica Internacional}

Uma das ramificações da lei islâmica é a Siyar, ou seja, a lei islâmica internacional, que regula as relações internacionais das sociedades islâmicas. Essa lei, porém, acaba sendo mal interpretada pela visão que se possui sobre o jihad e pela experiência das Cruzadas. Guardamos ainda uma memória perturbadora sobre a Guerra Santa, que acaba trazendo certo prejuízo tanto ao Islã quanto ao Cristianismo e também 
ainda lidamos com a questão do fundamentalismo islâmico e do terrorismo que se expandiu pelo Século XXI. Essa visão foi construída baseada em certos episódios das relações islâmicas internacionais compreendidas independentemente do corpo da Siyar, mas não pode representar toda a fundação da concepção islâmica.

Devido à globalização, o aspecto da lei islâmica internacional ganha importância internacional, principalmente os aspectos econômicos. Os legisladores devem ter em mente que a lei econômica internacional islâmica terá de enfrentar a realidade política e ideológica da competição internacional.

Essa lei possui um processo evolucionário natural que envolve a acumulação e adaptação de coexistência e competição de valores e experiências, o engajamento destas perspectivas conflitivas poderia contribuir positivamente para o desenvolvimento de uma lei internacional realmente "internacionalizada". Pelo estudo da economia islâmica e o desenvolvimento da história, podemos recontar aqui os eventos e assim tornar visível e atender ao propósito de nosso texto, pois é necessário compreender que está presente nos muçulmanos a ideia de que o que é necessário para o desenvolvimento da economia internacional e o desenvolvimento das relações internacionais se faz através da lei islâmica. ${ }^{304}$

O elo entre a lei econômica internacional e a economia sugere que existe uma forte justificação de um componente multidisciplinar em se estudar a lei econômica internacional, ou seja, a necessidade de cooperação internacional na área econômica, a necessidade de melhoria das organizações internacionais e a própria necessidade de alocação de poder nas organizações internacionais demonstram o que é necessário para salvaguardar os interesses de todos democraticamente, implementar melhorias e aplicar a visão dentro do comércio internacional. Por cultivar uma perspectiva multidisciplinar e que aborda várias jurisprudências, os estudiosos poderão compreender uma lei econômica internacional que aborde em si várias disciplinas e metodologias, e assim possa de fato ser mais justa - o quanto possível - em sua aplicação global.

Para o professor Hadavinia, em entrevista no Irã, é uma responsabilidade dos países islâmicos procurarem trabalhar na área legislativa internacional, inspirando um sistema de justiça:

${ }^{304}$ KHADDURI, Majid. The Islamic Law of Nations Saybanis Siyar. USA: The John Hopkins Press, 1966, p.38. 
"O Islã não diz para cessar qualquer tipo de relação, porque isso na religião seria injusto. Temos que fazer isso quando aquilo não encontra os preceitos Islâmicos, no Irã que você encontra muitos tipos de negócios internacionais de contrato, joint ventures e outros. Sim. Mas o que é nosso dever? Devemos trabalhar em uma legislação adequada para inspirar as regras e regulamentos para que o regimento islâmico de justiça seja cumprido, as regras nas leis econômicas e comerciais internacionais também prevaleçam.Então, o que disse na conferência de Oman, há quatro anos. Nós dissemos que vocês não prepararam um sistema baseado na justiça. Este é o ponto principal que mencionamos e isso deve funcionar e deve se mover em direção a uma espécixe de preparação e legislação baseada na justiça no futuro.

Há alguns poucos trabalhos de pesquisadores que apreciam a diversidade religiosa e cultural, ${ }^{305}$ ou daqueles que vêm de tradições de "terceiro mundo" e se sentem obrigados a descobrir soluções legais para os problemas comerciais e de desenvolvimento de suas nações. Como um todo, apesar do status de lei universal, é perceptível que a prática da lei internacional permanece conectada com os estados ocidentais, dando uma formação tendenciosa ${ }^{306}$ à natureza da lei econômica internacional - esta ligada às tradições legais e métodos de interpretação política baseados em premissas competitivas e de concepção etnocêntrica entre as culturas. Ou seja, é necessária a modernização para que esta se torne realmente democrática.

$\mathrm{O}$ sistema internacional atual reflete as características do imperialismo e liberalismo americanos, não oferecendo assim muito espaço para as nações que apresentam interesses divergentes, ou tentam adentrar ao sistema numa condição de "terceiro-mundo", sem condições de competir. O professor Hadavinia ainda argumenta que é necessário uma adaptação:

"Ele precisa de alguns tipos de adaptações e acreditamos que a filosofia do Islã vai ser levada a um exemplo mais contundente como é o Iraniano. Como é baseado na economia real. É muito importante. Não no dinheiro que faz dinheiro. Se você tem uma pesquisa no Irã e esses projectos tenham sido feito pelos bancos, você vê um grande número de subsidios: fábricas ... Eu não sei ... Muitas, muitas coisas foram produzidas: as universidades têm sido feitas pelos bancos, esta é, professor (nome) e diz, o sistema econômico islâmico é uma economia muito realista, realista no sistema de pensamento."

\footnotetext{
${ }^{305}$ COOMBE, R. The Cultural Life of Things: Anthropological Approaches to Law and Society in Conditions of Globalization, IN: American University Journal of International Law \& Policy, 1995, p.792-793.

306 A ideia de uma formação tendenciosa é somente da autora, que tomando por base a globalização do capitalismo a partir da Segunda Guerra Mundial exporta o modelo capitalista e liberal americano, suas ideologia e bases teóricas na formação das Organizações Internacionais, dando pouco espaço a outros países, suas culturas e crenças.
} 
Não é possível escapar da conclusão de que a competição e a coexistência entre as culturas são parte de uma vida internacional, que muitas vezes parece ir contra a demanda de uma imposição de um sistema capitalista e liberal. A História tem mostrado ao homem que é necessário maior esforço para cooperação para que se mantenha a paz.

\subsubsection{Relações econômicas internacionais no Islã}

Para os muçulmanos, Deus criou o homem dentro das nações, as quais devem essencialmente cooperar no comércio e desenvolvimento, aprendendo entre si. O Islã vê a economia global como uma extensão da economia doméstica. Portanto, os princípios similares que governam os relacionamentos domésticos governarão os relacionamentos internacionais.

O Islã aceita as tradições para o comércio, reconhece a necessidade que os muçulmanos têm para viver e comercializar e que precisam viver em harmonia e lidar com não muçulmanos. Os Estados Islâmicos, que constituem a Ummah, estão sob a obrigação de conduzir suas relações econômicas com o resto do mundo baseados nos princípios legais e morais islâmicos e por consenso de ambas as partes. ${ }^{307}$ De fato, há valores éticos universais que serão encontrados no cristianismo e no islamismo. Não podemos negar que os valores da democracia liberal, os direitos humanos e pluralismos, aplicados na economia e instituições monetárias, poderiam trazer a justiça e uma ordem econômica harmoniosa.

A ordem econômica internacional que tem emergido como um resultado da dominação do capitalismo tem-se mostrado caótica, trazendo apenas a exploração dos países mais fracos pelos países fortes economicamente. As nações poderosas economicamente de fato não possuem interesse em se adaptar aos princípios éticos que ditam para a sociedade.

O livre mercado no qual nosso sistema econômico opera, que postula certa racionalidade, falha na distribuição dos ganhos no comércio, não trazendo justiça e igualdade de participação nas sociedades. O modelo liberal de fato tem falhado na

307 “Ó fiéis, não consumais reciprocamente os vossos bens, por vaidades, realizai comércio de mútuo consentimento e não cometais suicídio, porque Deus é Misericordioso para convosco". Corão (4:29); "Que atendem ao seu Senhor, observam a oração, resolvem os seus assuntos em consulta e fazem caridade daquilo com que os agraciamos". (Corão 42:38) 
promessas de aceleração do crescimento econômico do "terceiro mundo", da melhoria de sua distribuição de renda, e falha como um guia para uma era de liberdade e governança justa e, com isso, temos um sistema econômico internacional de problemas, sem justiça e organização. Temos por exemplo, desemprego com inflação, empobrecimento nos países desenvolvidos, privação em meio à afluência, disparidades regionais, poluição ambiental, poder econômico ilimitado de corporações globais, consumismo, exploração internacional através do auxílio da fraca estrutura do comércio.

O atual sistema internacional está apenas aprisionando os países em desenvolvimento que, desta forma, podem permanecer sempre à mercê das grandes economias e de suas corporações internacionais. Em essência, a globalização envolve a subordinação dos seres humanos para a maximização dos lucros das grandes corporações, a teoria da dependência.

A economia islâmica, com seu modelo, busca apresentar uma ética diferente para o mercado. Do ponto de vista teológico, os princípios da justiça, amanah (confiança), irmandade, benevolência na busca de um sistema de tratamento justo, mútuo reconhecimento de igualdade, cumprimento das promessas e cooperação são elementos essenciais para a promoção da justiça e igualdade no sistema econômico internacional e o desenvolvimento de boas relações.

\subsubsection{Justiça e benevolência no contexto internacional da distribuição da riqueza}

Um ponto importante dos ensinamentos islâmicos é que a felicidade humana é atingida não somente pela busca do desenvolvimento espiritual, é necessário dar ênfase à busca do desenvolvimento econômico, social e político para que haja melhoria das condições de vida e o verdadeiro propósito da vida seja atingido.

O Islã apresenta a teoria de que o homem é responsável pela propriedade e riqueza, que Deus o deixa encarregado de seus bens na Terra e lhe oferece o direito de propriedade privada. O Islã também obriga a pessoa a empregar seu capital e commodities dentro do escopo da sharia, não de acordo com seus desejos egoístas. A lei islâmica que guia o comércio é ampla, dando grande abertura para o comércio internacional ${ }^{308}$.

${ }^{308}$ SIDDIQI, M. Nejatullah. The Role of State in the Economy: An Islamic Perspective, 1996, p. 99. 
Os conceitos aplicados à economia doméstica serão levados ao mercado internacional, ou seja, as qualidades intrínsecas cobradas dos muçulmanos deverão também ser implantadas para o sistema internacional. ${ }^{309}$ Apresentamos aqui alguns pontos deste debate, buscando mostrar as regras essenciais para a economia.

\subsubsection{Amanah (Confiança)}

O Islã apresenta uma lista de obrigações na lei islâmica como sagrada e confiável $^{310}$. O conceito de Amanah coloca o homem sob a obrigação de todos os preceitos e injunções da lei islâmica. Para o Islã, todas as coisas originadas na Terra vieram e pertencem a Deus e o homem se apresenta como seu Khalifah (vice-gerência), e deve utilizar seus privilégios de forma sábia e dentro do escopo da lei islâmica ${ }^{311}$. Cada pessoa é individualmente e diretamente responsável a Deus pela fiel execução desta enorme confiança depositada. A qualidade desta confiança é importante, pois é um ponto de medida destes profetas $^{312}$, já que o Corão atribui esta qualidade ao Profeta, pois para o muçulmano, amanah é um sinal do imam (crença) ${ }^{313}$

Ainda dentro deste raciocínio, o conceito de propriedade privada que está estabelecido nas tradições semíticas é reafirmado no Corão e na Sunna ${ }^{314}$. Em vez de modificar o conceito de propriedade ou riqueza, o Corão e a Sunna especificam os termos,

\footnotetext{
${ }^{309}$ Essa defesa foi debatida com alguns pesquisadores na Universidade Internacional de Qom, onde o Professor Tavakoli argumentou que a economia ainda está sendo estudada em sentido doméstico, mas os estudiosos têm por ideia rever o pensamento islâmico econômico interno na área internacional.

310 "Por certo que oferecemos o confiado dos céus, da terra e das montanhas, porém se recusaram de responsabilizara-os por ele e a recebê-lo, porém o homem se encarregou dele, porque é injusto e insensato." (Corão 33:72)

311 "Seu é tudo o que existe nos céus, o que há na terra, o que há entre ambos, bem como o que existe sob a terra." (Corão 20:6); "Meu irmão Aarão" (Corão 2:30); "Ele foi Quem vos designou legatários na terra e vos elevou uns sobre outros, em hierarquia, para testar-vos com tudo quanto vos agraciou. Teu Senhor é Destro no castigo, conquanto seja Indulgente, Misericordiosíssimo" (Corão 6:165); "Crede em Deus e em Seu Mensageiro, e fazei caridade daquilo que Ele vos fez herdar. E aqueles que, dentre vós, crerem e fizerem caridade, obterão uma grande recompensa." (Corão 57:7)

312 "Os que respeitarem suas obrigações e seus pactos" (Corão 23:8)

313 "Realmente, revelamos-te o Livro, a fim de que julgues entre os humanos, segundo o que Deus te ensinou. Não sejas defensor dos pérfidos" (Corão 4: 105)

${ }^{314} \mathrm{O}$ conceito de propriedade privada pode ser traçado do sistema judaico-cristão assim como nas tradições greco-romana.
} 
ou seja, indicam claramente quando deve ocorrer a propriedade privada e como o homem deve atuar na vice-gerência e deve ser responsável pelos recursos econômicos. ${ }^{315}$

Esta responsabilidade ou confiança pode ser vista em três aspectos: ${ }^{316}$ (1) o consumo deve ser moderado, evitando-se as extravagâncias; ${ }^{317}$ (2) no uso de sua riqueza, uma pessoa deve ser acercar-se pelos limites da lei islâmica; (3) deve usar sua riqueza de uma maneira que não prive outros dos benefícios de seus direitos e propriedades. O Corão ordena que o respeito ao direto de propriedade deve ser estendido a todos os seres humanos, não importando sua fé ${ }^{318}$, pois a lei islâmica não discrimina entre o muçulmano e não-muçulmano, ou estrangeiro, referente à propriedade, aos direitos e aos contratos.

O mundo material para o Islã é apenas uma forma dos seres humanos demonstrarem sua fidelidade a Deus. Pelo seu comportamento referente ao uso e aquisição de riqueza e o ganho, todos mostrarão a fidelidade do homem a Deus ${ }^{319}$, pois em sua sabedoria, Ele não distribuiu a riqueza aos homens de forma igualitária, dando mais a uns que a outros ${ }^{320}$, assim também como a intelectualidade ${ }^{321}$, portanto a sabedoria deverá ser usada no uso da riqueza e dos dons.

\footnotetext{
315 "Que os avarentos, que negam fazer caridade daquilo que com que Deus os agraciou, não pensem que isso é um bem para eles; ao contrário, é prejudicial, porque no Dia da Ressurreição, irão, acorrentados, com aquilo com que mesquinharam. A Deus pertence a herança dos céus e da terra, porque Deus está bem inteirado de tudo quanto fazeis." Corão (3:180); "Não entregueis aos néscios o vosso patrimônio, cujo manejo Deus vos confiou, mas mantende-os, vesti-os e tratai-os humanamente, dirigindo-vos a eles com benevolência." (Corão 4:5); "Ele foi Quem vos designou legatários na terra e vos elevou uns sobre outros, em hierarquia, para testar-vos com tudo quanto vos agraciou. Teu Senhor é Destro no castigo, conquanto seja Indulgente, Misericordiosíssimo." (Corão 6:165); "Por certo que aqueles que recitam o Livro de Deus, observam a oração e fazem caridade, privativa ou paladinamente, com uma parte daquilo com que os agraciamos, almejam um comércio imorredouro. " (Corão35:29)

316 Timur Kuran, The Economic System in Contemporary Islamic Thought: Interpretation and Assessment, 18 (2) International Journal of Middle East Studies, 1986, p. 137

317 "Ó filhos de Adão, revesti-vos de vosso melhor atavio quando fordes às mesquitas; comei e bebei; porém, não vos excedais, porque Ele não aprecia os perdulários." (Corão 7:31)

318 "Entre os adeptos do Livro há alguns a quem podes confiar um quintal de ouro, que te devolverão intacto; também há os que, se lhes confiares um só dinar, não te restituirão, a menos que a isso os obrigues. Isto, porque dizem: Nada devemos aos iletrados. E forjam mentiras acerca de Deus, conscientemente. " (Corão 3:75)

319 "Porém, uma vez observada a oração, dispersai-vos pela terra e procurai as graças de Deus, e mencionai muito Deus, para que prospereis. " (Corão 62:10)

320 "Não ambicioneis aquilo com que Deus agraciou uns, mais do que aquilo com que (agraciou) outros, porque aos homens lhes corresponderá aquilo que ganharem; assim, também as mulheres terão aquilo que ganharem. Rogai a Deus que vos conceda a Sua graça, porque Deus é Onisciente. " (Corão 4:32)

${ }^{321}$ Importante lembrar aqui que para os muçulmanos o real sucesso não será advindo nesta vida, mas sim depois da morte e o sucesso não depende da riqueza material, mas sim de sua obediência
} 
Para os muçulmanos, a existência humana tem sido tão desordenada que há muita divergência, variedade e não equidade ${ }^{322}$, o que obriga ao homem que busque o uso da riqueza de acordo com a lei islâmica, ou seja, o uso moderado ${ }^{323}$, o não desperdício ${ }^{324}$ para que haja uma distribuição de renda de forma mais adequada. ${ }^{325}$

Esses ideais de fato não podem ser atingidos a menos que o governo esteja intimamente envolvido. O governo no Islã tem um papel importante na manutenção do mercado internacional que reduz a ação do individuo referente à sua propriedade e atividades econômicas, caso não esteja dentro do escopo de ação da lei islâmica. ${ }^{326}$

Através da instituição da hisbah ${ }^{327}$ é monitorado o comportamento dos indivíduos referente ao mercado e, através do conceito de amanah, ${ }^{328}$ o mecanismo de distribuição

a Deus. Todas as pessoas tem condições de servir a Deus, portanto a maior riqueza esta distribuída de forma igual.

322 "E entre os Seus sinais está a criação dos céus e da terra, as variedades dos vossos idiomas e das vossas cores. Em verdade, nisto há sinais para os que discernem." (Corão 30:22); “Ó humanos, em verdade, Nós os criamos de macho e fêmea e vos dividimos em povos e tribos, para reconhecerdes uns aos outros. Sabei que o mais honrado, dentre vós, ante Deus, é o mais temente. Sabei que Deus é Sapientíssimo e está bem inteirado."(Corão 49:13); "Deus favoreceu, com a Sua mercê, uns mais do que outros; porém, os favorecidos não repartem os seus bens com os seus servos, para que com isso sejam iguais. Desagradecerão, acaso, as mercês de Deus! " (Corão $16: 71)$

323 "São aqueles que, quando gastam, não se excedem nem mesquinham, colocando-se no meiotermo"(Corão 25:67)

324 "Porque os perdulários são irmãos dos demônios, e o demônio foi ingrato para com o seu Senhor."(Corão 17:27)

325 "Interrogam-te a respeito da bebida inebriante e do jogo de azar; dize-lhes: Em ambos há benefícios e malefícios para o homem; porém, os seus malefícios são maiores do que os seus benefícios. Perguntam-te o que devem gastar (em caridade). Dize-lhes: Gastai o que sobrar das vossas necessidades. Assim Deus vos elucida os Seus versículos, a fim de que mediteis" (Corão 2:219); "As esmolas são tão-somente para os pobres, para os necessitados, para os funcionários empregados em sua administração, para aqueles cujos corações têm de ser conquistados, para a redenção dos escravos, para os endividados, para a causa de Deus e para o viajante; isso é um preceito emanado de Deus, porque é Sapiente, Prudentíssimo." (Corão 9:60); "Perguntam-te que parte devem gastar (em caridade). Dize-lhes: Toda a caridade que fizerdes, deve ser para os pais, parentes, órfãos, necessitados e viajantes (desamparados). E sabei que todo o bem que fizerdes, Deus dele tomará consciência " (Corão 2:215)

326 Timur Kuran, The Economic System in Contemporary Islamic Thought: Interpretation and Assessment, 18 (2) International Journal of Middle East Studies, 1886, p.143-144

327 Literalmente significaria um presente, ou doação. Tecnicamente se explica como a transferência de propriedade sem nenhuma consideração material. O Profeta exortou os muçulmanos a doarem presentes um aos outros, sendo assim este é um dos valores importantes dentro da sociedade islâmica. O objetivo era cultivar a cooperação entre as pessoas. Deste termo na área financeira teremos extensões, sempre dando o significado de algum tipo de doação.

328 Literalmente significa lealdade, honestidade. Tecnicamente é um importante valor da sociedade islâmica nas negociações e também se refere a depósitos em confiança. Uma pessoa pode manter uma propriedade em confiança por alguém, as vezes expresso em contrato e as vezes por implicância de um contrato. 
de riqueza é tornado viável no Islã. ${ }^{329}$ Podemos citar aqui para exemplificar a questão da distribuição da riqueza, realizada através do infaq ${ }^{330}$, sadaqah ${ }^{331}$, zakat, waqf $f^{32}$ e qard hasan ${ }^{333}$, os quais alguns são compulsórios e outros recomendáveis.

O Zakat é uma caridade obrigatória, basicamente 2,5\% da riqueza acumulada, funcionando desde o princípio do Islã como uma forma de encorajar a distribuição da riqueza. Assim o dinheiro circularia. Esse sistema providenciaria uma rede que beneficiaria a população mais pobre e não penalizaria os grupos mais ricos, de forma a manter certa estabilidade. ${ }^{334}$ No entanto, este sistema se apresenta como fraco no processo de distribuição de riqueza, sendo que os governantes necessitam desenvolver outras formas, já que a economia globalizada é mais complexa do que os simples sistemas do passado.

Segundo a lei islâmica, o individuo tem a obrigação de usar suas propriedades tanto consigo e com sua família, não podendo privar esta de ser usada, pois beneficia a economia. Também não pode utilizar estes bens com extravagância e negociar sempre de forma justa. Todos estes pontos são buscados na construção da lei islâmica, mas são necessárias diversas análises e reorientações para uma sociedade cada vez mais complexa.

\subsubsection{Justiça no Islã}

O conceito de justiça é um dos principais dentro da lei islâmica e sua base se encontra no Corão e Sunna. ${ }^{335}$ É também muito amplo no que se relaciona ao sentido

\footnotetext{
${ }^{329}$ Não é um sistema em partes que engloba apenas a lei, mas entrará no escopo moral e religioso. 330 al-'infaq literalmente significa gastos. Tecnicamente significa o gasto que dispensamos voluntariamente em favor dos pobres e dos necessitados.

${ }^{331} \mathrm{Al}$-sadaqah significa literalmente caridade. Os muçulmanos que possuem riquezas além de certos limites são incentivados a caridade.

${ }^{332}$ Normalmente se refere a propriedade dada em usufruto. Essa propriedade não pode ser vendida, herdada e nem doada a ninguém.

${ }^{333} \mathrm{Al}$-qard al-hasan literalmente significa um empréstimo virtuoso, ou seja, um empréstimo com a estipulação de um retorno da soma principal no futuro sem nenhum acréscimo.

334 Timur Kuran, The Economic System in Contemporary Islamic Thought: Interpretation and Assessment, 18 (2) International Journal of Middle East Studies, 1989 p.143-144

${ }^{335}$ Assim como em outros sistemas, no Islã teremos diferentes zonas de justiça, por exemplo, criminal coberta pelo sistema qisas, hudud e taqzir e; no âmbito familiar e justiça econômica (muamalat); administrativa (siasah) e internacional (siyar).
} 
legal ${ }^{336}$, social ${ }^{337}$, moral ${ }^{338}$ e econômico, ${ }^{339}$ cobrindo assim todos os aspectos da vida dos seres humanos. A lei islâmica é ao mesmo tempo lei e moralidade, além de ser uma religião e trazer uma lista de regras comportamentais (etiqueta) para o homem.

336 "Ó fiéis, sede perseverantes na causa de Deus e prestai testemunho, a bem da justiça; que o ódio aos demais não vos impulsione a serdes injustos para com eles. Sede justos, porque isso está mais próximo da piedade, e temei a Deus, porque Ele está bem inteirado de tudo quanto fazeis." (Corão 5:8) "Ó fiéis, quando a morte se aproximar de algum de vós e este se dispuser a fazer um testamento, que apele para o testemunho de dois homens justos, dentre vós, ou de dois estranhos, se se achar viajando pela terra quando isto acontecer. Deverá detê-los, depois da oração, e fazêlos prestar juramento por Deus, deste modo: A nenhum preço venderemos o nosso testemunho, ainda que o interessado seja um dos nossos parentes, nem ocultaremos o testemunho de Deus, porque, se assim fizermos, estaremos entre os pecadores."( Corão 5: 106); "Dize ainda: Meu Senhor só ordena a equidade, para que vos consagreis a Ele, em todas as mesquitas, e O invoqueis sinceramente. Assim como vos criou, retornareis a Ele." (Corão 7:29); "Deus ordena a justiça, a caridade, o auxílio aos parentes, e veda a obscenidade, o ilícito e a iniquidade. Ele vos exorta a que mediteis. " (Corão 16:90); "E quando dois grupos de fiéis combaterem entre si, reconciliaios, então. E se um grupo provocar outro, combatei o provocador, até que se cumpram os desígnios de Deus. Se porém, se cumprirem (os desígnios), então reconciliai-os equitativamente e sede equânimes, porque Deus aprecia os equânimes." (Corão 49:9)

337 "Se temerdes ser injustos no trato com os órfãos, podereis desposar duas, três ou quatro das que vos aprouver, entre as mulheres. Mas, se temerdes não poder ser equitativos para com elas, casai, então, com uma só, ou conformai-vos com o que tendes à mão. Isso é o mais adequado, para evitar que cometais injustiças."'(Corão 4:3); "Consultar-te-ão acerca das mulheres; dize-lhes: Deus vos instruiu a respeito delas, assim como acerca do que vos é ditado no Livro, referente às mulheres órfãs, às quais não entregais o que lhes é destinado, embora tencioneis desposá-las; o mesmo (diga-se), com relação às crianças que são oprimidas. Sede justos para com os órfãos. Sabei que de tudo o bem que fizerdes, Deus estará inteirado." (Corão 4:127);

338 "Não podereis, jamais, ser equitativos com vossas esposas, ainda que nisso vos empenheis. Por essa razão, não declineis demasiadamente uma delas, deixando-a como se estivesse abandonada; porém, se vos reconciliardes e temerdes, sabei que Deus é Indulgente, Misericordiosíssimo." Corão 4:129); "Ó fiéis, sede perseverantes na causa de Deus e prestai testemunho, a bem da justiça; que o ódio aos demais não vos impulsione a serdes injustos para com eles. Sede justos, porque isso está mais próximo da piedade, e temei a Deus, porque Ele está bem inteirado de tudo quanto fazeis." (Corão 5:8) "Ó fiéis, quando a morte se aproximar de algum de vós e este se dispuser a fazer um testamento, que apele para o testemunho de dois homens justos, dentre vós, ou de dois estranhos, se se achar viajando pela terra quando isto acontecer. Deverá detê-los, depois da oração, e fazê-los prestar juramento por Deus, deste modo: A nenhum preço venderemos o nosso testemunho, ainda que o interessado seja um dos nossos parentes, nem ocultaremos o testemunho de Deus, porque, se assim fizermos, contar-nos-emos entre os pecadores."(Corão 5:106); "E (o Senhor ordenou-vos, ao dizer): Esta é a Minha senda reta. Segui-a e não sigais as demais, para que estas não vos desviem da Sua. Eis o que Ele vos prescreve, para que $\mathrm{O}$ temais."(Corão 6:153)

339 "Deus manda restituir a seu dono o que vos está confiado; quando julgardes vossos semelhantes, fazei-o equidade. Quão excelente é isso a que Deus vos exorta! Ele é Oniouvinte, Onividente." (Corão 4:58); "Ó fiéis, sede firmes em observardes a justiça, atuando de testemunhas, por amor a Deus, ainda que o testemunho seja contra vós mesmos, contra os vossos pais ou contra os vossos parentes, seja contra vós mesmos, contra os vossos pais ou contra os vossos parentes, seja o acusado rico ou pobre, porque a Deus incumbe protegê-los. Portanto, não sigais os vossos caprichos, para não serdes injustos; e se falseardes o vosso testemunho ou vos recusardes a prestá-lo, sabei que Deus está bem inteirado de tudo quanto fazeis.“(Corão 4:135); "E (o Senhor ordenou-vos, ao dizer): Esta é a Minha senda reta. Segui-a e não sigais as demais, 
No Islã, a justiça poderá ser vista em dois contextos, primeiramente no relacionamento entre o homem e Deus, ou seja, o contexto pessoal, ou seja, deverá ser observado o comportamento do ser humano, o homem deverá procurar um equilíbrio entre suas forças internas - razão, agressão e desejo - devendo sempre atuar de acordo com a lei islâmica. No segundo contexto, o que importa é a justiça de domínio publico, ou seja, a justiça atingida levando em consideração os direitos dos outros. Em outras palavras, a pessoa deve agir buscando seus direitos, também preenchendo suas obrigações, no comércio, nas negociações, em sua vida social e nas relações governamentais.

Justiça neste contexto é o estabelecimento do correto, $h a q q$, e este termo no Islã é visto como direito e obrigação, pois o direito de uma pessoa está ligado a ambas as questões. Para se atingir a justiça no âmbito doméstico e no âmbito internacional, o sistema deve carregar a justiça em seu sentido substantivo e em seus procedimentos e, no Islã, o Estado deve promover a justiça social e colaborar com outras nações para promover o desenvolvimento e prosperidade do mundo, através de uma ordem econômica internacional igualitária ${ }^{340}$.

A lei islâmica apresenta aspectos importantes na busca da justiça no sistema, ponto que apresentamos anteriormente, ou seja, os muçulmanos têm os bens de Deus confiados à sua posse. Administrar bem é de fato um ato de devoção aos muçulmanos, portanto, no uso de sua riqueza, através de transações comerciais, negócios e investimentos, ele ou ela deverá respeitar a propriedade de Deus e os direitos legais e morais dos outros.

Outro ponto importante é a questão do respeito mútuo. Uma sociedade justa, para o Islã, deve oferecer respeito a todos os indivíduos através de sua organização social. As regras servem para prevenir que se faça injustiça comercial enquanto se lida com outros. Não cumprindo, sofrerá a retribuição e punição. ${ }^{341}$ Para atingir a justiça na instituição da

para que estas não vos desviem da Sua. Eis o que Ele vos prescreve, para que O temais." (Corão 6:153); "Ó povo meu, disponde da medida e do peso com equidade; não defraudeis os humanos em seus bens e não pratiqueis a devassidão na terra, como corruptores. "(Corão 11:85); "Cumpri o pacto com Deus, se houverdes feito, e não perjureis, depois de haverdes jurado solenemente, uma vez que haveis tomado Deus por garantia, porque Deus sabe tudo quanto fazeis." (Corão 16:90);

${ }^{340}$ Haqq bait al-mal se refere ao sistema de impostos cobrados pelo estado.

341 "Deus ordena a justiça, a caridade, o auxílio aos parentes, e veda a obscenidade, o ilícito e a iniquidade. Ele vos exorta a que mediteis " (Corão 16:90) 
propriedade privada e a comercialização dos fatores de produção, o Islã estabelece regras para sua regulamentação. Neste ponto, a questão dos não-muçulmanos é também levada em consideração, sendo que, mesmo vivendo em um Estado Islâmico, eles podem consumir seus produtos e estão isentos da lei islâmica aplicada aos muçulmanos.

Acima de tudo, a justiça é uma obrigação coletiva em que cada membro da sociedade é responsável. ${ }^{342}$ Os estudiosos nem sempre concordam com os procedimentos de como conseguir chegar à justiça. Não há questões referentes à qualidade da justiça na lei islâmica para a economia e os negócios, tais como a riba e a obrigação do zakat, porém os pontos de vista serão diversos quanto à implementação. ${ }^{343}$ Para Kuran, o sistema econômico e social é muito complexo e, do ponto de vista islâmico, a justiça deveria resultar em pelo menos dois princípios básicos: igualdade e justiça. No Islã, os conceitos de $a d l$ (igualdade) e qist (justiça) desempenham um papel crucial no estabelecimento da justiça no sistema econômico internacional.

\subsubsection{Igualdade}

Igualdade ( $a d l$ ') é um aspecto da justiça que pode ser derivado da lei islâmica, em muitos aspectos, preocupada com a manutenção da harmonia (i’tidal) da sociedade, já que os ensinos corânicos buscam a igualdade e a dignidade da humanidade. ${ }^{344}$ Os membros da sociedade não devem violar este sistema e a lei islâmica está estabelecida de forma a manter o sistema adequado à justiça.

Para o Islã, apesar das diferenças nas oportunidades para acumulação de capital, todos os seres humanos têm igual direito à subsistência. A aquisição de riqueza é para beneficiar os seres humanos e também para ser de uso coletivo social, com o intuito de tornar a sociedade mais equilibrada, oferecendo iguais oportunidades. ${ }^{345}$ Os ricos têm por

\footnotetext{
342 "Sois a melhor nação que surgiu na humanidade, porque recomendais o bem, proibis o ilícito e credes em Deus. Se os adeptos do Livro cressem, melhor seria para eles. Entre eles há fiéis; porém, a sua maioria é depravada." (Corão 3:110)

${ }^{343}$ KURAN, Timur. On the Notion of Economic Justice in Contemporary Islamic Thought, IN: Internacional Journal of Middle East Studies, p.172

344 "Enobrecemos os filhos de Adão e os conduzimos pela terra e pelo mar; agraciamo-los com todo o bem, e preferimos enormemente sobre a maior parte de tudo quanto criamos." (Corão 17:70)

${ }^{345}$ O Islã reconhece as diferenças de status social na sociedade, tais como entre o homem e a mulher. "Consultar-te-ão a respeito da herança de um falecido, em estado de "kalala"; dir-lhesás: Deus já vos instruiu a este respeito: se uma pessoa morrer, sem Ter deixado prole e tiver uma irmã, corresponderá a metade de tudo quanto deixe; e se ela morrer, ele herdará dela, uma vez
} 
ordem utilizar de misericórdia e sua riqueza deverá contribuir a outros. A questão de justiça dentro do sistema islâmico é algo extremante complexo, já que seu sistema deve considerar que o homem está sempre na presença de Deus, tanto o pobre quanto o rico.

\subsection{A justiça econômica internacional}

Se buscarmos discutir justiça nas relações referentes à lei econômica internacional, a lei islâmica não limita sua preocupação com a justiça em um senso abstrato, nem com sua aplicação prática em todos os campos relacionados tais como comércio, monetário e financeiro e cooperação para o desenvolvimento. O sistema legal e econômico internacional e as questões morais devem se dirigir para a implementação de reformas sociais com o desejo de construir uma sociedade justa e equitativa. A implementação processual da justiça é atingir uma justiça social e distributiva na economia politica islâmica.

Tomando vantagem da vulnerabilidade e da falta de regulamentação do sistema financeiro internacional, muitos têm-se tornado ricos, algo que é ilegal para o Islã. Apesar da economia não ser nada mais do que tornar-se mais rico, não está em tensão com a ideia mundial da coexistência porque a interação entre atores econômicos no mercado internacional está envenenada demais para ser regulada e assim, subsequentemente, criar a justiça no meio ambiente. Então, para o Islã é necessário reestruturar as leis.

No Islã, o ato de equilíbrio em si é fundamental e é alcançado por meio de centralização e mediação entre resultados. A tarefa teórica é achar como os resultados devem ser ligados para formar uma unidade equilibrada e quais são as condições para tal ligação. Para Kuran, ${ }^{346}$ os ideais islâmicos não estão livres da manipulação e de falsa aplicação nas mãos de certos governantes islâmicos. No entanto, dado o fato de que durante certos períodos, quando a administração islâmica da justiça foi aplicada e tais ideais foram colocados em prática com êxito, indicaram que não é impossível que estas regras sejam implementadas no mundo atual. Deve-se estar alerta a certo nível de coerção pelos Estados. É ainda necessário estabelecer a ordem social requerida na sociedade, mas

que esta não deixe filhos. Porém, se ele tiver duas irmãs, estas herdarão dois terços do que ele deixar; e se houver irmãos e irmãs, corresponderá ao varão a parte de duas mulheres. Deus vo-lo esclarece, para que não vos desvieis, porque é Onisciente." (Corão 4:176)

346 Timur Kuran, The Economic System in Contemporary Islamic Thought: Interpretation and Assessment, IN: International Journal of Middle East Studies, 1986 p.141. 
esta aplicação externa por si só não vai funcionar. ${ }^{347}$ Internamente, religiões ou ideologias dirigem e dão apoio aos seres humanos a respeitarem ou negligenciarem as leis. Portanto, os valores sociais e os mecanismos devem ser abordados nas leis econômicas, de forma que se consiga tornar realidade os ideais.

Amor, concordância, simpatia, confiança mútua e bondade têm sido a mensagem de todas as religiões e cada nação tem aprendido lições essenciais em sua pureza. Para o Islã, somente um princípio de abnegação e serviços, o qual a fé em Deus tem inspirado, através de uma irmandade, pode ser atingida. No Islã, essa irmandade é dividida em três tipos: irmandade por genealogia ${ }^{348}$, irmandade no Isla $\tilde{a}^{349}$ e irmandade da humanidade ${ }^{350}$.

A irmandade existe entre todas as pessoas em conta da ancestralidade comum traçada de Adão ${ }^{351}$. Para o Islã, Deus criou todas as pessoas da mesma fonte: de Adão e Eva, não importando cor, etnia ou status social. Somos todos descendentes da mesma fonte. Todos estamos habitando o mesmo mundo. O homem não pode viver isolado, portanto deve atuar como uma irmandade.

É irracional e ilógico que as pessoas perpetuamente evitem umas às outras ou lutem continuamente, como ocorre atualmente. Se tem havido egoísmo, ódio e derramamento de sangue, apesar da existência de religiões e sua mensagem de amor, tal fato existe devido ao ambiente humano ${ }^{352}$, quando este cede aos desejos egoístas ${ }^{353} \mathrm{e}$ às tentações que lhe são impostas. ${ }^{354}$ Por isso o Islã tem tomado medidas necessárias para

${ }^{347}$ KURAN, Timur. On the Notion of Economic Justice in Contemporary Islamic Thought, IN: Internacional Journal of Middle East Studies, p.142.

${ }^{348}$ Pode ser baseado por relações biológicas.

349 "Sabe que os fiéis são irmãos uns dos outros; reconciliai, pois, os vossos irmãos, e temei a Deus, para vos mostrar misericórdia " ( Corão 49:10)

350 "Enobrecemos os filhos de Adão e os conduzimos pela terra e pelo mar; agraciamo-los com todo o bem, e preferimos enormemente sobre a maior parte de tudo quanto criamos." (Corão 17:70); "assim como com as Nossas clemência e pureza, e foi devoto" (Corão 19:13)

351 "O povo de Ad, o Faraó, os irmãos de Lot," (Corão 49:13)

${ }^{352} \mathrm{O}$ Islã não assume a ideia de que o homem é naturalmente ruim, o ambiente muda o homem e com isso é necessário lutar para atingir a bondade novamente. Sahih, p.298.

353 "Estão-vos vedados: a carniça, o sangue, a carne de suíno e tudo o que tenha sido sacrificado com a invocação de outro nome que não seja o de Deus; os animais estrangulados, os vitimados a golpes, os mortos por causa de uma queda, ou chifrados, os abatidos por feras, salvo se conseguirdes sacrificá-los ritualmente; o (animal) que tenha sido sacrificado nos altares. Também vos está vedado fazer adivinhações com setas, porque isso é uma profanação. Hoje, os incrédulos desesperam por fazer-vos renunciar à vossa religião. Não os temais, pois, e temei a Mim! Hoje, completei a religião para vós; tenho vos agraciado generosamente sem intenção de pecar, se vir compelido a (alimentar-se do vedado), saiba que Deus é Indulgente, Misericordiosíssimo."(Corão $5: 3)$

354 “(Eis aqui) um Livro, que te foi revelado para que não haja receio em teu peito, e para que, com ele, admoestes os incrédulos, para que seja uma mensagem aos fiéis. ” (Corão 7:2) 
preservar a humanidade da divisão e discórdia. Uma destas medidas é o princípio da irmandade de humanidade.

As leis islâmicas foram designadas para facilitar o sucesso e o aperfeiçoamento das condições da vida humana neste mundo, assim como na vida pós-morte. ${ }^{355}$ Os muçulmanos creem que para conseguirem a misericórdia de Deus, é necessário cumprir com os mandamentos. ${ }^{356}$ A misericórdia humana deve ser estendida mesmo aos animais, pois Deus mostrará sua misericórdia e amor aos que mostram misericórdia e amor.

Outra qualidade que está intimamente ligada à misericórdia é a benevolência, que é enfatizada no Islã. ${ }^{357}$ A benevolência é um comportamento considerado como uma resposta espiritual natural de um crente, ou seja, um verdadeiro crente está preparado para dividir com outros aquilo que possui, como forma de gratidão a Deus pelo que Ele lhe tem dado.

\subsubsection{Regras para o Mercado Internacional no Islã}

As bases para as transações (muamalah) na lei islâmica consistem em que tudo é mubah ou permissível, exceto aqueles já estabelecidos como haram (proibido) no Corão ${ }^{358}$, tais como a riba, o consumo de álcool, porco etc. Algumas transações, mesmo que não tenham rejeição direta do Corão e da Sunna, carregam elementos que são abominados pela lei islâmica e, através do exercício da ijma e qiyas, são tornadas proibidas.

\footnotetext{
355 "E não te enviamos, senão como misericórdia para a humanidade.(" (Corão 21:107)

356 "Louvado seja Deus, Senhor do Universo." (Corão 1:2); "Jamais enviaríamos um mensageiro que não devesse ser obedecido, com a anuência de Deus. Se, quando se condenaram, tivessem recorrido a ti e houvessem implorado o perdão de Deus, e o Mensageiro tivesse pedido perdão por eles, encontrariam Deus, Remissório, Misericordiosíssimo. (Corão 4:64);”'Ó fiéis, temei a Deus e crede em Seu Mensageiro! Ele vos concederá dupla porção da Sua misericórdia, dar-vosá uma luz(1606), com que vos encaminhará e vos perdoará; e Deus é Indulgente, Misericordiosíssimo."(Corão 57:28); “Entre eles há aqueles que injuriam o Profeta e dizem: Ele é todo ouvidos. Dize-lhes: É todo ouvidos sim, mas para o vosso bem; crê em Deus, acredita nos fiéis e é uma misericórdia para aqueles que, de vós, creem! Mas aqueles que injuriarem o Mensageiro de Deus sofrerão um doloroso castigo.” (Corão 9:61)

357 "Deus ordena a justiça, a caridade, o auxílio aos parentes, e veda a obscenidade, o ilícito e a iniquidade. Ele vos exorta a que mediteis." (Corão 16:90)

358 "E que vos impede de desfrutardes de tudo aquilo sobre o qual foi invocado o nome de Deus, uma vez que. Ele já especificou tudo quanto proibiu para vós, salvo se vos fordes obrigados a tal? Muitos se desviam, devido á luxúria, por ignorância; porém, teu Senhor conhece os transgressores." (Corão 6:119)
} 
O Islã não rejeita todo o sistema de mercado praticado antes do tempo do Profeta $^{359}$, no entanto, o Corão explicitamente requer que o livre mercado de comércio aberto seja baseado em transações consensuais, voluntárias e éticas. ${ }^{360}$ Porém, o Islã tem estabelecido certos princípios e limites para as atividades econômicas internacionais do homem. Assim o padrão de produção, troca e distribuição da riqueza deve se adequar aos paradigmas islâmicos de justiça e igualdade. Estes princípios econômicos que aparecem no Corão e na Sunna são gerais e específicos. O Islã requer o uso do ijtihad em sua aplicação em diferentes momentos e contextos. Como um todo, o Islã não só permite o mercado internacional, mas também providencia mecanismos para mantê-lo operativo em seu dinamismo natural sem ser prejudicado por uma manipulação injustificada como as práticas monopolistas, especulação e outros comportamentos antimercado e anticooperativo.

A lei islâmica tem tornado o comércio de alguns produtos, cujo o seu uso é proibido pelo Islã, ilegais. Um muçulmano pode apenas comercializar tais produtos e commodities que o Islã declara halal, ou permitido. Também tem estabelecido certos princípios e limites para as atividades do comércio internacional. Todas as transações

\footnotetext{
359 “Os que praticam a usura só serão ressuscitados como aquele que foi perturbado por Satanás; isso, porque disseram que a usura é o mesmo que o comércio; no entanto, Deus consente o comércio e veda a usura. Mas, quem tiver recebido uma exortação do seu Senhor e se abstiver, será absolvido pelo passado, e seu julgamento só caberá a Deus. Por outro lado, aqueles que reincidirem, serão condenados ao inferno, onde permanecerão eternamente."(Corão 2:275); "Ó fiéis, cumpri com as vossas obrigações. Foi-vos permitido alimentar-vos de reses, exceto o que vos é anunciado agora; está-vos vedada a caça, sempre que estiverdes consagrados à peregrinação. Sabei que Deus ordena o que Lhe apraz. " (Corão 5:1); "Não disponhais do patrimônio do órfão senão da melhor forma, até que ele chegue à puberdade, e cumpri o convencionado, porque o convencionado será reivindicado."(Corão 17:34); “Ó fiéis, quando contrairdes uma dívida por tempo fixo, documentai-a; e que um escriba, na vossa presença, ponha-a fielmente por escrito; que nenhum escriba se negue a escrever, como Deus lhe ensinou. Que o devedor dite, e que tema a Deus, seu Senhor, e nada omita dele (o contrato). Porém, se o devedor for insensato, ou inapto, ou estiver incapacitado a ditar, que seu procurador dite fielmente, por ele. Chamai duas testemunhas masculinas de vossa preferência, a fim de que, se uma delas se esquecer, a outra recordará. Que as testemunhas não se neguem, quando forem requisitadas. Não desdenheis documentar a dívida, seja pequena ou grande, até ao seu vencimento. Este proceder é o mais equitativo aos olhos de Deus, o mais válido para o testemunho e o mais adequado para evitar dúvidas. Tratando-se de comércio determinado, feito de mão em mão, não incorrereis em falta se não o documentardes. Apelai para testemunhas quando mercadejardes, e que o escriba e as testemunhas não seja coagidos; se os coagirdes, cometereis delito. Temei a Deus e Ele vos instruirá, porque é Onisciente.”(Corão 2:282); “Ai dos fraudadores” (Corão 83:1)

360 "Ó fiéis, não consumais reciprocamente os vossos bens, por vaidades, realizai comércio de mútuo consentimento e não cometais suicídio, porque Deus é Misericordioso para convosco." (Corão 4:29); "Ele é Que lhes faz descer a chuva, após o desespero (da seca), e dispensa a Sua misericórdia (a quem Lhe apraz), porque é o Protetor, o Laudabilíssimo." (Corão 42:38)
} 
envolvendo os juros e troca de tangíveis similares, porém com quantidades desiguais, são proibidas pelo Islã $\tilde{a}^{361}$.

Quando ouro e prata ou diferentes moedas fiduciárias são trocadas por outras, a quantidade deve ser diferente, porém a troca deve ser simultânea. ${ }^{362}$ Jogos de azar e apostas que envolvem deliberadamente o risco também são proibidos ${ }^{363}$ e práticas especulativas que são realizadas somente para ganho também são proibidas, pois ganho deverá vir com uma atividade realizada, o trabalho estará aqui envolvido.

No Corão, se encontrarão regras a respeito do peso, medidas e controles ou posse do objeto. Caso ainda não se tenha a mercadoria em mãos, é proibida a sua venda ou comercialização. ${ }^{364}$

O Islã demanda que se mantenha um padrão de honestidade e integridade nos negócios. Devem-se divulgar todos os problemas com a mercadoria que está sendo vendida, caso contrário, implica-se em fraude, a qual é ofensa pública no Islã. A religião islâmica proíbe qualquer tipo de fraude e o Profeta condenava o negociante que ludibriava seus clientes. A questão do juramento sob o contrato ainda é considerado importante no Islã. Atualmente, para o Islã, a declaração feita pelos produtores das etiquetas dos produtos funcionam como um juramento sobre o produto, sendo que assim estará de acordo com a lei e, descumprindo, caberá ressarcimento ao cliente.

No Islã, há certa discussão sobre a possibilidade de manipulação no mercado. ${ }^{365}$ Há leis proibindo as práticas antitruste, consideradas como imorais. Práticas que desenvolvem o monopólio, fixação de preços, cartel e acumulação são consideradas ilegais no Islã. ${ }^{366}$ As regras modernas hoje do mercado, tais como práticas restritivas de

\footnotetext{
${ }^{361}$ AL-QARADAWI,Yusuf. The Lawful and the prohibited in Islam.Al-Falah Foundation, sem data, p.251

${ }^{362}$ Assadr irá abordar esse tema em sua pesquisa para o governo do Kuait. Despende não grande parte sobre isso, mas a base de ideias é igual à utilizada na atualidade.

363 "E aos medianias enviamos seu irmão Xuaib, que lhes disse: Ó povo meu, adorai a Deus, porque não tereis outra divindade além d'Ele! Já vos chegou uma evidência do vosso Senhor! Sede leais, na medida e no peso! Não defraudeis o próximo e não causeis corrupção na terra, depois de ela haver sido pacificada! Isso será melhor para vós, se sois fiéis."(Corão 7:85)

${ }^{364}$ M.N. Siddiqi. Principles of International economic relations in Islam.IN M.A. Mannan; Monzer Kahf e Ausaf Ahmad, International Economic Relations from Islamic Perspective. Jeddah, Saudi Arabia: Islamic Research and Training Institute, 1992, p.17.

${ }^{365}$ Iremos encontrar regras na Sunna sobre a questão de se encontrar com os mercadores antes de chegarem ao mercado, assim não dando a oportunidade para estes de conhecer as condições de negociação, o preço padrão daquele local, ou seja, uma forma de tirar vantagem para a compra, sendo assim proibido no Islã. BUKHARI, Sahih, Vol.3, Book 34 N $^{\circ} 360-374$

${ }^{366}$ BUKHARI, Sahih. Book 34. On sales and Trade
} 
alguns negócios, leis antitruste, cooperação industrial, dumping, cartel e monopólios estão em sintonia com as regras islâmicas.

Podemos perceber que o Islã idealiza não apenas uma sociedade justa e próspera para os muçulmanos, mas visualiza um sistema econômico justo e igualitário e em pleno desenvolvimento para a sociedade toda. Com a globalização, para os muçulmanos, a sociedade deve buscar se unir para o desenvolvimento, de forma a chegar ao desenvolvimento justo e ao atendimento das necessidades humanas.

A lei islâmica busca levar, através das regras internacionais, seus valores e crenças que podem contribuir para o desenvolvimento de um regime universal, com a esperança de trazer um sistema que possa contribuir para uma vida de melhor qualidade ao homem.

\subsubsection{O Estado e suas Funções no Mercado}

O Islã, assim como outras religiões abraâmicas, considera os impulsos e atividades econômicas do homem como normais e benéficos para o desenvolvimento do humano. ${ }^{367}$ A economia de fato deve ser encorajada e aplicadas apenas algumas limitações necessárias. Com base na ideia de equilíbrio social do Islã, busca-se a justiça social e, nessa base, as atividades econômicas domésticas e internacionais são temas de regulamentação através da colaboração do Estado.

A teoria econômica do Islã geralmente aborda dois tipos de controles nas atividades econômicas. Primeiro, o envolvimento político que permite que o Estado participe diretamente em certas indústrias com o desejo de atingir o estado de bem-estar social. Aqui, o Estado intervém quando é claro que o setor privado é incapaz de certas atividades econômicas, especialmente na construção de infraestrutura pública, entre outras.

O Estado pode intervir se deseja certo padrão no nível de desenvolvimento econômico e social da sociedade ou em circunstâncias especiais como guerras. Segundo, o envolvimento indireto através do poder e órgãos do Estado. Através das funções regulatórias e da supervisão o Estado intervém e organiza a economia doméstica e

\footnotetext{
${ }^{367}$ Essa visão em parte é compartilhada por Assadr, sendo que o autor considera que a essência do homem na busca de desejos egoístas torna a economia algo difícil. Essa visão pareceu bem difundida na atualidade pelas entrevistas.
} 
internacional. O professor e pesquisador Hadawinia, em entrevistas, deu grande ênfase no papel do Estado para o equilíbrio econômico citando exemplo do Irã:

"Sistema islâmico e o sistema bancário islâmico no Irã. Há dois pontos
importantes. Uma delas é que no regulamento deste sistema, temos sido
bem sucedidos em trinta anos. Nós combinamos a relação perfeita entre
a regulação do sistema bancário islâmico e os seres humanos. [...]
porque depois da revolução, o estado no Islã têm apoiado os mercados.
$[\ldots . . . .$. mas às vezes, você sabe, por causa da guerra, e a tensão desde o
início de uma revolução,a situação econômica, por vezes, não era tão
próspera. Esse era o problema. Assim, problema mais importante para
os bancos era a situação, como a guerra, a tensão, então foi o banco que
deveria ter tentado estar na posição vertical, para não ser dependente do
orçamento nacional ."

Para o professor, só foi possível a islamização e a organização do sistema através do Estado, suas lei e uso da força. Esse Estado encoraja o homem e as corporações a serem éticos no processo de interação no ambiente econômico internacional, mas isso só pode se tornar realidade através da intervenção, fazendo da lei islâmica uma prática diária, tanto no ambiente doméstico quanto no internacional.

A instituição islâmica da Hisbah pode ser uma referência aqui. Hisbah é uma autoridade que regula e supervisiona as atividades comerciais e possui poder de interferir nas áreas sob seu poder. Outro tipo de envolvimento estatal na economia internacional é o desenvolvimento de relações através da política fiscal. As finanças do Estado e as privadas ocupam um importante espaço na economia islâmica. De fato, as finanças têm dado força ao desenvolvimento da economia islâmica e também são importantes na questão do desenvolvimento da sociedade islâmica.

A lei islâmica, através da instituição de uma politica fiscal rígida ${ }^{368}$ e missões de caridade, procura promover a justiça e igualdade no sistema internacional, sendo que ainda há impostos específicos para a área internacional. Para o Islã, o governo é obrigado a proteger os direitos econômicos e obrigações dos indivíduos e da sociedade através da intervenção e supervisão. Com isso será reduzida a manipulação do mercado por grupos e grandes companhias e será possível melhorar a distribuição da riqueza.

\footnotetext{
${ }^{368} \mathrm{~A}$ instituição de tributos como o Baitul-mal, Zakat, sadaqah, waqf, infaq, qadr-hasan e outras obrigações financeiras como o amanah redistribuem efetivamente a riqueza nos estados islâmicos; não é considerado ainda um método perfeito e não atua diretamente uma igualdade, mas projeta um auxilio para as classes mais baixas da sociedade.
} 
O relacionamento entre o estado islâmico e outras nações deve sempre ser pautado na igualdade, ou seja, nunca numa posição superior ou mesmo inferior. A este ponto foi dado grande destaque pelo professor Hadawinia:

\begin{abstract}
"Alguns princípios, por exemplo, um princípio é presente no regulamento entre estados islâmicos e estados não-islâmicos, isso não deveria ocorrer... termina então com a maestria dominante do estado não Islâmico para o estado Islâmico. A relação deve ser igual. Não é como no mestre e escravo. Este é um ponto importante para a coexistência. Mas, o ponto é que, se a nova situação no mundo, como a guerra, criou algumas novas regulamentações, proibindo essa interação. Então essas regulamentações, como a convenção internacional, não são contra a sharia islâmica, devemos aceitá-las. Este é o ponto. Por que não? É por isso que é necessario seguir a convenção internacional. Só que ... a única coisa é que se essa convenção for contra os preceitos Islamicos, qual então será o ponto?
\end{abstract}

Para o Islã, a participação e cooperação na economia globalizada são requisitos para o desenvolvimento do Estado. Uma aproximação econômica e tecnológica entre os estados irá diretamente e indiretamente promover a estabilidade e a paz, porém é perceptível para os líderes religiosos que essa globalização tem seu impacto negativo, trazendo a cultura e os hábitos ocidentais e trazendo também o capitalismo, que promove uma desigualdade social entre as nações.

A globalização hoje representa em si um desafio para o Islã em sua jornada de promover um sistema justo. Quando questionado sobre a justiça dentro das organizações internacionais, Professor Tavakoli respondeu com certa indignação:

"[..] os países que participaram nesta conferência e o ponto definido foi que para preparar este novo projeto de lei do comércio internacional, não se tem qualquer confronto entre os países em desenvolvimento e os países islâmicos. A necessidade da presença dos países islâmicos para adaptar estes regulamentos é de suma importância. O ponto é que embora estas regras e regulamentos, por exemplo, no âmbito da $\mathrm{OMC}$, falem sobre o apoio das economias menores e os países em desenvolvimento praticamente o poder está nas mãos das superpotências. Na prática, as pequenas economias e os países em desenvolvimento não são protegidos. Esta é a realidade. Em recente lei, eles dizem que devemos tentar apoiar os países e assim por diante ... Assim, devemos encontrar uma maneira e devemos estar presente neste organizações e convenções para gradualmente para remover a injustiça." 
Muitos países têm dado voz à injustiça do sistema internacional que de fato apresenta uma ordem legal na qual não cabem as diferenças culturais e religiosas de muitas nações.

A questão da qualidade da justiça dentro do sistema internacional será sempre uma questão fundamental. No entanto, significância dos princípios, normas e costumes também parecem não ser fundamentais para a construção das leis econômicas internacionais. $\mathrm{O}$ desenvolvimento e qualidade das leis referentes à justiça para as leis do comércio internacional parecem estar mais ligados às negociações e aos acordos. Uma vez ratificados os acordos de um Estado islâmico, este deve cumprir com todos os termos. Um país que decida se tornar membro da Organização Internacional do Comércio ou outra instituição econômica internacional baseada em acordos que são reconhecidos pela lei islâmica deve cumprir todas as regras e políticas que são derivadas destes acordos e confirmadas pelos membros dos estados islâmicos. Porém, o desenvolvimento do comércio e do multilateralismo não é um processo estático. É necessário preparar um processo progressivo do comércio e das regras para o desenvolvimento.

Negociação é um processo contínuo dentro da Organização Mundial do Comércio e a ideia de justiça internacional devia guiar os estados negociadores, porém o sistema não é pautado desta forma. Um dos problemas é que não há princípios claros para a justiça internacional dentro do moderno sistema de leis internacionais. A questão da justiça internacional ainda parece elusiva. É deixada para os estados a questão do que é justiça de fato. $\mathrm{O}$ que percebemos é que a justiça acaba sendo determinada pelos estados ricos e poderosos contra os que não tem muitas condições dentro do sistema ${ }^{369}$.

Apesar da igualdade existir na teoria, isso não ocorre de fato, já que os estados não desfrutam da mesma capacidade de exercer direitos e assumir obrigações. Na origem e desenvolvimento da lei internacional, a preocupação era mais com o relacionamento dos estados do que com o estabelecimento da justiça no sistema, até mesmo porque a questão da justiça entre as escolas legais é diversificada, sempre dependendo da escola jurisprudencial. ${ }^{370}$

No entanto, podemos afirmar que a prática da política externa nos países dominantes ainda seguirá o modelo liberal de Estado, aplicando uma política externa

\footnotetext{
369 HENKIN, Louis. International Law: Politics and Values. London: Martinus: Nijhoff Publishers, 1995, p.10.

${ }^{370}$ Geralmente são classificados em três tipos: os realistas ou positivistas, o humanista liberal ou progressista e o grupo dos radicais, teóricos críticos e pós-modernistas.
} 
realista, procurando a dominação dos recursos em beneficio de sua população, ou seja, podemos aqui compreender que a justiça internacional é essencialmente a justiça repensada por uma população em sentido doméstico. ${ }^{371}$ Negociações, consultas, reconciliações e poder persuasivo da comunidade será fator importante para as decisões das instituições multilaterais. Em negociações de comércio internacional, um acordo de barganha deve ter regras claras sobre o jogo e o mesmo desejo de agir com justiça, algo que torna o sistema complexo.

Depois de herdar o sistema do GATT, a OMC tem se expandido para incluir mais membros e, com esta expansão, o sistema tem mudado de um sistema de tarifas e quotas para um sistema que há de lidar com barreiras não-tarifárias, assim como um sistema de grandes regulações que pode de alguma forma distorcer ou abstruir o livre comércio de mercadorias e serviços.

A OMC tem um grande impacto na vida e no bem-estar de bilhões de pessoas, já que seus acordos e tratados influenciam o comércio de mercadorias. Um dos maiores problemas que enfrenta a humanidade é a questão de que as leis econômicas internacionais não beneficiam as pessoas dos países mais pobres tanto quanto as dos países mais ricos. O crescimento do comércio foi importante durante as últimas décadas, mas a renda é distribuída desproporcionalmente entre as pessoas. Para o Islã, é necessário o balanço entre os consumidores, produtores, governos, grupos ambientais e fabricantes, em vez de se ditar as regras e deixar o sistema sob o lobby das multinacionais. ${ }^{372}$

Sendo criada para o livre comércio e para a melhoria do padrão de vida em nível mundial, a OMC não tem cumprido praticamente com nenhum destes objetivos, seus acordos servem para as corporações multinacionais e acabam beneficiando os países mais ricos que os outros, ou seja, temos aqui uma falha em sua democracia.

O comércio é parte da tradição islâmica e a chave para os futuros estados islâmicos, uma forte ferramenta de crescimento, que eleva a prosperidade e o padrão de vida. ${ }^{373}$ Para o Islã, os muçulmanos e não-muçulmanos devem buscar organizar o comércio internacional como forma de beneficiar as futuras gerações. A lei islâmica encoraja as nações a cooperar e firmar acordos com o propósito do comércio justo e do

\footnotetext{
${ }^{371}$ As decisões de um Estado para o uso da força e sua politica internacional.

${ }^{372}$ No Islã, a decisão de algo importante deve passar pela syura (consultação); O Corão ordenava que o Profeta se consultasse com outros. (Corão 3:159)

373 Artigo XXXVI do GATT (1947) reconhece o comércio internacional como um meio importante para atingir o avanço econômico e social.
} 
desenvolvimento. ${ }^{374}$ Tem se tornado, nos últimos anos, principal desafio para todas as nações participar ativamente dos arranjos do comércio internacional multilateral de forma que possa ocorrer uma competição comercial aberta, justa e sem distorções.

Uma das funções principais da OMC é agir como um meio de conduta das relações comerciais internacionais entre os membros dos Estados, bilateralmente e multilateralmente. Particularmente, a OMC é para agir como um fórum de negociação para melhor liberalização do comércio e melhoria do no sistema internacional de comércio. ${ }^{375}$ De fato, a OMC não está em posição de fazer todos os países iguais e, para reduzir a desigualdade, deve talvez dar maior voz aos países pobres.

As decisões da OMC são atingidas por um consenso ${ }^{376}$, um método também usado pela lei islâmica conhecido como ijma, ou seja, uma decisão é considerada tomada por consenso, se nenhum membro que está presente na reunião em que a decisão está sendo tomada se opuser formalmente à proposta de decisão ${ }^{377}$, se não se chega ao consenso, irá ocorrer votação e a maioria dos votos vencerá. ${ }^{378}$ No entanto, o processo dentro da OMC parece ocorrer de tal forma que os países em desenvolvimento estão sempre na defensiva, com pouca oportunidade de colocar a frente seus interesses. Por outro lado, os países desenvolvidos são capazes de direcionar a Organização de forma a se beneficiarem.

Os Estados em desenvolvimento, ou o que importa aqui, os estados islâmicos são muito fracos, sendo que a maioria destes está perdido dentro desta selva de negociação e por várias razões estes não têm conseguido atingir bons acordos, pois pelo modo como as leis são aprovadas, os estados islâmicos precisam analisar as leis e muitas vezes passá-las por um processo de islamização e adaptá-las, se necessário.

Recentemente, os estados islâmicos têm participado da OMC em grupos de países em desenvolvimento como o Grupo 21. Dada a sua experiência limitada, capacidade técnica e força, somente alguns têm conseguido ser ativos em negociações e discussões. Países como Egito, Malásia, Paquistão, Nigéria e Indonésia têm estado ativos, mas outros países têm apresentado maior dificuldade.

\footnotetext{
374 Deve ser feito de forma justa, reconhecimento mútuo de direitos, cumprindo todas as promessas acordadas e cooperando com o desejo de se estabelecer uma justa e igualitária ordem econômica. SIDDIQI, M.N. Princípios da Economia Internacional. p. 13.

${ }^{375}$ Artigo III do Acordo de Marrakesh.

${ }^{376}$ Artigo IX (1) do Acordo de Marrakesh.

${ }^{377}$ Método adotado pelo GATT 1947.

${ }^{378}$ Artigo XI do Acordo de Marrakesh.
} 
Os 39 países islâmicos que estão na OMC são chamados a cooperar entre eles para formar um grupo islâmico que pode ganhar mais peso nas negociações e conseguir assim defender seus interesses. De vários estudos realizados, há um grande potencial econômico dos países islâmicos conseguirem ganhar com a globalização. No entanto, os membros do OIC estão ainda receosos com os efeitos negativos dos acordos da OMC. A abertura para serviços e mercados de capitais dos países islâmicos tem criado tremenda oportunidade para companhias multinacionais dos países mais desenvolvidos. Por outro lado, o fato destes países não acompanharem a tecnologia e não estarem plenamente adaptados à economia faz que os países em desenvolvimento tenham dificuldade de competir com as grandes corporações multinacionais. ${ }^{379}$ Com o gap entre os países desenvolvidos e os países islâmicos, o sucesso destes em ganhar espaço nos mercados depende do quanto conseguem ganhar nas negociações e deve-se também buscar regras mais justas e conseguir formar uma irmandade de cooperação nas negociações internacionais.

A tarefa hoje ainda é fazer com que estas instituições multilaterais possam trabalhar efetivamente com os Estados, promovendo as grandes preocupações dos pobres e dos vulneráveis. Para o Islã, todas as nações devem cooperar e criar uma irmandade, removendo o risco, assim como estes têm buscado realizar em sua economia doméstica.

\subsection{Regras do comércio}

Das leis islâmicas referentes à economia, regras substantivas são as normas legais que fornecem um padrão específico de comportamento. Para o Islã, a justiça se verá refletida no grau em que as regras satisfazem os requisitos de distribuição justa e igualitária de benefícios e custos. Isso resulta da formulação de limites morais e legais para facilitar o processo de relações econômicas internacionais. Então, a maximização do lucro, a eficiência do mercado, o preço subjetivo são balanceados através de uma distribuição igualitária e justa de benefícios através da aplicação da lei islâmica. ${ }^{380}$

\footnotetext{
${ }^{379}$ No Irã, em entrevista, alguns professores mencionaram a questão da não participação do Irã na OMC pelo fato de também não desejarem abrir seu mercado, pois sabem que o país não teria condições de competir com outros em determinados produtos e assim poderiam ter sua indústria nacional prejudicada.

${ }^{380}$ KURAN, Timur. The Discontents of Islamic Economics Morality, IN: American Economic Review, 1996 p. 438.
} 
Mesmo o homem sendo livre, para o Islã os bens estão apenas em sua confiança e deve se assegurar o uso correto destes e das atividades econômicas. ${ }^{381}$ Nos ganhos de lucros no comércio e investimento, o homem deve ser guiado por princípios rígidos e há regras para os modos de produção, marketing e consumo a serem seguidas. ${ }^{382}$ Em outras palavras, a lei islâmica, com seus princípios aplicados em sentido doméstico, tem se ampliado em sentido internacional, ou seja, o Islã com a expansão busca a ampliação e aplicação de seus princípios no sistema internacional.

\subsubsection{Acesso ao mercado}

O livre acesso ao comércio e mercado ocorre através da aplicação do princípio da não-discriminação que é a base dos acordos do GATT/OMC. ${ }^{383} \mathrm{O}$ desejo é criar a igualdade de condições de competição e proteger os participantes do mercado contra o comércio e a competição injusta. $\mathrm{O}$ acesso ao mercado está associado com a questão de um ótimo desempenho da $\mathrm{OMC}$, já que estes estão há longo tempo cobrindo as medidas de tarifas e não-tarifas e acordos entre os membros para a entrada de mercadorias nos mercados.

A lei islâmica acordará com as regras da $\mathrm{OMC}$, sendo que apenas dois pontos deverão ser ressaltados: a requisição da proteção da moralidade pública e os arranjos para o mercado halal.

\subsubsection{Proteção da moralidade pública}

As regras do antigo GATT/OMC permitem que os governos usem medidas restritivas de comércio para proteger diversos aspectos das preocupações nacionais, como

\footnotetext{
381 "Ele é o Primeiro e o Último; o Visível e o Invisível, e é Onisciente. Ele foi Quem criou os céus e a terra, em seis dias; então, assumiu o trono. Ele bem conhece o que penetra na terra e tudo quanto dela sai; o que desce do céu e tudo quanto a ele ascende, e está convosco onde quer que estejais, e bem vê tudo quanto fazeis. Seu é o reino dos céus e da terra, e a Deus retornarão todos os assuntos. Ele insere a noite no dia e o dia na noite, e é Sabedor das intimidades dos corações. Crede em Deus e em Seu Mensageiro, e fazei caridade daquilo que Ele vos fez herdar. E aqueles que, dentre vós, crerem e fizerem caridade, obterão uma grande recompensa."(Corão 57:3-7) ${ }^{382}$ Assadr aborda as regras do Corão para a produção, pós-produção, comércio e banking. ${ }^{383}$ São os elementos fundamentais dos artigos I e II do GATT 1947.
} 
a indústria doméstica, ${ }^{384}$ segurança nacional ${ }^{385}$ e as exceções gerais incluindo proteção de sua própria população, "moral pública", "tesouros nacionais"386 e os Estados têm usado estas exceções por diferentes razões. ${ }^{387}$

Um membro da OMC pode restringir a importação de produtos com base na politica de proteção da moral pública desde que não esteja sendo arbitrário ou haja uma discriminação injustificada entre países e que não importe produtos que envolvam tratados menos desfavoráveis que os produtos domésticos ${ }^{388}$.

A moralidade de fato motiva o controle do comércio e assim pressiona a lei doméstica e os tratados internacionais. Os estados têm há muito tempo assinado tratados e estabelecido leis para protegerem elementos de religiosidade local referentes ao comércio de mercadorias e serviços. A preocupação internacional com o ópio, pornografia, contrabando de bebidas alcoólicas ou importação de escravos estão iniciando moralmente, assim como religiosamente, uma campanha de mudança do sistema.

Em entrevista, o Professor Hadavinia menciona a questão dos produtos em que eles não teriam relacionamento com outros países por serem contra a lei islâmica:

"Sim, então nós estamos em apenas alguns pontos. Na economia
islâmica e no capitalismo, é possível que se confrontem, apenas o ponto
de que a sharia está dizendo:" isso é que você não pode usar ". todas
estas coisas. Então, nós somos livres para ter comércio. Nós não somos
um país protegido, podemos dizer. Mas, só temos alguns pontos que
temos de lidar. Mas talvez a porcentagem de noventa ou oitenta por
cento desta liberdade de interação, talvez para dois por cento, como eu
lhe disse, um dos produtos de barreiras que há no sistema capitalista "

Invocando a artigo XX (a), este poderia providenciar um espaço para que os estados islâmicos impusessem no comércio o controle de mercadorias e serviços que estão religiosamente e moralmente contra os seus precedentes. $\mathrm{O}$ artigo cobre tais atividades como a importação de músicas, literaturas ou filmes que são ofensivos religiosamente. Também cobre a importação de drogas ilegais, bebidas alcoólicas, porcos e outras

\footnotetext{
${ }^{384}$ Artigo XIX GATT 1947 - Ação emergente sob a importação de determinados produtos.

${ }^{385}$ Artigo XXI GATT 1947.

${ }^{386}$ Artigo XX(a) GATT 1947 e Artigo XIV de GATS.

387 O governo da Tailândia baniu a exportação de imagens de Buda para proteção de tesouros nacionais; o governo de Israel baniu a importação de carne não-kasher.

${ }^{388}$ Artigos XX(a) GATT e Artigo XVI (a) do GATS; Principio de "Tratamento da Nação mais favorecida" sob o Artigo I GATT 1947 e Artigo II do GATS e ARTIGO III GATT 1947.
} 
comidas não halal, equipamentos e serviços relacionados a jogos e risco e apostas. No entanto, com muitos estados islâmicos tendo uma sociedade multi religiosa, devem ser considerados os direitos dos cidadãos não-muçulmanos.

Ainda assim, a proteção da moralidade pública deve depender mais da regulamentação doméstica e as medidas de comércio seriam mais para a proteção em sentido geral. Outro desafio enfrentado pelos estados islâmicos é que estes tentam introduzir sua ética no sistema, procurando remodelar as questões como direitos dos animais, trabalho infantil, proteção ambiental, que podem afetar negativamente suas exportações.

\subsubsection{Mercado "halal"}

Pelas regras islâmicas, os muçulmanos devem consumir apenas os produtos com a classificação "halal” ou produtos seguros. No Islã, para a limpeza física e segurança do produtos, para consumo e uso externo, os requisitos islâmicos não divergem muito do padrão moderno, porém o consumo de alimento ou produtos usados externamente possuem um critério ${ }^{389}$, isto é, o produto deve preencher certos requisitos espirituais de limpeza, um termo que é referido como o halal. Animais haram, tais como suínos, cachorros e não abatidos corretamente, ou alimentos que possuem estes como ingredientes ou bebidas alcoólicas não são halal, então são proibidos.

Com a expansão do mercado de produtos halal e o rápido crescimento do comércio internacional, a Comissão $\operatorname{Codex}^{390}$ tem aprovado uma série de guias para o uso do termo halal. Essas instruções gerais são para permitir pequenas diferenças de interpretação entre as escolas islâmicas de pensamento, e é reconhecido que estes termos estão sujeitos à interpretação das autoridades dos países de importação. ${ }^{391}$ No entanto, o certificado garantido pelas autoridades religiosas do país de exportação deverá ser aceito a princípio pelo país de importação, a menos que a justificação por outra requisição específica seja dada.

Para um produto ser halal, todos os materiais brutos e ingredientes devem ser halal. Quaisquer utensílios, equipamentos ou maquinários usados na produção devem ser

\footnotetext{
${ }^{389}$ Halalan tayyiban

${ }^{390}$ Acordo aprovado em 1997. Codex Alimentarius Comission.

${ }^{391}$ Veja o preambulo do Guia.
} 
limpos de acordo com a lei islâmica. Um alimento halal deve ser livre de contaminação e não deve ter contato com substâncias haram durante a preparação, manufatura e processamento de armazenagem ou transporte. Para um animal ser halal ele deve ser abatido por um muçulmano invocando a frase "Bismillah" imediatamente antes de abater cada animal. ${ }^{392}$

Um ponto ainda controverso é a questão dos alimentos geneticamente modificados. Do ponto de vista islâmico, se as plantas são usadas como doadores de genes, não há necessidade de controversia. Haverá problemas se os produtos manipulados estão ligados a produtos proibidos pelo Islã. A Academia Islâmica da Fiqh ${ }^{393}$ não tem ainda apresentado uma fatwa a respeito deste tema.

Mesmo com um padrão internacional Codex para os produtos halal é necessário que seja coordenado um esforço no sentido de se estabelecer uma participação ativa dos estados islâmicos no programa de formação deste corpo de leis, garantindo a proteção dos direitos de consumo dos muçulmanos. Os estados islâmicos deveriam fazer uso de todas as brechas legais disponíveis para introduzir todas as regulações técnicas e requisitos da norma para garantir que tais produtos focados ao público muçulmano preencham os requisitos dos produtos halal. É necessário também introduzir uma etiqueta específica referente aos produtos, especificando se os ingredientes não são halal ou não são processados de forma halal.

Muitos países islâmicos têm sua própria regulação referente à importação de produtos, bebidas e produtos para os cuidados humanos, incluindo produtos médicos e farmacêuticos para aderir às necessidades da lei islâmica. No entanto, a harmonização destes padrões fragmentados deveria ser urgentemente desenvolvida para que um padrão universal respeitável seja criado para o sistema internacional. Os produtores têm sido ativos no sentido de desenvolver um mercado para os produtos halal. Já que compreender estes processos de fabricação e preparação está se tornando mais complicado e difícil, os

\footnotetext{
${ }^{392}$ Aqui também há a questão do procedimento correto para a morte do animal, sendo que deve ser poupado de sofrimento. $O$ animal deve ser morto com uma faca afiada e o corte deverá fazêlo perder o sangue imediatamente, sendo que perderá a consciência e terá uma morte rápida.

${ }^{393}$ The Islamic Fiqh Academy é um órgão subsidiário da Organization of the Islamic Conference, criado na terceira conferência islâmica em Meca, em Janeiro de 1981.Ali atuam especialistas que buscam repensar a situação dos muçulmanos como uma minoria em países não muçulmanos, em cada campo do conhecimento.
} 
estudiosos do Islã deveriam procurar atuar mais perto dos cientistas para determinar o halal e haram dos alimentos, ingredientes e processos. ${ }^{394}$

A questão foi colocada como fator importante durante as entrevistas. O Professor Tavakali menciona a questão do relacionamento entre os países capitalistas e o Irã:

\begin{abstract}
"Como eu mencionei em nosso último encontro, então o que são os problemas de agora? Talvez existam alguns obstáculos; talvez existam alguns tipos de problemas. Eu acabei de mencionar alguns problemas, por exemplo, existem algumas cepas internacionais para exemplos, alguns países estão a proteger os direitos dos animais, eu mencionei isso. Nós não gostamos do jeito que você abate de ovinos, ok, de modo que deve haver algum tipo de limitação para nos apoiar ou as ovelhas estão bem com o Irã, certo? Isso significa que existem alguns malentendidos ou talvez alguma diferença de valores, ou aqui estamos lendo algo mas são problemas como este ".
\end{abstract}

No entanto, muitos países islâmicos pobres ainda não possuem um mecanismo regulatório apropriado para proteger os consumidores de produtos considerados haram. De fato, os países islâmicos e desenvolvidos devem negociar uma estratégia para garantir o estabelecimento de uma proteção especial de forma que os produtos sejam desenvolvidos dentro da lei islâmica.

\title{
3.7.4 Politica Anticompetição
}

A eficiência econômica e o bem estar do consumidor que produz um resultado final global do bem-estar material para a sociedade têm sido os objetivos chave da política competitiva do sistema mercadológico. No entanto, no nível internacional, quanto a estes objetivos de competição, a lei poderia não oferecer o equilíbrio entre os níveis da economia, ou seja, a uma lei que beneficiasse os países em subdesenvolvimento e os países desenvolvidos. Trabalhando com as mesmas regras não se terá e igualdade entre as diferentes categorias de atores no sistema.

O conceito islâmico maslaha permite ao regulador levar em consideração desigualdades e o crescimento econômico dos participantes ao estabelecer um mecanismo

\footnotetext{
${ }^{394}$ Mencionamos devido ao processo dos transgênicos e produtos que são acrescentados. Nos EUA foram lançados 2 livros avaliando os alimentos que se encontram nas prateleiras americanas e isso se torna um manual aos muçulmanos, porém com o desenvolvimento rápido de novos produtos é ainda complicado para os muçulmanos decidirem o que consumir. De fato, os cientistas terão que trabalhar de forma conjunta com os religiosos de forma que estes possam interpretar a forma de produção e assim os produtos não violarem as leis do Islã.
} 
para a organização da competição multilateral. Além do mais, os novos desafios apresentados pela globalização têm significativamente mudado o mundo onde vivemos e têm mudado as prioridades das leis competitivas. A realidade do capitalismo moderno e o consumismo moldado pela globalização têm mudado a natureza do relacionamento entre o mundo desenvolvido e o subdesenvolvido. Isto é um elemento importante para ser levado em consideração em qualquer esforço para atingir uma regulamentação justa na competição global.

A lei islâmica aborda a sociedade de dois aspectos: a consciência humana pessoal $^{395}$ e a regulação externa ${ }^{396}$. Internamente, iman é a base do Islã, que é o conceito abstrato ou uma qualidade ligada ao amal (ações), porque as ações são a prova do iman. A ligação entre a fé e as ações corretas é componente inseparável do que constitui uma crença verdadeira. Devido a isto, o mecanismo da ética islâmica de negócios se inicia na área individual. Aqui se opera através da apelação para a consciência humana, taqwa (medo de Deus) e o desejo de sua benção na vida e após a morte ${ }^{397}$. Estes mecanismos são fundados na realização pessoal que se manifesta através das corretas ações. ${ }^{398}$ Para o Islã esse é o mecanismo mais forte, mais do que o controle governamental. ${ }^{399}$

A crença é de que o que mantém os fiéis cumpridores da lei islâmica são seu Iman e taqwa, pois estes não são vistos apenas como meros rituais, mas como qualidades espirituais ${ }^{400}$ e deverão ser vistos na prática do comportamento moral do muçulmano.

395 KURAN, Timur. The Economic System in Contemporary Islamic Thought: Interpretation and Assessment IN: International Journal of Middle East Studies 18 (02), p.136.

${ }^{396}$ Op cit 140.

397 "Deus lhes concedeu a recompensa terrena e a bem aventurança na outra vida, porque Deus aprecia os benfeitores." ( Corão 3:148); "Será dito aos tementes: Que revelou o vosso Senhor? Dirão: O melhor! Para os benfeitores, neste mundo, há uma recompensa; porém, a da outra vida é preferível. Que magnífica é a morada dos tementes!" (Corão 16:30)

398 "Indubitavelmente Deus conhece tanto o que ocultam, como o que manifestam. Ele não aprecia os ensoberbecidos." (Corão 16:23); "De sorte que não se prostram diante de Deus, Que descobre o obscuro nos céus e na terra, e conhece tanto o que ocultais como o que manifestais." (Corão 27:25);" Senão o que Deus permitir, porque Ele bem conhece o que está manifesto e o que é secreto." (Corão 87:7)

399 "E temei o dia em que retornareis a Deus, e em que cada alma receberá o seu merecido, sem ser defraudada " (Corão 2:281)

400 "Quanto àqueles que se apegam ao Livro e observam a oração, saibam que não frustraremos a recompensa dos conciliadores." (Corão 7:170); "Por certo que aqueles que recitam o Livro de Deus, observam a oração e fazem caridade, privativa ou paulatinamente, com uma parte daquilo com que os agraciamos, almejam um comércio imorredouro." (Corão 35:29); "Que são ativos em pagar o zakat. Que observam a castidade, Exceto para os seus cônjuges ou cativas - nisso não serão reprovados. Mas aqueles que se excederem nisso serão os transgressores. Os que 
Citemos como exemplo: zakat e sadaqah são descritos como meio de purificação, ${ }^{401}$ pois o doador irá se limpar da avareza e o recebedor da inveja e ódio, e se trará para a sociedade justiça, harmonia e estabilidade social.

Enquanto o Islã procura estabelecer um relacionamento especial entre seus fiéis, também reconhece a irmandade do homem. Para um muçulmano, é esperado que este trate um não muçulmano como um irmão e com tanta generosidade e amizade possível. ${ }^{402}$ O Islã então é visto como uma religião de serviço, ou seja, o trabalho do homem a serviço da humanidade é um trabalho de adoração deste homem a Deus. O Islã encoraja e espera o mesmo comportamento dos não muçulmanos.

Nas atividades econômicas, o Islã reconhece que somente a motivação interna, regrada pela ética islâmica não seria suficiente. Não serão todos os muçulmanos e não muçulmanos quea cumprirão voluntariamente. Desde o princípio do Islã, além de organizar o mercado, o governo tem garantido que todos os acordos devem ser feitos de forma justa, em formas de exploração e opressão nesses acordos. $\mathrm{O}$ envolvimento do governo no mercado levou à criação da instituição da hisbah - um departamento de inspeção que é responsável por parar o comércio adulterado e não saudável. ${ }^{403}$ No Estado moderno, este âmbito é coberto por regulamentações domésticas tais como Práticas do Comércio Injustas, Anticompetição e Proteção ao Consumidor. Em tais circunstâncias, o governo deve intervir para promover o maslahah. ${ }^{404}$

As praticas proibidas pela lei islâmica são:

Monopólio (ishtikar): no princípio do Islã, a prática do monopólio (istabadda) foi proibida pelo Profeta. O monopólio na lei islâmica é definido como a redução intencional da quantidade de produtos supridos, com a expectativa eminente de elevar o preço do produto. Geralmente, no Islã será proibida qualquer forma de manipulação no mercado

respeitarem suas obrigações e seus pactos, E que observarem as suas orações, Estes serão os herdeiros. Herdarão o Paraíso, onde morarão eternamente.”(Corão 23:4-11)

401 "Deus abomina a usura e multiplica a recompensa aos caritativos; Ele não aprecia nenhum incrédulo, pecador. "(Corão 2:276); "Por outra, àquela que se consagrar a Deus e a Seus Mensageiro, e praticar o bem, duplicaremos a recompensa e lhe destinaremos um generoso sustento.”(Corão 33:33); “Temei, pois, a Deus, tanto quanto possais, Escutai-O, obedecei-Lhe e fazei caridade, que isso será preferível para vós! Aqueles que se preservarem da avareza serão os bem-aventurados. (Corão 64:16)

402 Os princípios de confiança e irmandade universal foram discutidos acima, mostrando assim sua extensão do assunto e tema.

${ }^{403}$ Funções do Estado no Comércio.

${ }^{404}$ A doutrina do Maslahah. 
para artificialmente elevar o preço de um produto em particular para desvantagem do consumidor.

Fixação de preço (tas'eer): a fixação do preço pelas autoridades mercadológicas ou por cartel é proibida pelo Islã. Na ética islâmica, é necessário o respeito pela livre interação entre as forças de demanda e suprimento determinando o preço no mercado.

Restrição de novas firmas que entram no mercado: abusos na aquisição do mercado, aquisição de produtos, joint ventures ${ }^{405}$.

Do ponto de vista islâmico, o comércio internacional deve ser livre das atividades que prejudicam o mercado. O desenvolvimento dos métodos para o comércio dependem da lei islâmica, e os estados estão enfrentando novos desafios que as soluções nem sempre estão imediatamente disponíveis segundo os preceitos da lei. Os princípios gerais da lei islâmica providenciam uma base para a solução de problemas, porém é necessário que grande deliberação seja feita para o desenvolvimento de regras para novos temas e é necessário que os estados islâmicos estejam ativos no comércio internacional, dentro das negociações e cooperando para que se consiga um sistema não discriminativo de competição na política internacional.

A lei islâmica proíbe a fixação de preços no mercado e a prática do dumping é considerada interferência no livre mercado, que para os muçulmanos deve ser determinado pela compra e venda de produtos. Porém, é permitido para aos estados islâmicos participarem e fazerem uso de acordos anti-dumping para protegerem seus produtores domésticos e permitirem a busca da reparação, se seu mercado está sendo prejudicado por práticas não éticas de estrangeiros exportadores. Muitos países islâmicos têm feito uso do mecanismo anti-dumping da OMC para penalizar exportadores que têm tentado prejudicar seus mercados. ${ }^{406}$ Mas o sistema internacional é visto com reservas pelos economistas islâmicos. Em entrevista, o Professor Tavakoli argumenta:

"É uma espécie de torta, torta da economia, mas é uma espécie de bolo, ok? É o que dizem, se a torta era pequena, por isso, as fatias eram muito pequenas. Mas eles dizem que se deixar o bolo crescer, terão fatias maiores. Como em uma torta, essa ideia do bolo estará disposta a deixar outras pessoas terem acesso as fatias maiories? Isso é injusto. Eles dizem ok, aceitamos que a distribuição seja mais justa, mas há alguns

\footnotetext{
405 Essa proibição é baseada na proibição que o Profeta dá ao mercadores, que procuravam encontrar outros mercadores antes destes entrarem na cidade, para conseguir o preço melhor que o do mercado.

406 São apenas 4 estados islâmicos membros da OMC - Egito (38 casos), Indonésia (49 casos), Malásia (22 casos) e Turquia (53 casos). Todos têm reportado suas buscas por ações antidumping.
} 
benefícios para os pobres, para que eles tenham a sensação de ter mais, mas na realidade estão negligenciados a isso, a eficiencia e a justiça não estão pautadas nessa receita, e sim o quão grande as fatias de bolo podem ser, enquanto as fatias de torta permanecem pequenas."

O Islã procura promover o comércio em ambiente de mercado justo, cujos subsídios poderiam estar de acordo com um espírito contra a injustiça no mercado. ${ }^{407}$ Como os estados islâmicos estiveram sob o colonialismo e os instrumentos da lei islâmica foram deixados de lado, foram introduzidas novas leis e hoje seria necessário um novo preparo para a adaptação ao mercado. Dado o desejo político e o processo de aprendizado necessário será complexa a implementação da lei islâmica pelos países, ao que parece pouco ainda foi feito.

Quando analisamos historicamente, desde o século XIX governos tem sido uma força efetiva por trás da expansão colonial dos mercados para produtos industriais através de várias formas de interferência no mercado. Sempre foi proclamado e promovido um mercado livre, mas as potências econômicas sempre agiram de forma protecionista, praticando o lobby.

\subsection{Ordem Monetária no Islã}

Dinheiro é uma parte da expressão de uma cultura particular ${ }^{408}$, sua organização sócio-política e econômica, ou seja, o dinheiro de uma sociedade difere do de outra sociedade. Atividades nas quais o dinheiro é usado, tais como campanha militar, religião, política, jurídica, troca de mercado e comércio podem apenas ser compreendidas através da compreensão da cultura desta sociedade. O dinheiro revela a consciência das pessoas que o criaram. Um aspecto é o padrão do valor e representa significados e funções exclusivos desta comunidade e, por outro lado, é um meio universal de troca. ${ }^{409}$

A quantidade de dinheiro é normalmente expressa em valores designados divisíveis em moeda, ou seja, reais, dólares, libras etc. Esta é a quantidade nominal de dinheiro ou o montante de riqueza armazenado. Por outro lado, o real montante de dinheiro é a quantidade expressa em termos de volume de mercadorias e serviços que este

\footnotetext{
${ }^{407}$ Nas entrevistas, foram citadas formas de como o Profeta promovia a justiça no comércio, através de regras para a limitação e justiça na negociação.

${ }^{408}$ A moeda islâmica carregava a mensagem em uma forma de metalinguagem do Islã.

${ }^{409}$ REDDEN, Sitta von. Money, Law and Exchange: coinage in the Greek Pollis, IN: The Journal of Hellenic Studies, Vol. 117 1999, p. 154.
} 
pode comprar. O dinheiro metálico (ouro e prata) foi originalmente criação do mercado e foi criado também muito tempo antes da instituição do Estado moderno. Este dinheiro metálico tem sido capaz de manter uma proximidade na questão entre seu valor nominal e valor real por um longo período. Quando os metais preciosos eram usados como dinheiro, seu valor através da história permaneceu estável e confiável para as pessoas, por isso os muçulmanos, desde os tempos primitivos, cunham suas moedas de ouro e prata. $^{410}$

A moeda metálica e seus derivados são ativos que não podem ser manipulados facilmente, porém a moeda fiduciária e o crédito são tipos de dinheiro que podem ser facilmente adicionados em circulação. O sistema de moeda fiduciária tem sido associado com a rápida flutuação do nível dos preços, taxas de juros e a taxas de câmbio. Isto tem sido considerado um grande desafio para as instituições financeiras internacionais, instituições estas capitalistas estabelecidas para promover a estabilidade do mercado internacional. Através de medidas financeiras, elas não têm encontrado em si soluções efetivas, já que neste moderno sistema monetário é necessário que os países permaneçam devotados a um tipo de mecanismo de ajuste, o qual pode regular os valores do câmbio, criando assim maior confiança no sistema. Política e economia têm buscado uma forma de atender aos problemas da área, porém há grande dificuldade neste processo, não se conseguindo estabelecer um sistema justo em si.

Para o Islã, a natureza do sistema de moeda fiduciária está intimamente ligado a $r_{i b a w}^{411} i$ e gharar ${ }^{412}$ e seu papel no mercado internacional tem promovido outras práticas de riba e maysir (jogatina) através da especulação e a supressão econômica que tem feito esta circulação de moeda não ser compatível com a lei islâmica. Até mesmo grupos de economistas modernos têm advertido que o ouro e sua natureza mantêm uma moeda mais estável.

\footnotetext{
${ }^{410}$ KHALDUN, Ibn. Muqaddimah, Vol II, 1980, pp. 59 e 313.

${ }^{411}$ Que tenha qualquer elemento de usura.

${ }^{412}$ Gharar tem um conceito amplo que carrega diferentes formas em diferentes tipos de relações. Em um contrato de venda gharar sempre se refere a incerteza e ignorância de uma ou ambas as partes sobre as substância ou atributos do objeto da venda, ou a duvida sobre a existência no período de assinatura do contrato. Ou seja, esse conceito é usado nas transações no sentido de risco, incerteza ou dano. KAMALI, Muhammad H. Uncertainty and Risk-Taking (Gharar) in Islamic Law, IN: International islamic University Malaysia Law Journal, Vol. 7 nr. 2 1998, p.199-216.
} 
O dinheiro metálico, na forma de bronze e cobre produzido na China, no final da Idade da Pedra, foi considerado uma das primeiras formas de moeda de metal inventada pelo homem. É historicamente aceito que o mais valioso e aceitável dentre o dinheiro metálico é o ouro, a prata e o bronze. Por isso é amplamente reconhecido como um padrão de moeda através do período medieval. Existiram muitos tipos de moeda, cada uma com um tipo de design, peso, inscrições e a pureza do material também variava. A ascensão e o declínio dos impérios e a política dominante também foram afetadas pelo padrão monetário usado, como fica evidente pela transição do padrão persa nas várias sociedades gregas depois da queda de Atenas.

No período do Profeta, os muçulmanos usavam o dinar, a prata persa sigloi ${ }^{413}$, que os muçulmanos chamavam de dirham, ou metais puros ou outro tipo de mercadoria como dinheiro. Estes tipos de moeda eram aceitos em seu peso, porém não em seu valor. Alguns companheiros do Profeta costumavam fazer uma troca de dinheiro, trocavam ouro por prata por moedas em uso a taxas moderadas. Três tipos de metais eram usados nas transações econômicas: ouro (dinar), prata (dirham) e cobre (fals). A troca foi mais popular em vilas e pequenas cidades de agricultura. O hadith baniu as transações de troca que envolvia juros e isso indica sua prevalência nos tempos do profeta. Provavelmente, algumas das nomenclaturas das moedas árabes (dirham, dinar e fals) foram derivadas de palavras gregas e romana, as quais foram muito similares a estes nomes. ${ }^{414}$

Ibn Khaldun argumentava que Deus havia fornecido o ouro e a prata como um meio para a medida do custo e preço facilitando a permuta. ${ }^{415} \mathrm{O}$ ouro e a prata foram os melhores objetos a serem utilizados como dinheiro e no princípio do Islã, eles eram utilizados como um padrão bimetálico no mundo islâmico. No entanto, problemas começam a envolver o sistema monetário metálico quando estes fatores apareceram na sociedade internacional.

O declínio da competitividade econômica de um país resulta do gerenciamento pobre e de outras causas que estão fora do controle governamental, tais como desastres naturais e mudanças externas em eventos geopolíticos econômicos que podem negativamente afetar o padrão monetário. Condições nacionais econômicas ruins

\footnotetext{
${ }^{413}$ Veja VICKERS, Michael. Fifth Century Cronology and Coins Decree, 116 The Journal Hellenic Studies, 1996, p.172.

${ }^{414}$ A unidade básica de peso que foi relacionado a cunhagem através do mundo grego foi a "drachma" e prata drachma.

${ }^{415}$ Mukaddimah, Vol. II, pp. 59, 313 e Vol. III, p. 277.
} 
experimentadas pelos Estados têm também permitido que o preço do metal base flutue tremendamente, o que por sua vez, afeta o valor das moedas em circulação.

Esta situação econômica ruim leva à saída de metais preciosos, portanto reduzindo o suprimento de moedas. Muitos governos recorreram à depreciação ou à falsificação e nem sempre fugiram para o entesouramento, porém também mais para saída de metais preciosos, o que piorou o problema do suprimento de dinheiro. Esses preços tendem a ajustar-se automaticamente de acordo com o conteúdo metálico das moedas. O perigo do dinheiro abandonar o país sendo acumulado excessivamente em outro não aconteceria se cada país individualmente cuidasse dos balanços de suas contas correntes ou expandisse para um tamanho considerado impróprio face ao seu rendimento e riqueza.

Outro elemento importante que enfraquece as relações econômicas internacionais é quando o estado abraça uma abordagem nacionalista estreita para a economia e politica e dá procedência à rivalidade comercial ao invés da cooperação. ${ }^{416}$ De fato, poderíamos levantar aqui diversos problemas que assolaram o sistema monetário para a discussão do padrão ouro islâmico, ou dinar islâmico.

A história contemporânea do desejo de adoção deste modelo data da crise de 1997 ocorrida na Ásia, quando os especuladores de fato foram considerados responsáveis por parte dos problemas. Porém, é neste momento que a Malásia procurou convencer seus vizinhos a um movimento em direção à instalação do dinar islâmico.

\subsubsection{A Visão Islâmica do Papel Moeda e Dinheiro de Crédito}

$\mathrm{Na}$ Europa, muitos países usaram ambos, moedas de ouro e prata, porém permaneceu oficialmente o padrão prata ou o padrão bimetálico. Os muçulmanos, no entanto, permaneceram no padrão ouro até o colapso do último Império Islâmico, o Otomano. A quase aceitação universal do padrão ouro durante o último quarto do século (1870-1914) finalizou o sistema bi metálico.

O dinheiro moderno é puramente uma ficção econômica e legal, baseada não no que nós comumente entendemos como valor, mas sim no oposto, é baseado nada menos do que no débito. ${ }^{417}$ Tornou-se um conveniente substituto para o dinheiro real. De fato,

\footnotetext{
${ }^{416}$ Por exemplo, a rivalidade comercial do século XX.

${ }^{417}$ No mundo atual, no sistema fiduciário das finanças, a nota bancária em si é uma declaração legislativa e de garantia do governo em que se pagará uma demanda.
} 
dinheiro é um sistema contábil nacional e um sistema operado e possuído pela indústria bancária privada. ${ }^{418}$ Com a expansão das economias nacionais, tem sido gradualmente aumentado o crédito bancário de duas fontes, tanto dos Bancos Centrais quanto dos bancos privados e a emissão de crédito é um grande desafio para os estudiosos islâmicos, gerando grandes debates a respeito da legalidade deste sistema de valor.

As notas da moeda de governo, incluindo a dos países islâmicos, são aceitáveis somente como garantia constitucional de que a autoridade emissora irá aceitá-los como moeda legal. Essas moedas e notas criadas pelos governos são dinheiro criado sem custo, para além do material. Governos não têm necessidade particular destas moedas e notas e bancos são instituições que requerem o suprimento de dinheiro. O governo através da operação do Banco Central compra títulos e supre dinheiro, portanto, aumenta tanto os ativos quanto os passivos, consequentemente.

A questão a ser resolvida aqui é: qual a posição da moeda sob a lei islâmica? Para encontrar a justificação para sua permissibilidade sob a lei islâmica, primeiramente, podemos nos referir ao uso histórico suftaja $a^{419}$ ou $s a k k^{420}$ durante o período islâmico medieval. É evidente que a suftaja e sakk têm muitas características do papel moeda moderno. Ambos são portáteis e desenvolvidos da nota promissória.

No período medieval islâmico, o suftaja e sakk tornaram-se característica de todos os dias e eram um meio de troca amplamente utilizado, cobrindo locais como Sudão, Egito e Bagdá, Esfahan e Nova Délhi. Portanto, esta forma de moeda pode ser vista como um paradigma para o papel moeda, porém, em contraste com a moeda fiduciária, os suftajas foram considerados como um substituto para o ouro e a prata física, uma forma conversível de dinheiro. Assim, o papel moeda mantinha as características do precioso metal que representava. Eles são mesmos diferentes do recibo de compra, a venda e compra que é proibida pela lei islâmica. ${ }^{421}$

Uma segunda alternativa é olhar para a moderna moeda fiduciária como uma total invenção independente dos instrumentos monetários tradicionais do passado. No entanto, isto pode envolver alguma dificuldade por causa da evidência histórica de que é uma cadeia de desenvolvimento no dinheiro moderno: moeda fiduciária emergiu de dinheiro

\footnotetext{
${ }^{418}$ ANGEL, N. Regina. Preliminaries and Transitory Measures Toward a Complete Stabilization of the US Dollar, IN: International Journal of Social Economics, 1999, p.438.

${ }^{419}$ Letra de câmbio.

${ }^{420}$ Cheque.

${ }^{421}$ Malik's Muwatta, Livro 31, Nr 31:1944.
} 
conversível e o próprio dinheiro conversível surgiu de uma moeda mercadoria, que por sua vez surgiu da troca. A única diferença é que o link entre papel-moeda e dinheiro conversível marcou o ponto de partida da tendência do mercado natural.

O maior debate dentro do sistema se dará de fato no sistema moderno de criação da moeda fiduciária. Se for feito um escrutínio, este sistema será visto como uma fraude já que o que ocorre é o financiamento de um estilo de vida luxuoso que não cabe no sistema islâmico. Em entrevista no Irã, houve sempre uma persistência da ideia de um sistema bancário ou uma economia real. O Professor Ali-Asghar Hadavinia dá ênfase ao tema quando debatemos:

"O sistema bancário islâmico, não é baseado em suas crenças. É baseado na economia do contrato real, a economia real. Não o dinheiro mas a economia, a economia real. No sistema convencional você tem o sistema de empréstimo e de interesses. Este não é um tipo de economia real, é a base fundada em economia de mercado, mas no sistema bancário islâmico usamos as ferramentas de derivados para a economia comprando uma venda, aluguel, parceria etc. Assim, vemos todo o conteúdo a nossa base no tipo de economia real. No mercado de capitais, e não as crenças das pessoas. ",422

A ideia é de uma economia real que não adentre no sistema de financiamento de luxos e do ganho sem a efetividade do trabalho. Portanto, o sistema procurará se manter distante de boa parte das ideias e buscas do sistema capitalista. Esse moeda fiduciária criada pelos Bancos Centrais que são inconversíveis têm apoio de um poder de compra no futuro e, assim como as transações no Islã, é proibida porque envolve um grau de incerteza.

\subsection{Direcionamento Financeiro}

A parte mais conhecida do sistema islâmico econômico é seu sistema bancário que tem se expandido nos últimos anos, com um crescimento que tem sido considerado muito importante, um enfrentamento ao liberalismo segundo alguns pesquisadores do Islã. ${ }^{423}$ Quando falamos da banca islâmica, estamos falando do sistema bancário ou da

\footnotetext{
${ }^{422}$ As respostas à minha questão, foram traduzidas do farsi para o inglês, portanto por não haver uma terceira tradução, preferi manter a tradução do Professor Shahriyar Shojaeepour, que atuou como tradutor de minhas entrevistas.

${ }^{423}$ Nas entrevistas, era clara a questão de se desenvolver um sistema próprio no Islã. O estado islâmico deve ser visto de igual para igual aos outros estados. Então a questão do enfrentamento
} 
atividade bancária que é consistente com os princípios da lei islâmica e sua prática aplicação através do desenvolvimento da economia islâmica. A lei islâmica pró́be o pagamento de taxas para o empréstimo de dinheiro, assim como investir em mercadorias e serviços que estão contrários aos princípios islâmicos.

O sistema financeiro islâmico têm procurado atuar através do financiamento de capital que é melhor representado pelos contratos de parceria do tipo mudarabah e musharakah. A relutância do moderno sistema financeiro islâmico é provavelmente causado por algumas razões inter-relacionadas e, posteriormente, tornar o sistema financeiro islâmico baseado em financiamento de capital menos popular. A primeira razão, sem dúvida, é o alto risco a que ambas, mudarabah e musharakah, são expostas.

A mudarabah e a musharakah operam em uma base de participação nas perdas e lucros e são considerados ferramentas de alto risco porque o retorno ao Banco é mais incerto já que depende do desempenho do negócio e, nestas duas ferramentas de financiamento, os bancos devem também se comprometer com o risco do negócio.

Os bancos no Islã são empreendimentos conservadores e avessos ao risco por natureza, já que são responsáveis tanto para com os acionistas quanto para com os depositantes. Como seus depósitos compreendem pequenos e grandes valores, os bancos consideramse como administradores para estes fundos.

Outra razão por trás da relutância é a questão do risco moral. Naturalmente tanto a mudarabah quanto a musharakah requerem substancial confiança entre os bancos e seus clientes. O banco age somente como um provedor de capital como na mudarabah ou deixa todos os aspectos do gerenciamento para o cliente em termos de honestidade, integridade, gerenciamento e habilidade de negócios. Igualmente problemático é o aspecto de monitoramento e supervisão. Musharakah em particular requer mais comprometimento e esforço dos bancos comparado com outras formas de financiamento já que o banco assume os negócios assim como o risco de crédito. ${ }^{424}$

Esta inabilidade de garantir um penhor sobre os ativos dos parceiros de negócios poderia exigir uma avaliação mais cuidadosa das perspectivas dos negócios, portanto, mais precaução em ampliar os financiamentos. A partilha de riscos nos negócios também implica mais diligência em termos de pesquisa de mercado na companhia, nos negócios,

ao neoliberalismo e às imposições imperiais deve ser para o próprio cumprimento da lei islâmica e da chegada do Mahdi.

${ }^{424}$ Islamic Trade Export, 2012, p.101. 
competidores, indústrias e outros pelos bancos. E poderia o banco decidir participar ativamente no gerenciamento das empresas. $\mathrm{O}$ banco deve qualificar pessoal que tenha habilidades de gerenciamento para empreender estas tarefas. A maioria dos bancos são geralmente treinados para fazer análises de crédito, então não possuem treinamento na área gerencial necessária para proteger os interesses do banco no financiamento através da musharakah. ${ }^{425}$

Somando-se a esses problemas, talvez a questão da equiparação dos fundos poderia ser relevante para nossa discussão, já que a maior parte da fonte do banco é de depositantes de contas poupança ou contas correntes. A natureza de tais depósitos é que as retiradas são sob demanda. O prazo médio para um investimento em contas é de 24 meses, o que não é muito longo. No financiamento de mudarabah e musharakah, os bancos estão comprometendo seus fundos em empreendimento de médio a longo prazo e como resultado em incompatibilidade dos prazos das fontes (depositantes) e uso dos fundos. A maioria dos bancos islâmicos, sendo novos e inexperientes no mercado, não podem ocupar-se da musharakah como ainda não construíram todo seu grupo de acionistas e ainda é um longo período para se conseguir o efetivo retorno do financiamento em mudarabah e musharakah por ser uma instituição primeiramente preocupada com o lucro, principalmente no estágio de desenvolvimento.

Ainda relevante para este ponto da discussão é que a maioria dos bancos islâmicos foram inicialmente treinados como bancos convencionais e, com certeza, levará algum tempo para o banco adaptar sua maneira de ver o financiamento da perspectiva convencional para a perspectiva islâmica. Alguns pontos são extremamente importantes para os bancos islâmicos e a questão do retorno recebido e a agilidade deste retorno também deverão ser consideradas.

Os bancos islâmicos ainda enfrentam outro problema importante: a questão da estrutura do seu sistema de financiamento, à qual foi dada maior flexibilidade. ${ }^{426}$ Mas essa flexibilidade parece ainda não ser vista na prática, sendo que é possível perceber a complexidade do sistema, mesmo para os muçulmanos. Mesmo os bancos ainda parecem ter dúvidas do que eles podem e não podem fazer em musharakah e mudarabah. Há ainda certa relutância por parte dos clientes que preferem emprestar o dinheiro e dividir sua lucratividade com os bancos, vendo que seus projetos são muito atrativos.

\footnotetext{
${ }^{425}$ Idem, p.102.

${ }^{426}$ Islamic Banking Act, 1983.
} 
Os problemas apresentados aqui demonstram a questão de que os bancos necessitam de auxílio de especialistas na lei islâmica para superar os desafios que se apresentam no sistema financeiro, tornando a sistema mais atrativo e competitivo, de outra forma, os problemas permanecerão, fazendo com que o financiamento de capital permaneça impopular e impraticável, incapaz de competir com o sistema capitalista.

A respeito do dano moral e de sua relação com a garantia, o Islã crê que a garantia deve ser trazida no acordo do financiamento do projeto, particularmente para garantir o interesse do investidor, mas esta prática serve apenas para compensar qualquer negligencia cometida pelo empreendedor.

No Islã se trabalha com a ideia de um planejamento financeiro a partir da lei islâmica, que fornece a base necessária para a vida no muçulmano. Esse planejamento financeiro, em um sentido convencional, é um esforço para oferecer um serviço profissional aos indivíduos e suas famílias e também a seus negócios, uma assistência imparcial em analisar e organizar seus negócios com o intuito de conseguir atingir os propósitos financeiros e de estilo de vida.

O planejamento financeiro no Islã será permeado pela lei islâmica, ou seja, os valores e princípios deverão ser regidos pelo sistema financeiro islâmico, basicamente alguém que se encarrega em alguma forma de orçamento pessoal em termos de criação, acumulação e distribuição de riqueza, aqui no caso sempre focando a lei islâmica, dado que o planejamento financeiro tem como seus conceitos primários as crenças, trazendo uma base universalmente aceita na fundação do Laissez Faire. No caso do Islã, deve trazer a base de crenças que estão centradas na economia islâmica.

Tabela 1: Planejamento Islâmico Financeiro

\begin{tabular}{l|l|l|l} 
& Capitalismo & Islã & Socialismo \\
\hline Conceitos Genéricos & Conceitos Primários & Conceitos Primários & Conceitos Primários \\
\hline Riqueza e Recursos & Escassez de recursos & $\begin{array}{l}\text { Graça de Deus e } \\
\text { nenhuma escassez }\end{array}$ & Escassez de recursos \\
\hline $\begin{array}{l}\text { Propriedade } \\
\text { Privada }\end{array}$ & Liberdade individual & $\begin{array}{l}\text { Uma relação de } \\
\text { confiança }\end{array}$ & $\begin{array}{l}\text { A fonte de exploração do } \\
\text { trabalho }\end{array}$ \\
\hline $\begin{array}{l}\text { Objetivos do } \\
\text { Estilo de Vida }\end{array}$ & $\begin{array}{l}\text { Satisfação Pessoal } \\
\text { (necessidades e } \\
\text { desejos) }\end{array}$ & Falaah (Prosperidade) & $\begin{array}{l}\text { Igualdade de bem estar no } \\
\text { seio do proletariado }\end{array}$ \\
\hline
\end{tabular}


Consequentemente, no nível operacional, estes conceitos islâmicos devem ser trazidos em cada estágio da criação, acumulação, proteção e distribuição de riqueza, pois cada atividade do homem é considerada um ato de adoração a Deus. ${ }^{427}$ Portanto, o planejamento financeiro islâmico deve estar de acordo com a lei islâmica, sendo que deve haver a compreensão de que os muçulmanos não têm outra opção, ou seja, devem seguir o planejamento e o uso dos produtos islâmicos.

No Islã, a riqueza é considerada uma benção de Deus, portanto não é algo escasso. ${ }^{428} \mathrm{O}$ que é escasso é a habilidade da humanidade em utilizar ou explorar as benção de Deus. Com respeito à propriedade privada, o Islã a considera como uma relação de confiança com Deus, sendo que serão cobrados por esta responsabilidade. Finalmente, o estilo de vida dos muçulmanos não deve ser focado em uma satisfação temporária das necessidades e desejos, mas sim na busca de atingir o falaah ou a prosperidade que leva a uma boa vida aqui e na vida pós a morte.

\subsubsection{Crédito Bancário}

$\mathrm{Na}$ história do sistema bancário, descobrimos que os bancos privados imprimem e circulam suas próprias notas bancárias para financiar o sistema industrial. Portanto, o sistema do dinheiro metálico foi expandido e, devido à facilidade de suprimento do crédito, a inflação-deflação gerada acabou gerando preocupações. Mais tarde, os bancos privados foram proibidos de emitir notas bancárias e criaram os depósitos bancários, emprestando da mesma forma instável. Esse financiamento foi feito de diversas formas, empréstimos, cartão de crédito e a criação de dinheiro eletrônico. Mudanças na quantidade de dinheiro no mercado originam muitas ações do Banco Central, vindas das instituições de depósitos privadas ou públicas, sendo maior influência, no entanto, a política monetária do Banco Central. Esse crédito bancário sofre problema devido à regulamentação, algo claramente perceptível pela crise de 2008.

427 “(Recorda-te, ó Profeta) de quando teu Senhor disse aos anjos: Vou instituir um legatário na terra! Perguntaram-lhe: Estabelecerás nela quem ali fará corrupção, derramando sangue, enquanto nós celebramos Teus louvores, glorificando-Te? Disse (o Senhor): Eu sei o que vós ignorais. “ (Corão 2:30); "Não criei os gênios e os humanos, senão para Me adorarem." (Corão 50:56) 428 "A vida terrena é tão-somente jogo e diversão. Porém, se crerdes e fordes tementes, Deus vos concederá as vossas recompensas, sem vos exigir nada dos vossos bens.” (Corão 47:38) 
A função de criação de dinheiro dos bancos privados e outras instituições financeiras está sujeita à regulamentação governamental, no entanto, este amplo poder constitucional tem resultado na delegação de grande poder de criar (virtualmente) dinheiro no sistema bancário, poder este que o próprio sistema legislativo não tem. Em muitos países, a habilidade do banco de produzir o crédito não é regulado, mas repousa sobre os seus requisitos da prudente economia, opção política e de reserva e é agravada pela desregulamentação da indústria bancária.

Toda essa situação pode ser explicada pelo relacionamento entre os financiadores e os políticos e os interesses de alguns grupos, que tornam esta prática tolerável, e sua realidade de certa forma está fora do escrutínio da maioria da população que é afetada por estas decisões. Esse poder arbitrário está contra os princípios de confiança, prestação de contas e justiça da lei islâmica. ${ }^{429}$ De fato, ao contrário, a lei islâmica impõe a responsabilidade no governo em proteger os cidadãos de tal manipulação do mercado através da instituição da hisbah.

Atualmente a lei islâmica tem dificuldade em lidar com o sistema internacional, impondo regras para o financiamento e a criação de crédito sobre crédito. $\mathrm{Na}$ lei, são colocadas certas restrições que discutimos no capítulo anterior. Sob a lei islâmica, um débito representa uma commoditie como o ouro, prata ou alimento e não pode ser comprada ou vendida no sentido de que a lei tem fechado a porta para que um débito não se torne um meio de troca.

Os estudiosos da lei islâmica procuram dificultar um sistema no qual possa haver inflação ou especulação, que é considerada o equivalente da jogatina. No Islã, tradicionalmente risco significa a possibilidade de sofrer com o perigo ou dano, sendo considerado um elemento da vida neste mundo, ignorante sobre o futuro. É também um

429 "Ó Davi, em verdade, designamos-te como legatário na terra, Julga, pois entre os humanos com equidade e não te entregues à concupiscência, para que não te desvies da senda de Deus! Sabei que aqueles que se desviam da senda de Deus sofrerão um severo castigo, por terem esquecido o Dia da Rendição de Contas."(Corão 38:26); "Deus manda restituir a seu dono o que vos está confiado; quando julgardes vossos semelhantes, fazei-o equidade. Quão excelente é isso a que Deus vos exorta! Ele é Oniouvinte, Onividente."(Corão 4:58); “E preveni-vos contra a intriga, a qual não atingirá apenas os iníquos dentre vós; sabei que Deus é Severíssimo no castigo."(Corão 8:25); "Combatei-os até terminar a intriga, e prevalecer totalmente a religião de Deus. Porém, se se retratarem, saibam que Deus bem vê tudo o quanto fazem." (Corão 8:39); "Disseram: A Deus nos encomendamos! Ó Senhor nosso, não permitas que fiquemos afeitos à fúria dos iníquos;"(Corão 10:85); “Crede em Deus e em Seu Mensageiro, e fazei caridade daquilo que Ele vos fez herdar. E aqueles que, dentre vós, crerem e fizerem caridade, obterão uma grande recompensa." (Corão 59:7) 
fator de investimento que uma pessoa precisa de tempo para compreender quando selecionar os instrumentos de investimento. Para muitos muçulmanos, o futuro está nas mãos de Deus, em que estes estão colocando suas vidas, sendo ricos ou pobres, alegres ou felizes, tudo está centralizado nas mãos de Deus. Mesmo sabendo que está nas mãos de Deus, o muçulmano é incentivado a ter um bom comportamento, pois isso terá um retorno positivo levando a paz e contentamento. Porém, ainda sim deve fazer todo o esforço possível para evitar a calamidade e má sorte.

O Corão apresenta histórias de outros profetas, assim os muçulmanos aprendem lições destas experiências. ${ }^{430} \mathrm{~A}$ história do Profeta traz exemplos para os muçulmanos de como gerenciar os riscos. Um dos exemplos é que, quando o Profeta inicia sua missão de sua casa, inicia a ensinar os de sua casa, as pessoas mais próximas, reduzindo assim os riscos de rejeição. O Profeta também procurou se encontrar e ensinar os novos convertidos, em privacidade, porque o chamado ainda estava no início e deveria ser ensinado individualmente. Outro exemplo citado é sobre a mudança do Profeta para Medina. Com o intuito de reduzir o risco de ser morto, o Profeta pede para Ali dormir em sua cama durante a noite de emigração. ${ }^{431}$

Da mesma forma, o Islã criou um sistema para eliminar o risco no sistema financeiro. Takaful é uma forma de reduzir o risco financeiro de perda devido a acidentes e infortúnio. Tem sido definido como um esquema baseado em assistência mútua, que prevê uma ajuda financeira e assistência aos participantes em caso de necessidade, com os participantes mutuamente concordando em contribuir ao propósito. ${ }^{432}$ Portanto, é uma transação financeira de cooperação mútua entre duas partes para proteger uma delas de risco material futuro inesperado.

Em realidade, takaful é um plano alternativo para o seguro do sistema financeiro convencional. No plano takaful, o participante poderia pagar um montante particular de dinheiro como contribuição (conhecido como prêmio) parcialmente a arriscar o fundo (as contas especiais dos participantes) usando o conceito de tabbaru' (doação) em parte. A outra parte (conhecida como empresa de takaful) com um acordo mútuo que o kafiil está

\footnotetext{
430 "Depois disse: Ó filhos meus, não entreis (na cidade) por uma só porta; outrossim, entrai por portas distintas; porém, sabei que nada poderei fazer por vós contra os desígnios de Deus, porque o juízo é só d’Ele. A Ele me encomendo, e que a Ele se encomendem os que (n’Ele) confiam."(Corão 12:67)

${ }^{431}$ É relatado que a tribo postou assassinos que vigiaram durante toda a noite, vigiando e esperando para matá-lo na manhã, olhavam pela porta e ainda o viam na cama.

${ }^{432}$ Islamic Trade and Commerce, 2012, p.108.
} 
sob a responsabilidade legal de fornecer aos participantes uma proteção financeira contra uma perda inesperada, que pode ocorrer dentro de um período determinado. No entanto, no caso de perda, não ocorre aos participantes dentro de um período especifico, os participantes têm direito de todo o montante do prêmio pago, junto com a parte do lucro acumulado com base no prêmio no princípio da técnica financeira Mudharabah. ${ }^{433}$

\subsubsection{Comércio Internacional e Câmbio}

A monetização do comércio internacional toma lugar através do mercado de câmbio. Quando uma pessoa de um país requer produtos de firmas de outro país, eles precisam ir ao mercado e comprar a moeda corrente de este outro país. A taxa de cotação do câmbio internacional é diferente para cada país que existe no mundo, porque a mudança constante no suprimento e demanda por moeda estrangeira resulta na mudança dos preços da moeda.

Sob o padrão ouro, o valor de todas as moedas eram fixados em termos de quanto ouro pode ser trocado por aquela moeda em particular. O sistema se tornou efetivo quando os estados mantinham suficiente montante de ouro em suas reservas em seus países. No sistema metálico estável, a organização da estrutura de trocas era facilitada através do mercado sem a necessidade de intervenção dos estados, mas neste sistema atual a intervenção se tornou indispensável para o efetivo funcionamento.

Quando o padrão ouro foi abolido, o mercado cambial tornou-se relativamente importante no quesito do troca monetária ${ }^{434}$ e tornou-se um sistema que se mantinha em uma flutuação dependendo de índices de mercado. ${ }^{435}$ A moeda de um país não é nem de

\footnotetext{
${ }^{433}$ Muḍārbat é explicada como um contrato entre duas partes, quem providencia o capital (participante neste caso) e o empreendedor (conhecido como a empresa de takaful) que fornece as habilidades do negócio. Os lucros são divididos entre as duas partes.

${ }^{434}$ Opções de ganho como no sistema de triangulação, pois em tese as taxas de compra a venda de moedas praticadas em vários mercados de câmbio deveriam corresponder umas às outras. $\mathrm{Na}$ prática, porém, verifica-se que certas moedas podem apresentar diferenças de preços em determinadas praças e em determinados momentos. Esse cenário é responsável pelo fenômeno de arbitragem, a situação na qual os agentes obtêm lucros aproveitando as diferenças de preço de uma moeda, quando é negociada em dois ou, mas mercados. Aqui mostra como um especulador do mercado pode faturar milhões. Essas opções de arbitragem acontecem em outros mercados que não o de câmbio, por exemplo, o de trading commodities, títulos e ações, sendo classificadas como operações de enormes riscos. CARVALHO, G. Introdução às finanças internacionais. São Paulo: Pearson, 2007, p. 27.

${ }^{435}$ De fato, todos os países possuem um "medo de flutuar" e hoje já se defende de que as intervenções do governo não funcionam.
} 
longe comparada com o padrão ouro para o sistema internacional, além de criar um sistema de competição e não colaboração entre os países. Além de não haver uma estabilidade de preços, o sistema se apresenta volátil gerando problemas para os países de periferia.

\subsubsection{Necessidade de um Sistema Monetário Justo}

Desde o colapso do sistema Bretton Woods, o sistema monetário internacional tem visto uma série de turbulências econômicas e desacelerações que severamente afetaram a vida de bilhões de pessoas. Tudo isso pode ser traçado na base da economia, sendo que as flutuações podem ter um impacto dramático na performance dos negócios internacionais por afetar o preço relativo de produtos domésticos e mercadorias estrangeiras. Temos aqui uma rede complexa desequilibrada, que causa males à economia dos países. Com esta rede intrincada entre as finanças, os empresários e trabalhadores, negociantes e governantes que acabam por tolerar o sistema bancário, a especulação e distribuição desigual de lucros. Todos estes entre outros fatores têm levando o sistema a uma instabilidade das condições econômicas e preços, levando a males sociais..

Para solução destes males, a solução prática é vista com a construção de um sistema monetário padronizado e estável imitando os sistemas clássicos, avaliando as causas que levaram aos problemas, procurando assim adequar e trazer um equilíbrio à economia de mercado atual. O uso e uma commoditie estável é visto como a melhor solução para promover o sistema que o estado islâmico busca.

\subsubsection{Monopólio do dinheiro e o liberalismo}

Como um problema econômico, o dinheiro se torna uma das áreas mais antigas sujeitas à regulamentação governamental e a razão para isso é nobre. O governo tem um papel natural em facilitar a operação previsível, uniforme, justa e econômica do sistema de trocas. Embora, historicamente, a maioria dos sistemas de pagamentos tenha emergido da prática comercial, legislações governamentais têm sido decretadas para padronizar tais procedimentos e reformar os aspectos do sistema que podem ser vulneráveis à desorganização relativa dos grupos de usuários afetados. 
No entanto, quando governo monopoliza a emissão de dinheiro e vai contra o desejo do mercado escolher os meios de troca, isso vai contra o conceito de mercado livre. O mercado é complemento do desenvolvimento das civilizações islâmicas e ocidental e um mercado justo e eficiente é a chave para atingir uma ordem monetária justa. Por isso há propostas de acabar completamente com o monopólio do governo em suprir dinheiro e permitir empresa à privada suprir com meios de troca que ela pode preferir.

A maioria dos governos hoje monopoliza a emissão de papel moeda e esse monopólio significa que os cidadãos são obrigados a utilizar essa moeda, mesmo que achem insatisfatório o sistema. Isso previne o uso de métodos alternativos como meio de troca, revertendo a tendência de minimizar o papel do estado como um compromisso econômico liberal.

O monopólio do dinheiro pelo estado, de fato, é uma falácia da imaginação neoliberal que visualiza que o Estado e o mercado podem somente existir em oposição a cada um. Por outro lado, como um paradoxo para isto, os países em desenvolvimento estão colocando pressão em países em desenvolvimento para rapidamente liberarem o sistema financeiro através Organização Mundial do Comércio no Acordo de Comércio e Serviços.

\subsubsection{Interferência no mercado}

A adoção de moedas que necessitam de sistema de taxa de câmbio flexível tem desestabilizado o valor da moeda e encorajado a especulação, deste modo aumentando a chance de uma intervenção oficial no mercado de câmbio internacional. Nações têm intervindo no mercado de câmbio internacional não apenas para suavizar o movimento diário, porém também para afastar tendências especulativas, e manter as taxas de câmbio manipuladas dentro das zonas de alvo para encontrar o que é supostamente de interesse nacional. A intervenção no mercado de troca internacional é um risco dos negócios e sua efetividade é muito limitada, particularmente para países em desenvolvimento com baixa credibilidade do banco central e com uma posição de liquidez externa fraca. A intervenção pode frequentemente ser muito custosa e falhar em atingir o resultado desejado.

A regulamentação da conduta da economia doméstica tem sido influenciada até certo ponto pelo diálogo sobre a justiça, filosofia e ética. O poder político escolhe regular 
a conduta na economia internacional por dar prioridades para seus fins políticos e econômicos. Como a liberalização interna e externa em todo o mundo é realidade, moedas nacionais têm sido expostas à competição internacional e têm que lutar pela sobrevivência. A moeda de um Estado, que desfruta de um status de moeda internacional, tende a ter financiamento e vantagens mercadológicas, na provisão de reserva de moedas, empréstimo em moeda estrangeira, patrimônio da dívida e refinanciamento de resseguros no mercado financeiro.

Por décadas, o padrão de vida americano tem sido artificialmente aumentado através da entronização do dólar como uma reserva da moeda mundial. Trilhões de dólares são criados eletronicamente no exterior sem qualquer custo de responsabilidade devida para a economia americana.

O problema de débito enfrentado pelos países desenvolvidos e os países membros da Organização Mundial do Comércio, particularmente a África subsaariana, constitui um sério obstáculo aos esforços de desenvolvimento e crescimento para estes países, que estão ligados a um círculo vicioso de pobreza, crescimento das tensões sociais e instabilidade política.

A crise que enfrentamos começa com uma diminuição acentuada do valor nominal da moeda, ${ }^{436}$ resultando em uma contradição significante da saída da economia, crescimento do desemprego e um colapso nos bancos. Os incidentes dos anos 80 e 90 já identificavam as fraquezas do sistema econômico e suas causas e que poderiam se instalar crises, mas o desejo do capital de sempre ampliar cada vez mais sua lucratividade leva a decisões levianas.

$\mathrm{Na}$ história econômica do século $\mathrm{XX}$, temos diversos períodos que fornecem informações a respeito das fraquezas do setor financeiro, porém parece que os economistas têm ignorado a experiência da história. Muitos abordam como fraqueza a questão do sistema financeiro usando o conceito do perigo moral, ou seja, que os atores econômicos possuem um escudo contra as consequências de suas ações imprudentes, já que os governos sempre os ajudam resgatando suas empresas, assim como ocorreu na crise de 2008.

\footnotetext{
${ }^{436}$ Estamos abordando aqui a Crise Americana do Subprime que inicia uma cadeia de crises nos países Europeus e depois nos países parte dos BRICs que de fato parecem crises menores, mas muitas vezes nos levam a uma interpretação de que o sistema capitalista necessita de uma mudança de estrutura, pois as mudanças políticas econômicas não trazem resultados.
} 
O que de fato demanda maior atenção é que cidadãos inocentes, literalmente milhões deles, que não têm parte nesse excesso especulativo, pagam por estas crises financeiras. O sistema atual falha em proteger os mais necessitados, mostrando a razão de uma reforma.

No passado, a competição entre uma moeda forte tem mostrado que uma moeda mais fraca vai se tornando cada vez mais fraca até que é trocada. ${ }^{437} \mathrm{O}$ sucesso da integração europeia criou a crença de que uma nova moeda europeia, o euro, poderia facilmente assumir o papel de reserva monetária e talvez substituir o dólar, porém os recentes acontecimentos têm demonstrado a dificuldade de se manter a integração e a força da moeda.

O que temos presenciado é um montante considerável de bilhões de dólares circulando no exterior e mais trilhões circulando virtualmente gerando grande especulação sobre o sistema, causando hiperinflação. Indiretamente, muitas vezes isso reduz poder de compra nos mercados mais fracos. Quando analisamos cuidadosamente o sistema, parece estar em desordem. Por isso é trazida à tona a busca pelo padrão ouro no sistema islâmico, ou seja, um temor do crescimento deste sistema americano descontrolado.

\subsection{Benefícios e Desvantagens do Padrão Ouro}

O ouro tem um valor intrínseco e para o homem isso se reflete na função de sua gratificação física característica e sua escassez. Se não é usado como um meio de troca, ele pode ser usado para outros propósitos. Em oposição ao sistema atual, o Islã busca a criação de um sistema similar ao padrão-ouro utilizado em décadas anteriores, pois crê que este sistema equilibra a riqueza devida a todas as nações. A razão pela qual o ouro tem sido a escolha em vários períodos da história do homem, é pela função que ele pode representar dentro do sistema. No Islã, se acredita que um padrão ouro pode trazer a estabilidade do sistema internacional.

Por usar um peso fixo de ouro como um padrão monetário, seria dado à moeda um valor intrínseco. Assim, a sua taxa de câmbio em relação a outras moedas de caráter

\footnotetext{
${ }^{437}$ No passado, depois do padrão-ouro, a libra esterlina serviu como a moeda de reserva internacional. Depois da Segunda Guerra Mundial, um novo sistema financeiro internacional foi estabelecido sob a supervisão das instituições do Bretton Woods, e o dólar americano substituiu a libra esterlina.
} 
semelhante. Um padrão tão confiável e objetivo de valor necessita de uma importação e exportação de ouro livre, de modo que uma taxa de câmbio fixa torna-se um meio equitativo de pagamento que levará à estabilidade monetária, financeira e econômica. Para o Islã, é necessário que haja uma instituição internacional que possa regular e coordenar as relações dentro do sistema monetário internacional. Somente com o padrão ouro e uma maior estabilidade do sistema, poderia este ser livre de intervenções. Um padrão ouro moderno poderá ser autorregulado e assim não será manipulado por alguns governos como ocorre atualmente.

Por seu valor intrínseco, o ouro torna-se um meio de troca que pode garantir a estabilidade. Assim, o risco do câmbio será evitado nas transações internacionais entre vários países. Com uma ampla aceitação, a taxa de troca pode promover um boom no mercado internacional sem prejudicar as economias menos favorecidas.

Se o padrão ouro for reestabelecido, os governos e os bancos centrais não serão capazes de converter notas excessivamente. Será necessário assim que os países sejam disciplinados em manter uma paridade razoável entre o que eles emitem em termos de notas bancárias e reservas de ouro. Portabilidade e anonimato do ouro são importantes, mas o fato mais importante é que o ouro é um ativo que é de responsabilidade de mais ninguém. Todas as formas de ativos de papel, títulos, ações de e até mesmo os depósitos bancários são promessas para pagar o dinheiro emprestado.

Outra defesa relatada como uma vantagem do padrão ouro é a habilidade de restaurar e manter a estabilidade dos preços. Se o dinheiro é restringido pelo ouro, a economia não pode inflar arbitrariamente, assim os preços ficam estabilizados.

É claro que não há apenas relatos sobre vantagens do sistema de padrão ouro. Muitos argumentam que somente o ouro não seria suficiente para promover a liquidez internacional necessária com um crescimento do comércio exterior. Estes com certeza se referem ao alto preço do ouro, mas não significa o seu valor real, mas sim artificial criado pelo sistema, mas não se sabe ao certo, se mesmo com um sistema monetário estável, a nova produção de ouro seria suficiente.

Outro ponto a se repensar é que os países islâmicos não possuem uma grande reserva de ouro, porém Friedman ${ }^{438}$ sugere que, baseado na prática, teoria e razões históricas, um sistema bimetálico poderia ser adotado, mas a ideia é adotar o bimetalismo

${ }^{438}$ FRIEDMAN, M. Bimetalism Revisited, op. cit. p. 95-96. 
como forma de se manter um sistema financeiro saudável, para se ter um valor de moeda independente dos poderes governamentais, protegendo assim uma população mais pobre.

\subsubsection{Uso do Padrão Ouro na Atualidade}

Desde o colapso do sistema Bretton Woods em 1971, a nenhum país no mundo tem sido permitido voltar à sua moeda, a nenhum outro sistema além do permitido pelo Fundo Monetário Internacional. ${ }^{439}$ Os países islâmicos têm incorporado esta obrigação em suas legislações domésticas, com o intuito de se adaptar à economia mundial. ${ }^{440}$

O FMI busca promover seu sistema monetário preferido impondo restrições contra o uso de esquemas alternativos. Os estados podem adotar livremente sua própria forma de organização para o câmbio, menos o ouro, abolindo o preço oficial do ouro. Hoje também estão autorizados a exercerem uma supervisão sobre o gerenciamento das taxas de câmbio dos países membros. De fato, qualquer tentativa de retorno a uma base no ouro é uma rebelião contra o FMI, é evidentemente não favorável à sua política. Aqui reside uma questão importante para se refletir, já que o FMI legaliza outros tipos de dinheiro, menos o ouro.

Os Estados devem adotar um padrão ouro nas suas transações domésticas e nas transações internacionais, ou se usarem domesticamente o ouro para fazer pagamentos internacionais, o papel moeda deve ser trocado pelo preço do ouro e vice-versa. Ou seja, o ouro continua sendo a referência padrão. Para o Islã, o uso do ouro como um regime de base monetária é consistente com a filosofia do livre mercado. No sistema do laissez-faire capitalista assim como na filosofia mercadológica islâmica, a liberdade econômica e a propriedade privada são um direito do homem. Contanto que a lei dos outros - da comunidade e de Deus - seja respeitada, a pessoa pode fazer o que deseja e o papel do governo se limita em proteger as pessoas, as propriedades e a santidade da religião através

\footnotetext{
${ }^{439}$ Sigla que utilizaremos é FMI. Uma organização internacional criada em 1944 na Conferência de Bretton Woods (formalmente criada em 27 de dezembro de 1945 por 29 países-membros e homologado pela ONU em abril de 1964) com o objetivo, inicial, de ajudar na reconstrução do sistema monetário internacional no período pós-Segunda Guerra Mundial. Os países contribuem com dinheiro para o fundo através de um sistema de quotas a partir das quais os membros com desequilíbrios de pagamento podem pedir fundos emprestados temporariamente. Através desta e outras atividades, tais como a vigilância das economias dos seus membros e a demanda por políticas de auto-correção, o FMI trabalha para melhorar as economias dos países.

${ }^{440}$ Os bancos no Egito não estão autorizados a especular em metais preciosos e a Jordânia só pode vender e comprar ouro com propósito de investimento.
} 
do sistema legal e a politica de mercado. ${ }^{441}$ As pessoas são livres dentro do espectro da lei islâmica.

O padrão ouro ou metálico é o único arranjo financeiro compatível com a visão islâmica, que considera a questão da historicidade importante neste aspecto. ${ }^{442}$ Atualmente voltar ao ouro depende basicamente da liderança americana no sistema, ${ }^{443}$ algo que o país rejeita veementemente. Hoje, poucos economistas e políticos defendem a volta do padrão ouro, já que não há realmente como controlar essa geração de riqueza virtual criada pelo sistema e seria muito difícil manter as políticas monetárias para atender aos objetivos econômicos.

\subsection{Dinar Como Experiência Islâmica}

Os muçulmanos adotaram o dinar como uma meio de troca. $\mathrm{O}$ dinar em ouro permaneceu como uma moeda oficial islâmica até o colapso do Império Otomano em 1924. No Islã, o ouro é prescrito como uma forma de dinheiro, mesmo que esteja restringido pelas circunstâncias internacionais, a lei islâmica demanda que se use o ouro.

No passado, os muçulmanos não estavam em posição de atuar em um papel ativo na deliberação e no estabelecimento de um sistema monetário e financeiro e isso contribuiu para que o sistema que se possui hoje muitas vezes colida com a lei islâmica. Com a independência e com a experiência do desenvolvimento, ocorreu certo grau de auto respeito entre os próprios muçulmanos e o desejo de restaurar o sistema antigo.

Com seu desenvolvimento, o mundo muçulmano passou a olhar para sua vida econômica e social de acordo com a lei islâmica e depois de perceber o efeito antiético dos aspectos do sistema monetário na lei islâmica, os muçulmanos têm feito esforços para corrigir o desalinhamento que existe.

O Islã defende que o sistema atual deve ser mudado cautelosamente, tendo em perspectiva a coexistência das culturas e crenças. Considerando o cenário econômico e politico da atualidade o Islã reconhece que não é possível retorno ao padrão ouro. A

\footnotetext{
${ }^{441}$ Aqui cabe a instituição da Hisbah.

${ }^{442} \mathrm{O}$ argumento é que quando foi possível para o homem escolher o sistema monetário, ele sempre escolheu o ouro e a prata, devido ao alto valor e admiração por este objeto. Walter Block, p.15 ${ }^{443} \mathrm{O}$ abandono do padrão ouro ocorreu em 1971 e assim outras nações também o abandonaram. Com isso, o dólar passou a ser a moeda de referência.
} 
globalização, como processo muito complexo ${ }^{444}$, oferecerá resistência tanto dentro dos países quanto no sistema internacional. Encontrar uma solução dentro da lei islâmica de forma imediata tem se mostrado complicado, ainda mais dentro de um sistema monetário e financeiro complexo.

No entanto, o Islã obriga os muçulmanos primeiramente a trabalharem entre si na busca de uma solução para o sistema monetário. ${ }^{445}$ Enquanto se busca uma solução para adequar as leis islâmicas ao sistema internacional, deve-se permitir, mesmo que temporariamente, a troca cambial e vendas a prazo. Condições impostas pela moderna economia pedem uma solução não apenas legal, porém, ao mesmo tempo devido ao elemento emergência, devem ser feitas transações que são vitais para a economia islâmica contemporânea, até que se encontrem alternativas viáveis para os problemas encontrados. Além do mais, a política é um aspecto importante da lei islâmica e deve ser um elemento adicional empregado pelo pensamento islâmico econômico na deliberação realizada pelos Ulemas para a solução dos problemas da sociedade islâmica.

Enquanto uma reforma deve ser empreendida, deverá ser realizada gradualmente. A cooperação com outras organizações dentro e fora do mundo islâmico pode contribuir para o desenvolvimento da ideia da volta de um padrão ouro, ou pelo menos do dinar islâmico. Para essa questão, sabe-se que é necessária a compreensão do sistema, a criação de uma legislação adequada e para isso todo um processo de burocracia. A ideia a princípio é que se empreenda este sistema entre os países islâmicos e quando se estabelecer com força o sistema, que este possa ser expandido a outros países.

Não podemos negar que com o passar dos anos, o Estado tem de fato tomado o controle do sistema que era dado ao padrão ouro, ou seja, o sistema pode funcionar precisamente como uma alternativa viável, ou uma política pública para um sistema monetário mais competitivo. Para ser bem sucedido, o projeto do dinar islâmico deve ser claro em seus objetivos em termos de metas e prerrogativas. A busca é por um melhor

\footnotetext{
${ }^{444}$ Usamos como base para compreender a globalização Milton Santos, partindo de que a imposição de um sistema de globalização do capitalismo ocorreu a principio como uma forma nefasta e destruidora e hoje o Oriente Médio sofre diversos desastres humanos devido a isso.

445 "Os fiéis que migraram e sacrificaram seus bens e pessoas pela causa de Deus, assim como aqueles que os ampararam e os secundaram, são protetores uns aos outros. Quanto aos fiéis que não migraram, não vos tocará protegê-los, até que o façam. Mas se vos pedirem socorro, em nome da religião, estareis obrigados a prestá-lo, salvo se for contra povos com quem tenhais um tratado; sabei que Deus bem vê tudo quanto fazeis." (Corão 8:73)
} 
balanço de pagamentos, acordos de comércio e financeiro, pois o câmbio incorre em muitos riscos e é considerado haram por estudiosos.

O desenvolvimento do dinar não eliminará o uso do papel moeda, um Banco Central deverá emitir uma moeda cunhada de ouro e prata, não eliminando também o uso da tecnologia, mas tornando o sistema eficiente. Outro ponto importante é que no período de transição do papel-moeda para o sistema metálico haverá dois tipos de moedas competindo uma com a outra, mas isso não necessariamente elimina o crescimento do dinar islâmico.

O Islã tenta minimizar, de todas as maneiras, as tentações de usar métodos de aquisição de riquezas ilegais através do comércio, riba, especulação e outros comportamentos antimercado. A este respeito, o Profeta não somente desaprovou certas formas de negócios, mas também descreveu certos elementos que podem ser preenchidos em cada transação para que esta esteja dentro da lei.

O capitalismo moderno não apresenta um sistema de justiça social e equidade na produção e distribuição da riqueza. Está exposto à tendência de concentração de desigualdade na economia e ao poder financeiro nas mãos de algumas pessoas e instituições, prática de estratégias de mercado ou administração de preços ao custo de uma grande massa de consumidores e é incrível que nem as cortes de justiça nem os representantes das pessoas estão protestando contra estas práticas nocivas. De fato, as leis monetárias e financeiras na economia capitalista são construídas para proteger o método desequilibrado da formação do capital. Em nível mundial, um conluio entre as instituições financeiras internacionais e as organizações privadas, com sua fiscalização econômica e financeira e controle global acaba se tornando um ditador em sentido econômico e impondo um sistema perigoso.

\subsection{2 Áreas de Livre Comércio e Cooperação Internacional no Islã}

A ascensão da civilização islâmica contribuiu para o desenvolvimento econômico e para a teoria econômica, mas sua ascensão no final do século XX é parte da reação contra o socialismo árabe, que para os muçulmanos destruiu os mercados no mundo islâmico. Essa rejeição ao secularismo e ao socialismo veio de mãos dadas e de fato não surpreendeu. Há certa declaração de que não se pode ser muçulmano e se opor à liberdade de empresa. 
A oposição ao livre mercado pode vir de várias direções, pode vir de raízes ideológicas como a objeção à propriedade privada (socialismo), um desdém pela prosperidade material em si (asceticismo), uma antipatia às variedades de riqueza que acompanham o mecanismo de mercado (igualitarismo econômico) ou uma crença de que uma economia de comando pode prover melhores benefícios (autoritarismo). Mas o Islã se recusa a aceitar qualquer destes pontos descritos.

Em contraste com o socialismo, o Islã defende a propriedade privada como algo sagrado. ${ }^{446}$ De fato, este conceito de propriedade privada já estava bem estabelecido nos povos semitas e em vez de modificar este conceito de propriedade, o Corão especifica alguns termos para seu gozo saudável, justo e para seu emprego, seguindo assim a visão de Deus. A propriedade não pode ser desperdiçada ou privar outros do seu uso desta. ${ }^{447}$ O Profeta enfatizou a importância do direito de propriedade ${ }^{448}$.

O Islã também rejeita o asceticismo monástico que glorifica a pobreza e o sofrimento e o calvinismo discutido por Max Weber, que considera a acumulação de riqueza para sua satisfação. Nem a pobreza nem a riqueza são provas de virtude, mas para o Islã, ambos são para o julgamento do compromisso destes com Deus. A visão islâmica da riqueza material do mundo é neutra, no sentido de que esta riqueza servirá para demonstrar a submissão deste ser humano a Deus, por sua própria escolha. ${ }^{449}$

A rejeição do asceticismo não é um convite ao consumo. O Islã incentiva a moderação em todos os lados da vida, e enfatiza a importância do comércio e a produtividade. ${ }^{450}$ Apesar das divisões sectárias e religiosas, dentre outras, a ideia de desenvolvimento e cooperação é parte da agenda muçulmana de muitos países. Porém,

446 "Tudo pertence a Deus, mas o homem na terra atua como seu agente." (Corão 2:30)

447 "Eis o livro que é indubitavelmente a orientação dos temente a Deus " (Corão 2:2); "Porque aqueles que malversarem o patrimônio dos órfãos, introduzirão fogo em suas entranhas e entrarão no Tártaro."(Corão 4:10) "Estes possuem a orientação do seu Senhor e estes serão os bemaventurados. Quanto aos incrédulos, tento se lhes dá que os admoestes ou não os admoestes; não crerão." (Corão 2:5-6)

448 "Entre os adeptos do Livro há alguns a quem podes confiar um quintal de ouro, que te devolverão intacto; também há os que, se lhes confiares um só dinar, não te restituirão, a menos que a isso os obrigues. Isto, porque dizem: Nada devemos aos iletrados. E forjam mentiras acerca de Deus, conscientemente." (Corão 3:75)

449 "Porém, uma vez observada a oração, dispersai-vos pela terra e procurai as graças de Deus, e mencionai muito Deus, para que prospereis. " (Corão 62:10)

450 "Ó fiéis, não consumais reciprocamente os vossos bens, por vaidades, realizai comércio de mútuo consentimento e não cometais suicídio, porque Deus é Misericordioso para convosco." (Corão 4:29) 
sob a construção desta lei econômica internacional, os países islâmicos não apresentam o desenvolvimento desejado.

Sob a realidade da economia internacional, a lei econômica islâmica, seus conceitos e prática de desenvolvimento precisam ser renovados, rejuvenescidos e atualizados. Isso de fato é um desafio porque os estados islâmicos devem acomodar suas relações com outras nações, de forma pacífica, buscando uma coexistência. No entanto, a lei islâmica procura sempre se adaptar e sua própria evolução, se a analisarmos, veremos que os estudiosos têm buscado isso constantemente.

A tendência de desenvolvimento corrente exorta que os atores internacionais tomem uma abordagem compreensiva e holística para combater a visão segmentada, excessivamente estreita. No Islã o desenvolvimento lida com ambos os pontos, as questões materiais e as questões espirituais, já que em sua visão ambos se sobrepõem e interlaçam de várias maneiras. De fato, discussões de temas base são centrais para o desenvolvimento: a justiça social, pobreza, guerra e mesmo o significado de progresso são temas muito discutidos no Islã.

O Islã tem abordado os porquês e o como sobre a pobreza, miséria e estrato social. As instituições islâmicas têm um papel importante auxiliando os que possuem necessidades de várias formas, trabalhando para superar a pobreza. As leis contra a riba, a obrigatoriedade do zakat e a caridade têm sua origem no princípio da justiça social, fazendo com que sejam mais bem distribuídos os recursos.

As revoluções do princípio deste século, a revolução islâmica e mesmo a própria primavera árabe demonstram que a religião permanece sendo uma poderosa força em influenciar o desenvolvimento na sociedade mundial. Com firmeza e flexibilidade, a lei islâmica tem buscado sobreviver às forças politicas do colonialismo e influências culturais e mesmo do materialismo. Os ensinamentos islâmicos têm sido preservados e continuam guiando os muçulmanos. Seus princípios básicos são protegidos pelo tradicionalismo inerente do sistema. Os líderes religiosos buscam a todo custo o caráter original da estrutura da sociedade da época do Profeta.

Reconhecemos que através da passagem do tempo e das interações com outros povos, a prática do islamismo tem adquirido várias faces. Podemos citar os ortodoxos, modernistas, fundamentalistas e mesmo um Islã radical e militante e cada um destes terá sua própria visão do desenvolvimento internacional. Nesta pesquisa nos concentramos em Assadr e sua visão da economia islâmica, como um dos principais pensadores da 
contemporaneidade, debatendo sua visão com outros autores. $\mathrm{O}$ futuro desenvolvimento dos estados islâmicos depende de sua capacidade de adaptação da lei islâmica nas relações econômicas internacionais, sem deixar de ser coerentes com seus princípios.

O mundo islâmico, ${ }^{451}$ como um grupo possui todas as possibilidades para desenvolvimento, crescimento e avanço. Os países-membros da Organização de Cooperação Islâmica ${ }^{452}$ são dotados de vastos recursos econômicos como energia, capital, recursos humanos, agricultura e terras aráveis dentro de uma área estratégica. Estes ainda possuem quase $70 \%$ de reservas de petróleo e $50 \%$ das reservas de gás natural. Como um todo, os grupos de países também possuem boa quantidade de capital que poderia formar uma estrutura para desenvolvimento, promoção da cultura islâmica, conhecimento e uma reforma da sociedade.

Como outras grandes civilizações, a islâmica sofreu um período de decadência, levando a um declínio e estagnação. Uma causa direta do desenvolvimento do moderno mundo islâmico está ligada à fraqueza do Império Otomano, quando este saia de sua fase mais islâmica e caminhava para o modelo feudalista. A política do estado estava alinhada para atender à demanda do ocidente industrializado, negligenciando a industrialização local. Com isso, o progresso no mundo islâmico se tornou difícil, fazendo com ele que perdesse espaço. Com as intervenções do Ocidente, principalmente nas províncias periféricas, o Império Otomano começou a desintegrar, pois estavam sujeitas ao controle politico e incapazes de decidir seus ideais políticos, econômicos e sociais.

O século XVI marcou a ascensão do Ocidente quando a ciência e a tecnologia inspiraram o desenvolvimento de todos os aspectos da vida econômica, política e social.

\footnotetext{
${ }^{451}$ Mundo islâmico aqui falamos sobre os países que fazer parte da Organização dos Países Islâmicos.

${ }^{452}$ República do Azerbaidjão, Reino Hashemita da Jordânia, República Islâmica do Afeganistão, República da Albânia, Estados Unidos dos Emirados dos Árabes, República da Indonésia, República do Uzbequistão, República da Uganda, República Islâmica do Irã, República Islâmica do Paquistão, Reino do Barein, Brunei-Darussalam, República de Bangladesh, República do Benin, Burquina Faso, República do Tadjiquistão, República da Turquia, Turcomenistão, República do Chade, República do Togo, República da Tunísia, República Democrática da Argélia, República do Djibuti, Reino da Arábia Saudita, República do Senegal, República do Sudão, República Árabe da Síria, República do Suriname, República da Serra Leoa, República da Somália, República do Iraque, Sultanato de Omã, República do Gabão, República da Gâmbia, República da Guiana, República do Guiné, República da Guiné-Bissau, Estado a Palestina, União do Comoros, República do Quirguistão, Estado do Catar, República do Cazaquistão, República dos Camarões, República da Costa do Marfim, Estado do Kuwait, República do Líbano, Líbia, República das Maldivas, República do Mali, Malásia, República Árabe do Egito, Reino do Marrocos, República Islâmica da Mauritânia, República do Moçambique, República do Niger, República Federal da Nigéria, República do Iêmen.
} 
O mundo muçulmano enfrentava naquele período fraquezas internas, as quais os levaram à queda e sucumbiram assim à estagnação. A existência de instituições interconectadas, valores e motivações que promoviam o livre comércio dentro de um espaço moldado por politicas democráticas foi a causa do sucesso da ciência e do progresso econômico para o Ocidente.

Para os muçulmanos, o colonialismo resultou no declínio da devoção religiosa e o mesmo foi estimulado pela aplicação da lei islâmica através do mundo muçulmano no último século, ou seja, na tentativa de retomada de sua base religiosa, o poder dos colonialistas vem se enfraquecendo. Os esforços para o desenvolvimento do mundo islâmico pós-colonialismo têm induzido o mundo a adotar novas formas de organizar sua vida, trazendo assim uma mistura dos ensinos e a prática da lei islâmica.

Para Assadr, os novos símbolos e a cultural ocidental somente haviam prejudicado o desenvolvimento do mundo muçulmano, sendo que aquela cultura introduziu valores morais prejudiciais, confusão e dilemas irreconciliáveis na mente dos muçulmanos, já que seus valores sociais, culturais e herança religiosa são incompatíveis com o modo de vida islâmico.

Sendo fragmentado o mundo muçulmano, os países se dividiram em ditaduras politicas, monarquias absolutas, entre outros modelos que trouxeram também a corrupção e o subdesenvolvimento. Estes modelos políticos construídos com uma base ocidental, baseada nas ideias nacionalistas, acabaram terminando em estados fracassados. ${ }^{453}$ Devido à estratégia e outras razões políticas, muitos ainda sofrem com interferências diretas e indiretas de países do Ocidente.

Não é surpreendente quando ouvimos que o mundo muçulmano tem contribuído pouco para a ciência nos últimos séculos. Porém, estes viveram por um longo período de dilemas em se adaptar a uma nova cultura ou permanecerem fiéis às tradições e ainda hoje há um debate do quanto poderia contribuir positivamente para o mundo islâmico a utilização da lei islâmica como sua base para a economia, o legislativo e a política.

Os movimentos de reformas, como ocorreu no Irã, procuram tornar o "sistema realmente islâmico" 454 , lançando fora toda a impureza, contaminação e acréscimo do sistema capitalista ou mesmo das crenças locais, o sufismo e outras religiões.

\footnotetext{
${ }^{453}$ Após a queda do Império Otomano e as divisões do Oriente Médio, foi feita uma divisão dos países sem considerar base religiosa, cultura e grupos étnicos.

${ }^{454}$ Essa frase foi colocada pelos entrevistados no Irã.
} 


\subsubsection{A Lei Islâmica e as Preocupações com o Desenvolvimento e Cooperação}

Para os muçulmanos, a questão que surge é: a demanda por desenvolvimento e progresso virá pela imitação dos países industrializados do ocidente, procurando atingir o crescimento econômico e o modelo democrático de governo, ou deve-se ir em uma direção específica, buscando aplicar a lei islâmica na sociedade? A visão padrão é de que os estados devem seguir o modelo geral, e poderia ser extremamente surpreendente se algum país pudesse ser progressista e moderno, sem adotar o modelo ocidental. ${ }^{455}$

Para os muçulmanos - também para Assadr - a chave para o desenvolvimento são as fontes da lei islâmica, alguns aspectos bem descritos pelo Corão e outros conceitos que devem ser trabalhado pelos juristas. Na visão de Assadr, por estudar o sistema ideológico, legislativo e a construção do sistema islâmico, fica claro que a mensagem islâmica visualiza o homem e suas atividades como algo objetivo, para se mostrar sua servidão ao Criador. A condição mental islâmica e sua forma de pensar a relação com a ideologia, a adoração e o progresso material devem estar alinhadas ao Corão, ou seja, sua vida presente focada a sua devoção e sua vida pós-morte.

De acordo com o Islã, foi dado ao homem a responsabilidade do desenvolvimento e progresso, sendo que é qualificado para viver na terra e com isso é responsável pelo balanceamento das relações entre os seres humanos no atendimento de suas necessidades, o relacionamento com o universo e seu criador.

Para a fundação da ummah é o indivíduo e o desenvolvimento dos indivíduos em atingir a excelência de seu potencial que promoverá o desenvolvimento da Ummah. O ensinamento islâmico, por um lado, é de que a responsabilidade do individuo ${ }^{456}$ no atender a si mesmo e por outro lado, cuidar do ambiente dando a devida atenção aos efeitos de seus atos na formação de ideias, intenções e ações de cada um que há extensão no destino da própria pessoa e da sociedade.

Para tentar explicar o conceito e amplitude da ideia da comunidade (ummah) AlMerad (2001, p.34) declara seguinte:

\footnotetext{
${ }^{455}$ Depois da queda do Muro de Berlim, parece "natural" ser liberal, ou seja, realmente teríamos naquele momento o "fim da história", mas de fato essa mentalidade não parece difundida da mesma forma no Irã, dentro do circulo da Universidade de Qom que foi visitada. Há um questionamento e uma visão de falência do Estado Moderno e do modelo capitalista.

456 "Ó fiéis, precavei-vos, juntamente com as vossas famílias, do fogo, cujo alimento serão os homens e as pedras, o qual é guardado por anjos inflexíveis e severos, que jamais desobedecem às ordens que recebem de Deus, mas executam tudo quanto lhes é imposto.” (Corão 66:6)
} 


\begin{abstract}
"O significado de comunidade como definido por cientistas políticos e sociais extende de um grupo de "pequena localidade" dentro de uma sociedade para "qualquer área de vida comum, vila ou cidade ou distrito ou país ou mesmo grandes áreas". O denominador líder do conceito no ocidente de uma comunidade a localidade geográfica a territorialidade física: o termo islâmico para comunidade é Ummah, derivado diretamente de 'umm' que significa mãe. Ummah no Islã de acordo com Abdo Elkoly significa mais que uma terra mãe em seu sua limitação geografia territorial. Significa fé e crença. Ummat al-Islã englobava toda a coletividade da comunidade muçulmana independente de onde ele residisse."
\end{abstract}

A palavra ummah é mencionada sessenta e quatro vezes no Corão, ou seja, a questão da comunidade foi uma importante questão abordada pelo Profeta. Outro ponto a que o Corão dá ênfase é que a criação do homem é somente por Deus, ibadah, que não significa somente adoração, mas também trabalho, ou serviço. O homem deve então não somente adorar, porque sua vida está atrelada a Deus em todos os aspectos, mas aqui neste aspecto trata-se também da questão da prática da justiça do trabalho humanitário na cooperação dentro da ummah e fora.

O Islã utiliza duas fontes que podem ter um papel de nutrir e corromper o desenvolvimento individual humano. O Corão como forma de nutrir seria a fonte do desenvolvimento humano ${ }^{457}$ e não prestar a devida atenção à orientação divina e sucumbir as tentações do mal, decorrente de dentro ou elementos externos, corrompe o desenvolvimento humano. ${ }^{458}$ A economia islâmica, no âmbito doméstico e nas relações internacionais foca esse desenvolvimento da alma humana e sua capacidade para o desenvolvimento material, pois sua base é a fé, conhecimento que resulta em uma obediência humana que estimula no homem um sentimento que afetará suas atividades diárias, em relação ao mundo ao seu redor.

Sem a mudança do próprio homem, para o islã, não haverá uma integração e desenvolvimento. Ou seja, a própria pessoa, ou o "eu" se torna o ponto principal para qualquer projeto de desenvolvimento no Islã. Nenhum desenvolvimento material, nem integração serão atingidos sem um trabalho a partir deste ponto. De fato, se atingido algum desenvolvimento material sem a mudança deste próprio homem, o que temos

\footnotetext{
457 "Não criei os gênios e os humanos, senão para Me adorarem. ”(Corão 51:56)

458 "Satanás vos atemoriza com a miséria e vos induz à obscenidade; por outro lado, Deus vos promete a Sua indulgência e a Sua graça, porque é Munificente, Sapientíssimo.”(Corão 2:268)
} 
presenciado no sistema internacional, com a desigualdade econômica dos estados, é a injustiça, dominação, levando à corrupção do sistema e guerras. ${ }^{459}$

Outro ponto que é trazido a discussão é o khilafah ${ }^{460}$. A humanidade é apontada como a executora dos comandos de Deus, sendo que o homem será apenas o gerenciador e não proprietário na terra. Como um beneficiário e não um dono ou controlador, ${ }^{461}$ portanto deve haver uma manutenção com determinados limites garantidos pela lei islâmica. ${ }^{462}$ Em sentido grupal, ou seja, internamente dentro da ummah o sistema é estabelecido pelo apego mútuo dos indivíduos, ${ }^{463}$ sendo que no nível universal, o relacionamento da comunidade humana também deve ser tratado pelas leis corânicas. ${ }^{464}$

Um dos principais objetivos do Islã é o estabelecimento da justiça, segundo sua lei, buscando o desenvolvimento e equilíbrio, através do desenvolvimento completo da comunidade muçulmana em larga escala. O Islã promove e apoia a função do mercado com mecanismos para manter operativas as forças naturais, tratando este sistema das atividades através da lei islâmica. ${ }^{465}$ As operações do sistema de mercado na distribuição das mercadorias ${ }^{466}$ são apoiadas por dois elementos, um sendo o mecanismo formal e regulatório que estabelece instituições ${ }^{467}$ para reforçar e melhorar a lei islâmica,

\footnotetext{
459 "Por outra, os fiéis, que praticam o bem, são as melhores criaturas, " (corão 98:7)

460 "(Recorda-te ó Profeta) de quando teu Senhor disse aos anjos: Vou instituir um legatário na terra! Perguntaram-Lhe: Estabelecerás nela quem ali fará corrupção, derramando sangue, enquanto nós celebramos Teus louvores, glorificando-Te? Disse (o Senhor): Eu sei o que vós ignorais. " (Corão 2:30)

461 "Respondeu-lhe: Considera-te entre os tolerados!" (Corão 7:15)

462 "Isto, porque Deus é Verdadeiro e vivifica os mortos, e porque é Onipotente. ”(Corão 22:6); "Quando os parentes (que não herdeiros diretos), os órfãos e os necessitados estiverem presente, na partilha da herança, concedei-lhes algo dela e tratai-os humanamente, dirigindo-vos a eles com bondade." (Corão 4:8)

463 "Sois a melhor nação que surgiu na humanidade, porque recomendais o bem, proibis o ilícito e credes em Deus. Se os adeptos do Livro cressem, melhor seria para eles. Entre eles há fiéis; porém, a sua maioria é depravada."(Corão 3:110)

464 "No princípio os povos constituíam uma só nação. Então, Deus enviou os profetas como alvissareiros e admoestadores e enviou, por eles, o Livro, com a verdade, para dirimir as divergências a seu respeito, depois de lhes terem chegado as evidências, por egoística contumácia. Porém, Deus, com a Sua graça, orientou os fiéis para a verdade quanto àquilo que é causa das suas divergências; Deus encaminha quem Lhe apraz à senda reta. "(Corão 2:213); "A princípio, os humanos formavam uma só comunidade; então, dividiram-se. Porém, senão tivesse sido por uma palavra proferida por teu Senhor, Ter-se-iam destruído, por causa de suas divergências. " (Corão 10:19)

${ }^{465}$ Através da instituição da hisbah.

${ }^{466}$ Vide as questões abordadas por Assadr na distribuição antes da produção e depois da produção.

${ }^{467}$ Como os bancos e as instituições legais regulatórias governamentais
} 
procurando promover a eficiência do mercado ${ }^{468}$ e o funcionamento completo do governo; ${ }^{469}$ e os mecanismos morais, os quais devem encorajar, e até certo ponto requer a repartição do excesso de ganhos no mercado com outros cidadãos não tão afortunados e que não possuem a mesma habilidade de competir e ganhar o suficiente do sistema de mercado. ${ }^{470}$

A lei islâmica, através da instituição da $h i s b a h,{ }^{471}$ sujeita as atividades de ganho a certas prescrições divinas, que definem o limite do halal e do haram. Estas prescrições têm a intenção de prevenir a opressão e frear a injustiça, ganho imoral e as atividades comerciais prejudiciais ao interesse coletivo da sociedade.

De fato, o governo, através de seus órgãos administrativos, dentro do mecanismo de mercado é responsável por organizar um sistema distributivo formal que complemente o mercado através de mecanismos tais como bait-al-mal, ${ }^{472}$ bens públicos ${ }^{473}$, zakat e caridade, a fundação piedosa do ribat, ${ }^{474}$ madrassahe a fundação do waqf. ${ }^{475}$

Além deste sistema, também foram criadas obrigações sociais através de instituições que procuram promover a justiça social e segurança através de uma rede de setores usando mecanismos tais como infaq sadaqah, qadr, hassan e waqfe, outras opções financeiras que resultem em uma renda halal ou mesmo auxílio para os que não podem conseguir seu ganho justamente. ${ }^{476}$ Através destes dois controles, o sistema procura manter a riqueza em circulação e as chances de concentração são minimizadas.

\footnotetext{
${ }^{468}$ No tempo do Profeta é citada a instituição do Muhtasib, hoje ocorre à promoção de diversas formas citados no primeiro capitulo desta parte da tese.

${ }^{469}$ Aqui deve ser dada atenção à forma com que o Profeta estabelece seu governo

470 "Perguntam-te que parte devem gastar (em caridade). Dize-lhes: Toda a caridade que fizerdes, deve ser para os pais, parentes, órfãos, necessitados e viajantes (desamparados). E sabei que todo o bem que fizerdes, Deus dele tomará consciência." (Corão 2:215)

${ }^{471}$ Palavra em árabe que significa "responsabilidade".

${ }^{472}$ Um conceito de gerenciamento de receitas e despesas originados do tempo do Profeta.

${ }^{473}$ Estes devem ser utilizados em prol da população, os bens públicos serão para administrar e gerar riquezas que estão a serviço da comunidade muçulmana.

${ }^{474}$ Ribat é um esquema organizado pelos muçulmanos para que os indivíduos de me melhor condição de vida ofereçã livre acomodação aos viajantes, aos pobres e indigentes, que prevaleceu no período medieval do Islã.

${ }^{475}$ KURAN, Timur. The Provisiotn of Public Goods under Islamic Law: Origins, Impact and Limitations of Waqf System.IN: Law \& Society Review, Vol 35, 2001, p.842

${ }^{476}$ Assadr menciona essa questão em seu modelo de economia islâmica, quando comparando o sistema com o marxismo. Defende a questão de que nem todos no sistema serão capazes de conseguir um ganho devido a limitações físicas e mentais e o sistema social deve sim cuidar destes.
} 
Para atingir um sistema econômico-social perfeito, o mundo deveria ser organizado como um Estado, ou seja, em um sistema ordenador onde os arranjos sociais, econômicos e políticos nos quais as pessoas vivam e trabalhem estejam sob mesma ordenação. ${ }^{477}$ Essa organização do mundo depende de diversos níveis de arranjos e funções, sendo que a mais importante seria a política, pois é uma parte essencial para a organização da vida humana. Em outras palavras, o Islã encara que para a salvação pessoal é necessário que as instituições estejam de acordo com as regras do Islã, ou seja, o Estado é indispensável como instrumento doutrinal e para se atingir os objetivos religiosos. ${ }^{478}$

Diferente da democracia secular, no Islã esse poder é "emprestado" de Deus ${ }^{479}$, mas o poder não é o desejo das massas, mas sim o poder de garantir que a regra da lei seja cumprida. ${ }^{480} \mathrm{O}$ cumprimento desta lei, ou seja, as sanções servem para garantir o bem e eliminar as injustiças da sociedade. Esta é a obrigação primária e original da lei islâmica. Os limites da interferência são definidos pelas políticas públicas, buscando os propósitos da lei islâmica, o cumprimento das tarefas e responsabilidades do estado.

No Islã, todos os atos são avaliados em termos de suas consequências em bens sociais e benefícios e detrimento social. Os planejadores muçulmanos, os administradores, no cumprimento de suas obrigações, devem sempre buscar cumprir o desejo do bem comum da ummah. Repensando a coexistência internacional, o governo islâmico então lutará pelo bem comum de todos os seres humanos. ${ }^{481}$ Isto significa que eles devem lutar por harmonizar e assim cumprir os interesses de todos. No entanto, sabemos que é impossível satisfazer imediatamente todos estes interesses, por isso restringe-se ao interesse na proteção da religião, vida, propriedade, sabedoria, respeito

477 S.M.HASSANUZ-ZAMAN. Economic Functions of Islamic State- The Early Experience. Leicester, UK: The Islamic Foundation, 1991 p.74. Essa visão é intrínseca da Ummah. Defende a dificuldade de organizar o sistema devido aos interesses dos Estados, trazendo assim a falta de união entre os muçulmanos.

${ }^{478}$ KHADDURI, Majid. Islamic Law of Nations: Shaybani's Siyar, 1966 p.5

479 "Entre os humanos há aqueles que adotam, em vez de Deus, rivais (a Ele) aos quais professam igual amor que a Ele; mas os fiéis só amam fervorosamente a Deus. Ah, se os iníquos pudessem ver (a situação em que estarão) quando virem o castigo (que os espera!), concluirão que o poder pertence a Deus e Ele é Severíssimo no castigo." (Corão 2:165)

${ }^{480}$ Aqui cai a questão do debate de como seria a democracia na lei islâmica, tendo uma pluralidade de desejos que devem estar de acordo com o Corão.

${ }^{481}$ SIDDIQI, M.N. Principles of International Economic Relations in Islam, in: M.A. Mannan, Monzer Kahf e Ausaf Ahmad, International Economic Relations from Islamic Perspectives (Ed.) Jeddah, Saudi Arabia: IRTI, (1992), p.31. 
próprio e honra. ${ }^{482}$ Portanto, vemos que a lei islâmica na área internacional busca atender ao bem-estar de um grande número, já que visualiza todos os seres humanos. A organização da ummah é um desejo que engloba a segurança e direitos individuais de todos.

Após a solidificação da União Europeia, a Organização dos Países Islâmicos compreende o importante impacto sobre outros grupos econômicos regionais, tanto no crescimento econômico quanto no desenvolvimento de seus membros. Do aspecto da prática da lei econômica internacional, mostramos a ativa participação dos estados islâmicos no desenvolvimento regional e internacional. O desenvolvimento cooperativo tem contribuído para o desenvolvimento da situação das pessoas. Para o Islã, a cooperação regional ou universal é algo indispensável para a coexistência.

O crescimento da cooperação econômica islâmica data de 1969 pela Primeira Conferencia em Setembro daquele ano, onde a Organização dos Países Islâmicos organizou atividades para auxiliar a promoção e desenvolvimento para cooperação entre seus membros. Seus membros fazem parte do Banco Islâmico de Desenvolvimento que tem desenvolvido relacionamentos profissionais com outras instituições islâmicas tais como o Centro Islâmico para Desenvolvimento do Comércio, a Câmara Islâmica de Comércio e Indústria, o Comitê para Cooperação Econômica e Comercial e a Conferência Islâmica de Ministros das Relações Exteriores.

Várias conferências e artigos têm sido produzidos identificando as necessidades de desenvolvimento da Ummah. No entanto, o sucesso dos esforços bancários são uma manifestação nas áreas econômicas e na cooperação comercial. Isto inclui assistência a assuntos relacionados a países membros da OMC e estabelecimento da Cooperação Islâmica para Seguro de Investimento e Crédito de Exportação para encorajar o investimento e o comércio entre os estados islâmicos ${ }^{483}$.

No que diz respeito ao programa de assistência destinada a promover o desenvolvimento econômico e o progresso social nas comunidades muçulmanas e nãomuçulmanas pelo mundo, principalmente através da criação de instituições e desenvolvimento em educação, saúde, e outros setores sociais. Providenciar assistência e suporte para países membros e comunidades muçulmanas em casos de desastres naturais

\footnotetext{
${ }^{482}$ A ênfase nestes pontos foram dadas nas entrevistas quando se colocava o interesse de proteção que a lei islâmica busca.

483 Islamic Development Bank, Annual Report 1423.
} 
e fome e alívio para refugiados, um esforço tem sido feito pelos bancos como as principais agências de desenvolvimento da Organização Países Islâmicos.

Os estudiosos têm sugeridos medidas ativas que poderiam ser incitadas dentro da Organização dos Países Islâmicos e do Banco Islâmico de Desenvolvimento para utilizar os fundos baseados em caridade ${ }^{484}$ de forma que estes recursos pudessem ser utilizados pela comunidade islâmica. Há muitos grupos de voluntários em nível nacional ativos neste campo, mas é necessário fazer um esforço conjunto para que se possa ter o desenvolvimento da Organização dos Países Islâmicos, como a Ummah Welfare Trust ${ }^{485}$ e o Mercy Malasia Medical Relief. ${ }^{486}$ Porém, as principais instituições do mundo islâmico ${ }^{487}$ têm falhado em atingir a meta da autossuficiência, mostrando que é necessário a revitalização da secretaria da Organização dos Países Islâmicos.

O grupo de países islâmicos adotaram cada um sua própria forma de capitalismo e modelos de governo, sem pensar nos problemas decorrentes destas adaptações e deixando de lado a questão das bases das instituições que formam a estrutura governamental $^{488}$. Estruturas de comércio, mantendo assim pouca participação no comércio mundial e assim a expansão dos países permaneceram medíocres, ${ }^{489}$ uma fraca coordenação do comércio, fraco desenvolvimento de suas políticas públicas. Outro ponto importante que podemos destacar é a dependência da importação de tecnologia, ou seja, é necessário o desenvolvimento tecnológico e dos recursos humanos para que realmente seja necessário o desenvolvimento dos países.

Para os defensores da economia islâmica, ${ }^{490}$ a coexistência entre os muçulmanos e não-muçulmanos deve se pautar na doutrina do taqarub, ou seja, a busca de uma

\footnotetext{
${ }^{484}$ Zakat, sadaqah e waqf

${ }^{485}$ Sociedade registrada no Reino Unido

${ }^{486}$ É uma organização sem fins lucrativos com foco na prestação de socorro médico, atividades de desenvolvimento e de redução dos riscos relacionados com a saúde sustentável para as comunidades vulneráveis em ambas as situações de crise e de não -crise. Como uma organização sem fins lucrativos, MERCY Malásia se baseia exclusivamente em financiamento e doações de organizações e indivíduos generosos para continuar os seus serviços e prestar assistência humanitária aos beneficiários, tanto na Malásia e no exterior. A organização é uma sociedade registada de acordo com a Lei de Sociedades na Malásia, e a sede encontra-se na capital de Kuala Lumpur.

${ }^{487}$ Organização dos Países Islâmico e o Banco para Desenvolvimento Islâmico

${ }^{488}$ Masudul Alam Choudhury, Islamic Epistemological Question Applied to normative Issue of Trade and Development in Muslim World at $<$ http://islamic-finance.net/

${ }^{489}$ Nesta tese não focamos todas as questão e problemas apresentados pelo mundo islâmico, mas sim focamos a parte comercial.

${ }^{490}$ Refiro-me aqui aos entrevistados na Universidade de Qom.
} 
coexistência pacifica entre os estados islâmicos e os não-islâmicos. Porém, essa coexistência deve ser igualitária para todos os estados, trazendo dignidade, algo não encontrado no sistema econômico internacional.

Outros pontos levantados sobre a contribuição do Islã para o desenvolvimento e para a cooperação internacional são as qualidades próprias da religião que são aplicadas através da lei islâmica ${ }^{491}$ por parte de instituições públicas e do voluntariado que tem sido ignorado e marginalizado no âmbito econômico devido à preocupação dos estudiosos com as proibições da usura dentre outros pontos.

Para facilitar a coexistência entre a ummah e as outras comunidades mundiais é necessário, no entanto, chegar a uma cooperação e criar um pacto de lealdade, para as transações entre as diferentes sociedades, usando o comportamento do Profeta, quando migra para Medina, como forma de criar os princípios para a lei internacional. Mas, é perceptível que dentro do jogo de interesses da sociedade moderna, há grande dificuldade de persuadir os governos a cooperarem.

O desenvolvimento econômico internacional com seus vários tons e focos tem desenvolvido a sociedade e trazido determinado progresso, mas com uma distribuição desigual da riqueza, sem conseguir erradicar a pobreza.

\subsection{A Área de Liberdade para Assadr}

Nosso autor de referência para a análise do relacionamento entre o capitalismo e a economia islâmica, além de seu trabalho no livro Iqtsaduna e sua pesquisa sobre a banca islâmica no Kuait também atuou na área de jurisprudência islâmica, sendo seu trabalho na área ainda mais expressivo.

Assadr acredita que o Islã é um tipo de religião que cobre todos os aspectos da vida e precisa então achar uma forma de ser praticada, isso obviamente através da lei. De fato, a teoria "logica vacum" foi extremamente importante para o desenvolvimento da jurisprudência econômica e política.

Como mencionamos nos capítulos anteriores, para Assadr as relações sociais são originadas das necessidades humanas que são divididas em fixas e variáveis. Essas

\footnotetext{
${ }^{491}$ Virtudes como adl, zakat and sadaqah ( justiça distributiva), israf (proibição da extravagância), falah (prosperidade).
} 
necessidades variáveis crescem gradualmente na vida, quanto mais experiência e conhecimento, mais essas necessidades se estendem.

Para Assadr, o Islã divide suas regras entre princípios fixos e variáveis. As regras fixas no Islã são as respostas para as necessidades humanas, como as regras criminais, as regras de como ganhar a via, dentre outras. As regras variáveis são as que precisam de constante ajuste. Nesta discussão de regras variáveis o autor posiciona o líder supremo, que deve agir dentro das regras variáveis em benefício da sociedade islâmica.

Como mencionado nos primeiros capítulos, o autor particularmente acredita em um governo islâmico. As regras de governança são variáveis, partindo do líder supremo, para ganho de justiça e com benefício.

Há um critério para as regras de governança, as necessidades básicas podem ser satisfeitas por regras fixas e aqui é onde o governo tem um papel de maior determinação das regras e o líder supremo deve legislar dando a devida atenção aos objetivos religiosos como a justiça.

Em seus livros, o autor dá ênfase ao fato de que o governo escolhido pela sociedade islâmica deve sempre considerar os benefícios para a população no gerenciamento desta sociedade. Obviamente, este governo deve trabalhar em uma estrutura islâmica, o que auxilia na tomada de decisões.

Muitas vezes, o que ocorre é que os juristas possuem diferentes opiniões em seus julgamentos. Assim, o líder ou o parlamento deve analisar o que é melhor para a sociedade islâmica, mesmo que isso vá contra a opinião de juristas especialistas no tema. $\mathrm{Na}$ falta do Imã, os juristas deveriam tomar para si as questões do parlamento, mas isso na falta do Imã, caso contrário, é dada ênfase à obediência ao líder.

Os representantes de Deus possuem uma margem de trabalho na questão da necessidade de ajustar as regras do país, dentro da estrutura islâmica. Nosso autor de fato insere a economia e as finanças em seus livros sempre dentro de um quadro islâmico, não seria possível uma economia islâmica, puramente islâmica, dentro de uma estrutura que não seja permeada pelo Islã.

A área de liberdade de atuação não é de fato uma permissibilidade para Assadr, mas um símbolo de uma forma dinâmica do pensamento islâmico, as gerações enfrentam problemas continuamente com as mudanças dinâmicas e o Islã precisa assim atender essas necessidades variáveis apresentadas. A questão da proteção da moralidade pública para o autor se resolve através de uma liderança islâmica. 


\subsection{A Política Externa Islâmica}

No estudo do pensamento islâmico na área econômica, podemos identificar os valores básicos, a experiência e história que dão cor às atitudes e influenciam a consciência e estratégia dos estados islâmicos. Podemos perceber que há um ar de amizade, cooperação e conflito. ${ }^{492}$ A história das relações internacionais dos países islâmicos mostra a influência dos valores do Profeta em resposta às pressões internas e externas.

De fato, o objetivo máximo da política externa islâmica deve ser servir ao povo muçulmano e a sua causa sob quaisquer circunstâncias, porém os muçulmanos na atualidade se veem obrigados a se adaptar às mudanças e inovações na área política. ${ }^{493} \mathrm{~A}$ atitude de neutralidade na realidade entre as nações islâmicas nunca foi significante, mas foi importante no sistema europeu no século XIX, porém com as mudanças nas comunicações e na guerra tecnológica desde a Segunda Guerra Mundial, e o novo alinhamento político mostra que a neutralidade se torna mais difícil de ser praticada.

Para AbuSulayman (1993, p.147) são cinco fatores que dão luz ao sistema islâmico. O primeiro é que devem se levar em conta os princípios básicos do Islã, sendo assim o Corão e a história do Islã deverá fornecer a base e princípios para as ações. Segundo, devem ser levadas em conta as ameaças e oportunidades para se atingir os objetivos do Islã. Terceiro, há limitações e forças na sociedade islâmica que devem ser analisadas, na busca de seus objetivos, devem se levar em conta os países islâmicos frente ao sistema internacional. Quarto, o autor cita os recursos dos aliados e adversários, que possam também servir aos objetivos do Islã. Quinto, deve-se ter em mente as limitações do ambiente que limitam como o país irá atuar.

As políticas externas dos países islâmicos devem ser orientadas no sentido de abandonar a guerra com os países não muçulmanos, e na adoção de uma diplomacia de reciprocidade e alianças, levando à frente um princípio de neutralidade, já que estes não se encontram hoje em posição confortável dentro do sistema internacional. Levando ém

\footnotetext{
${ }^{492}$ ABUSLAYMAN, AbdulHamid, Towards an Islamic Theory of International Relations, 1993 p.141.

${ }^{493}$ Podemos aqui citar o caso da ação nuclear no Irã. Nas entrevistas isso é colocado como uma forma de expansão do poder na região e como forma de ganhar armas no jogo político internacional. A intenção parece ser apenas de angariar poder político como potência na região. Como argumentamos a questão do estado falar de igual com outros Estados, e não com inferioridade.
} 
conta a própria história do Império Otomano, eram envidas missões diplomáticas à Europa, no sentido de criar alianças, fazendo assim trocas tecnológicas e trazendo crescimento de poder a ambos os lados. ${ }^{494}$

Como mencionamos acima, o Islã não aceita o conceito de dualidade, ou seja, um sistema secular e um sistema religioso, as diferenças de opinião entre a autoridade politica e a jurídica não necessariamente significam que somente os juristas agem de acordo com o Islã, as autoridades polticas precisam considerar diversos fatores, elementos dentro de seu sistema.

AbuSulayman (1993, p.142) procura criar esquemas para que possamos compreender como ocorren as decisões na área de relações internacionais. O pensamento contemporâneo apresenta a intenção de se integrar a ideologia ao ambiente e assim adquirir poder dentro do sistema internacional.

${ }^{494}$ Nos capítulos II e III, o autor AbuSulayman abordará a história das relações internacionais no Islã, procurando mostrar através da história o modelo a ser seguido. 
Figura 5: Sistema Moderno de Relacionamento Islâmico

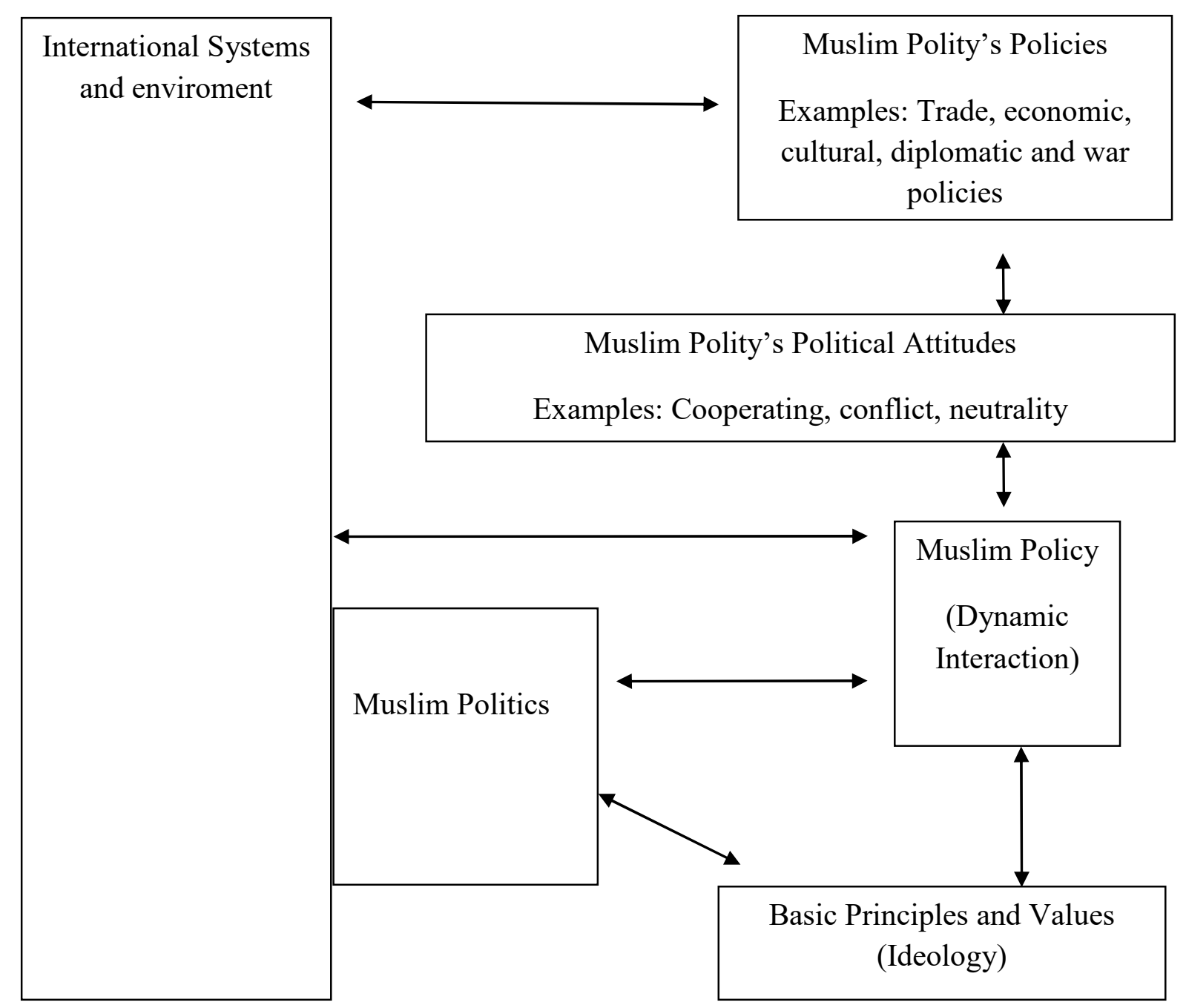

Fonte: Abusulayman, A. Towards a Islamic Theory of International Relation, 1993, p.146.

O processo de islamização das políticas dentro das ações tem o intuito de formatar o sistema atual de acordo com as políticas utilizadas pelo Profeta. Portanto, a ideia da Ummah será sempre persistente, mas os entrevistados reconheciam que há grandes dificuldades de uma colaboração. 


\section{CONCLUSÕES}

Estudar a história econômica do século XX é fazer uma pesquisa do processo de globalização do capitalismo, já que esta narrativa de expansão oferece ótimas explicações às ações políticas, às guerras e à instabilidade encontrada no sistema internacional. Mas podemos ousar aqui dizer que nos livros falta um grande episódio, a parte que cabe explicar como o capitalismo se adapta e adentra os países islâmicos.

Nossa proposta era analisar a questão do relacionamento entre o capitalismo e a economia islâmica, usando Muhammad Baqir Assadr como referência, sendo que em seu principal trabalho o autor tece críticas duras tanto ao capitalismo, ao socialismo e comunismo.

Tendo em vista essas críticas, levantamos a questão da possibilidade de relacionamento entre a economia islâmica e o capitalismo, já que seria possível debater o relacionamento com o modelo comunista e socialista, tendo em vista que os estados que se declaram como tais permaneceram e permanecem fechados em suas economias.

Para apontar nossas conclusões e descrevermos da melhor forma possível as possibilidades de relacionamento entre os modelos, procuramos elaborar três capítulos, descritivos, mostrando as ideias de Baqir Assadr, seu discurso crítico e os pressupostos islâmicos para lidar com o mercado internacional.

Com base nesta construção, primeiramente constatamos que a economia islâmica é estudada apenas em sentido doméstico, ou seja, tem-se pensando em seu desenvolvimento sem considerar as relações com outros modelos, portanto, esta tese se apresentou como um desafio gigantesco a princípio, trabalhar com um autor desconhecido como Assadr e ainda extremamente desconhecido do campo de pesquisa da economia, nos levou a uma busca árdua por informações.

Nesse cenário extremamente conturbado da economia internacional, o surgimento de um modelo islâmico traz ainda maior preocupação, já que o Islã rejeita a agressiva força da globalização econômica e cultural e procura adentrar ao sistema econômico internacional de forma integrativa, mantendo suas características religiosas e singularidades de sua cultura, ou seja, aceita e adapta aquilo que não é contrário às normas islâmicas.

É importante ressaltar que, nas entrevistas realizadas no Irã, foi possível perceber certo padrão nas respostas e um posicionamento positivo por parte dos estudiosos, no 
quesito de desenvolver um bom relacionamento com o mercado capitalista, desde que fossem respeitadas sua forma de governo e crenças.

A briga parece ser com a agressiva ideologia neoliberal e com a forma arrogante do imperialismo, tentando impor suas formas de governo, cultura e base de consumo. $\mathrm{O}$ Islã em si não se apresenta como um modelo fechado, isso é perceptível pela própria história.

Nesse sentido, no processo histórico da globalização do capitalismo, ao que parece, temos mais um episódio da globalização, a do chamado "mercado islâmico", que foi assumindo diversas características do modelo de economia de mercado, mas impõe as crenças islâmicas na gestão do estado, criando um "estado de bem-estar social islâmico".

A lei islâmica não apresenta uma proposta ao fechamento do mercado e também não temos indícios entre os especialistas entrevistados em Qom de que os pensadores islâmicos algum dia possam se direcionar a isso. De fato, o que é feito em realidade é uma adaptação aos produtos para tornar "islâmicas as operações", mas como eles mesmos argumentam, são mudanças "softs na estrutura das operações", de forma que não haja empecilhos para o funcionamento do sistema.

O comércio para o Islã é o "contato com o mundo" que de fato possibilita também a expansão da religião, mas reconhecem que também precisam de mais tempo para construir um modelo preparado para o sistema internacional, que se apresenta como um caos na visão islâmica. Sendo a questão da justiça o principal ponto, e também o respeito as questões religiosos, organizações como a OMC não fornecem uma base viável para que os países islâmicos possam atuar no mercado internacional.

Porém, a lei islâmica aplicada no âmbito internacional ainda está em desenvolvimento, e devemos lembrar aqui que a tendência é sempre ao protecionismo, já que cabe ao mercado a manutenção da vida dos muçulmanos. A abertura de mercado será seletiva e não há intenções de participar de grupos multilaterais de negociação, já que este sistema internacional é visualizado como extremamente injusto.

O que foi pautado por todos os entrevistados é que a proteção do mais fraco sempre deverá estar à frente do sistema, pois é um pilar do islamismo e o consumo deve ser contido, moderado e um bloqueio do modelo capitalista deve ser mantido. Aliás, a intervenção é algo fundamental para o Islã, trazendo em sua visão benefícios para a sociedade. 
A visão islâmica deste mercado capitalista internacional ainda é tão crítica e drástica quanto de Assadr, já que nos discursos de hoje esta extrema racionalização da exploração do mercado ainda é considerada cruel. O importante na base da ideia da economia no Islã é o atendimento das necessidades da população e não a máxima do lucro.

O modelo econômico islâmico deseja achar uma forma com que os muçulmanos possam se manter fiéis à religião, abraçar o capitalismo da mesma forma que o cristianismo o faz e que permite uma vida com espaço a fidelidade a Deus. Como o capitalismo se mostra adaptável, percebemos aqui uma soma, que talvez tenha ocorrido de forma sutil, mas uma adaptação que e a criação de um mercado islâmico.

Esse processo de islamização e adaptação, obviamente traz infelicidade a grupos mais fundamentalistas, porém, a direção do estado, com a intenção de trazer o bem estar, procura assim manter as relações e moldar o capitalismo, mas não o cortando de fato, procura neste sistema uma forma, de distribuir a riqueza e desenvolver o bem estar da população.

Nesse sentido, este trabalho compartilha a perspectiva de que um estado islâmico é protecionista dentro dos interesses islâmicos, mas não se fecha assim como nos modelos socialistas instalados em alguns países, nem busca uma planificação da produção. Sua busca pelo estado de bem-estar social será através de um estado forte.

E, mais do que simplesmente propor um novo modelo, o Islã consegue, no que tange à flexibilidade do discurso praticado e à flexibilidade das leis, criar um estado que atende aos desejos dos revolucionários em certa medida e abre a possibilidade de relacionamento com outros modelos e ideologias econômicas, e o que propõe o governo islâmico é balizar todos os aspectos da vida.

Os líderes deverão, ideologicamente, prestar atenção e procurar atender a grande massa da população na sociedade, portanto, ideologicamente se assemelhará ao socialismo, mas repensando em termos de estrutura do sistema econômico, o modelo islâmico apresenta a questão da economia de mercado e defende a propriedade privada como uma forma legitima.

A ideia de um bloco islâmico é considerada pelos estudiosos, mas tem se mostrado impossível na prática, pois não parece haver um hegemon que possa auxiliar na construção de um modelo mais forte e um bloco forte economicamente que poderia impor 
as regras necessárias para maior espaço e poder nas negociações econômicas internacionais.

Para os defensores da economia islâmica, o mercado fechado não é algo necessariamente ruim, pois uma nação pode adquirir força e se concentrar em sua população se tem seu mercado fechado.

Com o intuito de manter a pureza, poderemos perceber talvez momentos de fechamento do mercado, caso não seja respeitado o modelo islâmico, já que os líderes religiosos sempre irão procurar preservar a autonomia religiosa e cultural.

O preço da globalização é considerado muito caro e a desordem mundial que trouxe é vista como um "belzebu" econômico de opressão dos povos. Indo mais além, esses resquícios de capitalismo têm mudado a natureza do Islã e vemos ali uma objetificação. Os valores dos bancos que se apresentam como "islâmicos" não são considerados puros, já que sua base é a máxima lucratividade e não o auxilio da população.

O governo islâmico impõe o fator moral, que pode criar diversas restrições ao relacionamento e também atua como um interventor na economia, algo não bem visto pelos países de ordem liberal. O sistema financeiro, com base e foco em questões sociais também recebe críticas na atualidade, como responsável pelo atraso no Oriente Médio.

O modelo islâmico se apresenta como um processo, no sentido que ainda não é puramente islâmico, já que é necessária toda a islamização de uma sociedade para que assim seja criada uma estrutura na qual possa se apresentar uma economia sem os resquícios de outros modelos econômicos ou mesmo outras doutrinas econômicas.

Assadr critica essa posição, mas também reconhece que para competir com os bancos tradicionais, a banca islâmica teria que se adaptar, mas essa adaptação é vista de forma crítica por muitos estudiosos de visão conservadora.

De fato, parece que a força do comércio consegue aos poucos minar o fundamentalismo, ou seja, o fetichismo da mercadoria, o poder do desejo, o consumo parece combinar com a essência humana e assim a classe média se rende, oferecendo cada vez mais espaço ao espírito do capitalismo. 


\section{BIBLIOGRAFIA}

AHMAD, Khurshid. Studies in Islamic Economics.UK: The Islamic Foundation, 1980. AHMED, Habib (ed.). Theoretical Foundations of Islamic Economics. Saudi Arabia: The Islamic Development Bank, 2002.

AKHAVI, Shahrough. Contending Discourses in Shi'i Law on the Doctrine of Wilayat al-Faqih. IN: Iranian Studies. Vol.29 No 3/4 pp. 229-268.

AL-FAWZAAN, Sheik Saalih bin F. The Forbidden Business Transactions in Islaam. USA: Book Publishing, 2003.

AL-MUSAUI, Sayyed Hashem. O sistema social no Islã. São Paulo: Centro Islâmico no Brasil, 2006.

AL-MUZAFFAR, Ayyatullah Sheikh Mohammad Redha. As Crenças Islâmicas de Acordo com a Escola Xiita Imamiyah Ithna Ashariyah. São Paulo: Centro Islâmico no Brasil, 2009.

ALMOHARBY, Darwish. The current world business meltdown: Islamic religion as a regulator. Humanomics. Vol.27. $\mathrm{N}^{\mathrm{o}} 2$ 2, 2011. pp. 97-108.

ANGEL, N. Regina. Preliminaries and Transitory Measures Toward a Complete Stabilization of the US Dollar, IN: International Journal of Social Economics, Vol.24 1999.

ARMSTRONG, Karen. O Islã. Rio de Janeiro: Objetiva, 2001.

ASSADR, Muhammad Baqir. Iqtisaduna: Our Economics. Iran: World Organization for Islamic Services, 1994.

.Falsafatuna: Our Philosophy.Qum: Ansariyan, 2010.

. Estudos Islâmicos sobre Al-Wilayah e Al-Mahdi. São Paulo:

Centro Islâmico no Brasil, 2006.

. A Escola Islâmica. São Paulo: Centro Islâmico no Brasil, 2010.

AL-TABATABAÍ, Allamah Ayyatullah Al-Odhmah Assayed Mohammad Hussein, $O$ Xiismo no Islam. São Paulo: Centro Islâmico no Brasil, 2008.

AN-NABHANI, Taqiuddin. The Economic System in Islam. Fourth Edition, London: AlKhalifah Publications, 1997.

ASSMANN, H. HINKELAMMERT, Franz. A Idolatria do Mercado: Ensaio sobre a Economia e Teologia. São Paulo: Vozes, 1989. 
AYUB, Muhammad. Understanding Islamic Finance. British: John Wiley \& Sons, Ltd., 2007.

AZIZ, T.M. The Role of Muhammad Baqir al-Sadr in Shii Political Activism in Iraq 1958 to 1980. IN: International Journal of Middle East Studies. Vol.25, Nº 2 (May, 1993), pp.207-222.

BALlAnTyne, William M. STOVALL, Howard. Arab Commercial Law: Principles and Perspectives. USA: American Bar Association, 2002.

BARBER, Benjamin. Jihad vs McWorld. New York: Ballantine Books, 1996.

BATUTU, Hanna. Iraq's Underground Shi'i Movements. IN: MERIP Reports, N 102 , Islam and Politics (Jan., 1982), pp. 3-9.

BAZ, Shaykh Abdul 'Aziz Ibn Abdullah Ibn. Warning Against Riba (Usury) Transactions. Madinah Publishers and Distributors. Disponível em: http://d1.islamhouse.com/data/en/ih_books/single/en_Warning_Against_Riba_Transacti ons.pdf. Acesso em: 07 de Setembro de 2013.

BEEKUN, Rafik Issa. Islamic Business Ethics. VA: International Islamic Thought, November 01, 1996.

BENGIO, Ofra. Shi'is and Politics in Ba'thi Iraq. IN: Middle Eastern Studies, Vol. 21, N. ${ }^{\circ} 1$ (Jan. 1985), pp.1-14.

CHAPRA, Mohammad Umar. What Is Islamic Economics? Kingdom of Saudi Arabia: Islamic Development Bank, 2001.

and KHAN, Tariqullah. Regulation and Supervision of Islamic

Banks. Saudi Arabia: Jeddah, 2000.

and AHMED, Habib. Corporate Governance in Islamic

Financial Institutions. Saudi Arabi: Islamic Development Bank, 2002.

CHOUDHURY, Masudul Alam. Islamic Epistemological Question Applied to normative Issue of Trade and Development in Muslim World. IN: Islamic Economics, Vol. 22 No. 2, pp: 83-89 (2009 A.D./1430 A.H.)

CARVALHO, G. Introdução as finanças internacionais. São Paulo: Pearson, 2007.

COGGIOLA, O. A Revolução Iraniana. São Paulo: Editorai UNESP, 2008.

COLE, Juan. Shi'i Clerics in Iraq and Iran, 1722-1780: The Akhbari -Usuli Conflict Reconsidered. IN: Iranian Studies, Vol. 18, No. 1 (Winter, 1985), pp. 3-34.

COOK, Michael. Commanding Right and Forbidding Wrong in Islamic Thought. Cambridge university Press, 2000. 
EL-ASHKER, Ahmed. WILSON, Rodney. Islamic Economics: A Short History. Boston: Brill, 2006.

EL SAGRADO ALCORÃO, Tradução de Al-Cur'anu-1-karim, Centro Islamico de Venezuela Valencia

FARAH. Paulo Daniel. O Islã e suas fontes. IN: História Viva- Grandes Religiões 4 Islamismo, 2009. pp. 8-13

FARES, Mohamad Ahmad Abou. Islamismo, Mandamentos e Fundamentos. Curitiba: Embaixada da Arabia Saudita, Sem data. , Introdução ao Sagrado Alcorão. Curitiba: Edição do Autor, 1986.

FOSTER, Nicholas H. D. Islamic Perspectives on the Law of Business Organizations I: $\mathrm{Na}$ Overview of the Classical Sharia and a Brief Comparison of the Sharia Regimes with Western-Style Law. IN: European Business Organization Law Review. Vol. 11. Issue 01. March 2010. Pp. 3-34

FOSTER, Nicholas H. D. Islamic Perspectives on the Law of Business Organizations II: The Sharia and Western-style Business Organizations. IN: European Business Organization Law Review. Vol. 11. Issue 02. Junho 2010. pp. 273-307

FRIEDMAN, Milton. Bimetallism Revisited. IN: The Journal of Economic Perspectives Vol. 4, No. 4 (Autumn, 1990), pp. 85-104

GREUNING, Hennie van and IQBAL, Zamir. Risk lanalysis for Islamic Banks. Washington: The World Bank, 2008.

Council of Islamic Ideology, Islamabad Pakistan. Elimination of Riba from the Economy \& Islamic Mode of Financing. Web Edition, 2006.

HAAN, Rodolfo. A economia à luz da Bíblia: reflexões bíblicas sobre dinheiro e propriedade. Aparecida, SP: Editora Santuário, 2012.

HALLAQ, Wael B. The Origins and Evolution of Islamic Law. Cambridge: Cambridge University Press, 2005

- An Introduction to Islamic Law. United States of America: Cambridge University Press, 2009.

HAMIDULLAH, Dr. Mohammad. Introdução ao Islam. São Paulo: Editora Alvorada, 1990.

HAMIDULLAH, Muhammad. Muslim Conduct of State. Lahore, Pakistan: Sh. Muhammad Ashraf. 1953. 
HANNEF, Mohamed Aslan. Contemporary Islamic Economic Thought: A Selected Comparative Analysis. Kuala Lampur: S. Abdul Majeed \& Co., 1995.

HANINI, Zuhra Mohd El. Noções de Direito Islâmico (Shariah). Brasil: Dissertação, 2007.

HASHIM, Muhammad. Islamic Perception of Business Ethics and the Impacto of Secular Thoughts on Islamic Business Ethics. IN: International Journal of Academic Research in Business and Social Sciences. March 2012, Vol.2. No 3 ISSN: 2222-6990

HERNANDEZ, M. C. Historia del Pensamiento en el Mundo Islámico. Madrid: Aliança Editorial, 2000.

HASANUZZAMAN, S.M. The Economic Relevance of the Sharia Maxims ( al Qawaid al Fiqhiyah). Saudi Arabia: Scientific Publishing Centre, 2007.

HASSANUZZAMAN, S.M. Economic Functions of an Islamic State- The Early Experience. Leicester, UK: The Islamic Foundation, 1991.

HASSAN, M. Kabirb and LEWIS, Mervin K. (Ed.). Handbook of Islamic Banking. British: MPG Books Ltd.: 2007. (Material Impresso)

HATHAWAY, Robert M. and LEE, Wilson (Ed.). Islamization and the Pakistani Economy. Washington: Woodrow Wilson International Center for Scholars, 2004.

HENKIN, Louis. International Law: Politics and Values. London: Martinus: Nijhoff Publishers, 1995.

HOLLINGER, Mathew E. Muqtada Al-Sadr: How to Desmilitarize Al-Sadr. Monterey: Naval PosGraduate School, Dissertação de Mestrado, 2009.

Islamic Trade, Export-Import Laws and Regulations Handbook. Volume 1, Strategic Informations and Laws for Selected Countries. Washington DC, USA: 2012 JAFAR, Al-Hadi. A realidade como ela é. São Paulo: Centro Islâmico do Brasil, 2007. JAFRI, S. Husain M. Origins and Early Development of Shi'a Islam. Islamic Republic of Iran: Ansariyan, 1989.

JOHNSON, Constance. Iraq: Legal History and Traditions. IN: The Law Library of Congress, LL File No 2004-208. Washington, 2004.

Islamic Commercial and Trade Law Handbook. Volume 1, Strategic Informationn and Regulation, Washington DC, USA. 2008.

Islamic Trade, Export-Import Laws and Regulations Handbook. Volume 1, Strategic Informations and Laws for Selected Countries. Washington DC, USA: 2012 
ISBELLE, Sami Armed. O Estado Islâmico e sua organização: sistema político, sistema econômico, sistema jurídico, sistema pena, conceito de Jihad. Rio de Janeiro: Qualitymark, 2007.

Islam: sua crença e sua prática. Rio de Janeiro: Azaan, 2003.

Brasil, 2005.

Islamic Banking $\quad$ Act, $1983 . \quad$ Disponível em $<$ http://www.bnm.gov.my/documents/act/en_ib_act.pdf $>$. Acesso em 24 de novembro de 2015.

JOMIER, Jaques. Islamismo: História e doutrina. Petrópolis, RJ: Vozes, 1992.

KHADDURI, Majid. Islamic Law of Nations: Shaibani's Siyar. Translated with and Indroduction, Note and Appendixes. Maryland: The John Hopkins Press, 1966.

KAMALI, M. H. Principles of Islamic Jurisprudence. Malasia: Islamic Texts Society, 2005)

KAMALI, M. H. Islamic Commercial Law: An Analysis of Futures and Options. Cambridge: Islamic Text Society, 2000.

KAMALI, Muhammad H. Uncertainty and Risk-Taking (Gharar) in Islamic Law, IN: International islamic University Malaysia Law Journal, Vol 7, nr.2 1998. p.199-216 KAHF, Dr. Monzer. The Islamic Economy: analytical study of the functioning of the Islamic economic system. USA: The American Trust Publication, 1993.

KARAM, Cristian. A Arábia Pré-Islâmica. IN: História Viva - Grandes Religiões 4Islamismo. São Paulo: Duetto Editorial, 2009. pp. 16-21

KNIGHT, Frank H. Professor Heimann on Religion and Economics. IN: The Journal of Political Economy. Vol. 56, № 6 ( Dec. 1948), pp. 480-497.

KURAN, Timur. The Long Divergence: How Islamic Held Back the Middle East. USA: Princeton University Press, 2011.

KURAN, Timur. Islam \&Mammon: The Economic Predicaments of Islamism. United States of America: Princeton University Press, 2004.

KURAN, Timur. Why the Middle East is Economically Underdeveloped: Historucal Mechanisms of Institutional Stagnation. IN: The Journal of Economic Perspectives, Vol. 18, No. 3 (Summer, 2004), pp. 71-90

KURAN, Timur. The economic system in contemporary Islamic thought: Interpretation and assessment IN: International Journal of Middle East Studies 18 (02), 135-164 
KURAN, Timur: On the notion of economic justice in contemporary Islamic thought. IN: International Journal of Middle East Studies 21 (02), 171-191

KURAN, Timur. The Provisiotn of Public Goods under Islamic Law: Origins, Impact and Limitations of Waqf System. IN: Law \& Society Review, Vol. 35, No. 4 (2001), pp. 841-898

KURAN, Timur. The Discontents of Islamic Economics Morality, IN: American Economic Review, 1996 p. 438-442

LARI, Sayyid Mujataba Musavi. The Fundations of Islamic Doctrine. Islamic Republic of Iran: Islamic Culture Development Office, 1988.

MALLAT, Chilli. Religious Militancy in Contemporary Iraq: Muhammad Baqer as-Sadr and the Sunni-Shia Paradigm. IN: Third World Quarterly, Vol.10, N. 2, Islam \& Politics (Apr., 1988), pp.699-729.

. The Renewal of Islamic La: Muhammad Baqer as-Sadr, Najaf, and the

Shi'i International. Cambridge Middle East International No 29. Kindle Edition Malik's Muwatta.. Hadith Book. Disponível em: <http://www.sultan.org/books/Muatta.pdf.> Acesso em: 23 novembro de 2015.

MANNAN, M.A. Islamic Economics: Theory and Practice. Pakistan: SH.Muhammad Ashaf, 1995. , KAHF, Monzer and AHMAD, Ausaf (Ed.). International Economic Relations from Islamic Perspectives. Saudi Arabia: Islamic Development Bank, 1992. MARR, Phebe. The Modern History of Iraq. United States: Westview Press, 1992.

MARTINS, Angela. A banca islâmica. Rio de Janeiro: Qualitymark, 2004.

MERAD, Ali. El Islam Contemporâneo. México: Fondo de Cultura Económica, 2001.

MIES, Françoise (org.). Biblia e economía: servir a Deus ou ao dinheiro. São Paulo: Eduções Loyola, 2003.

MEERA, Ahmed K. M. The Islamic Gold Dinar. IN: Selangor. Malaysia: Pelanduk Publications, 2002,

MOHIUDDIN, Yasmeen Niaz, Pakistan A Global Studies Handbook. U.S.A.: ABC-Clio, 2007.

MOTTAHEDEH, Roy Parviz.AS-SADR, Muhammad Baqir. Lessons in Islamic Jurisprudence. Oxford: Oneworld, 2003

MOMEN, Moojan. Na Introduction to Shi 'i Islam: The History and Doctrines of Twelver Shi'im. United States: Yale University Press, 1985. 
MUHAMMAD, Ibrahim T. Islamic Law of Business Transactions with Particular Reference to Sale of Goods. Nigeria. Thesis. June, 1998.

NAKASH, Yitzhak. The Shi'is of Iraq. United Kingdom: Princeton University Press, 1995.

NAQVI, Syed Nawab Haider. Ethics and Economics: an Islamic synthesis.UK: The Islamic Foundation, 1981.

NASR, Vali. Meccanomics: The March of the New Muslim Middle Class. Oxford: Oneworld, 2009.

NASSER, Salem H. "Seria a sharia a única fonte do direito islâmico nos países árabes?"

IN: Diálogo América do Sul-Países Árabes. Brasília: Funagipri, 2005.

PACE, Enzo. Sociologia do Islã: Fenômenos Religiosos e Lógicas Sociais. Petrópolis, RJ: Editora Vozes, 2005.

PAL, Izzud- Din. Islam and the economy of Pakistan: A Critical Analysis of Tradicional Interpretation. Pakistan: Oxford University Press, 2006.

PERRY, Frederick V. Shari'ah, Islamic Law and Arab Business Ethics. HEINONLINE: Citation: 22 Conn. Int'l L. 357 2006-2007 pp. 357-377

PHILIPP, Thomas. The Idea of Islamic Economics. IN: Die Welt des Islams, New Series, Bd. 30, Nr.1/4 (1990), pp. 117-139.

QUTB, Sayyid. Social Justice in Islam. Kuala Lumpur: Islamic Book Trust, 2000.

RAHMAN, Fazlur. O Islamismo. São Paulo: Arcadia, 1970.

REHMAN, Javaid. AHMEDOV, Aibek. Sources of Islamic Law. UK: Centre for Legal Education, 2011.

REDDEN, Sitta von. Money, Law and Exchange: coinage in the Greek Pollis, IN: The Journal of Hellenic Studies, Vol. 117 1997,p. 154-174.

RICHARDS, Alan. WATERBURY, John. A political economy of the Middle East.USA: Westview Press, 1996.

RIZVI, Sayyid Muhammad. Shi'ism Imamate \& Wilayat. Toronto: Sayyid Muhammad Rizvi, 1999.

RODINSON, Maxime. Islam and Capitalism. Great Britain: Penguin Books, 1977.

SCHÜLTZ, Rosalvo. Religião e Capitalismo: uma reflexão a partir de Feuerbach e Marx. Porto Alegre: EDIPUCRS, 2001.

SHANAHAN, Roger. Shi'a Political Development in Iraq: The Case of the Islamic Daw'a Party. IN: Third World Quaterly.Vol.25 No 5 (2004). pp.943-954. 
SHARAR, Haim, B. FISHELSON, Gideon. HIRSCH, Seev. Economic Cooperation and

Middle East Peace. London: Weidenfeld and Nicolson, 1989

SHARIATI, Ali. On the Sociology of Islam. Berkeley: Mizan Press, 1979 . Marxism and other Western Fallacies: an Islamic Critique. New Jersey:

Mizan Press, 1980.

SHIRKAH, Musharakah. Equity Based Modes of Financing. Disponível em $<$ www.learnislamicfinance.com $>$. AIMS.

SIDDIQI, Dr. Muhammad Nejatullah. The Economic Enterprise in Islam. Paquistão: Islamic Publications Ltd, 1988.

Some aspects of Islamic Economy. Delhi:

Markazi Maktaba Islami, 1981.

SIDDIQI, M.N. Principles of International Economic Relations in Islam, in: M.A. Mannan, Monzer Kahf e Ausaf Ahmad, International Economic Relations from Islamic Perspectives (Ed.) Jeddah, Saudi Arabia: IRTI, 1992.

SLUGLETT, Peter. SLUGLETT, Marion. F. Some Reflections on the Sunni/Shi'i Question Iraq. IN:Bulletin (British Society for Middle Eastern Studies). Vol. 5 N. 2 (1978). pp. 79-87.

SLUGLETT, Marion F. SLUGLETT, Peter. The Historiography of Modern Iraq. IN: The American Historical Rewiew. Vol.96. № 5 (Dec., 1991), pp.1408-1421.

TALEQANI, Seyyed Mahmood. Islam and Ownership. USA: Mazda publishers, 1983. THAUT, Laura. AHMED, Ajaz. An Islamic Perspective on Fair trade. United Kingdom: Islamic Relief Worldwide, 2009.

TRIP, Charles. Islam and the Moral Economy: the challenge of capitalism. USA: Cambridge University Press, 2006.

WILSON, Rodney Economic Development in the Middle East. London: Rooutledge, 1995.

VERNET, Juan. As Origens do Islã. São Paulo: Globo, 2004.

VICKERS, Michael. Fifth Century Cronology and Coins Decree, IN: The Journal Hellenic Studies, Vol. 116 1996, p. 171-174.

ZEKAVAT, Seid M. A blend of traditional Islamic Laws and modern Political Economy.USA: Xlibris Corporation, 2007. 
ANEXOS 


\section{MURABAHAH}

Core Clauses:

1. The Parties: 1) An Islamic Bank, as a first party, and

2) A purchase order, as a second party .

2- The second party orders the bank to buy described in the proforma

No date issued by for the price of

and to open an irrevocable letter of credit to the order and benefit of the supplier for the total price.

The second party promises to purchase the goods described above after they are purchased and

received by the Bank for the price mentioned in article

3. The first party gives, by this agreement, a proxy to the second party to work as an agent of the first party, in corresponding with the supplier, and in receiving the goods in the port and inspecting them, and in all relations with the insurance company, custom and other government and non-government agencies.

4. Upon receipt of shipping documents, the first party shall hand them to the second party as its agent. And the second party shall inspect the goods at the port and receive them on behalf of the first party. After receipt, the second party shall inform the first arty that, according to the promise, he purchases the goods for the price of which consists of the original purchase price of plus the mark up profit of the bank of The price is payable by the second party to the first party in the city of on the day of the year ; and he becomes totally responsible for the goods, including customs formalities, taxes, etc.

5. Collateral and Security: 
The second party delivers to the first party his shares of company as

collateral for the payment of the debt of due on that arises from this transaction duly endorsed to the name of the bank.

Other Clauses:

1. Number of original copies of the contract.

2. Determining the Court of competent jurisdiction over the contract.

3. Signing promissory notes.

Notes:

1. The collateral mentioned in clause 5 may be any valuables, mobile or immobile. It may also be an investment deposit with the financing bank, or a personal or bank guarantee.

2. Islamic Financial Institutions that are not licensed as banks may give their Murabahah through a licensed bank as a third party that acts as an agent of the financial institution. It may also be a guarantor of the beneficiary.

3. Sale price of Murabahah may be divided on several installments. 


\section{MUSHARAKAH}

Musharakah may take one of five versions:
A. Musharakah to the purchase orderer
B. (Normal) Musharakah
C. Musharakah with a promise to sell
D. Declining Musharakah
E. Buying Shares

\section{A. Musharakah to the purchase orderer}

Core Clauses:

1. The Parties:

1) An Islamic Bank, as a first partner, and

3) A purchase order, as a second partner

2. The second partner asks the bank to enter with him/her in a partnership on the basis of ..........(90\%) to the first partner and $10 \%$ to the second partner, to buy

as described in the proforma. No. date issued by for the price of , and

then to open an irrevocable letter of credit to the order and benefit of the supplier for the total price

of....................... The second partner promises to purchase, after actual receipt of the merchandise, the share of the first partner in the partnership for the price of ( $\cos \mathrm{t}+$ mark up).

3. The second partner will be responsible for all correspondence with the supplier, receiving the merchandise in the port, inspecting it and for all relations with the insurance company, custom and other government and non government agencies.

4. After receipt of shipping documents, the first partner shall inspect the goods at the port, and shall, 
according to the promise, inform the first partner that he purchases them for the price of (cost + mark up). This price is payable to the first partner in the city of on the day of the year And from the time of this purchase, the second partner alone becomes owner of the goods and responsible for all taxes, fees, custom duties, etc. related to them.

5. Collateral and Security:

The second partner delivers to the first partner his shares of company for use as collateral, duly endorsed to the name of the bank for the debt resulting after the purchase of the first partner's share in the partnership.

Other Clauses:

1. Number of original copies of the contract.

2. Determining the Court of competent jurisdiction over the contract.

3. Signing promissory notes.

\section{B. Musharakah (normal)}

Core Clauses:

1. The Parties: 1) An Islamic Bank, as a first partner, and

2) A legal or natural person, as a second partner

2. Statement of objective of Musharakah, such as "The Second Partner approached the bank to enter into a partnership agreement to operate the factory of located at ..... which is owned by the second partner, for a period of

3. A Musharakah is hereby established between the two partners as follows:

- the first partner provides a capital of US\$ for the purpose of using it as an operational capital for the factory - the second partner provides the net worth of his factory as represented in the balance sheet, as amended and accepted by the two partners, in the amount of

4. The second partner shall manage this Musharakah in the usual and customary manner and to the best interest of the partnership within the scope of a mutually agreed upon 
policy and strategy. However, the first partner shall appoint one of its employee, as a representative in the partnership. The representative has the full right to inspect accounts, books and records of the partnership at any time, and to place a reservation or an objection on any managerial acts he sees unfit with the best interest of the partnership.

5. All banking transactions of the partnership shall be exclusively effected in, with and through the first partner.

6. The second partner pledges to supply the bank with quarterly reports and to consult with its

representative before taking any decision in important matters and to take a written approval

before disbursement, or pledge of disbursement of any amount exceeding US\$

7. The distribution of profits shall be as follows:

- .........\% to the second partner as compensation for his managerial efforts

- the remainder shall be distributed according to the shares in capital, as mentioned in Article 3 of this agreement and any losses shall solely be distributed in proportion to share in capital as in

Article 3 too.

8. The duration of this Musharakah is (one) year, i.e., until the day of the month of ............ of the year ................. only; and a balance sheet shall be prepared at the end of this period and sufficient assets of the partnership shall, by then, be liquidated to pay the share of the first partner plus/minus profit or loss.

9. The second partner puts under the full authority of the first partner his (securities, real estates, etc.) as a guarantee to be used only in case of any damage caused by neglect or transgression by the second partner.

Other Clauses:

1. Number of original copies of the contract.

2. Determining the Court of competent jurisdiction over the contract. 


\section{Musharakah with a promise to sell (applies to fixed assets)}

Core Clauses:

1. The Parties: 1) An Islamic Bank, as a first partner, and

3) A legal or natural person, as a second partner

2. The objective of partnership is to construct (purchase) a (airplane, ship, building,

etc.) in the specification mentioned in Annex I; and operate it for profit.

3. A Musharakah is hereby established between the two partners as follows:

- the first partner provides $90 \%$ of the capital or US\$

- the second partner provides $10 \%$ of the capital or US\$

- in case the cost of the assets to be constructed (or purchased) exceeds the amount of US\$ the increment shall be contributed by the parties in the same proportion.

4. The second partner shall manage this Musharakah in the usual and customary manner and to the best interest of the partnership within the scope of a mutually agreed upon policy and strategy. However, the first partner shall appoint one of its employee, as a representative in the partnership. The representative has the full right to inspect accounts, books and records of the partnership at any time, and to place a reservation or an objection on any managerial acts he sees unfit with the best interest of the partnership.

5. All banking transactions of the partnership shall be exclusively effected in, with and through the first partner.

6. The second partner pledges to supply the bank with quarterly report and to consult with its representative before taking any decision in important matters and to take a written approval before disbursement, or pledge of disbursement of any amount exceeding US\$

7. The distribution of profits shall be as follows: $\%$ to the second partner as compensation for his managerial efforts 
- the remainder shall be distributed according to the share in capital mentioned in Article 3 of this

agreement and any losses shall be distributed in proportion to share in capital as in Article 3 too.

8. The duration of this Musharakah is ...... (e.g., seven) years.

9. The first partner promises to sell his share in the partnership, at the end of its duration, to the second partner for a price of US\$

10. The second partner puts under the full authority of the first partner his (securities, real

estates, etc.) as a guarantee to be used only in case of any damage caused by neglect or transgression by the second partner.

Other Clauses:

1. Number of original copies of the contract.

2. Determining the Court of competent jurisdiction over the contract.

3. The second partner shall deposit in a special investment account with the first partner $\%$

of the total of his managerial and capital profits for the purpose of accumulating an amount sufficient for buying the first partner out. This deposit shall be invested on Mudharabah basis as a long-term Mudharabah fund with a distribution of profit as follows:

- $10 \%$ to the bank as a Mudhareb

$-90 \%$ to the depositor

\section{Declining Musharakah (applies to fixed assets)}

Core Clauses:

1. The Parties: 1) An Islamic Bank, as a first partner, and

2) A legal or natural person, as a second partner

2. The objective of partnership is to construct (purchase) a (airplane, ship or building in 
the specification mentioned in Annex I and operate it for profit.

3. A Musharakah is hereby established between the two partners as follows:

- the first partner provides $90 \%$ of the capital or US\$

- the second partner provides $10 \%$ of the capital or US\$

- in case the cost of the assets to be constructed (or purchased) exceed the amount of US\$ the increment shall be contributed by the parties in the same proportion.

4. The second partner shall manage this Musharakah in the usual and customary manner and to the best interest of the partnership within the scope of a mutually agreed upon policy and strategy. However, the first partner shall appoint one of its employee, ............................. as a representative in the partnership. The representative has the full right to inspect accounts, books and records of the partnership at any time, and to place a reservation or an objection on any managerial acts he sees unfit with the best interest of the partnership.

5. All banking transactions of the partnership shall be exclusively effected in, with and through the first partner.

6. The second partner pledges to supply the bank with quarterly report and to consult with its representative before taking any decision in important matters and to take a written approval before disbursement, or pledge of disbursement of any amount exceeding US\$

7. The distribution of profits shall be as follows:

$\%$ to the second partner as compensation for his managerial efforts

- the remainder shall be distributed according to the share in capital mentioned in Article 3 of this

agreement and any losses shall be distributed in proportion to share in capital as in Article 3 too.

8. The duration of this Musharakah is nine years. 
9. The first partner promises to sell, out his share, $10 \%$ of the total capital of the partnership to the second partner at the end of each accounting year for the amount of US\$ , payable at the time of signing the sale contract.

Other Clauses:

1. Number of original copies of the contract.

2. Determining the Court of competent jurisdiction over the contract.

3. The second partner shall deposit in a special investment account with the first partner $\%$

of the total of his managerial and capital profits for the purpose of accumulating an amount sufficient for buying the shares promised for sale at the end of each year. This deposit shall be invested on Mudharabah basis as a long term Mudharabah fund with a distribution of profit as follows:

- $10 \%$ to the bank as a Mudhareb

$-90 \%$ to the depositor

\section{E. Buying Shares}

This is done by means of sale contract if shares are bought from organized or non-organized markets; or by means of agreement to establish a company or corporation. 


\section{MUDHARABAH}

Mudharabah may take one of four versions:
A. (Normal) or simple Mudharabah
B. Mudharabah with a promise to sell
C. Declining Mudharabah
D. Buying Non-voting Shares

\section{A. Simple (Normal) Mudharabah}

Core Clauses:

1. The Parties: 1) An Islamic Bank, as a Rabb al Mal (funds owner) who shall be called the bank, and

2) A legal or natural person, as a Mudhareb (working partner)

2. Statement of objective of Mudharabah, such as: "The Mudhareb approached the bank to enter into a Mudharabah agreement to trade in textile, through import and distribution in the location of which is owned by the Mudhareb, for a period of

3. A Mudharabah is hereby established between the two parties as follows:

a) the Rabb al Mal provides a capital of US\$ for the purpose of using it as a principal for the Mudharabah

b) the Mudhareb takes full charge of managing this Mudharabah for the purpose of maximizing its

profit and to liquidate all its properties by its closing date. All that with full honesty and maximum loyalty to its objective. He shall maintain separate, inclusive and comprehensive accounts for the Mudharabah. 
4. The Rabb al Mal has the full right to inspect accounts, books and records of the Mudharabah at any time, and to place a reservation on any managerial acts he sees unfit with the best interest of the Mudharabah.

5. All banking transactions of the Mudharabah shall be exclusively effected in, with and through the bank.

6. The Mudhareb pledges to supply the bank with quarterly reports. And it is understood that he shall use his expertise and facilities of his business in the fulfillment of the objectives of this Mudharabah.

7. The profit is defined as any amount in excess of the principal after liquidating all properties of the Mudharabah.

The distribution of the profit shall be as follows:

a) .........\% to the Mudhareb

b) .........\% to the Rabb al Mal

c) Any losses shall solely be born by Rabb al Mal.

8. The duration of this Mudharabah is (one) year, i.e., until the day of the month of of the year only; and the Mudhareb is required, by the end of this period, to liquidate all assets of the Mudharabah.

Other Clauses:

1. A collateral may be added to be used only in case of loss resulting from Mudhareb's negligence or violation of conditions of contract. 
2. Certain limitation may be added in matters related to geographical boundary of the business and to kinds of merchandise. By the same token, a Mudharabah may be left very general or restricted to a specific or single transaction.

3. A condition allowing the Mudhareb to mix own and/or others' funds with fund of Mudharabah, may also be added.

4. Number of original copies of the contract.

5. Determining the Court of competent jurisdiction over the contract.

\section{B. Mudharabah with a promise to sell (applies to fixed assets)}

Core Clauses:

1. The Parties:

1) An Islamic Bank, as a Rabb al Mal, called the bank, and

2) A legal or natural person, as a Mudhareb

2. The objective of the Mudharabah is to contribute $90 \%$ to the construction (purchase) of a ................. (airplane, ship, building, etc.) in the specification mentioned in Annex I; and operate it for profit.

3. A Mudharabah is hereby established between the two parties as follows:

a) the bank provides $90 \%$ of the total cost or US\$ this is defined as the Mudharabah principal

b) the Mudhareb provides $10 \%$ of the cost or US\$ to be mixed with the Mudharabah principal 
c) in case the cost of the assets to be constructed (or purchased) exceeds the amount of US\$ the increment shall be contributed by the parties in the same proportion d) the total construction (purchase) of above mentioned assets and their operation for profit is

hereby called the project.

4. The Mudhareb shall manage this Mudharabah in the usual and customary manner and to the best interest of the Mudharabah within the scope of this contract. He is required to maintain separate, inclusive and comprehensive accounts for this project of which the Mudharabah makes 90\%. However, the Rabb al Mal shall has the full right to inspect accounts, books and records of the Mudharabah at any time, and to place a reservation on any managerial acts he sees unfit with the best interest of the Mudharabah.

5. All banking transactions of the Mudharabah shall be exclusively effected in, with and through the bank.

6. The Mudhareb pledges to supply the bank with quarterly report.

7. The distribution of profits shall be as follows:

a) $10 \%$ (ten percent) of the profit (loss) of the project shall be to the second party as a reward on his

contribution to the capital of the project $b$ ) the remaining $90 \%$ (ninety percent) is defined as

the Mudharabah outcome and shall be distributed according to the following:

- .......\% to the Rabb al Mal, and

- .......\% to the Mudhareb.

- In case of loss, all this $90 \%$ of losses of the project shall be born by Rabb al Mal.

8. The duration of this Mudharabah is (e.g., seven) years.

9. The Rabb al Mal promises to sell his share in the project, at the end of the Mudharabah duration, to the Mudhareb for a price of US\$ This sale shall be effected by means of a separate contract at that time. 
Other Clauses:

1) A collateral may be added to be used only in case of loss resulting from Mudhareb's negligence or violation of conditions of contract.

2) Certain limitation may be added in matters related to geographical boundary of the business and to kinds of merchandise. By the same token, a Mudharabah may be left very general or restricted to a specific or single transaction.

3) A condition allowing the Mudhareb to mix own and/or others' funds with fund of Mudharabah, may also be added.

4) Number of original copies of the contract.

5) Determining the Court of competent jurisdiction over the contract.

6) The Mudhareb shall deposit in a special investment account with the bank $\%$ of the total of his managerial and capital profits for the purpose of accumulating an amount sufficient for buying the Rabb al Mal out. This deposit shall be invested on Mudharabah basis as a long-term Mudharabah fund with a distribution of profit as follows:

- $10 \%$ to the bank as a Mudhareb

$-90 \%$ to the depositor

\section{Declining Mudharabah (applies to fixed assets)}

Core Clauses:

1. The Parties: 1) An Islamic Bank, as a Rabb al Mal, called the bank, and

2) A legal or natural person, as a Mudhareb

2. The objective of the Mudharabah is to contribute $90 \%$ to the construction (purchase) of a ................. (airplane, ship, building, etc.) in the specification mentioned in Annex I; and operate it for profit.

3. A Mudharabah is hereby established between the two parties as follows: 
a) the bank provides $90 \%$ of the total cost or US\$ this is defined as the Mudharabah principal

b) the Mudhareb provides $10 \%$ of the cost or US\$ to be mixed with the Mudharabah principal

c) in case the cost of the assets to be constructed (or purchased) exceeds the amount of US\$ the increment shall be contributed by the parties in the same proportion

d) the total construction (purchase) of above mentioned assets and their operation for profit is

hereby called the project.

4. The Mudhareb shall manage this Mudharabah in the usual and customary manner and to the best interest of the Mudharabah within the scope of this contract. He is required to maintain separate, inclusive and comprehensive accounts for this project of which the Mudharabah makes 90\%. However, the Rabb al Mal shall has the full right to inspect accounts, books and records of the Mudharabah at any time, and to place a reservation on any managerial acts he sees unfit with the best interest of the Mudharabah.

5. All banking transactions of the Mudharabah shall be exclusively effected in, with and through the bank.

6. The Mudhareb pledges to supply the bank with quarterly report.

7. The distribution of profits shall be as follows:

a) $10 \%$ (ten percent) of the profit (loss) of the project shall be to the second party as a reward on his

contribution to the capital of the project

b) the remaining $90 \%$ (ninety percent) is defined as the Mudharabah outcome and shall be

distributed according to the following: 
- .......\% to the Rabb al Mal, and

- .......\% to the Mudhareb.

- In case of loss, all this $90 \%$ of losses of the project shall be born by Rabb al Mal.

8. The duration of this Mudharabah is nine years.

9. The Rabb al Mal promises to sell, out his share, $10 \%$ of his shares in the project to the Mudhareb at the end of each accounting year for the amount of US\$ payable each year at the time of signing the sale contract.

Other Clauses:

1) A collateral may be added to be used only in case of loss resulting from Mudhareb's negligence or violation of conditions of contract.

2) Certain limitation may be added in matters related to geographical boundary of the business and to kinds of merchandise. By the same token, a Mudharabah may be left very general or restricted to a specific or single transaction.

3) A condition allowing the Mudhareb to mix own and/or others' funds with fund of Mudharabah, may also be added.

4) Number of original copies of the contract.

5) Determining the Court of competent jurisdiction over the contract.

6) The Mudhareb shall deposit in a special investment account with the bank $\%$ of the total of his managerial and capital profits for the purpose of accumulating an amount sufficient for buying the Rabb al Mal out. This deposit shall be invested on Mudharabah basis as a long-term Mudharabah fund with a distribution of profit as follows:

- $10 \%$ to the bank as a Mudhareb

- $90 \%$ to the depositor 


\section{Buying Non-voting Shares (Mudharabah Shares)}

This is done by means of sale contract if shares are bought from organized or nonorganized markets; or by means of agreement to establish a company or corporation. Keeping in mind that certain laws (for instance, in Bahrain) allow companies to issue non-voting shares, which are, in fact, Rabb

al Mal shares in a Mudharabah. 


\section{Complete Code on Islamic Civil Law ${ }^{495}$}

Article 1: "Matters are determined according to intention"

Article 2: "In contracts effect is given to intention and meaning and not words and forms"

Article 3: "Certainty is not dispelled, (does not dispel caused), by doubt.

Article 4: "It is a fundamental principle that a thing shall remain as it was originally."

Article 5: "Things which have been existence from time immemorial shall be left as they were."

Article 6: "Injury cannot exist from the time immemorial."

Article 7: "Freedom from liability is a fundamental principle."

Article 8: "Non-existence is a fundamental presumption attached to intervening (transitory) attributes."

Article 9: "Judgment shall be given in respect to any matter, which has been proof at any particular time, unless the contrary is proved."

Article 10:"It is fundamental principle that any new event shall be regarded as happening at the time nearest to the present."

Article 11: "In principles, word shall be construed according their real meaning."

Article 12: "No attention shall be paid to inferences (implication) in the face of an explicit statement."

Article 13: "Where there is a text there is no room for interpretation."

Article 14: "A thing established contrary to the Qiyas can not be used as an analogy for other things."

Article 15: "One legal interpretation does not destroy another."

Article 16: "Hardship begets facility."

Article 17: "Latitude should be afforded in the case of difficulty."

Article 18: "Injury may not be met by injury."

Article 19: "Injury is to be repaired."

Article 20: "Necessity renders prohibited things permissible."

Article 21: "Necessity is determined by the extent thereof."

\footnotetext{
495 Islamic Trade, Export-Import Laws and Regulations Handbook. Volume 1, Strategic Informations and Laws for Selected Countries. Washington DC, USA: 2012
} 
Article 22: "Whatever is permissible owing to some excuse ceases to be permissible with the disappearance of what excuse."

Article 23: "When a prohibition is removed the thing to which such prohibition attached reverts to its former status of legality."

Article 24: "An injury cannot be removed by a similar injury."

Article 25: "A private injury is tolerated in order to ward off a public injury."

Article 26: "Severe injury is removed by lesser injury."

Article 27: "In the presence of two evils, the one whose injury is greater is avoided by the commission of the lesser."

Article 28: "The lesser of evils is preferred."

Article 29: "Repelling an evil is preferable to securing benefit."

Article 30: "Injury is removed as far as possible."

Article 31: "Need, whether a public or private nature, is treat as necessity."

Article 32: "Necessity does not invalidate the right of another."

Article 33: "When it is forbidden to take a thing it is also forbidden to give it."

Article 34: "When it is forbidden to perform an act it is also forbidden to request to its performance."

Article 35: "Custom is authoritative."

Article 36: "Public usage is conclusive and action must be taken accordance therewith." Article 37:"A thing that is customary to regard as impossible is considered to be impossible in fact."

Article 38: "It is undeniable that rules of law vary with change in time."

Article 39: "The original (real) meaning is to be regarded in favor of that established by custom."

Article 40: "Effect is only given to custom where it is so regular occurrence or when universally prevailing."

Article 41: "Effect is given to what is of commom occurrence, not to what happens infrequently."

Article 42: "A matter recognizes by custom is regarded as if stipulated by agreement."

Article 43: "A matter recognized customary amongst merchant is regarded as if agreed upon between them."

Article 44: "A matter established by custom is like a matter established by a legal text." Article 45: "When prohibition and exigency conflict, preference is given to prohibition." 
Article 46: "An accessory which is attached to an object in fact is also attached to it in law."

Article 47: "An accessory to an object cannot be dealt with separately."

Article 48: "The owner of a thing in the absolute ownership is also the owner of the things indispensable to the enjoyment of such thing."

Article 49: "If the principle fails, the accessory also fails."

Article 50: "A thing which has been discharged or annihilated cannot be restored."

Article 51: "When a thing becomes void, the thing contained in it also becomes void."

Article 52: "When the original fails it is restored to its substitute."

Article 53: "A thing which is not permissible in itself, may be permissible as an accessory."

Article 54: "A thing is not permissible by way of commencement may be permissible by way of continuance."

Article 55: "Continuance is easier than commencement."

Article 56: "A gift becomes complete by delivery."

Article 57: "Management of citizen's affairs is dependent upon public welfare."

Article 58: "Private trusteeship is more effective that public trusteeship."

Article 59: "A word should be construed as have some meaning, rather that disregarded."

Article 60: "When the real meaning cannot be applied, the metaphorical sense may be used."

Article 61: "If no meaning can be attached to a word it is regarded altogether."

Article 62: "A reference to a part of an indivisible thing is regarded as a reference to the whole."

Article 63: "The absolute is construed in its absolute sense, provided that there is no proof of a restrict meaning either in the explicit text or by implication."

Article 64: "A description with reference to a thing present is of no consequence, but the contrary is the case if such thing is not present."

Article 65: "A question is considered to have been repeated in the answer."

Article 66: "No statement is imputed by to a man who keeps silence, but silence is Notantamount to a statement where is a necessity for speech."

Article 67: "In obscure matters the proof of a thing stands in the place of such a thing." Article 68: "Correspondence resembles conversation." 
Article 69: "The recognized signs of a dumb person take the place of a statement by word of mouth."

Article 70: "The word of and interpreter is accepted in every respect."

Article 71: "No validity is attached to conjecture which obviously tainted by error."

Article 72: "No argument is admitted against supposition based upon evidence."

Article 73: "No weight is attached to fancy."

Article 74: "A thing established by proof is equivalent to a thing established by visual inspection."

Article 75: "The burden of proof is on him who alleges; the oath on who denies."

Article 76: "The object of evidence is to proof what is the contrary to the apparent fact."

Article 77: "Evidence is an absolute proof that it affects third person; admission is relative proof in that it affects only the person making such admission."

Article 78: "A person is bound by his own admission."

Article 79: "Contradiction and proof are incompatible, but this does not invalidate a judgment."

Article 80: "Failure to establish the principal claim does not imply failure to establish a claim subsidiary thereto."

Article 81: "Anything dependent upon a condition precedent is established on the happening of the condition."

Article 82: "A condition must be fulfilled as far as possible."

Article 83: "Promises dependent upon a condition precedent are irrevocable."

Article 84: "The enjoyment of a thing is the compensating factor for any liability attaching thereto.

Article 85: "Remuneration and liability do not run together."

Article 86: "Liability is an obligation accompanying gain."

(That is to say, a person who enjoys the benefits of a thing must submit to the disadvantage attaching thereto.)

Article 87: "The burden is in proportion to the benefit and the benefit to the burden."

Article 88: "The responsibility for an act falls upon the author thereof; it does not fall upon the person ordering such act, provided that such person does not compel the commission thereof."

Article 89: "In the presence of the direct author of an act and the person who is the cause thereof, the first alone is responsible therefor." 
Article 90: "Legal permission is incompatible with liability."

Article 91: "Liability lies in the direct author of an act, even though acting unintentionally."

Article 92: "No liability lies on a person who is the cause of an act unless he has acted intentionally."

Article 93: "No liability attaches in connection with injury caused by animals of their own accord."

Article 94: "Any order given for dealing with the property of others is void."

Article 95: "No person may deal with the property of another without such person's permission."

Article 96: "No person may take another person's property without legal cause."

Article 97: "Any change in the cause of the ownership of a thing is equivalent to a change in that thing itself."

Article 98: Any person, who hastens the accomplishment of a thing before its due time, is punished by being deprived thereof."

Article 99: 'If any person seeks to disavow any act performed by himself, such attempt disregarded." 


\section{Informações Sobre os Entrevistados}

\section{Professor Dr.Seyed Hadi Arbabi}

B.A. of Theoretical Economics from Mofid University-Iran

M.A. of Economics sciences from Tarbiat Modares University-Iran

$\mathrm{PhD}$. of Economics sciences (international economics) from Tarbiat Modares UniversityIran

graduated from seminary school of Hawzeh of Qom-Iran

\section{Professor Dr. Seyed Abbas Musaviyan}

B.A. of Economics from Tehran University-Iran

M.A. of Economic sciences from Beheshti University-Iran

$\mathrm{PhD}$. of Jurisprudence in Economics from Islamic college of Hawzeh -Iran

graduated from seminary school of Hawzeh of Qom-Iran

\section{Professor Dr. Muhammad Javad Tavakoli}

B.A. of Islamic theology from Islamic college of Hawzeh -Iran

M.A. of Economics from Imam Khomeini College -Iran

M.A. of Philosophy of Economics from Erasmus University- Netherlands PhD. of Philosophy of Economics from Erasmus University- Netherlands

graduated from seminary school of Hawzeh of Qom-Iran

\section{Professor Dr.Muhammad Ali Hajidehabadi}

B.A. of Law from Mofid University-Iran

M.A. of Law \& criminology from Mofid University-Iran

PhD. of Law \& criminology from Tehran University -Iran

graduated from seminary school of Hawzeh of Qom-Iran

\section{Professor Dr.Shahryar Shojaeipour}

B.A. of History from Imam Sadiq University-Iran

M.A. of Islamic History from Imam Sadiq University-Iran

$\mathrm{PhD}$. of Islamic History from Imam Sadiq University-Iran 


\section{Dr. Morteza Muhammadi}

B.A. of Law from Mofid University-Iran

M.A. of Private Law from Mofid University-Iran

PhD. of Private Law from Mofid University -Iran

graduated from seminary school of Hawzeh of Qom-Iran

\section{Professor Dr. Ali Asghar Hadavinia}

B.A. of Theoretical Economics from Tehran University-Iran

M.A. of Theoretical Economics from Mofid University-Iran

$\mathrm{PhD}$. of Theoretical Economics from Mofid University -Iran

graduated from seminary school of Hawzeh of Qom-Iran

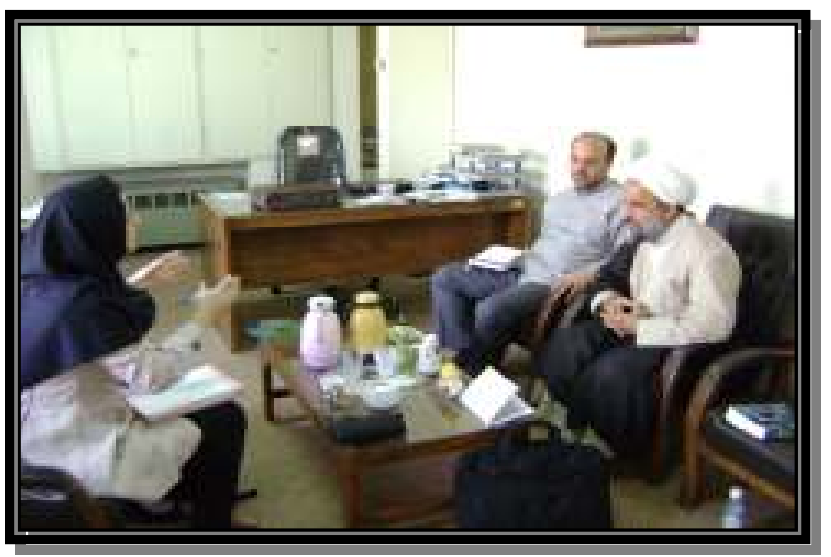

Dr. Ali Asghar Hadavinia

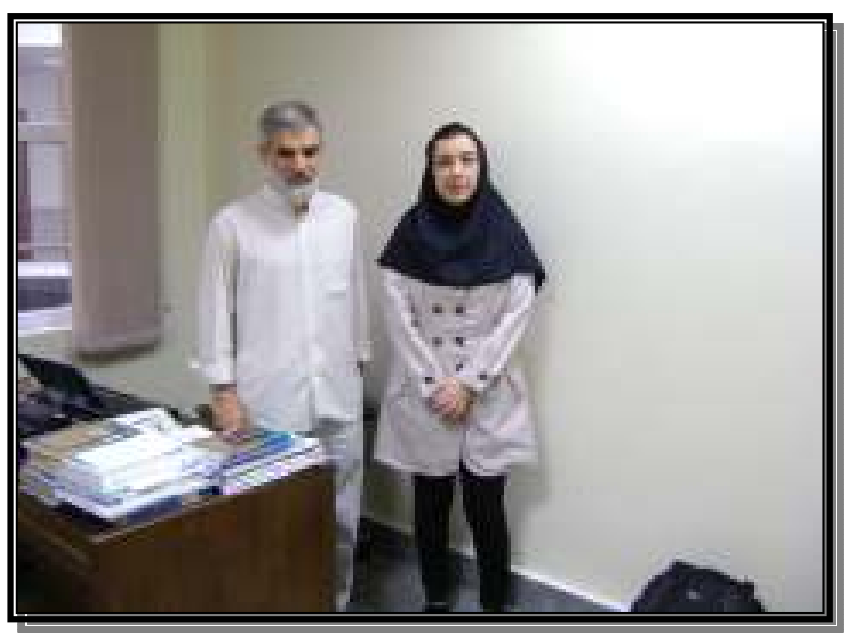

Dr.Seyed Hadi Arbabi 


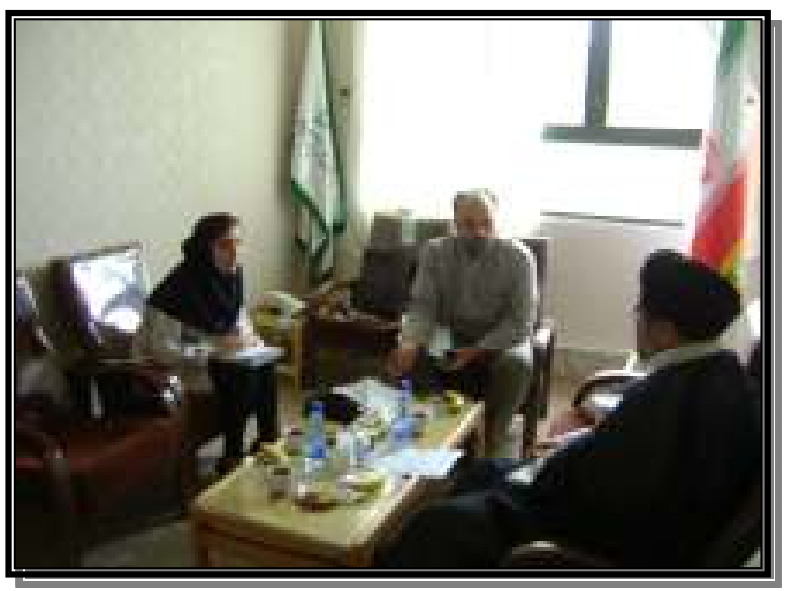

Dr. Seyed Abbas Musaviyan

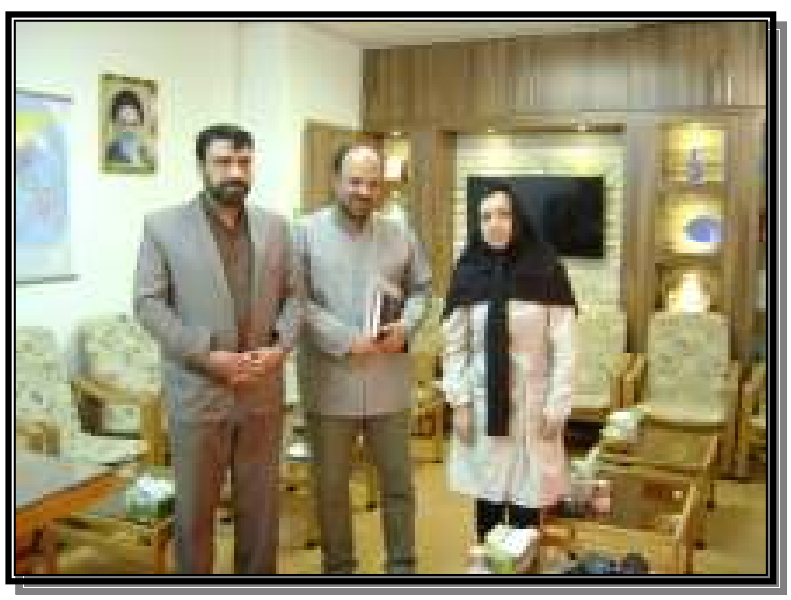

Com o diretor da Universidade foi debatido a questão dos efeitos nocivos das cirses econômicas na área criminal.

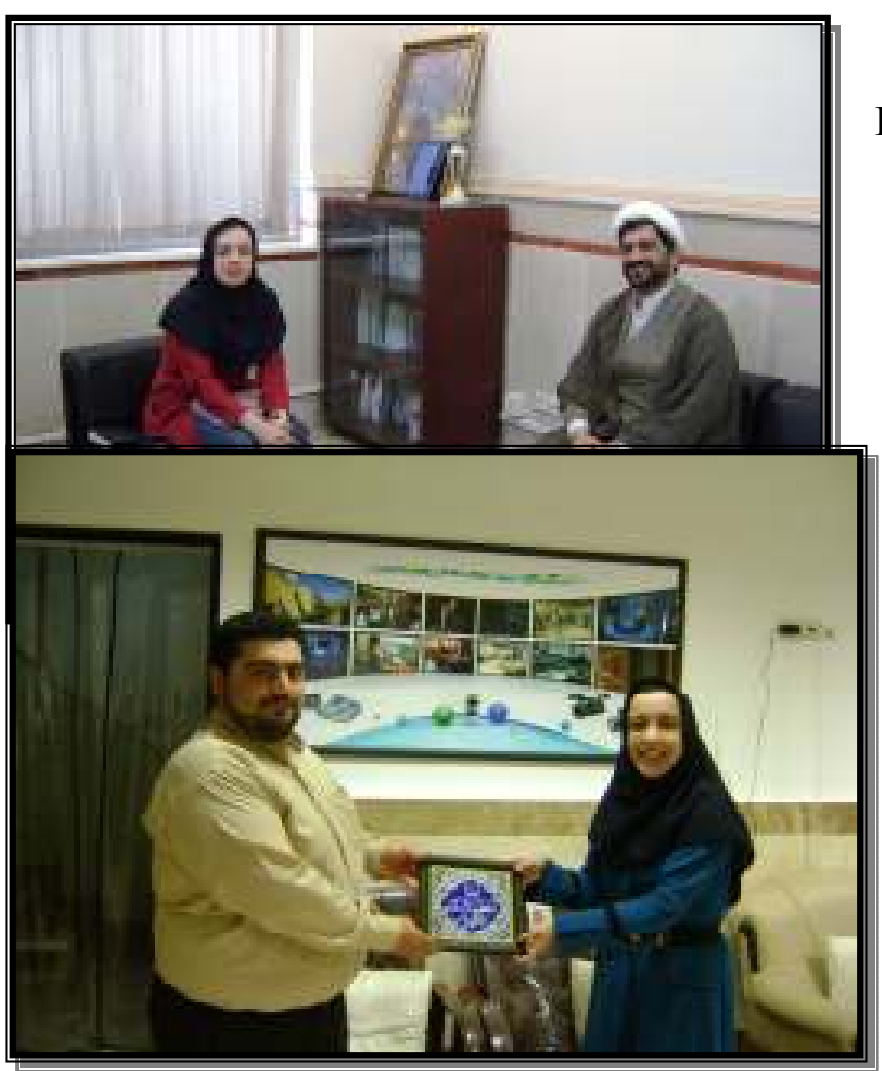

Dr. Morteza Muhammadi

Entrevista dada a TV no Irã sobre a tese apresentada e a visão de Muhammad Baqir Assadr. 


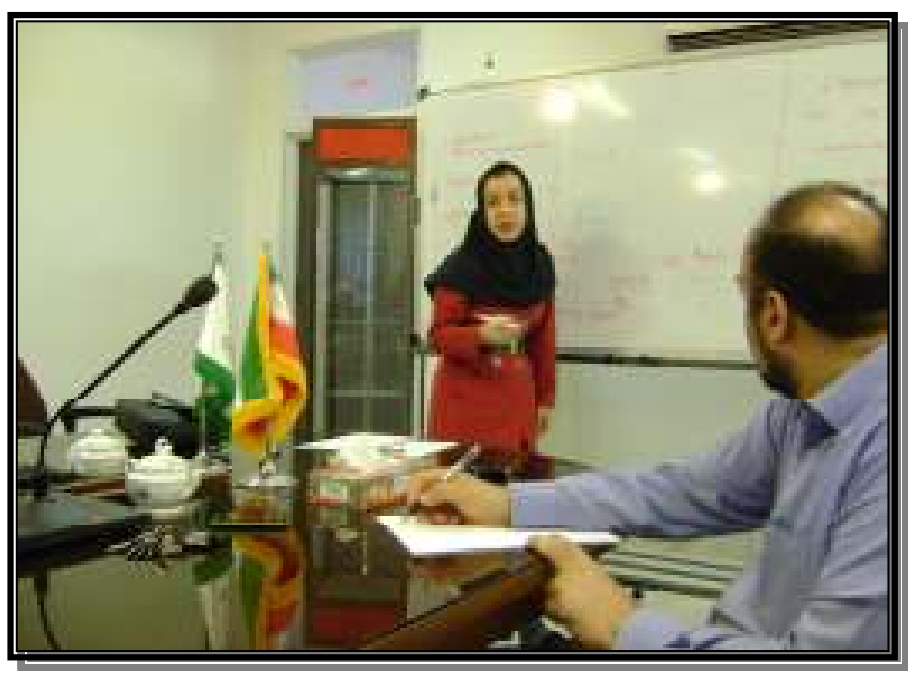

Ministrei aulas em duas Universidades em Qom sobre a História Economica do Brasil

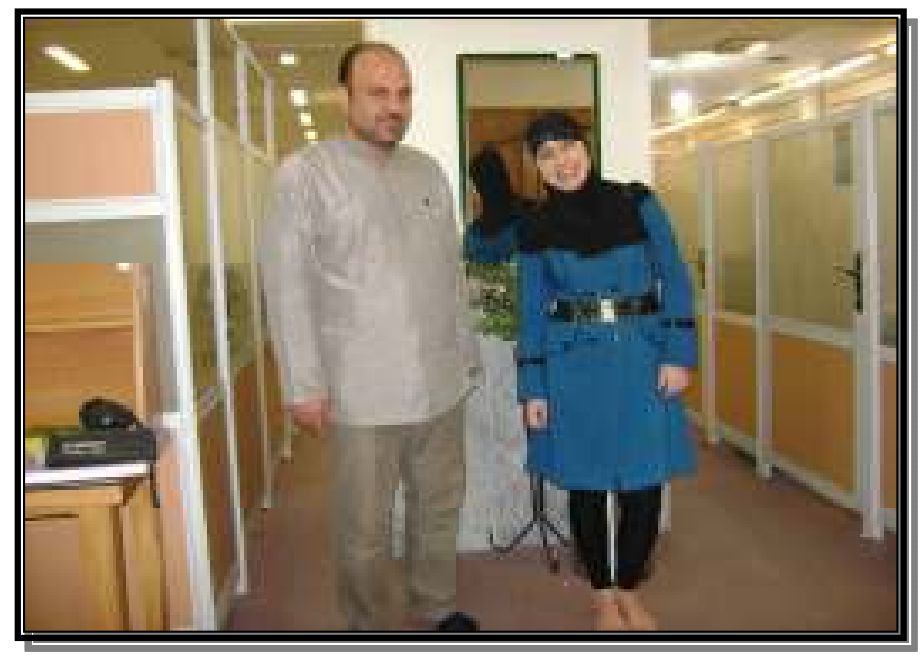

Dr.Shahryar Shojaeipour 
جكيده شهيد فرز انه، آية الله، سيد محمد باقر صدر از بزركترين متفكران و عالمان دينى معاصر شيعه است كه در حوزه

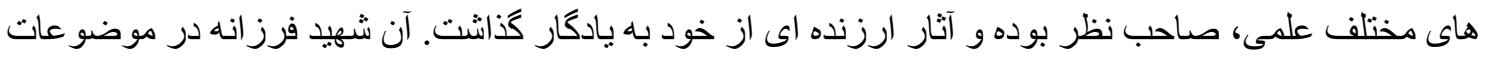
كوناكون فلسفى، منطقى، اصولى، فقهى و اقتصادى نظريه هاى بديع و مههى داشت كه به حق در خور \حسين و

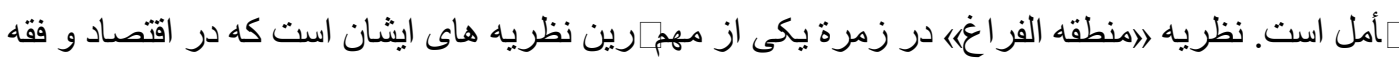
سياسى و ... كار آمد و ر اهكثاست. در اين مقاله ضمن نقد و بررسى اين نظريه به زمينه هاى بيشين اين نظريه ميان عالمان اهل سنت و شيعه نيز اشاره خو اهد شد. لازم است بار ديكر ضمن ارج نهادن به مقام علمى رفيع اين

شهيد فرز انه و بزرخى نظريه منطقه الفر اغ يادآور شويم. نقد اين نظريه به هيج وجه از اهميت اهميت و ارجمندى آن نمى كاهد.

مقدمه. شهيد سيد محمد صدر از دانشور ان و فقيهان برجسته معاصر شيعه است كه از علوم مختلف اسلامى آكاهى عميق

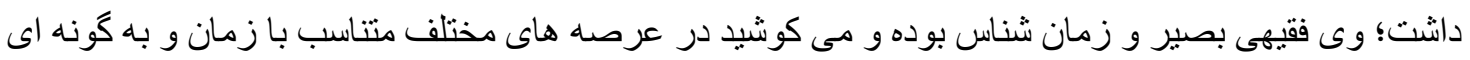

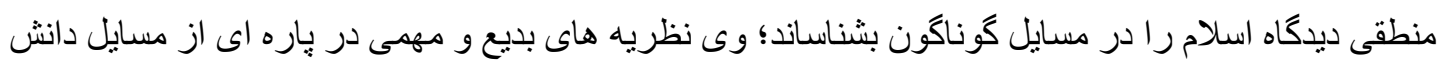
هايى از قبيل فلسفه، منطق، اصول، فقه و اقتصاد داشت. كه به حق در خور ستايش است. نظرية منطقه الفراغ

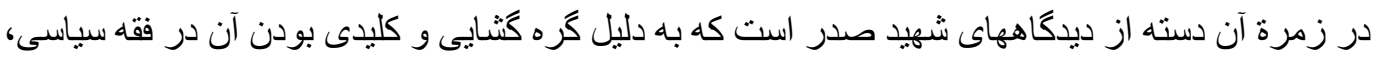
اقتصادى مسأله نقش زمان و مكان در اجتهاد و بسيارى از مسايل نويديد،ـوجه خاص محققان را جلب كرده است اين مقاله در بيى آن است كه نظرية منطقه الفر اغٔر ا بهه ويزه از رواية المباط آن با احكام حكومتى و مصلحت كزارش و نقد كند؛ بر ایى بررسى وطحليل اين نظريه آكاهى از نكته هاى زير سودمند خو اهد بود.

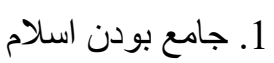
شهيد صدر معتقد بود اسلام دينى است جامع و برلمام شؤون زندكى آدمى برّو مى افكند و طرحى كامل و جامع بر اى بهتر زيستن و جگحونه زندگى كردن دارد ؛ وى در اين باره مى نويسد:

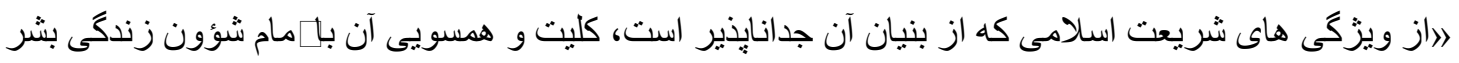
است. اين همسويى و كليتـنها از طريق استقر ار و كنكاش احكام اسلام به دست نيامده؛ بلكه در مصادر و منابع

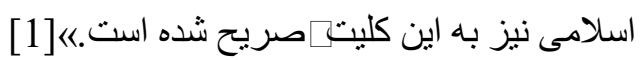

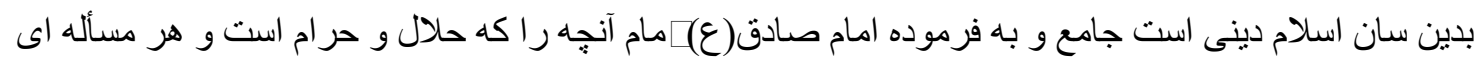
را كه بشر در زندگى خود با آن روبرو مى شود، اسلام حكمشان را بيان كرده است.

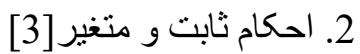

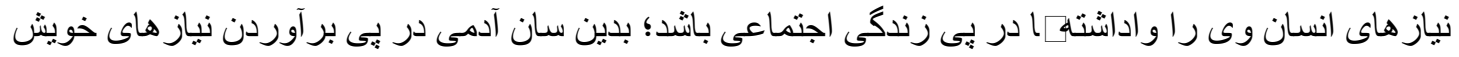
است و آنها جز در بستر جامعه قابل دستيابى نبست، از اين رو به زندگى دسته جمعى روى مى آورد؛ شهيد صدر در اين باره جنين مى نويسد:

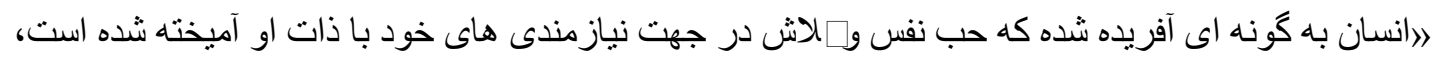

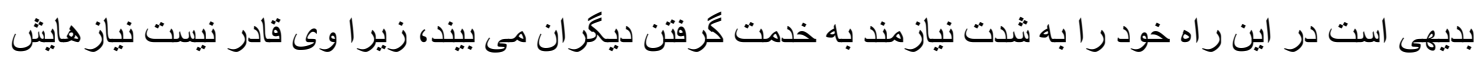


را جز از راه همكارى با ديكر انسان هابر آورد. از اين رو روابط اجنماعى از دامن نياز هاز اده شده و با

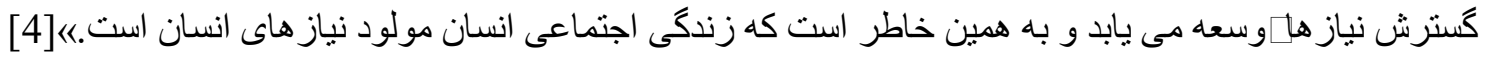
نياز هاى انسان دو دسته است؛ نباز هاى ثابت و نياز هاى متغير . نياز هاى ثابت يا همان نياز هاى اساسى كه امكان

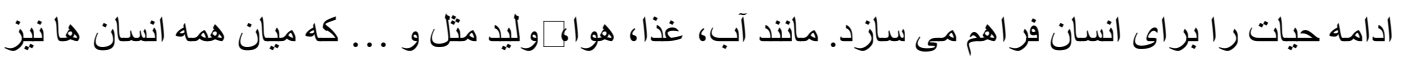
مشترك است.

نياز هاى متغير نياز هايى است كه انسان در صحنه زندكى بها]دريج با آنها روبرو مى شود و هر قدر انسان

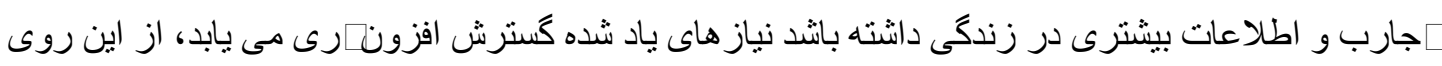

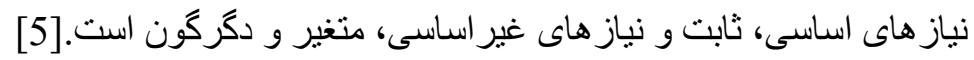

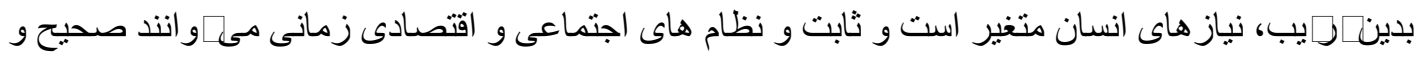

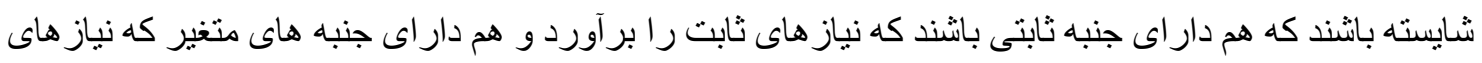

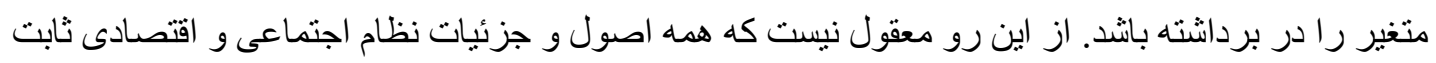

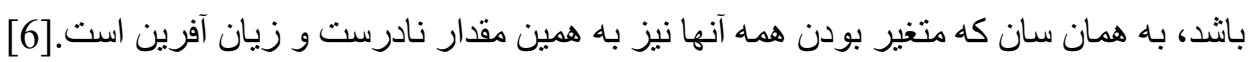
استاد شهيد، سيدمحدباقر صدر معتقد است اسلام نيز به اين حكم عقل عمل كردهو قو انين خود را در دو بخش

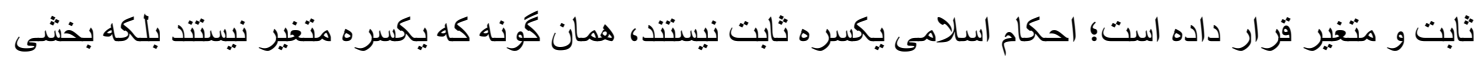

از آنها ـ كه قسمت اساسى رلشكيل مى دهد - احكام ثابت است و بخش ديكر متغير و متطور كه مطابق با دكركونى ها وظغيير اوضاع و احوال انعطاف يذيرند؛ احكام ثابت در قو انين اسلام در واقع باسخى است كه نظام

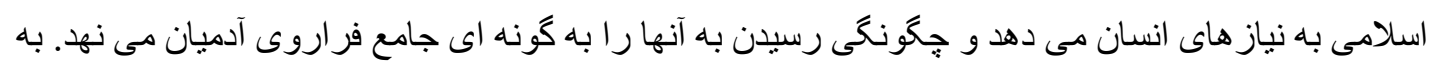

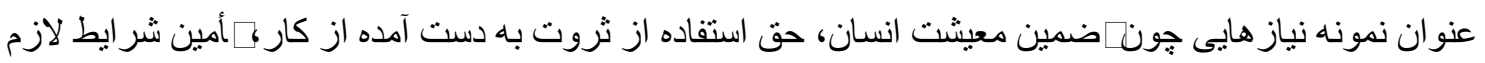

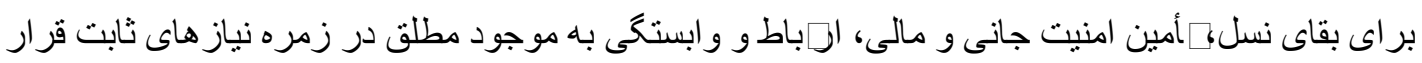

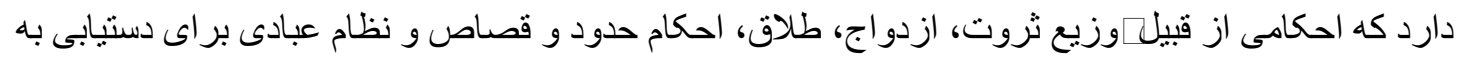
آنها وضع شده اند. متقابلاً كرو هى از احكام، ثابت و دائمى نيستند و همواره در حاله غيير وطحول اند و آنها احكامى است كه اسلام به ولى امر مسلمين اجازه داده استـا بر طبق مصلحت هاو نياز هاى متغير جامعها و در لهر

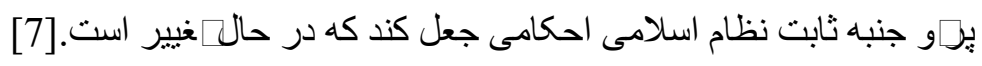
ولايت فقيه و حكومت اسلامى جنى از ويزگى هاى نظريه شهيد صدر دربارة مصلحت آن است كهو وى رابطة نشخانكى ميان مصلحت و و لايت مى داند؛ وى در زمرة فقيهانى است كه بهـشكيل حكومت اسلامى اعتقاد و دلبستخى خاصى داشته و جان خود را را براى شكوفا شدن آن در عراق نثار كرده است. در اين جا مجال آن نيست كه ديدكاه ايشان درباره و لايت فقيه و حكومت وضفاوت هاى نظريه ايثان با نظريه امام

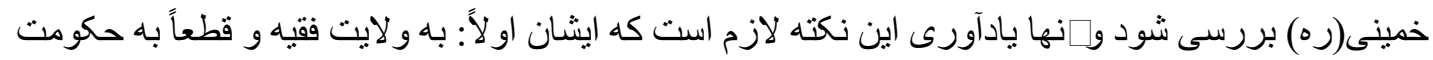
اسلامى اعتقاد دانت و ثانياً: و لايت و مصلحت را دار اى رابطة وثيقى مى دانست. آن شهيد فرز انه به مناسبت

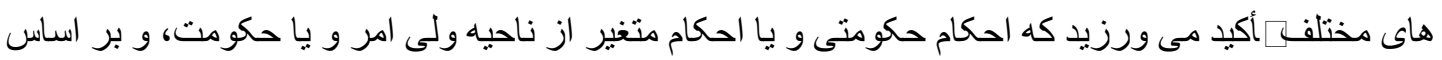
مصلحت بر ایى حقق عدالت صادر شود. بدين سان مى [وان مسأله مصلحت را در زمرة مسايل مربوط به و ولايت و حكومت دانست. [8] 
مصلحت ضابطه احكام حكومت

نتيجه مقدمات ياد شده آن است كه اسلام دينى است جامع و براى دنباو آخرت، معيشت و معنويت مردم برنامه

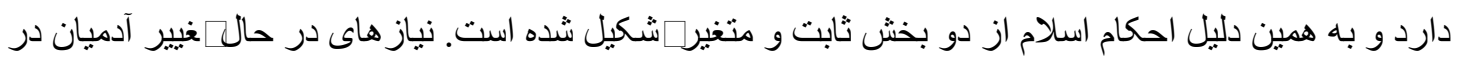
بستر احكام متغير أمين مى شود و و لايت و حكومت درّعيين اين احكام سهم اساسى را دارد و ولى امر بادر

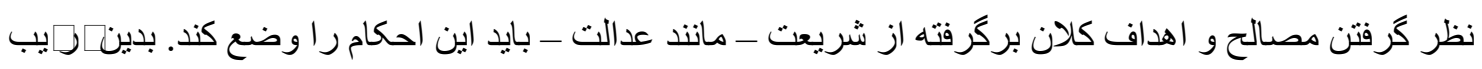
مصلحت مبناى صدور احكام حكومنى است، اين نكته در آثار مختلف شهيد صدر آمده است. در اين جا جند نمونه از مو اردى را كه ايثان مصلحت را مبناى احكام حكومت مى داند، نقل مى كنيم.

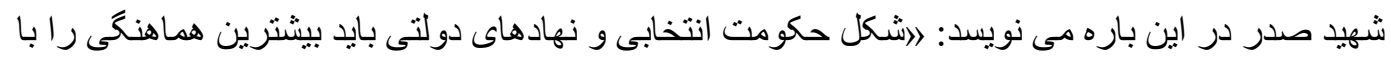

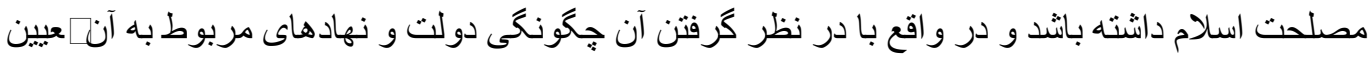

شود. بِ از انتخاب حكومت، حكو مت منتخب بايد بريايه مصالح مسلمانان، اعم از مصلحت هاى مادى و معنوى

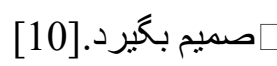
بدين سان شهيد صدر معتقد است دولت انتخابى جامعه اسلامى در احكام و قو انينى كه بر اى اداره جامعه وضع

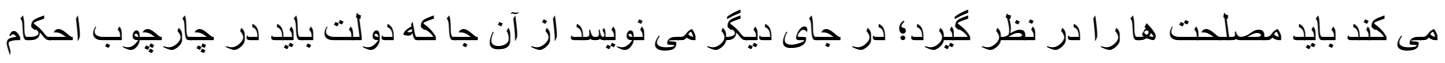
شرعى و فتاوى فقيهان عمل كند و هركاه فقيهان در فتو اهاى خود اختلاف نظر داشته باثند ولى امر يا مجلس انتخاب شده از اهل حل و عقد[11] (مجلس شور ایى اسلامى) مى بايد هر فتو ايى را كه مطابق با مصلحت

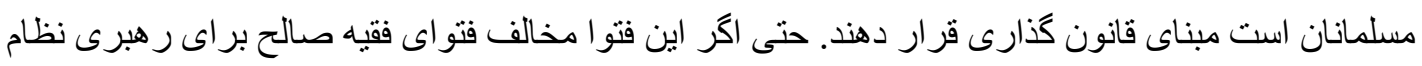
باشند.

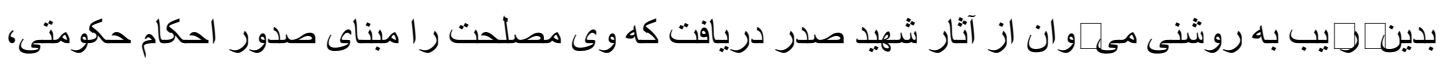
مى دانست جها عيين آن به عهده ولى امر باشد و يا بر عهده مجلس منتخب نهاده شود. زمينه هاى نظريه منطقه الفراغ به اعتقاد بسيارى از فقيهان اهل سنت مبتكر نظريه مصالح مرسله امام مالك بود، و فقيهان مالكى در مقام بهره

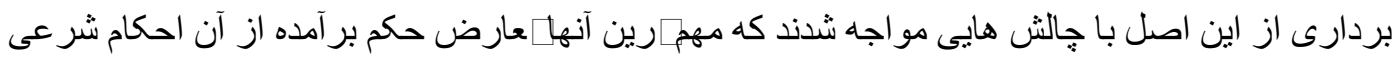
استنباط شده از ديكر ادله شر عى است، و از جاره جويى هاى آنان بر ایى حل اين مشكل آن بود كه كفتند مصالح مرسل نبايد با هيتج حكم شرعى و يا ادلة آن مخالف باشد. برخى از مفسران اهل سنت درطهنير اين آيه شريفه 》اطيعوا الله و اطيعوا الرسول و اولى الامر منكم) با مشكل

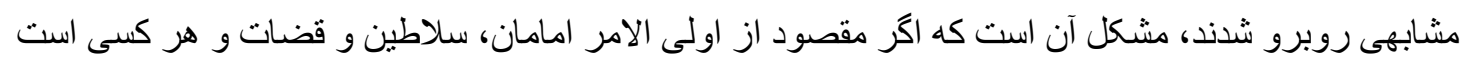

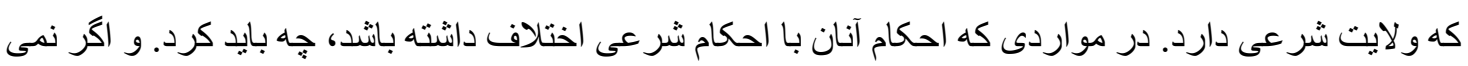

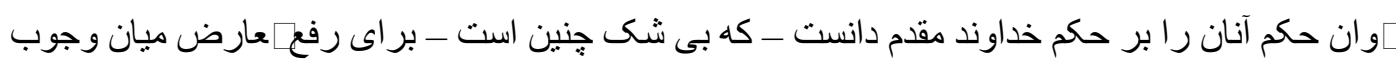

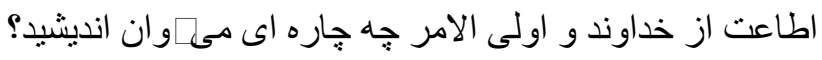

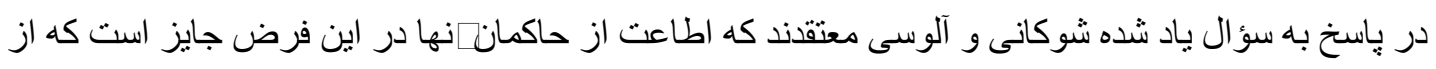

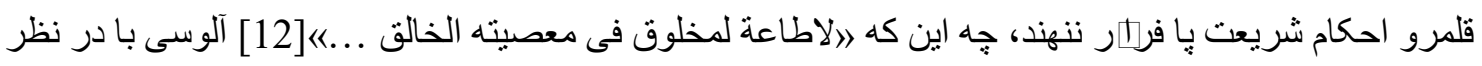
كرفنت اختلافات اهل سنت در اين باره كه برخى از آنان در حوزه مباحات بر ایى ولى امر حق دخالت فئ فائلند و 
برخى آن را ممنو ع كرده و كرو هى آن را منوط به مصلحت عمومى دانسته اند و يّ ازهأكيد بر عدم لزوم اطاعت در احكام مخالف با شرع، مى نويسد: 》آيا عدم لزوم اطاعت از آنان قلمرو مباحات را نيز در بر مى كيرد؟ در اين باره اختلاف نظر است. برخى كفته

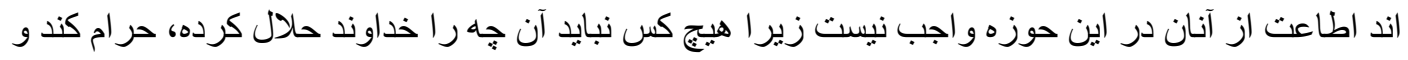
برخى كفته اند در حوزه مباحات نيز اطاعت واجب است. 》حصكفى《) از كسانى است كه به صر احت اين را كفته اند. برخى از محققان شافعى مذهب نيز كفته اند اطاعت از امر و نهى امامجا زمانى كه به حر امى فرمان ندهد و اجب است. و برخى ديكر كفته اند هركاه امر او از مصلحت نشأت نكرفته باشد، اطاعت از وى در باطن و اجب نيست، اما آن دسته از اوامر او كه برخاسته از مصلحت باثد اطاعت ظاهرى و باطنى از آنها واجب [13].«... است

در سخنان آلوسى به انحصار وجوب اطاعت از امام در قلمرو مباحات به كونه اى آثفته و مبهم اثـاره، شدهو

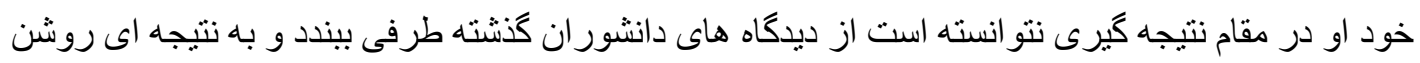
دست يابد.

در ميان فقهاى شيعه شيخ انصارى در بحث از شروط مطلبى دارد كه مه لو ان آن را به سرنخى بر ایى نظريه منطقه الفر اغ دانست؛ در آن جا شيخ به اين نظر فقها، انشاره مى كند كه هر شرط مخالف شرع به دليل رو اياّى از قبيل 》 الآّرطاً احُلّ حر اماً و حرم حلالاً ) بى اعتبار است. شيخ در اين جا سؤ ال مهمى را مطرح مى كند كه جه شرطى حلال را حر ام و يا حر ام را حلال مى كند؟ براى منل اكر انسان نذر كند عمل مباحى را انجام دهد و يا

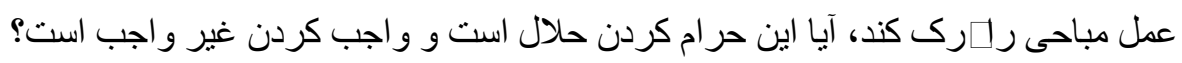

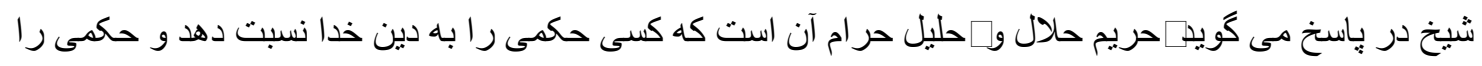

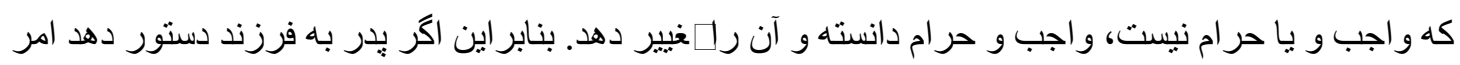

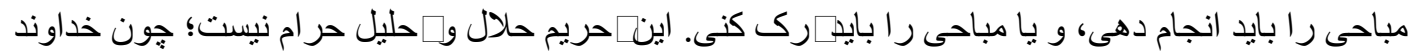
فرموده است اطاعت از يدر واجب است. اما يدر نمى لو اند به فرزندش امر كند كه حكمى را كهو واجب يا حر ام

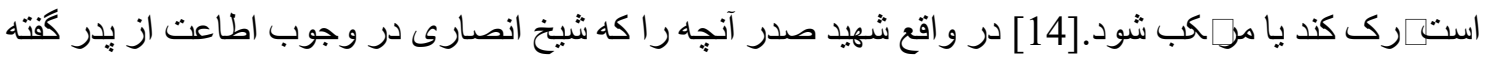
است دربارة وجوب اطاعت از ولى امر مطرح كرده است. منطقه الفر اغ در سخنان نائينى

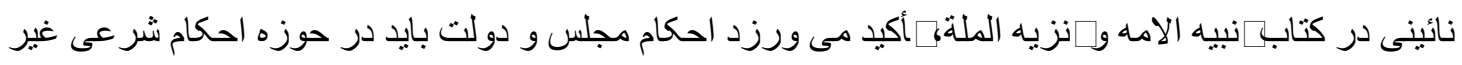

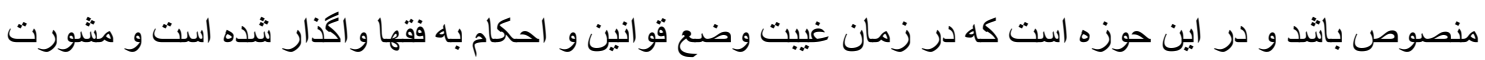
با متخصصان در مجلس شور اى اسلامى در اين قلمرو صحيح است و در احكام منصوص موضوعيت ندارد؛ در آنجا بايدططبيق شود و در اينجا وضع وطعيين، وى در اين باره جنين مى نويسد: |بدان كه مجموع وظايف ر اجعه به نظم و حفظ مملكت و سياست امور امت - خو اه دستورات اوله متكفله اصل دستور العمل هاى راجعه به وظايف نو عيه باثد، يا ثانويه متضمنه مجاز ات بر مخالفت دستور ات اوليه - على كل

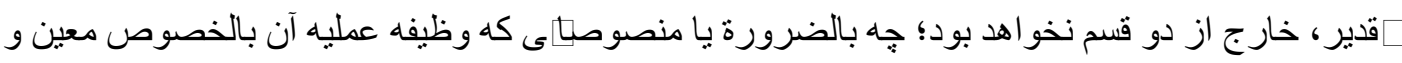

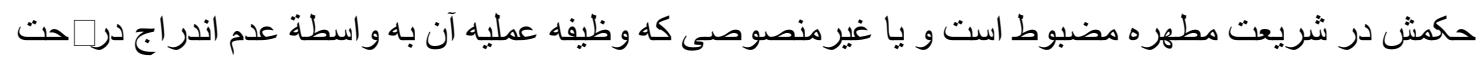
ضابط خاص و ميز ان مخصوص غيرمعين و به نظر و \رجيح ولى نوعى موكول استها. 


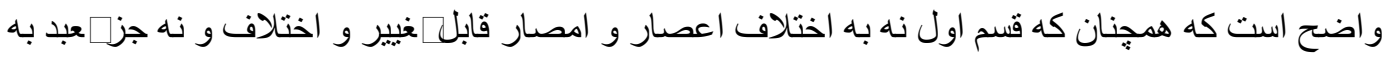
منصوص شرعى الى قيام الساعة وظيفه و رفتارى در آن متصور طو اند بود، قسم ثانى همَابع مصالح و

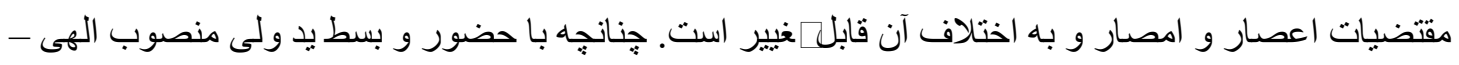
عزّ اسمه - حتى در ساير اقطار هم به نظر وطارجيحات منصوبين از جانب حضرَش - صلوات الله عليه موكول است، در عصر غييت هم به نظر و \رجيحات نو اب عام يا كسى كه در اقامه وظايف مذكوره عمن له له

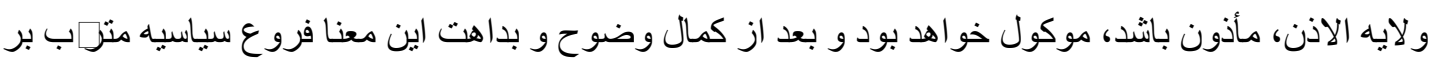
اين اصل بدين، كريب است...ب[15]

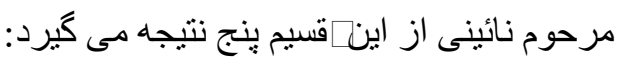

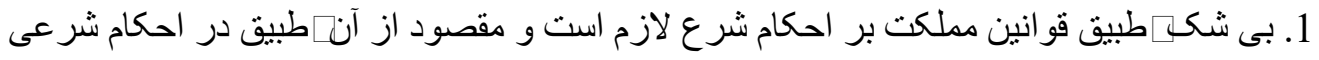

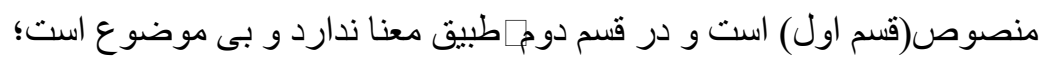

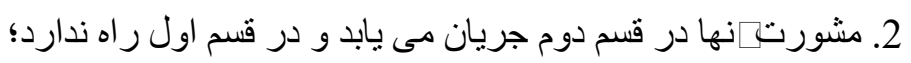

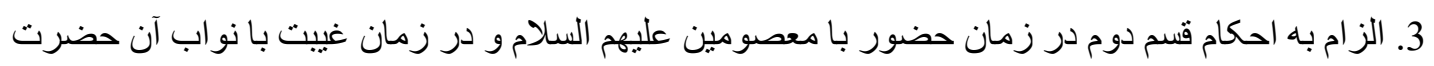

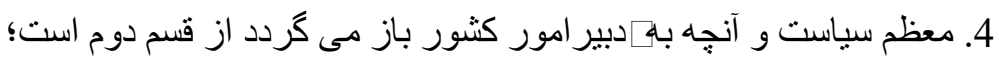
5. در قسم دوم؛ يعنى حوزه احكام غير منصوص و مباح، رعايت مصلحت لازم است و در و اقع اين حوزه، قلمرو احكام متغير است؛ نائينى در اين باره جنين مى نويسد:

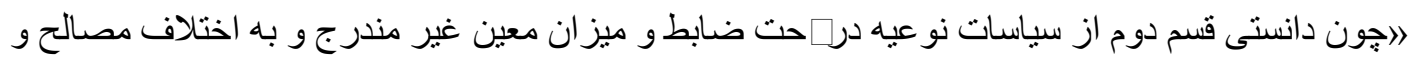
مقتضيات مختلف. و از اين جهت در شريعت مطهره غيرمنصوص و به مشورت و صرجيح من له ولاية النظر

موكول است. بِ البته قو انين راجعه به اين قسم، نظر به اختلاف مصالح و مقتضباش بله اختلاف اعصدار

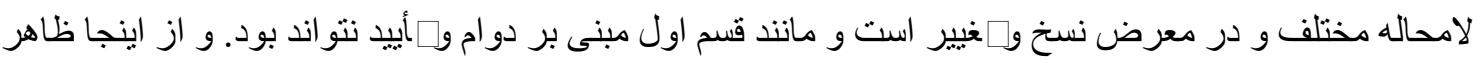

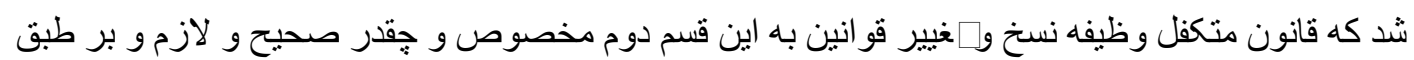
وظيفه حسبيه است.ب[16] شكوفايى نظريه منطقه الفر اغ بسيارى از عناصر نظريه شهيد صدر در 》امنطقه الفر اغن) آن كونه كه خواهد آمد در مطالب نائينى آمده است و شهيد صدر در و اقع آن را يخته و سخته كرده و عالمانه به بسطو كسترش و سامان دهى آن برداخته است.

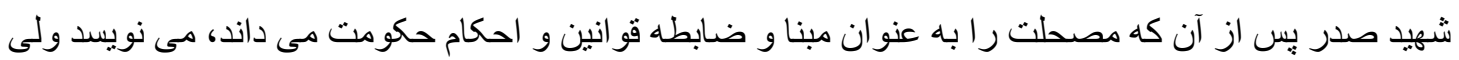

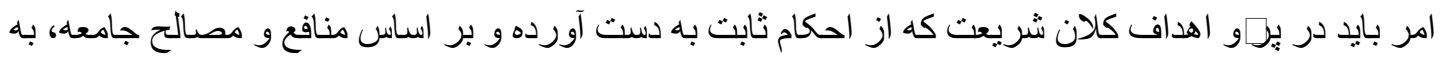

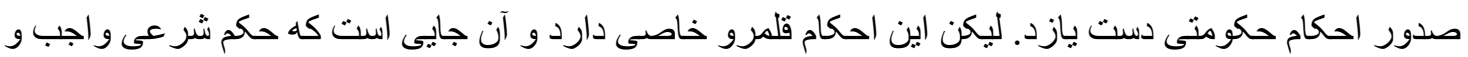

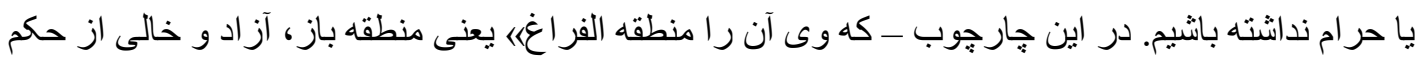
الز امى مى نامد - احكام متغير بر طبق مصالح منافع جامعه از ناحيه ولى امر جعف مى شوند؛ اين منطقه خالى

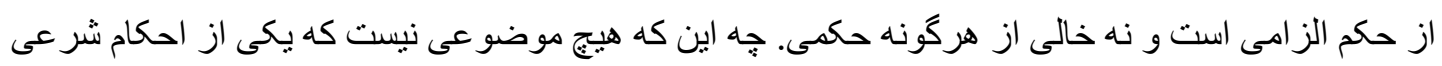
بدان علق نغيرد. 


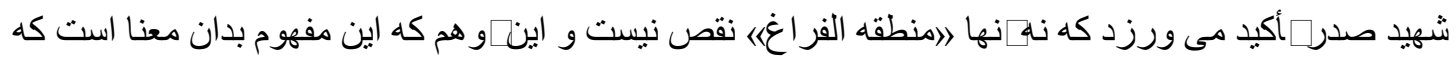
اسلام بر اي برخى از موضو عات حكمى بيش بينى نكرده است، بسى بى جا است، جه اين كه منطقه الفراغ -

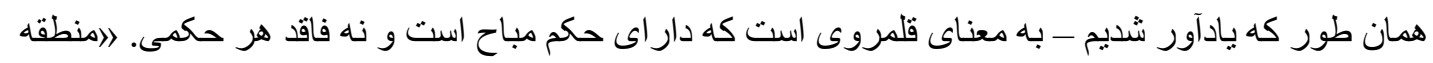

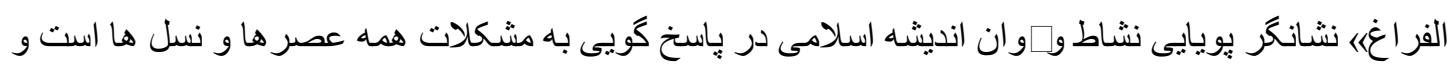

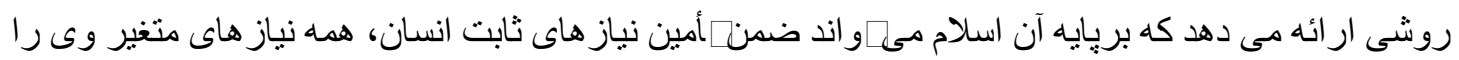
بر آورده سازد. شايان ذكر است كه كرجه مشروح]رين]وضيح در اين باره در كتاب 》اقتصادنا《) و دربارة مسايل اقتصادى آمده است،[18] اما شهيد صدر در برخى از آثار خود به صر احت آن را به همه احكام اجتماعى، سياسى و اقتصادى بـرهي

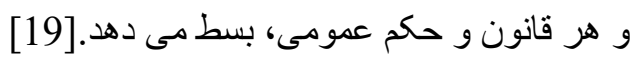
شهيد صدر افزون برضأكيد بر عدم مخالفت احكام صادر شده از سوى حكومت با احكام شر عى و قانون اساسى

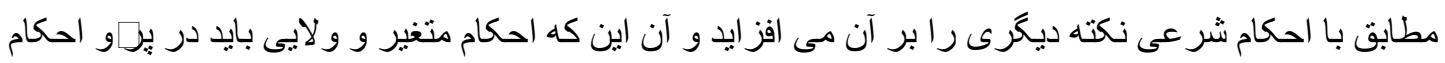

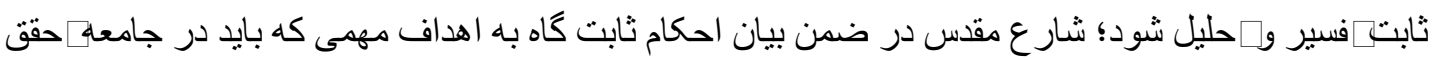

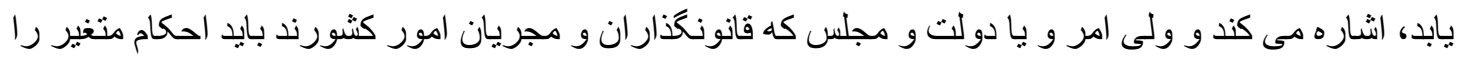
به كَونه ایى سامان داده و به آن سمت و سو بخشند كه زمينة اهداف شارع كه در ضمن جعل احكام ثابت بيان شده، بر آورده شود؛ به عنوان مثال خداوند متعال در آية 》فيئى) كه بيانكر يك حكم دايمى است با جمله (اكى بـى

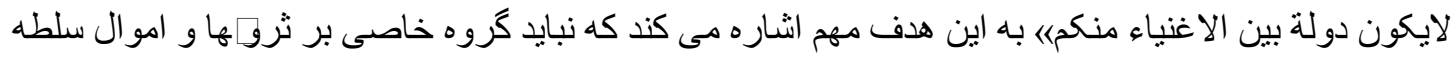

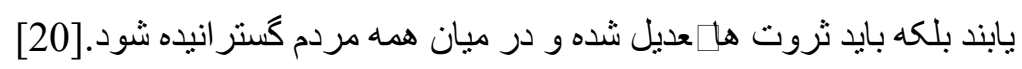

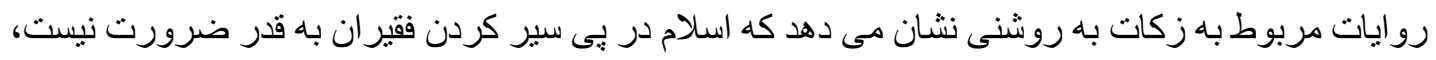

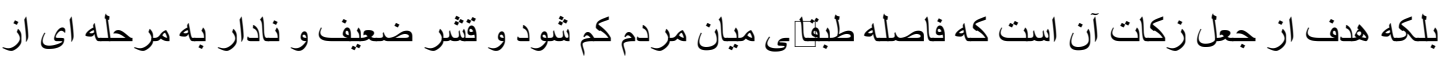
امكانات و رفاه كه در خور شأن آنان است، دست يابند. [21] آباىى از قرآن نيز نشانكر آن است كه ارزش هايى از قبيل عدالت، بر ابرى و ايجاد روحية بر ادرى ميان مؤمنان از اهداف مهم اسلام است[22] كه ولى امر بايد در جعل احكام متغير مصلحت هاى مردم را در برّو آنها بسنجد و با اين سنجش و ارزيابى به جعل احكام حكو منى دست يازد.

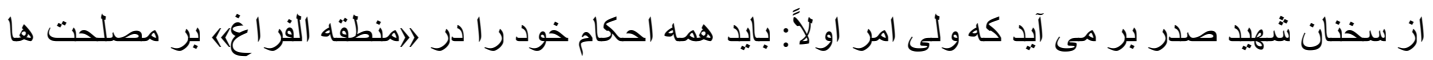

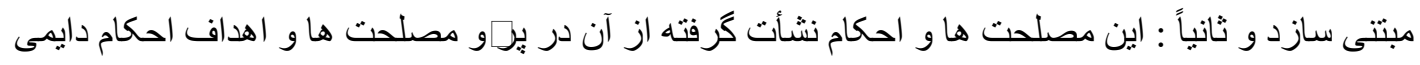

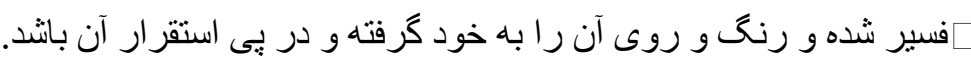
مرجع شخيص مصلحت يبش از اين آورديم كه يرسازى منطقه خالى و آزاد (منطقه الفراغ) را شار ع مقدس بر ایىأمين نياز هاى متغير جامعه و حكومت اسلامى، قرار داده است و اشاره كرديم كه اين مسؤوليت در زمان حضور بر دوش بيامبر و

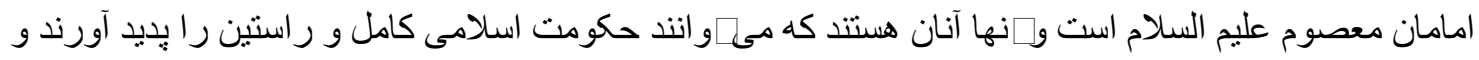
اين وظيفه را در زمان غييت بر دوش ولى امر و با مجلس كذاشته اند. در اين بخش ياسخ دقيق مار به اين برسش را يـى مى كيريم. 
شهيد صدر در اين باره دو نظريه دارد؛ برياية نظريه اول ايثان كه در اقتصادنا آمده است، از مناصب ولى امر آن است كه با در نظر كرفتن مصالح و منافع جامعه احكام حكومنى كه يِيشرفت جامعه اسلامى را در يجى داشته

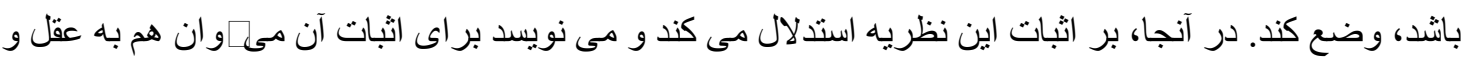

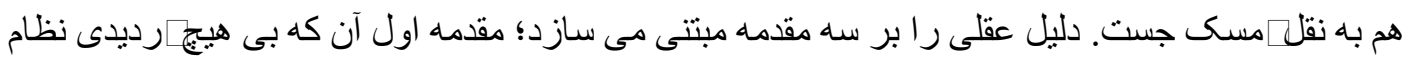

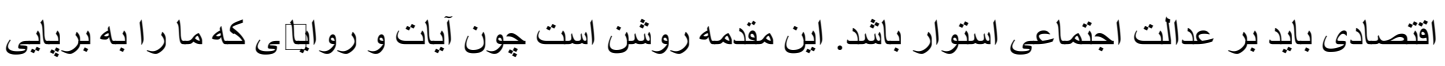
عدالت فر ا مى خو اند فراو ان است ]و نيز حسن عدل و قبح ظلم از مستقلات عقلى است. [ مقدمه دو مآن كه

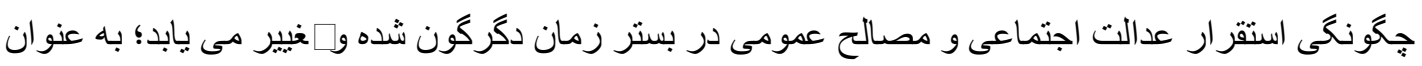

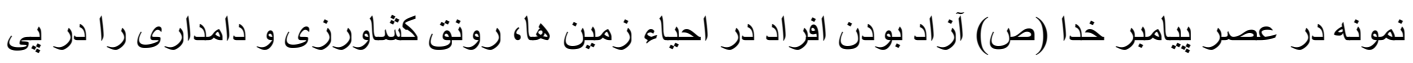

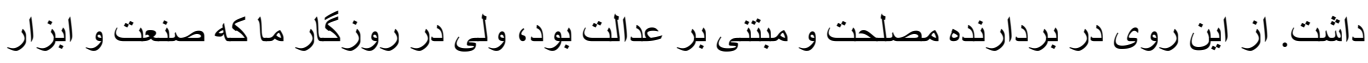

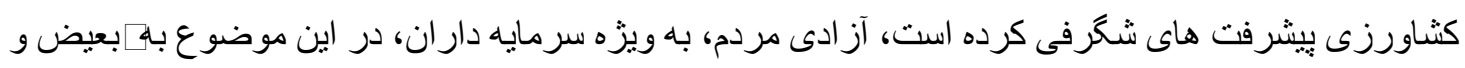
سنمكرى مى انجامد.

مقدمه سوم آن كهمنها راه حفاظت از عدالت اجتماعى و مصالح عمومى آن است كه اين منصب به ولى امر

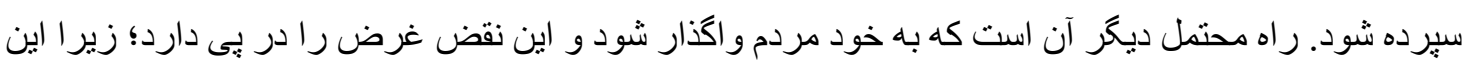
امر موجب اختلال نظام خو اهد شد و هر جند لازم است مردم همه در جهت بر آوردن مصلحت و برديايى عدالت

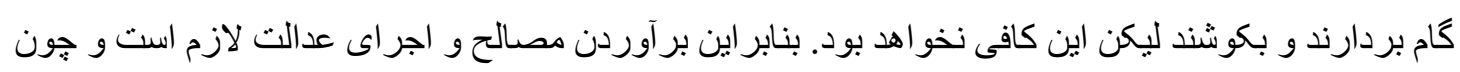

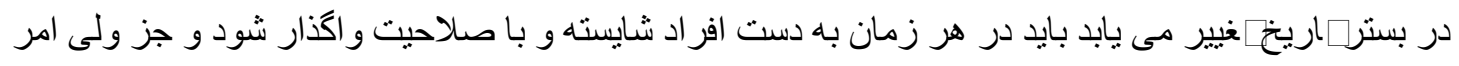

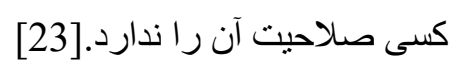

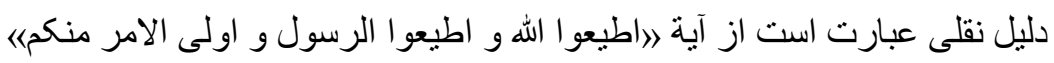

شهيد صدر در استدلال به اين آيه جنين مى نويسد:

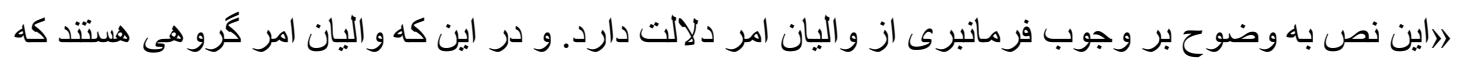

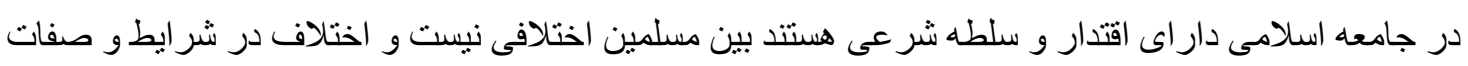

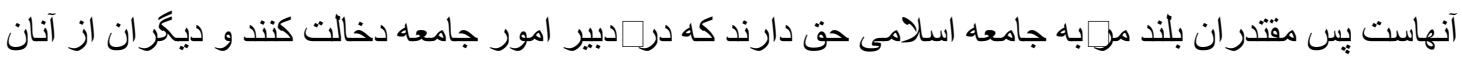

[24]«ت اطن

نظريه دوم ايثان آن است كهَشخيص مصلحت هاو يركردن منطقه الفراغ را بايد به مجلس منتخب مردم، كه از

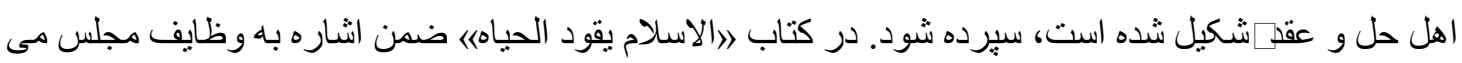

》ادوم آن كه در قلمروى كه شرع مقدس حكم قاطعى؛ يعنى حرمت و وجوب ندارد مجلس منتخب مردم قو انينى را كه به مصلحت مى داند وضع مى كند بدين شرط كه مخالف قانون اساسى نباشد و قلمروى كه قانونكذارى در در آن آز اد است، منطقه الفر اغ ناميده مى شود. و اين منطقه الفر اغ همه حالآى را كه شرع مقدس در آنها موضع معين و حكم خاصى (وجوب و حرمت) ندارد در برمى كيرد. (و همان طور كه يادآور شديم). قو انين مجلس بايد

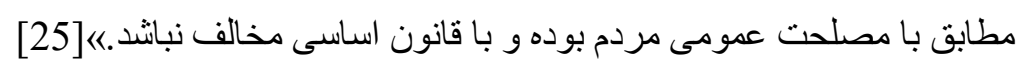
همان طور كه امام خمينى] شخيص مصلحت[26] و صدور احكام حكومتى را از از مناصب و و وظايف ولى فقيه

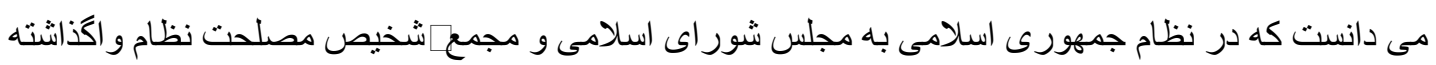


شده است. محتمل است مقصود شهيد صدر در نظريه دوم نيز هين باشد كه در اين فرض با نظريه اول ايشان

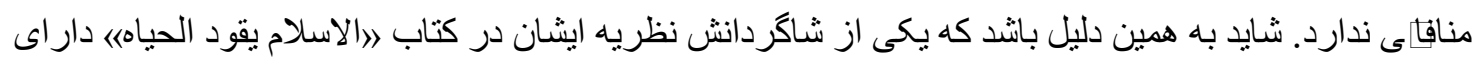
ابهام دانسته است، با اين حال نبايد از نظر دور داشت كه در اثر ياد شده، شهيد صدرطشخيص مصلحت را به به به

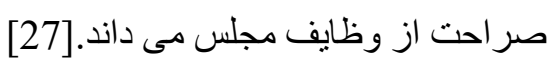
روايات حكومنى

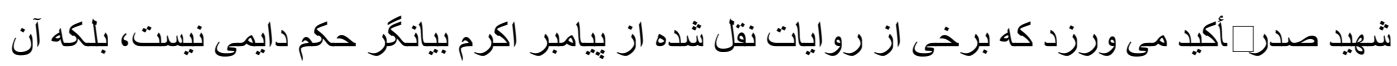

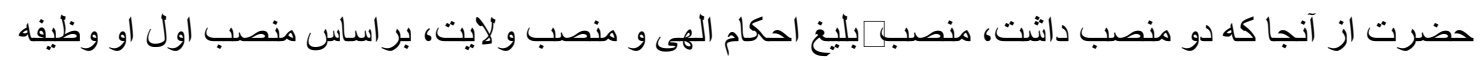
داشت احكام الهى رلـرويج وطبليغ كند و همه سخنان و اعمال او ــا آنجا كه به اين جهت مربوط است - حجت است و بر طبق منصب دوم او مى بايد بر طبق مصلحت، منطقه الفراغ را از احكام ولايى بر مى ساخت و احكام بيامبر خدا در اين باره كم نيست و به هيج يكى از آنها نمى هو ان به عنو ان حجت شرعى استدالال كرده و حكمى از آنها استنباط كرد. [28] نكاهى به نظريه شهيد صدر به لحاظـاريخى همان طور كه آورديم روح اين نظريه و بسيارى از عناصر آن در ديدكاه نائينى آمده است؛

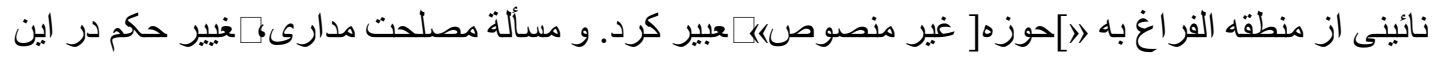

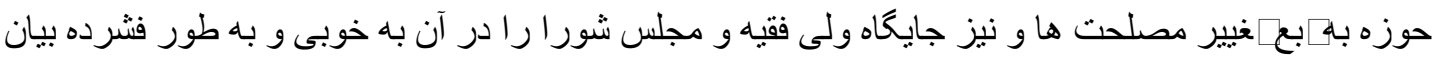
داشت. ليكن شهيد صدر آن را سامان داده و به صورت يك طرح جامع، كسترده و مستدل در آورده است. به نظر مى رسد در نظريه شهيد صدر ابهامات و برسش هايى وجود دارد كه در نظريه منطقه الفراغ باسخ روشنى براى آن نمى لـوان يافت.

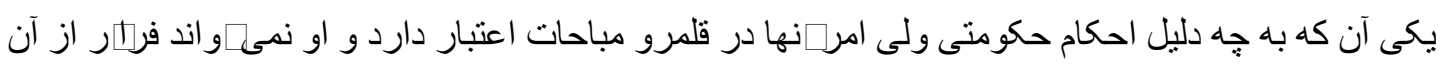
حكمى صادر كند. به ظاهر باسخخ روشن است؛ بدين سان كه در اين محدوده حكم الز امى شرعى نداريم؛ از اين روى هركونه حكم جه ممنو عيت مطلق و جه لزوم مطلق و جه مشروط، مخالف حكم شرعى نخو اهد بود. برخلاف آن كه اكر حكم حكومنى در محدودة واجبات و محرمات باثند؛ سبب مخالفت با حكم خدا خو اهد شد، در جارجوب مباحات جنين نبست. بدين سان اين نظريه برخلاف نظريه امام خمينى كه با اين جالش مواجه بود، از جهت مخالفت با حكم شرعى لن هيج مشكلى ندارد. ليكن به نظر مى رسد اين نتيجه كيرى مبتنى بر يكى نظريه است و آن اين است كهمنها مخالفت احكام و لايبى با وجوب و حرمت مصداق مخالفت با حكم خدا است؛ به عبارت ديكر آن جهه در ميان احكام ينجحانهـ كليفى اهميت دارد و اجب و حر ام است وطنها مخالفت با اين دو حكم است كه مصداق مخالفت با حلال و حرام خداوند است و

ناديده كرفتن مكروه، مستحب و حلال[29] مصداق مخالفت با احكام الهى نيست. مؤيد اين نكته آن است كه

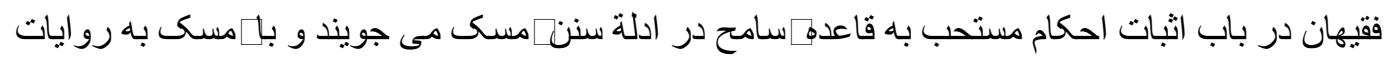
ضعيف، فتو ا به استحباب موضو عى مى دهند. اين نكته كرجهه به ظاهر مسلم و روشن مى نمايد ليكن اثبات آن كار آسانى نيست؛ وقتى خداوند متعال حكمى را

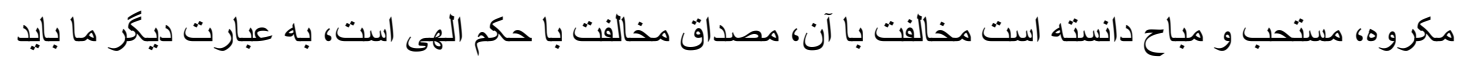


همه احكام الهى را ارج نهيم و حرمت آنهار ا باس داريم و هركاه خداوند متعال بندكان خود را در حكمى آز اد

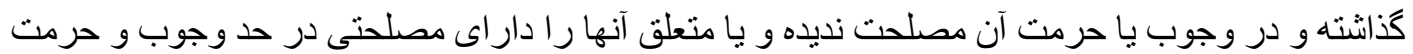

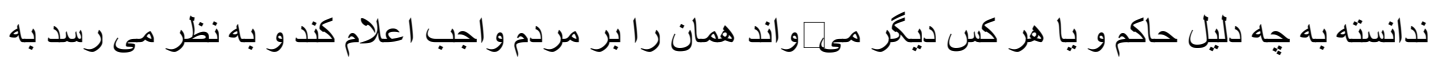

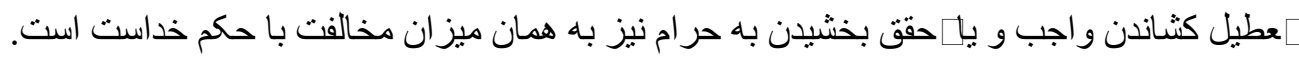

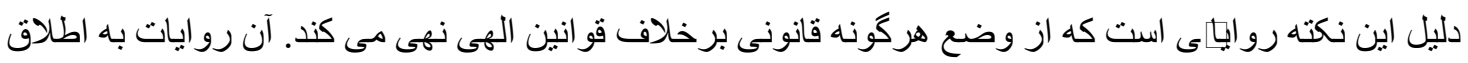

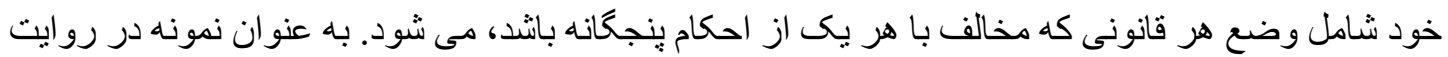
口صف العقول كه شيخ انصارى اثر ارزنده خود، مكاسب را با افتتاح بدان زينت بخشيده دربارة و الى عادلهعبير 》بلازيادة و نقيصة)[30] آمده است. بر طبق اين روايت، همكارى و كارمندى با والى عادل از آن جهت صحيح

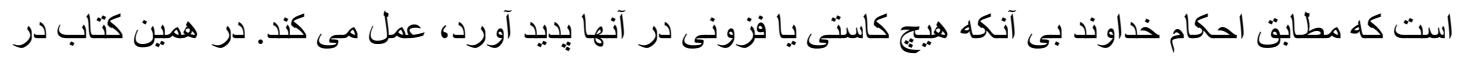

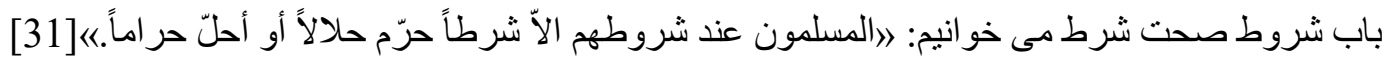
و نيز در همانجا آمده است كه اين مضمون در رو ايات مستفيض بلكه متولار معنوى آمده است كه هركونه

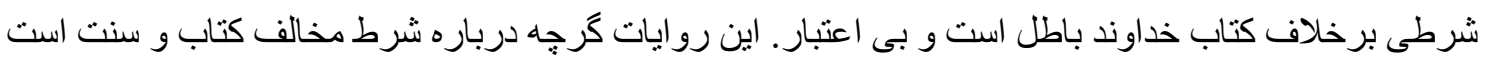
ليكن مى ووان از آنها ملاكى استنباط كردو اصل حلال كردن حرام خداو حر ام كردن حلال خدار را در يكى رديف دانست.

اكر كفته شود مقصود آن است كه نبايد كسى حكمى را كه خداوند حلال كرده، بكويد حر ام است، در احكام حكومنى اين كونه نبست زير ا در آنجا حاكم اسلامى مى داند، اين حكم در اصل مباح بوده و بدان اعتر اف دارد

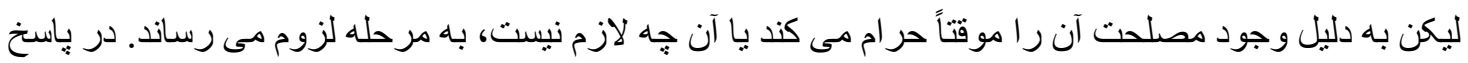
كفته مى شود اين روايات اطلاق دارد و شامل اين حالت مى شود. جه اين كه هر شرط مخالف كتاب خداو نيز

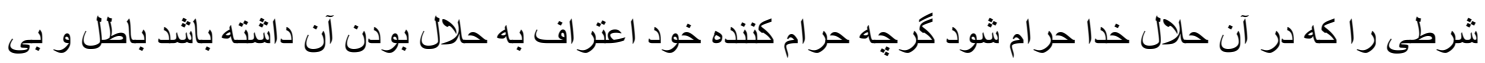
اعتبار است.

به طور خلاصده در قر آن كريم با همان آهنح و لحنى كه از حر ام كردن اشياء سخن مى كويد - به مثل، مى

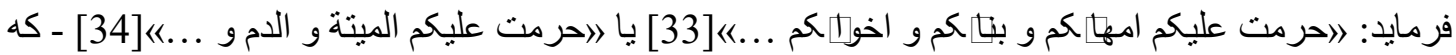

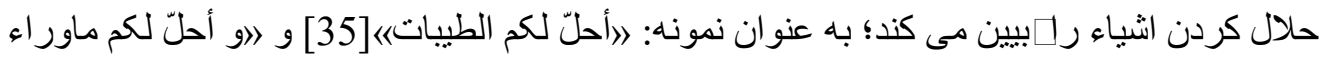
ذالكم ...

بدين سان حلال هاو مباح ها همان ارج، ارزش و قيمنى را دارند كه واجب هاو حرام ها، جهه هر دو از يك

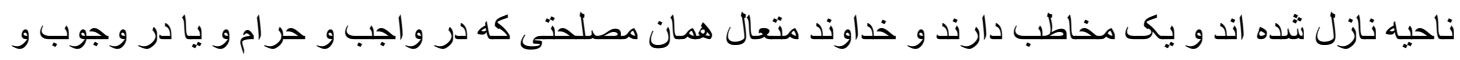
حرمت بوده و به خاطر آن اين حكم الز امى را بدان ها بخثيده و جعل فرموده است. در مباح و يا اباحة اثشياء نيز وجود داشته و با ملاحظه آن اباحه راوضع فرموده است. افزون بر اين كه برخى از آيات قر آن به صر احت از حلال كردن حرام ها نهى مى كند؛ خداوند در قرآن مى فرمايد:

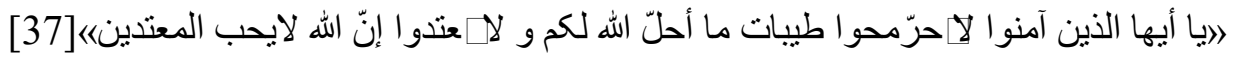

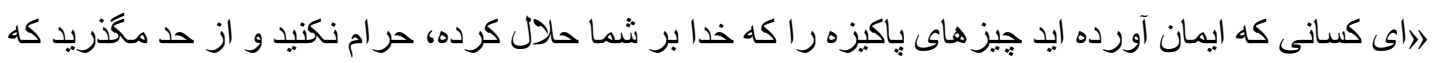

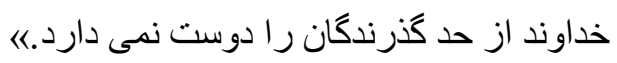


اين آيه شريفه از حرام دانسنن حلال ها را نهى مى كند و آن رل|جاوز به حريم احكام الهى مى شمارد. [38] بدين

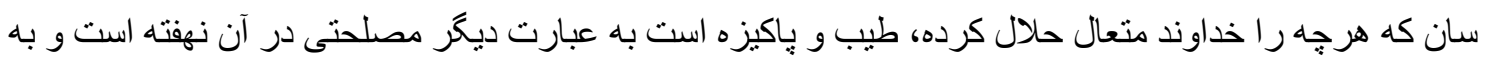
كفته قرآن إيحل لهم الطيبات و يحرم عليهم الخبائث)[39] از اين روى به همان اندازه كه ارلماب حرام انسان را به يليدى ها مى آلايد، اجتناب از امور بِاكيزهو طيب انسان را از سودمندى هاى آنها محروم مى سازد و نيز

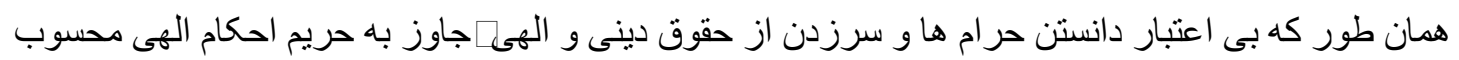

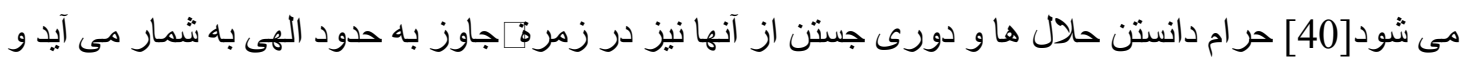

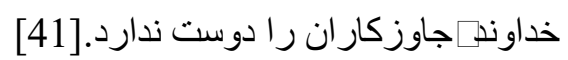
اكر كفته شود در آيه شريفه وازة اطيبات) نشان مى دهد كه اين حكم ويزٔه خور اكى هاو امثال آن است. باسخخ آن

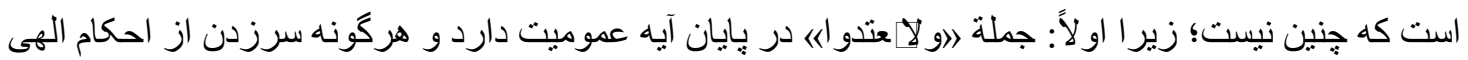

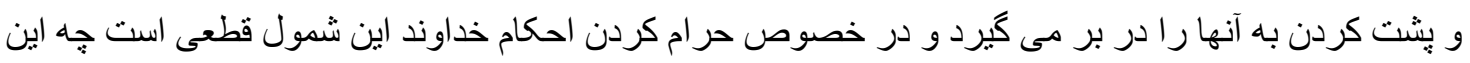

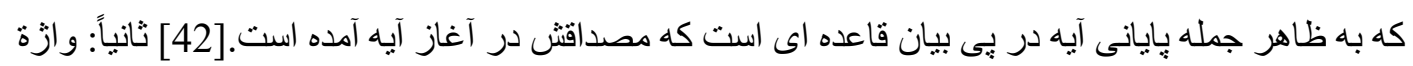

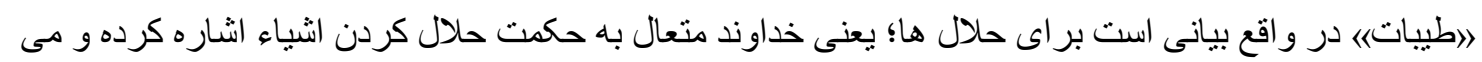

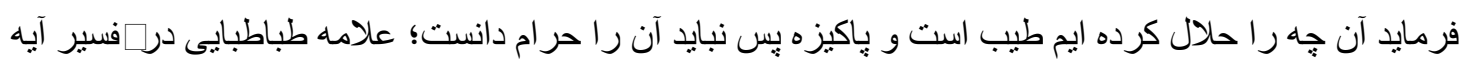
جنين مى نويسد:

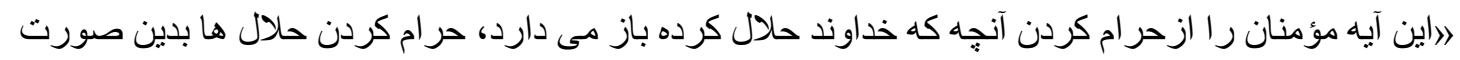

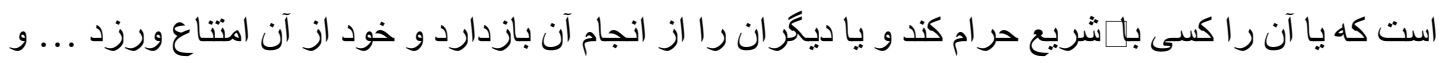

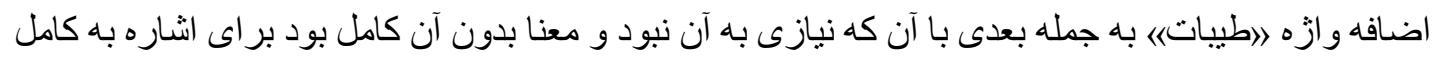

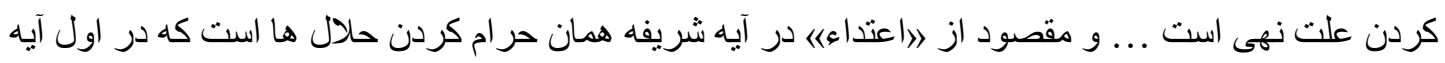

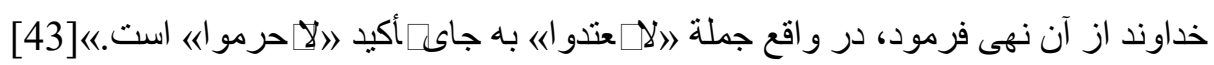
بدين سان بريايه اين آيهو آباىى از اين دست[44] مخالفت با حلال خدا بسبار خطير مى نمايد. و مخالفت با بآن، مخالفت با حكم خدا به شمار مى آيد و از مصاديق روشن مخالفت، آن است كه حكمى از سوى ولى امر يا هر

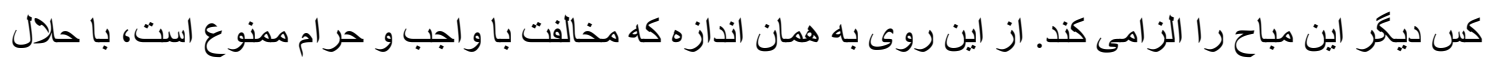

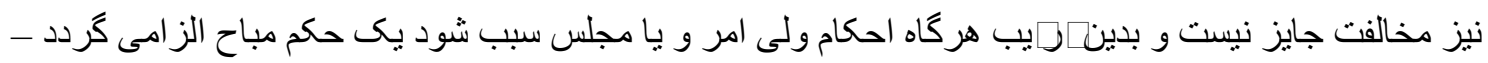
آن گونه كه در منطقه الفر اغ جنين آمده است - در و اقع با يك حكم شر عى مخالفت شده است.

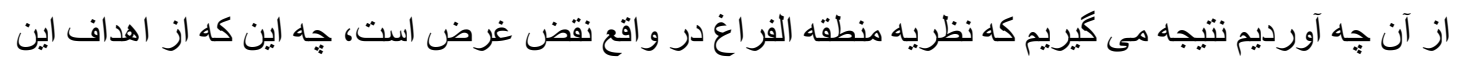

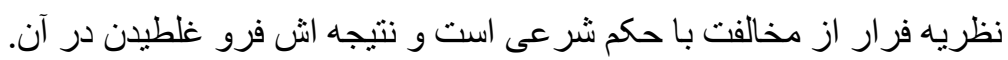

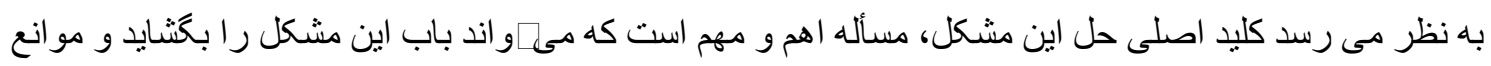
شر عى را از سر راه بردارد. شايان ذكر است كه اين بدان معنا نيست كه از خطير بودن مخالفت با حرام و واجب كاسته شود بلكه آن به قوت خود باقى است. و حساسيت فقهايى جون شهيد صدر در برابر عدم مخالفت با آنها بسى در خور طحسين است.

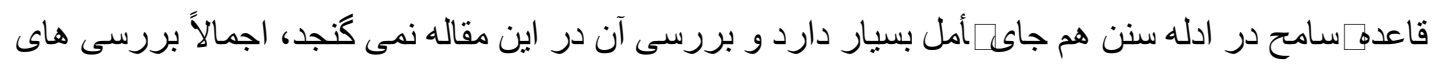

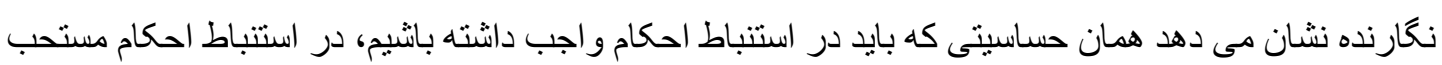


راه شناخت روايات حكومنى نكته بسيار مهمى كه از نظريه منطقه الفر اغ ر اه شناخت روايات حكومنى به جشم مى خورد آن است كه يِامبر

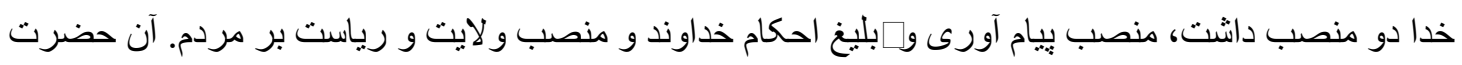

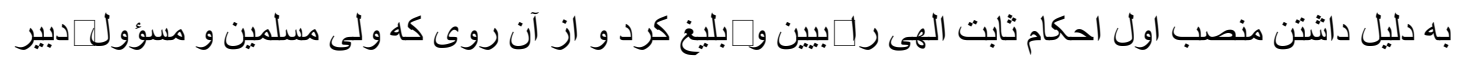
جامعة اسلامى بود و بايد منطقه الفر اغ را با ملاحظه مصالح و منافع جامعه از احكام و لايیى و برخاسته از

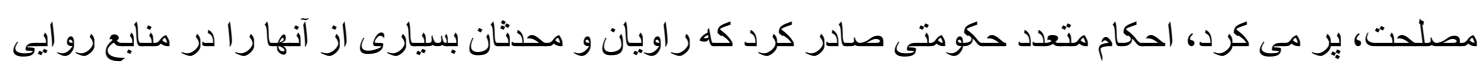

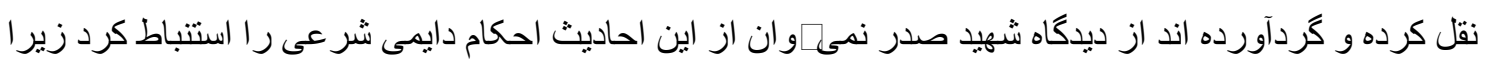

اين روايات ناظر به احكام حكومتى و مصلحتى است كه در زمان هاو مكان هاى مختلف ـغيير مى يابد.

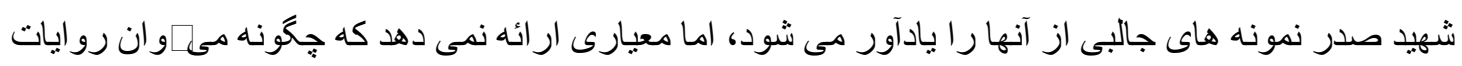

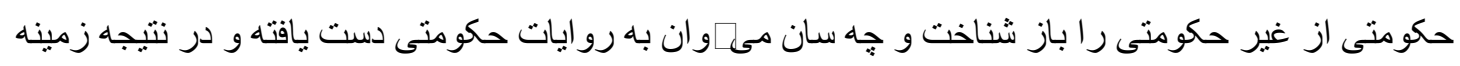

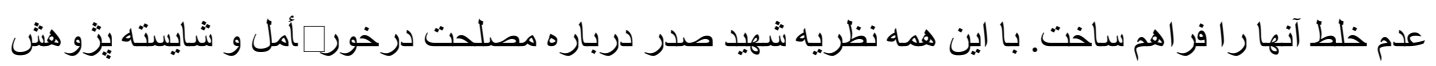
هاى مستقلى است و مى [و اند از برخى زوايا ر اهكثا باتثد.

[1] سيد محمد باقر صدر، اقتصاد برّر، على اكبر سيبويه، [هران، دفتر نشر ميثم، بهـا، ص 169 و نيز سيد

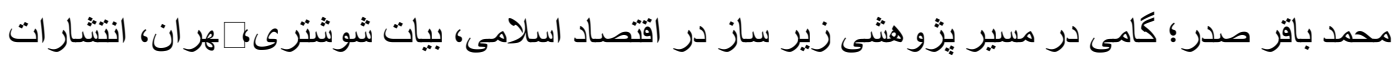
روزبه، 1354 ش، ص 45 و نيز يد محمد باقر صدر. اقتصادانا، بيروت، دار التعارف للمطبو عات، جاب

$$
\begin{aligned}
& \text { شانزدهم، } 1402 \text { ق، ص صن، صن صن } 317 .
\end{aligned}
$$

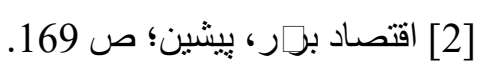

[3] همان طور كه اشاره شد بدون در نظر كرفتن اين مقدمات نظريه منطقه الفر اغ درست فهميده نمى شود و برخى از شاكردان ايشان از خلط اين نظريه با احكام متغير و مسأله زمان و مكان كلايه كرده اند. ر.ك.

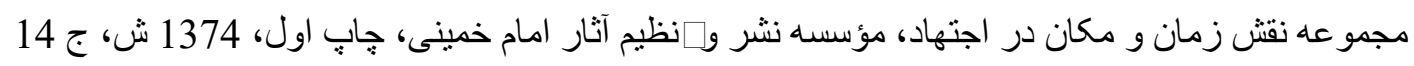

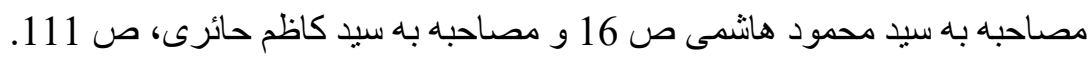

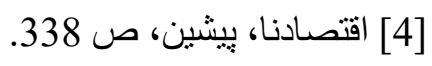
[5]

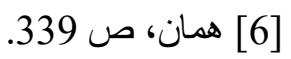
[7] همان، ص 339. و نيز صورة صن عن اقتصاد المجتمع الاسلامى، المجموعة الكاملة لمؤلفات الثهيد محمدباقر

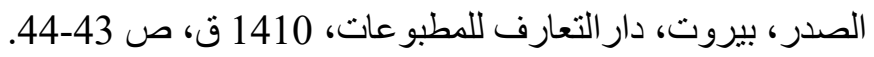
[8] ر.ك: همان و نيز لمحة فقهية مهيدية عن مشروع دسنور الجمهورية اسلامية، جابٍ شده در ضمن المجموعة الكاملة لمؤلفات السيد محمدباقر الصدر (بيروت، دار التعارف للمطبو عات، 1410 ق) ج 12، ص 19.

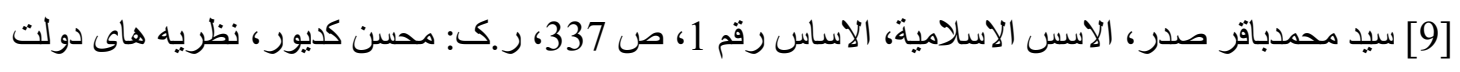

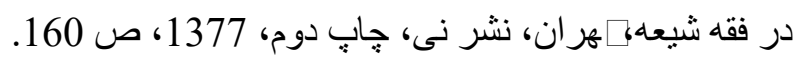
[10] همان. 
[11] شهيد صدر در اقتصادنا (ص 680 - 684) وضع احكام حكومتى را به عهده ولى فقيه مى كذارد و در

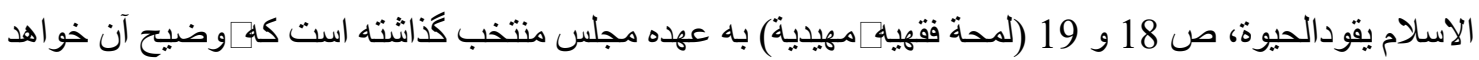

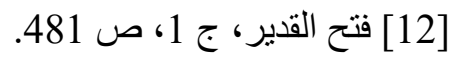

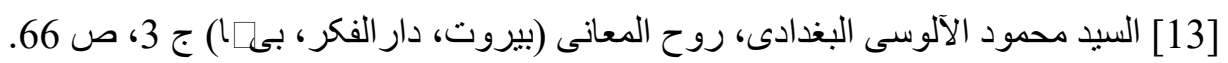

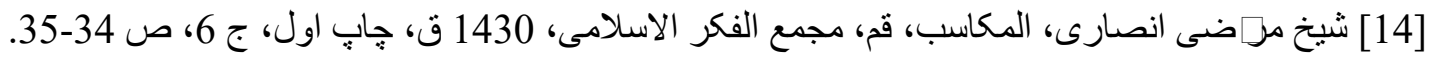

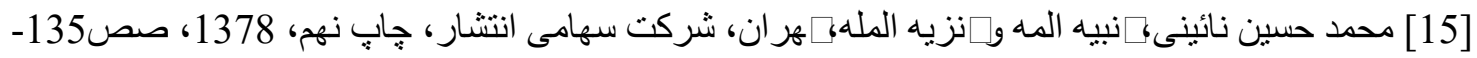

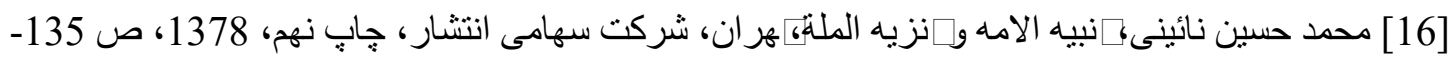

] [17] اقتصادنا، بيشين، ص 726. ] [18] همان، ص 402-400 وص 726 - 725. [19] سيد محمد باقر صدر، الاسلام يقود الحياة، لمحة فقهية معيدية، جاب شده در المجموعة الكاملة لمؤلفات السيد محمدباقر الصدر، بيروت دار التعارف للمطبو عات 1410 ق. ص 18 و 19. و نيز خطوط فصصيلية عن اقتصاد مجنمع الاسلامى، ص 88-79.8 [20] الاسلام يقود الحياة بيشين و صورة] [هصيلية عن اقتصاد المجتمع الاسلامى، جابٍ شده در ضمن المجمو عة

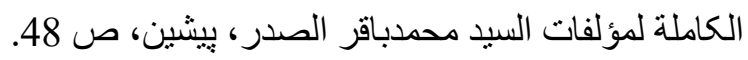
[مان [21] همان، ص 49. [22] [23] صورة]فصيليه عن اقتصاد مجتمع الاسلامى بيشين و اقتصادنا، ص 301. [24] صورة]فصيليه عن اقتصاد مجتمع الاسلامى بيشين و اقتصادا، ص 301 و 527.

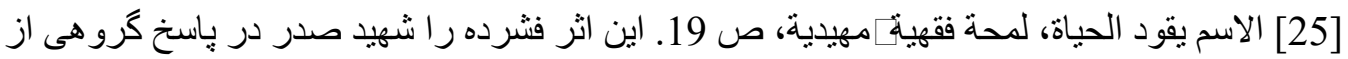
روحانيون لبنان دربارهـبيين اصول و مبانى قانون اساسى و انقلاب اسلامى ايران نحاثتته است. [26] ر.ك: انديشه صادق، شماره 5، نظريه مصلحت از ديدكاه امام خمينى، سيدعلى حسينى. [27] مصاحبه با سيد كاظم حائرى، مجمو عه نقش زمان و مكان در اجتهاد، بيشين، ج 14 ص 111. ] 28 [مان، صص 642، 401، 725 و 726.

[29] شهيد صدر در 》الاسلام يقود الحياة)> (لمحة فقهيه) ص 19 به صر احت مى نويسد: (امقصود از منطقه

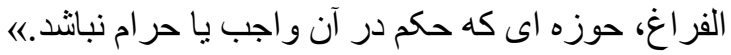

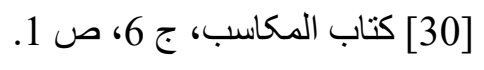

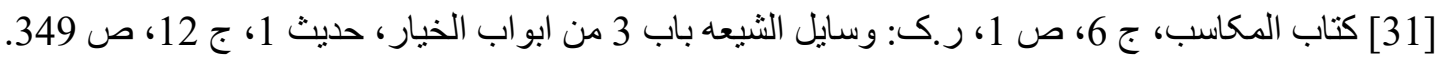

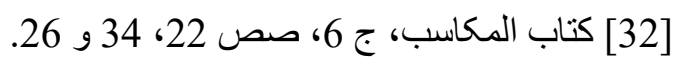
[33] سوره نساء / آيه 23. ] [34] سوره مائده / آيه 3. 


$$
\begin{aligned}
& \text { [35] سوره مائده / آيه } 4 \text { و } 5 .
\end{aligned}
$$

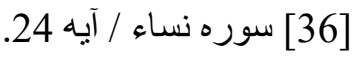

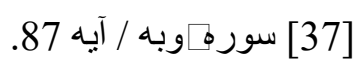

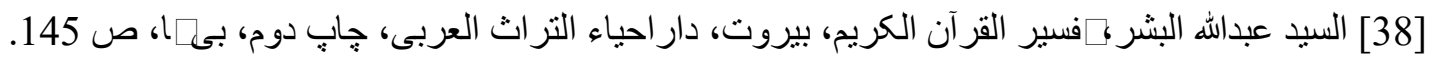

$$
\begin{aligned}
& \text { [39] سوره اعر اف / آيه } 57 . \\
& \text { [40] سوره بقره، آيه 229، سوره نساء، آيه } 114 .
\end{aligned}
$$

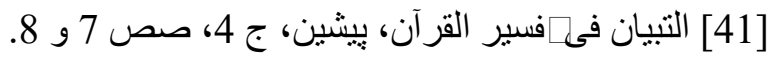

$$
\begin{aligned}
& \text { [42] محمد بن جريرى طبرى به كوشش الدكتور بشار عو اد معروف و عصدام فارس الحرسنانى، [فسير الطبرى } \\
& \text { عن كتابه جامع البيان عنمأويل آى القرآن، بيروت، مؤسسة الوسالة، } 1415 \text { ق، ج 3، صص } \\
& \text { [43] محمد حسين طباطبايى بيشين، (الميزان)، ج 7، ص 105-106. ر.ك: قرطبى بيشين (الجامع الاحكام }
\end{aligned}
$$

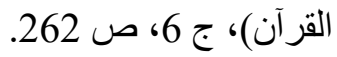

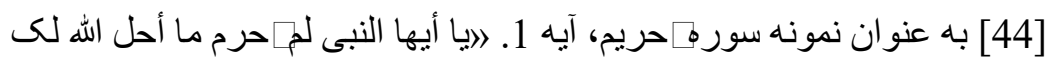

\title{
2-Artigo traduzido publicado em revista iraniana:
}

\begin{abstract}
The martyr Ayatollah " Seyed Mohammad Bagher Sadr" is one of the greatest contemporary sect thinkers and religious scholars who was an expert in different theoretical fields and has published many valuable works. That wise martyr had important and novel theories in various subjects of philosophy, dialectics, methodology, Jurisprudence and economy which those were thinkable and admirable. The theory of " Manteghat ol faragh" or " Vacuum logic" is one of his most significant theories in economy and political Jurisprudence. In this article, beside the review of this theory, its previous backgrounds among sect and Sunni scholars would be discussed. It is necessary to mention that criticizing of the "Vacuum logic" theory does not diminish the value of the theory and its author.
\end{abstract}

\section{Introduction}


The martyr Seyed Mohammad Sadr is one of the most prominent sect contemporary scholars and jurists who had deep knowledge of diverse Islamic sciences. He had been a sage and time wise jurist who had been trying to declare the Islam's viewpoint in different fields logically and proportionately to the time. He had some novel and important theories in some issues of Dialectics, methodology, , Jurisprudence and economy.

The "Vacuum logic" theory is in the efficient and key category of Sadr's viewpoint. That is the center of attention among researchers due to its role in the political Jurisprudence, economy and the importance of time and location in Ijtihad and diligence. This paper's aim is to review and criticize the " Mantegh ol Faragh" theory and its relation with the governmental rulings and the benefit of report. In order to learn about the theory, it is useful to pay attention to the following tips:

\section{Universality and collectivity of Islam:}

Sadr believes that Islam is a kind of religion which covers all aspects of man's life and provides a comprehensive plan so as to how to live better. He writes : $<<$ one of the important traits of the Islam is being in line with all aspects of human life. This uniformity is not only achieved in establishment the Islam and searching in its rulings but also, it can be found in Islamic heads and resources. $>>$ [1]

Thus, The Islam is a wide-ranging religion and according to what Imam Sadegh has said, there can be found rulings for whatever you may face in your life. [2]

\section{Fixed and variable rulings [3]}

Human needs have made him search for a social life. Therefore, in this way he is searching to satisfy his needs and they would not be achieved except in a society. Hence, he turns face to the group life. Sadr says:

$<$ Human is designed in a way that he has an intrinsic plea to gratify his needs. Accordingly, he needs to get the others help since this is the only way to achieve his needs and aims. Therefore, social relations have been originated from human needs and it would 
be developed by the needs' expansion and that is why the human social life comes from human needs. $>>$

Human needs are divided into two groups: fixed and variable needs. Fixed needs are those which called essential and vital needs enable human to survive such as water, air and oxygen, breeding etc. that are common among all people.Variable needs are a group of needs which arise gradually in life. The more someone is experienced and knowledgeable, the more these needs would be extended. Thus, fundamental needs are fixed and non-essential needs are variable and unfixed.

As a result, as human has fixed and variable needs, those social and economic systems are successful which have the capability of satisfying both fixed and variable needs. Accordingly, social and economic systems not only have fixed principles but also variable ones. It should be mentioned, that is harmful if there are all fixed or all variable.

The master Sadr believes that the Islam has wisely divided its rulings into fixed and variable principles. Hence, those are not totally fixed or totally variable. Some parts of them are fixed and the other parts are proportionate to the alteration and changes in situations and status. As a matter of fact, fixed rulings in Islam are the answers to human needs and it shows how to comprehensively achieve these responses to illustrate, some needs such as man's livelihood guarantee, the right of using earned wealth from job, acquiring essential generation survival conditions, criminal and financial safety, the relation with and dependence to an absolute creature are considered as fixed and basic needs.

So as to gratify these needs, Islam has some rulings such wealth distribution, marriage and divorce, punishment rulings and a slavery system. On the other hand, there are some variable rulings which are in a constant adjustment and change. These rulings would be adjusted by the Islamic supreme leader according to the benefit of Islamic society.

\section{3-The jurist leadership and Islamic government}

One of the Sadr's theory traits is that he believes there is a high correlation between benefit and leadership. He is one the jurists who had a particular belief in Islamic government and dedicated his life to prosper in Iraq.Here is not somewhere to compare 
Sadr's view point with Imam Khomeyni one's and it is to mention that firstly: he believed in Islamic government and secondly: he believed in a close correlation between leadership and benefit. He used to repeat frequently that governing rulings or variable rulings issued from the supreme leader is according to the benefit and to gain justice. Hence, we can consider the goodness or benefit an issue of leadership and government.

\section{4-The goodness, as government rulings formula or criterion}

The result of reminded introductions is that Islam is a comprehensive religion for this world and other world and it has plans for people's livelihood and spirituality. That's why Islam has fixed and variable rulings. People's basic needs would be satisfied by fixed rules and the government plays a major role in determining these rules and the supreme leader has to legislate these rules paying attention to the goodness and great religious objectives such as justice. Hence, the goodness is the basis of governing rulings. This opinion has been pointed in Sadr's various works. Here there are some examples of his viewpoint:

The Martyr Sadr writes :

$<<$ the structure of selective government and governmental organizations should have the highest coordination with the Islam's goodness and benefit and in fact, by considering that, the government and its related organizations would be determined.>> [9]

After choosing the government, the government should decide up to Muslims' benefits whether worldly or spiritually. [10] Therefore, Sadr believed that the chosen government by the Islamic society should consider the benefits in order to manage the society. In another section he expresses that since the government should work in an Islamic framework and whenever jurists have different opinions in their judgments, the leader or the chosen parliaments should decide what the best is for the Islamic society even if that is in contrary to the qualified jurist for leadership of the system..Thus, it is obviously seen that Sadr believes in benefit as the basis of government rulings.

\section{5-The "Mantegh OI Faragh" theory backgrounds}


It is quoted from many Sunni jurists that Imam Malek is the originator of the "Masaleh Morsale" theory and the follower jurists faced some challenges using that theory. The most important challenge was the conflict between the rulings derived from it and religious principles. The proposed solution to such a problem was that they expressed : the "Masaleh Morsale" should not be in contrary to religion and its reasons.

Some Sunni commentators faced a problem when translating the word "Olel Amr" and the problem is that if the reference of mentioned word is the Imam, Kings, Judges and whoever has the religious authority, then what should be done when their rulings are different from religious principles? And if we cannot prioritize their ideas above God's order- which undoubtedly we cannot- what should be done so as to solve the problem obedience to God or others-?

In reply to the mentioned question, Shukani and Alusi believe that the obedience to governors is acceptable only when they work in religion framework. There are lots of different opinions; some believe in authority for the leader, some groups think it would be acceptable if compatible with the public benefit. Besides considering the above points, Alusi emphasizes on not obeying the conflicting rulings. He states that:

$<<$ Does necessity of not obeying cover the permissible rulings territory? There are lots of differences in opinions. Some have said it is not obligatory to obey since no one is permitted to prohibit what is allowed by God and some have said it is also obligatory to obey in permissible rulings field. Haskfi is one of those who have explicitly stated the last provision. Some of Shafei researchers have also stated, it is acceptable to obey the Imam while is in religious framework and some others have said, whenever the Imam's order is not originated from public benefit, obeying is not obligatory inwardly, but if yes, obeying is obligatory inwardly and outwardly.[13]

In Alusi speeches, the obligation of obeying to Imam in permissible items territory has been pointed ambiguously, turbulently and exclusively. He has not been able to conclude from past scientists and get an explicit result.

Among Sect jurists, Sheikh Ansari has some subject matters of provisions that can be considered as a hint for "Mantegh Ol Faragh" theory. There have been pointed to some jurists' opinions that according to some narrators every single provision which is against 
the religion would be prohibited. When it comes to this issue, Sheikh brings an important question up: ((what makes permissible change into prohibited and vice versa?)) to illustrate, what we call if someone avows to do beneficence or quit doing that, legit or unlawful? Is it prohibiting the legit or obligating the inessential?

In response to that question Sheikh answers: prohibiting the legit and making the prohibited free or allowed happens when someone contributes a sentence to God's religion and make the religion laws become altered or changed. Therefore, if a father orders to his son that he should quit something evil or starts something beneficent, this is normal since obeying to fathers is what is God has ordered. It should be mentioned that father is not allowed to ask his children so as to quit something unlawful or commit it[14]. Indeed, Sadr has expressed exactly the same issue about the obligation and necessity of obeying to leader.

\section{6-"Mantegh Ol Faragh" theory in Naeini's speeches}

Naeini in his book named "Tanbih ol aeme va tanzih ol mellat" emphasizes on a point that the parliaments' and government's rules must be authoritative in religion scope and this is the scope which has been assigned to jurists in the absence time of Imam so as to make laws and rules.it is valid to consult with experts in Islamic parliaments about the mentioned scope not for authoritative rules. As a matter of fact, jurists are responsible of taking the rules out of religious issues and the parliament's members are there to have them affirmed. In line with this issue he states:

$<<$ All of the duties related to discipline and preservation of the country and the policy of people's lives whether they are original or typical, have been classified into two major groups: firstly, those which are written directly in religion and secondly, those which should be interpreted of religious rules. $>>$

That is axiomatic that the first group is fixed upon ages while the second one is related to whom he interprets them. The interpretation of these rules is up to the God's envoy and his representatives in time of absence. Therefore, first of all, it is the God's envoy duty to explain religion rules, then it goes to his representatives.

Deceased Naeini conclude a five class result: 
1- It is necessary to adjust the country rules to the religion. The purpose is to match the first group rules. There is no meaning to conform the second group rules.

2- Consultation is only going in second group.

3- Requirements to second group rules are up to God' innocent envoys, whereas up to their representatives in the time of absence.

4- The majority of politics and what is related back to government would be covered by second group.

5- It is necessary to obey the goodness in second group rules and in fact, here is the domain of variable rules. As Naeini says:

$<<$ as it is mentioned before, the second group of rules is from typical politics and not written in religion directly. These kinds of rules are not fixed at all. They are exposed to change by passage of the time and occasions. $>>$

\section{7-The burgeon of Mantegh ol Feragh theory}

Many of elements in the Sadr's theory are in line with what Naeini Has already said and actually those have been completed, organized and improved wisely by Sadr. After considering the goodness a basis for governing rules, Sadr states that the guardian should codify the government rules under the coverage of great religion goals made of fixed rules according to what is the best for the society. These rules have a specific domain and that is somewhere with no obligatory or forbidden rule. In such a framework which he calls it the open area and vacant of necessary rules, the variable rules would be derived by the guardian according to the society's benefit. This mentioned area is just vacant of necessary provisions, not other kinds. It should be mentioned here that no aspect of life is been left without a rule determined by the religion.

Sadr emphasizes on the point that his theory is not a defect and the illusion that states Islam has only prescribed rules to some issues is meaningless. As a matter of fact, 
this theory is a domain containing permissible rules. Mantegh Ol Feragh is the symbol of a dynamic Islamic thinking in response to all problems of mankind of every generation and presents a method which enables Islam to gratify all what human needs whether fixed or variable.

It should be mentioned that the most descriptive explanation on political issues can be found in the book named "our economy" while Sadr in some of his works contributes and expands it to all social, political, financial and every kind of public rule.

Besides emphasis on not contradicting with religious rules, Sadr adds another point which states that variable rules should be interpreted under the coverage of fixed ones. The holy lawyer not also broaches the fixed rules but also he provides the significant aims which should be achieved in the society. The variable rules should be organized by the leader or government and parliament in a way which makes the fixed rules become implemented. To illustrate, besides pointing in the Fiei verse to a permanent rule, God mentions a significant goal which states that not a specific group are allowed to take over the majority of wealth and properties. The wealth should be shared among people proportionately.

Different narrations related to zakat (an Islamic financial help given to poor people) vividly depicts that Islam is not seeking to satiate poor people as much. The main aim of what is called zakat is to diminish the social caste differentiation and difference. This helps all people obtain what is suitable to their aptitude.

Some of Quran's verses also states that values such as justice, equity and motivating brother ship among abstemious people is one of the most important objectives of Islam. Hence, the leader should assess people's benefit in determining the variable rules. According to Sadr's speeches, the leader firstly, should make his provisions based on benefits in the vacant area and secondly, these benefits and the derived rules based on them should be interpreted and done under the coverage of fixed rules.

\section{8-Benefit Recognition reference}

As mentioned before, filling the vacant area is to satisfy society variable needs and government by the holy lawyer. As pointed, this duty is carried by the prophet and Imam in the time of presence. They are the only valid references that are eligible to establish the true Islamic government and this important burden will be done by the leader 
or parliaments in the absence period. In this section we are going to answer this question more precisely:

Sadr has two theories on this field. On basis of the first theory which has been brought in the book named "our economy", it is the leader's burdens to legislate the rules which make a benefit for society and its development. On proving this theory, Sadr states that we can refer to the wisdom or narrations. He based the rational reason on three introductions; the first one states that the economic system should categorically be based on social fairness. This is axiomatic due to copious verses in religion and narrations. This is also an intrinsic issue believed that justice is good and oppression is considered bad. The second introduction implies that how social fairness and public benefit would get changed during the years. To illustrate, in the prophet's era, being free and land vitalization were the results. Hence, the second one contains the public benefit and is based on justice but, by the advance of agriculture and industrialization in our era, the people freedom particularly capitalists would create discrimination and oppression.

Finally, the third intro states that the only way to protect the public benefit and fairness is to entrust it to the leader. There is another probable way which states that it should be entrusted to people. Entrusting to people has some disadvantages. it would disrupt the total discipline. Although it is necessary to have the help of every individual members of a society, that's not sufficient. Thus, fulfilling and implementing the justice is vital and as it changes, it should be revised by an eligible person and the holy leader is the only eligible person.

\section{9-The narrative reason is the verse below:}

$<<$ Obey to Allah and his prophet and his representatives. $>>$

Sadr on reasoning to this verse states that:

$<<$ This statement is explicitly indicates on the indispensability of following the leaders. There is no doubt on that the leaders in an Islamic society are those who have the authority and religious acceptance. The only difference among them is their characteristics and conditions. Hence, the top authoritarians in the society have the right to interposition in managing the society issues and others must obey to them.>> 
Now we come to the second theory of Sadr. The second one talks about the benefit recognition which should be passed to the selected parliaments. This parliament is consisted of the public representatives those who are familiar with solving and taking things out. In in the book "the Islam, the flag of life, besides pointing to the parliament's duties, Sadr writes:

$<<$ The parliament legislate the rules in the fields which are not defined in religion. The area which the legislator is free in is called the vacant area. This vacant area covers all aspects which do not have been asserted straightly in religion. As it is mentioned before, the rules made by the parliaments should be according to the public benefit. They shouldn't be in contrary to the fundamental rules. $>>$

As Imam Khomeyni considers the benefit recognition and issuance of governing rules the holy leader's duty, he initiated the benefit recognition convention in Islamic republic in Iran. Likely that's the Sadr's purpose on the second theory. Thereby, there is no contradiction between the first and second theory. That is why one of his students thinks that his theory in his book "The Islam, Flag of life" is vague. However, that is not so far that in the mentioned work, Sadr believes in benefit recognition as a major duty of related convention.

\section{Government narrations}

Sadr emphasizes that some of the prophet narrations are not persistent rules. As the prophet had two burdens, one related to advertising religion and another related to leadership, according to the first one he had to advertise the celestial religion and on this way each of his behaviors and words is a must. According to the second burden, he had to take out the benefit-oriented rules from the religion and he did but there shouldn't be referenced as a religious point and no rule is allowed to be extracted from them.

\section{A look at Sadr's theory}


Historically as mentioned before, the spirit of this theory and many of its elements has been pointed in Naeini's viewpoint. Naeini has interpreted the vacant area as the not-written field and the benefit-oriented issue, changes of rules in this field and consequentially changes of benefits and also the position of the supreme leader and parliament have been mentioned compactly. What is to be said here is that Sadr has organized these issues and has broached them as a comprehensive, casual pattern.

It seems there are questions and ambiguities in the Sadr's theory which have been remained unanswered explicitly in vacant area theory. One is that why the supreme leader is allowed in permissible issues without being able to rule out beyond that. It is apparently obvious that we do not have a religious must in this field. Hence, every kind of rule is not considered contradictory to religious rules. Despite of opposing God's order in obligations and unlawful issues field, in permissible filed is not like that.

Therefore, unlike to Imam Khomeyni's theory which is faced with such a challenge, this theory does not have any problem regarding opposing to religious rules. It seems this conclusion is based on a theory which states that only those kinds of rules that are against obligation and taboo issues are examples of opposing with God. In other words, among assigned provisions there are only obligated rules and taboo issues which should be observed and ignoring other kinds of provisions such as detestable, recommended and permissible is not considered contrary to God's order. The confirming reason is that jurists use the tolerance principle in traditions' reasoning in order to prove recommended rules and regarding to some faint narrations, they issue Fatwa so as to make a subject obligatory.

Although this is an obvious point, that is not easy to prove it. When God has ordered to a rule to be recommended, detestable or permeated, we should observe it as he wishes and whenever he has made us free in a provision or has made some borders on it, why could the leader or others change its status? Isn't it the example of opposing with God's order? Of course yes it is.

The reason for this point is those narrations which prohibits us from legislation any rule against the God ones. Those narrations cover every kind of rule which states opposition with mentioned five groups of rules. To illustrate, in 'Tohaf Ol Oghul" narration which is been used by Sheikh Ansari in his book, the righteous governor is been interpreted as "without missing". According to this narration, cooperation with the righteous leader is correct since he operates as god ordered without any missing. In 
Ansari's book named "Makaseb" it is stated that Muslims are not allowed to make a permeated rule prohibited and vice versa.

It is also mentioned there, this concept has been pointed in supersensible narrations that every kind of term against the God's order is not valid. Although these narrations talk about contraries to God's book and tradition, by eliciting a criterion we can consider prohibiting what God has permeated or vice versa attaining the same grade.

If it is said that no one is allowed to prohibit what god has allowed, that doesn't go true in government rules. The reason for this matter is that the Islamic leader knows that such rule is indeed allowed admitting it, but according to the existence of benefit he would make it temporarily prohibited or make something needed which is not vital at the time. It would be stated in response that these narrations have predication covering this term. Therefore, despite the author admission, each term in contrary to God's book and his orders is void.

\section{Briefly, in Quran there is one tone used for both prohibiting things and making things free.}

Hence, permissible issues have the same value as taboos and obligations. The reason for this matter is that their source and target is the same and they cover similar benefits for their targets. In addition in some verses, making taboos free is explicitly mentioned as not allowed issues. God in Quran says:

$<<$ Do not make taboo what is kosher for you and do not heresy that God doesn't like heretics. $>>$

This holly verse considers the making koshers taboo as invasion of God's policy. Therefore, whatever that God has made legitimate is clean and neat. In other words, there is a benefit concealed in it. Hence, as having taboos makes human dirty, avoiding koshers also makes him deprived of their benefits and also as considering taboos invalid is a kind of invasion of God's policy, the prohibition of koshers is also known as invasion in which God doesn't like invaders.

It should be stated here that the word Tayebat (koshers) in the mentioned verse is not only used for edibles. The reason for this matter is that firstly, "do not heresy" at the end of the sentence is general and covers every kind of violation of God's orders and this 
is also definite about prohibiting legitimates. Indeed the last part of the verse is going to state a rule which its example has become in the beginning. Secondly, the word "Tayebat" (koshers) is the symbol of koshers. Actually, God points to the reason of making things legitimate and states the neatness of what has been become kosher and they shouldn't be considered taboo.

\section{Allame TabaTabayi- the Islamic scientist interprets the mentioned verse as this:}

$<<$ this verse prevents the believers from prohibiting what is legitimate. Prohibiting legitimates is done in two ways; whether using religion making them forbidden or preventing others from doing. Despite the thorough meaning of the whole sentence, adding the word "Tayebat" or koshers is to complete the reason of interdiction. Furthermore, the reason of expressing the concept "violation" is to prohibit making koshers taboo.

Accordingly, on the basis of such verses, opposition to God's legitimate is seriously prohibited and opposition to that is opposition to what God has ordered. The axiomatic example of such opposition is that the supreme leader prohibits a kosher. Therefore, opposition is not allowed whether to the taboos or permissible issues. To sum up, whenever the supreme leader or parliament made a kosher banned, as it is stated in vacant area theory, there have been opposed to a religious rule.

According to what is discussed above, we conclude that the vacant area theory is actually the violation of purpose. One of its goals is evading the opposition to religious rules and its result is to suffocate in it. It seems the major key to solve such a problem is the issue of what's more important which would solve this problem and remove the religious barriers.

It should be mentioned, this does not mean that the above discussion degrade the importance of opposition to taboos or obligations and sensibility of jurists such as Sadr to not to oppose to them is admirable.

The tolerance rule in Sunni reasoning is broached many times which is not in the scheme of this paper. In short, the author's investigations show that comprehension sensibility of recommended rules should be the same as obligatory rules. 


\section{Recognition of government narrations}

The important point in which vacant area theory considers it as a way to recognize government narrations is that the Islam prophet had two posts; firstly the duty of being prophet expanding God's religion and secondly the duty of leadership and guidance. He used to advertise fixed rules due to his first duty and as he was the Muslims leader, he had to fill the vacant area with the benefits of society which were government rules. These rules have been referred in many references. In Sadr's perspective, fixed rules could not be taken out of such narrations since these rules have been made according to what is better for a society which may be changed by the passage of the time and alteration of the location.

Although Sadr brings some of those as interesting examples, he does not provide a suitable criterion so as to distinguish the types of rules having them discriminated and consequently separated. Anyway, the Sadr's theory is one of the most eligible and notable theories which can be used as a key to open some locks in some angels. 